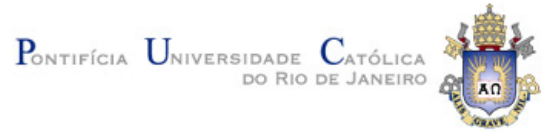

Rodrigo Pinto de Brito

Da Coerência Pragmática da Dýnamis Cética em uma Perspectiva Dialética

Tese de Doutorado

Tese apresentada como requisito parcial para obtenção do grau de Doutor pelo Programa de PósGraduação em Filosofia da PUC-Rio.

Orientador: Prof. Danilo Marcondes de Souza Filho

Rio de Janeiro

Abril de 2013 
Rodrigo Pinto de Brito

\section{Da Coerência Pragmática da Dýnamis Cética em uma Perspectiva Dialética}

Tese apresentada como requisito parcial para obtenção do grau de Doutor pelo Programa de Pós-Graduação em Filosofia do Departamento de Filosofia da PÚC-Rio. Aprovada pela Comissão Examinadora abaixo assinada.

Prof. Danilo Marcondes de Souza Filho

Orientador

Departamento de Filosofia - PUC-Rio

Profa. Vera Cristina Gonçalves de Andrade Bueno

Departamento de Filosofia - PUC-Rio

Profa. Irley Fernades Franco

Departamento de Filosofia - PUC-Rio

Prof. Aldo Lopes Dinucci

UFS

Prof. Marcus Reis Pinheiro

UFF

Profa. Denise Berruezo Portinari

Coordenadora Setorial do Centro de Teologia e

Ciências Humanas - PUC-Rio

Rio de Janeiro, 12 de abril de 2013 
Todos os direitos reservados. É proibida a reprodução total ou parcial do trabalho sem autorização da universidade, do autor e do orientador.

\section{Rodrigo Pinto de Brito}

Graduou-se em Filosofia (Licenciatura e Bacharelado) na Universidade Estadual do Rio de Janeiro (UERJ) em 2006. Concluiu o Mestrado em Filosofia na Pontifícia Universidade Católica do Rio de Janeiro (PUC-Rio) em 2010. Atuava como Professor Assistente Temporário na Universidade Federal Fluminense (UFF) e Professor Docente I na Seeduc quando da defesa da presente Tese de Doutoramento.

Ficha Catalográfica

Brito, Rodrigo Pinto de

Da Coerência Pragmática da Dýnamis Cética em uma Perspectiva Dialética / Rodrigo Pinto de Brito; orientador: Danilo Marcondes de Souza Filho. - Rio de Janeiro PUC, Departamento de Filosofia, 2013.

213 f. ; $29,7 \mathrm{~cm}$

1. Tese (doutorado) - Pontifícia Universidade Católica do Rio de Janeiro, Departamento de Filosofia.

Inclui referências bibliográficas.

1. Filosofia - Teses. 2. Ceticismos Antigos. 3. Sexto Empírico. 4. Apraxía. 5. 'Contra os Retóricos'. I. Marcondes, Danilo (Danilo Marcondes). II. Pontifícia Universidade Católica do Rio de Janeiro. Departamento de Filosofia. III. Título. 
À minha família e amigos, cujo apoio foi fundamental.

Ao Professor Danilo Marcondes, mais do que um orientador, um inspirador. Aos meus filhos, e especialmente à minha esposa Tatiana: o alicerce sem o qual nada disso seria possível. 


\section{Agradecimentos}

À PUC-Rio agradeço aos auxílios concedidos, sem os quais este trabalho não poderia ter sido realizado.

Se realmente esse trabalho foi empreendido de forma dialética, ou dialógica, nada mais justo do que agradecer aqui aos interlocutores.

$\mathrm{Na}$ época da Graduação fui contagiado pelas pesquisas sobre ceticismo dos Profs. Marcelo Araújo e Luiz Bicca, ambos da UERJ. Com o primeiro troquei artigos, o segundo vem participando ativamente de todas as etapas dessa pesquisa.

$\mathrm{Na}$ mesma época e Universidade tive o prazer de tornar-me amigo de Régis Bahia, Cesar Kiraly, Mohandas Souza, Rafael Huguenin, Alexandre Skvirsky, Rogério Soares e Daniel Rodrigues. Com o primeiro troco impressões sobre a vida, trabalho e família; com o segundo estreitei os laços ao me tornar professor da UFF, culminado com a realização de um congresso, a publicação de diversos artigos e a criação de um grupo de estudos sobre ceticismo; com o terceiro compartilhei acesso a bases de dados e artigos; Rafael Huguenin é um parceiro imprescindível para essa pesquisa e sua importância não pode ser medida aqui. Com Alexandre e Rogério dividi a autoria de importantes traduções, e deles recebi doações de uma vasta bibliografia. O humor cáustico do Daniel me ajudou a suportar o cansaço.

Fui acolhido na PUC-Rio, quando do meu ingresso no Mestrado, pelo Prof. Danilo Marcondes, que da mesma forma me orientou no presente trabalho, também com relação a ele não me arrisco a medir sua importância. Na mesma Universidade fui igualmente bem recebido pela Prof. ${ }^{a}$ Vera Bueno que fez, sobretudo, com que eu aprendesse valiosas lições de humildade e respeito.

Marcus Reis (UFF), Gisele Amaral (UFRN), Vicente Dobroruka (História, UnB), Izabela Bocayuva (UERJ) e Plínio Smith (UNIFESP), embora em diferentes épocas e de diferentes modos, foram interlocutores constantes sobre o conteúdo da pesquisa e a metodologia da mesma.

Myles Burnyeat (Robinson College- Cambridge), David Sedley (Christ's College- Cambridge), Barry Stroud (Berkeley- University of California) e Gisela Striker (Department of Classics- Harvard University) gentilmente cederam os direitos para tradução e publicação de artigos seminais para 
essa pesquisa, além disso, sempre foram solícitos em esclarecimentos de dúvidas.

Boa parte desse trabalho não seria possível sem o auxílio dos professores do curso de Graduação em Letras Português/Grego da UERJ, especialmente da Prof. ${ }^{a}$ Luciene Oliveira.

No período de março de 2012 a março de 2013 submeti os resultados das pesquisas à avaliação dos alunos dos cursos de Epistemologia III e História da Filosofia Antiga IV, na UFF, e dos grupos de estudos da UERJ, suas observações atentas foram incorporadas ao presente texto.

Ainda no âmbito acadêmico, pude desfrutar da companhia e dos conselhos dos amigos Alexsandro Magalhães e Pedro Carné.

Minha família e a da minha esposa ofereceram todo tipo de suporte para essa pesquisa, especialmente o apoio emocional, a quem devo agradecer ainda à Tatiana e nossos filhos.

A todos os citados sou sinceramente muito grato, e também a outros que talvez não tenham sido mencionados. 


\section{Resumo}

Brito, Rodrigo Pinto de; Marcondes, Danilo. Da coerência pragmática da dýnamis cética em uma perspectiva dialética. Rio de Janeiro, 2013. 213p. Tese de Doutorado - Departamento de Filosofia, Pontifícia Universidade Católica do Rio de Janeiro.

Tese em que se desenvolve um modo de interpretar o ceticismo Antigo, especialmente o pirrônico, e que isenta a dýnamis cética da acusação de apraxía. Essa 'via média' interpretativa emerge como um modo de superar as aporias entre as interpretações rústica e urbana e tem sua eficácia testada quando aplicada como ferramenta exegética para 'Contra os Retóricos'.

\section{Palavras-chave}

Apraxía; protoceticismo; 'Vida de Pirro'; sucessores de Pirro; média academia; estoicismo; pirronismo; Sexto Empírico; via média; 'Contra os retóricos'. 


\section{Abstract}

Brito, Rodrigo Pinto de; Marcondes, Danilo (Advisor). On the pragmatical coherence of the skeptical dýnamis under a dialectical perspective. Rio de Janeiro, 2013. 213p. PhD Thesis - Departamento de Filosofia, Pontifícia Universidade Católica do Rio de Janeiro.

Thesis in which we develop a way to interpret the Ancient skepticism, especially the pyrrhonic one, and we exempt the skeptical dynamis of the apraxia's accusation. This interpretive 'middle way' emerges as a mode to overcome the aporias between the rustic and urbane interpretations, and it has its efficiency tested when applied as an exegetical tool for 'Against the Rethors'.

\section{Keywords}

Apraxia; proto-skepticism; 'Life of Pyrrho'; Pyrrho's succession; middle academy; stoicism ; pyrrhonism; Sextus Empiricus; middle way; 'Against the rethors'. 


\section{Sumário}

1 Abreviações 12

2 Introdução 19

2.1. Questão de fato 19

2.2. Objetivos 20

2.3. Metodologia 21

$\begin{array}{ll}\text { 2.4. Observações preliminares } & 21\end{array}$

3 A acusação da inviabilidade prática do ceticismo no período Moderno 23

3.1. Ceticismo e niilismo 23

3.2. Hume e a apraxia 26

4 Apraxía, autorefutabilidade e fórmulas céticas 30

4.1. No protoceticismo 30

4.2. Na 'Vida de Pirro' em D.L. 36

4.3. Nos sucessores de Pirro 51

5 Apraxía, autorefutabilidade e fórmulas céticas no debate da academia X Stoá 63

5.1. Timão, Arcesilao, Carnéades e Clitômaco 63

5.2. Um interlúdio sobre a filosofia da Stoá 67

5.3. O sistema filosófico tripartite da Stoá 77

5.4. A física estoica $\quad 79$

5.5. A ética estoica 88

5.6. A teoria estoica do conhecimento 94

5.7. Arcesilao X estoicos 99

5.8. Carnéades $X$ estoicos e epicuristas 104

5.9. Clitômaco, Filo de Larissa, Antíoco, Cícero, Enesidemo e Agripa 110

6 Problemas na interpretação de Sexto Empírico 
6.1. O legado do ceticismo até Sexto 113

6.2. A interpretação rústica e a urbana 116

6.3. A "via média" 126

6.4. Uma conclusão provisória 133

7 Análise de 'Contra os retóricos' 135

7.1. Esquema geral do argumento de Adv. Rhet. 135

7.2. Adv. Rhet. passo a passo 136

7.2.1. A busca pela definição de retórica 136

7.2.2. As refutações às definições disponíveis 138

7.2.2.1. As refutações à definição de retórica como Téxv 139

7.2.2.2. As refutações às definições da retórica como ciência do discurso e produtora da persuasão 142

7.3. Adv. Rhet. 73-113 146

8 Conclusão 149

9 Referências bibliográficas $\quad 150$

9.1. Fontes primárias: textos e traduções 150

9.2. Fontes secundárias: artigos e livros

9.3. Obras de referência: dicionários, léxicos e gramáticas 167

10 Glossário de termos e expresses gregas 169

11 Anexo: quadros conceituais e tábua cronológica 190

11.1. Quadro conceitual da filosofia estoica 190

11.2. Quadros conceituais do ceticismo antes de Sexto Empírico 191

11.3. Tábua cronológica dos principais pensadores Antigos citados e suas filiações filosóficas 205 
Homem! Por mais que a Idéia desintegres, Nessas perquisições que não têm pausa, Jamais, magro homem, saberás a causa De todos os fenômenos alegres!

Augusto dos Anjos - As cismas do destino 


\section{Abreviações}

* Aécio

Plac. $=$ Opiniões dos Filósofos

* Alexandre de Afrodisias

in Top. = Comentário aos Tópicos de Aristóteles

* Apiano

App. $=$ Guerras Civis

Hisp. $=$ Guerras Hispânicas

* Aristófanes

$\boldsymbol{A r} \cdot \boldsymbol{N u} \cdot \mathbf{=}$ Nuvens

* Aristóteles

Met. $=$ Metafísica

Poet. $=$ Arte Poética

Phys. $=$ Física

Rhet.$=$ Arte Retórica

Nic. Eth. = Ética a Nicômaco

* Ateneu

Deip. $=$ Deipnosofistas

* Aulo Gélio 
Noct. Att. $=$ Noites Áticas

* Calcídio

in Tim. = Comentário ao Timeu de Platão

* Cícero

Acad. $p r .=$ Acadêmica livro I

Acad. pos. $=$ Acadêmica livro II

De Off . = Sobre os deveres

De Or. = Sobre a Oratória

De Fat. $=$ Sobre o Destino

De Fin. $=$ Sobre os Fins

Luc. = Lúculo

$\boldsymbol{N D}=$ Sobre a Natureza dos Deuses

Tusc.$=$ Disputações Tusculanas

* Cleomedes

Cael. $=$ Os Céus

* Clemente de Alexandria

Strom. = Miscelâneas

* Demóstenes

Dem.$=$ Sobre a Embaixada Falsa

Dem. Or. $=$ Discursos

* Diógenes Laércio 
D.L. = Vidas e Doutrinas dos Filósofos

* Diógenes de Oinoanda

Dio. Oen. Phy. = Fragmentos Físicos de Diógenes de Oinoanda

* Epicteto

Diss. $=$ Discursos

Ench. $=$ Manual

* Ésquines

Aeschin. $=$ Contra Timarco

* Estobeu

$\boldsymbol{E} \boldsymbol{c l}$. $=$ Écloga

Flori. $=$ Florilégios

* Eusébio

$\boldsymbol{P E} .=$ Preparação Para o Evangelho

* Eurípides

Orest. $=$ Orestes

* Filodemo

De Stoi. $=$ Sobre os Estoicos

De Piet. $=$ Sobre a Piedade

* Fócio 
Bib. $=$ Livros

* Galeno

$\boldsymbol{P H P}=$ Sobre as Doutrinas de Hipócrates e Platão

Gal. $=$ Das Faculdades Naturais

Hip. Pror. Com. = Comentário aos 'Prognósticos' de Hipócrates.

* Hermann Diels - Walther Kranz

$\boldsymbol{D K}=$ Fragmentos dos Pré-socráticos

* Heródoto

Hist. $=$ História

* Hipócrates

Hp. Off. $=$ O ofício da medicina

* Isócrates

Isoc. = Evágoras

* Lísias

Lys. $=$ Contra Eratóstenes

* Luciano

Luc. Par. = A Passagem de Peregrino

Luc. Herm. $=$ Hermotimo

Vit. Auct. = Mercado de Filósofos 
* Metrodoro

Metrod. Herc. = Papiro em Herculano 1005, col. IX

* Platão

Apol. $=$ Apologia

Crat. $=$ Crátilo

Fed. Fédon

Fedr. $=$ Fedro

Górg. = Górgias

Parm. $=$ Parmênides

Phlb. $=$ Filebo

Rep. $=$ República

Sof. $=$ Sofista

Teet. $=$ Teeteto

Tim. $=$ Timeu

* Plutarco

Adv. Col. $=$ Contra Colotes

Vit. Par. $=$ Vidas Paralelas

Com. Not.$=$ Contra os Estoicos quanto às Concepções Comuns

St. Rep. $=$ Sobre as Autocontradições Estoicas

* Políbio

$\boldsymbol{P l b}=$ História

* Ryle

PRyl. = Papiro de Ryle 
* Sêneca

Ep. $=$ Cartas

Ir $\boldsymbol{a}=$ Sobre a Cólera

Quaest. Natu. = Questões Naturais

* Sexto Empírico

$\boldsymbol{P . H .}=$ Esboços Pirrônicos

Adv. Log. = Contra os Lógicos

Adv. Phy. $=$ Contra os Físicos

Adv. Eth. = Contra os Éticos

Adv. Gram. = Contra os Gramáticos

Adv. Rhet. $=$ Contra os Retóricos

Adv. Mus. $=$ Contra os Músicos

* Simplício

in Cael. $=$ Comentário à Sobre o Céu de Aristóteles

in Phys. = Comentário à Física de Aristóteles

* Siriano

in Metaph. = Comentário à Metafísica de Aristóteles

* Sófocles

Trach.$=$ As Traquínias

* Temístio

Priv.Or. $=$ Orações Privadas 
* Tucídides

Tuc. $=$ História da Guerra do Peloponeso

* Von Arnin

SVF I, II, III = Fragmentos do Estoicismo Antigo, volumes I, II e III

Ind. St. Herc. = Índice Estoico de Herculano

* Xenofonte

Mem. $=$ Memoráveis 


\section{Introdução}

Introdutoriamente, faremos aqui algumas considerações preliminares sobre (1) nossa questão de fato; (2) objetivos; (3) metodologia, além de certas observações adicionais.

\subsection{Questão de fato}

Em poucas palavras, a questão sobre a qual nos debruçaremos ao longo de todo este trabalho é a da 'inviabilidade prática do ceticismo', ou apraxia ( $\alpha \pi \rho \alpha \xi i ́ \alpha)$.

Começaremos com o levantamento de como o problema surgiu no contexto Moderno, mais próximo de nós e cujas fontes são muito mais bem preservadas do que as Antigas. Considerando essa proximidade cronológica e a disponibilidade das fontes, pensamos que as acusações contemporâneas de que a postura cética conduz a uma vida que não pode ser vivida na prática, porque para viver é preciso crer, são originadas no período Moderno.

Contudo, apesar disso, os filósofos Modernos não foram os pioneiros na crítica que, de fato, começou quando do surgimento do próprio ceticismo, seja pirrônico ou acadêmico, e quiçá antes mesmo disso, como procuraremos demonstrar.

Dessa forma, passaremos à investigação de como surgiu a crítica, primeiramente proferida por Aristóteles $\left(\right.$ Met. $\left.\Gamma=\alpha \dot{\alpha} \delta v \alpha \mu \mu^{\alpha} \alpha\right)$ contra alguns pensadores que foram tratados mais tardiamente, por Diógenes Laércio e Sexto Empírico, como antecessores do ceticismo. Ora, se os céticos se consideraram de alguma forma herdeiros desses 'protocéticos', também tiveram, por seu turno, que arcar com o ônus da herança da crítica aristotélica.

Em seguida, nos voltaremos para uma investigação das ocorrências da crítica quanto à própria 'Vida de Pirro' (D.L. IX, 61-71), em que ele é por vezes descrito como incorrendo em um comportamento extravagante, inédito, excêntrico 
ou imprevisto ( $\dot{\alpha} \pi \rho \circ o ́ \rho \alpha \tau o \varsigma)$, e também para a recorrência do argumento contra os sucessores de Pirro.

Uma vez que tivermos nos detido na sucessão de Pirro a Timão de Fliunte, poderemos nos voltar para o ceticismo de modalidade acadêmica, em cujos aguerridos debates contra os estoicos poderemos ver surgir uma acusação de $\grave{\alpha} \pi \rho \alpha \xi i ́ \alpha$ mais contundente. Além disso, se compreendermos as vicissitudes do debate da academia $X$ a Stoá, poderemos também entender a motivação de Enesidemo de Cnossos para romper com a academia e reviver, ou talvez inventar, o pirronismo, erigindo Pirro à posição de herói fundador desse tipo de ceticismo.

Mas, mais uma vez, se Enesidemo estava disposto a edificar tal postura cética, em nome de Pirro, teve também de submeter-se às consequências da crítica

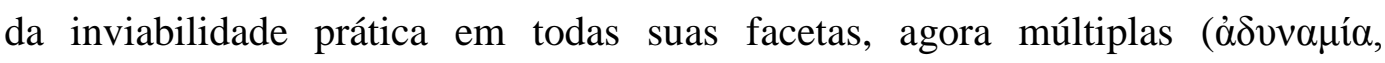

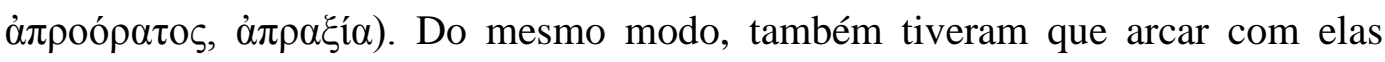

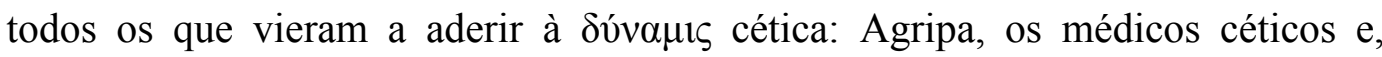

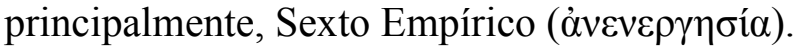

\subsection{Objetivos}

Nossos objetivos são, em suma, demonstrar como os argumentos anticéticos surgem nas diferentes etapas do ceticismo, até Sexto Empírico.

Ademais, ao fazê-lo, nos ateremos também aos modos como os céticos reverteram esses argumentos, dando à sua $\delta$ v́vaıৎ a devida coerência pragmática, culminando nas obras de Sexto que, por serem mais maduras, chegam a se adiantar a outras críticas vindouras, talvez mesmo àquelas Modernas.

Para interpretarmos a coerência pragmática do ceticismo sextiano, teremos que verificar se as exegeses correntes, usualmente chamadas de rústica e urbana, são suficientes. Pensamos que não, além disso, são mutuamente exclusivas,

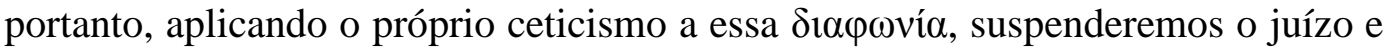
não aderiremos a nenhuma integralmente, ao invés, coagidos pelo modo como percebemos o ceticismo, engendraremos outra ferramenta interpretativa, uma 'via média' que terá sua eficácia atestada mediante análise de 'Contra os retóricos' (Adv. Rhet.). 


\subsection{Metodologia}

Nosso método é a dialética, não a de Hegel, mas a antiga, que visa examinar as posições verificando sua coerência. Pensamos que assim seremos capazes de entender as minúcias dos debates que ocorreram entre os agonistas quanto à viabilidade de suas filosofias. E também, esse método satisfaz nossa exigência de clareza, uma vez que poucas das obras que os pensadores Helenísticos escreveram sobre suas próprias doutrinas sobreviveram, temos que reconstruir suas posições amiúde a partir dos escritos de seus críticos, recolhendo e organizando os fragmentos.

Começaremos pelo diálogo travado pelos próprios Modernos entre si acerca do problema da viabilidade do ceticismo e passaremos à recepção do ceticismo por Hume. Voltaremos aos protocéticos e à dialética entre eles e Aristóteles, depois entre eles e Pirro e entre Pirro e seus contemporâneos; entre os sucessores de Pirro e os acadêmicos e entre eles e os estoicos, bem como entre os próprios filósofos da Stoá. Seguiremos à dialética entre os filósofos da academia e entre eles e Enesidemo, passando por Agripa e pela infiltração nas seitas médicas, até Sexto Empírico.

Seguindo com nossa metodologia, acompanharemos a dialética entre os rústicos e os urbanos, a partir da qual extrairemos a 'via média' e, dialética e analiticamente, a utilizaremos como instrumento para interpretarmos uma obra de Sexto Empírico.

\subsection{Observações preliminares}

Não podemos prosseguir sem determinadas elucidações adicionais.

Primeiramente, nas notas de rodapé explicitaremos as fontes primárias, recomendaremos comparações entre diversos textos e faremos considerações que tentarão desenvolver aspectos filosóficos, históricos e literários que orbitam ao redor do texto principal.

Em segundo lugar, para as fontes primárias utilizamos um sistema de abreviações que são decodificadas com auxílio da tabela que está antes desta 
introdução. Também há, após a bibliografia, um glossário de termos e expressões gregas, bem como um anexo com uma tabela conceitual da filosofia estoica, tabelas conceituais do ceticismo antes de Sexto Empírico e uma tábua cronológica que indica época e linhagem filosófica dos principais pensadores Antigos que citamos.

Finalmente, mas não menos importante, queremos deixar claro que de modo algum pretendemos oferecer aqui uma interpretação derradeira e inequívoca do ceticismo, algo contraditório.

$\underline{\text { Salientamos que a totalidade deste trabalho é meramente um relato das }}$ aparências, uma interpretação do que nos (a)parece ser o ceticismo. 


\section{$3 \mathrm{~A}$ acusação da inviabilidade prática do ceticismo no período Moderno}

\subsection{Ceticismo e niilismo}

La Flèche, o célebre colégio jesuíta de Anjou que outrora fora frequentado por Descartes e Marín Mersenne, abrigou também, por volta de 1734, David Hume que lá começou a elaborar o 'Tratado da natureza humana', cujos livros 'Do intelecto' e 'Das paixões' publicou em 1739, somente um ano depois 'Da Moral' seria publicado. Sua obra não logrou sucesso, pelo contrário, “já saiu natimorta da gráfica, sem sequer alcançar o mérito de provocar um murmúrio entre os zelotes", entretanto, os poucos que a leram chamaram Hume de herege e cético, e mesmo ateu, como se não bastasse, a sombra do ostracismo se avizinhava, e em 1745 foi-lhe vetada a Cátedra de Filosofia Moral da Universidade de Edimburgo.

Muito elucidativa do impacto inicial do 'Tratado' de Hume é a sua 'Carta de um cavalheiro a seu amigo em Edimburgo,2 - em que ele próprio, em uma das raras ocasiões em que se prestou às tréplicas, rebateu as acusações de ceticismo universal (porque "duvida de todas as coisas [...] e sustenta a loucura de fingir acreditar em qualquer coisa com certeza"), de ateísmo ("ao negar a doutrina das causas e dos efeitos"), e de ter "solapado os fundamentos da moral, ao negar a diferença natural e essencial entre certo e errado, bem e mal, justiça e injustiça, tornando a diferença somente artificial e originada em convenções e pactos humanos"3.

Mas não é tudo. Por si só eloquente é o fato de que mesmo o editor que tão arduamente trabalhou para publicar as obras completas de Hume, o Green a quem se atribui uma das edições padrão, considerava que o filósofo deliberadamente havia levado as já inconcebíveis noções de Locke e Berkeley acerca do

\footnotetext{
${ }^{1}$ Ver: 'HUME, D. My own life', in: http://www.consciencia.org/my-own-life-by-david-hume-1776

${ }^{2}$ Ver: 'HUME, D. Carta de um cavalheiro a seu amigo em Edimburgo. Tradução de Smith, P. In: Sképsis, ${ }^{\circ} 1,2007$ '.

${ }^{3}$ Todas as citações nesse parágrafo são da carta citada na nota anterior.
} 
funcionamento da mente humana e sua capacidade de conhecimento a consequências paradoxais e estapafúrdias, afirmando que não podemos conhecer os processos que interligam os corpos ou os fatos, as cadeias causais. Em suma, segundo a interpretação de Hume por Green, não há nada no mundo que faça sentido, exceto as impressões momentâneas e as ideias que esvoaçam pelas nossas consciências ${ }^{4}$.

De fato, no fechamento do primeiro livro do seu 'Tratado', Hume vislumbrou um conflito insuperável entre as exigências da razão e da fé que o fez perguntar-se:

Onde estou, o que sou? De que causas derivo minha existência, e a que condição retornarei? De quem o favor deverei cortejar, a ira de quem devo temer? Que seres me cercam? Sobre quem exerço influência, e quem exerce influência sobre mim? Todas essas questões me confundem, e começo a me imaginar na condição mais deplorável, envolvido pela mais profunda escuridão, e inteiramente privado do uso de meus membros e faculdades. ${ }^{5}$

Porque sua razão o levara à conclusão cética de que ele não conhecia nada além de suas impressões.

Esse conflito entre a filosofia e a própria vida repercutirá nas últimas décadas do século XVIII, e Kant, assim como outros filósofos de seu tempo, se debateu com o problema da autoridade de uma razão que fora capaz de colocar em xeque as bases mesmas da existência.

De um modo geral, pensadores "das Luzes" conferiam uma autoridade singular e notável à razão, o padrão Iluminista soberano da verdade que, imparcial, tinha princípios autoevidentes pelos quais se poderia justificar a moral, o estado e a religião, e que, da mesma forma, poderia criticar todas as crenças e conhecer a natureza. Contudo, todos esses poderes da razão vieram a ser questionados a partir de meados do séc. XVIII, tal guinada ocorreu porque, uma vez incidindo sobre a moral, a religião e o estado, a filosofia e a ciência acabaram por demoli-las, fazendo restar o ateísmo, o fatalismo e o anarquismo, como consequências do avanço do modelo mecanicista de ciência e dos modelos de conhecimento de Hume e de Spinoza, entre outros fatores.

\footnotetext{
${ }^{4}$ Green apud, 'STROUD, B. O Ceticismo de Hume: instintos naturais e reflexão filosófica. Tradução de Smith, P. In: Sképsis, n 3- 4, 2008'.

5 'HUME, D. Tratado da natureza humana. Tradução de Danowski, D. São Paulo: UNESP, 2000'; Livro I, Parte IV, Seção vii $\S 8$ (doravante: Tratado, 1.4.7.8).
} 
Spinoza, em seu 'Tratado teológico-politico', publicado anonimamente em 1670, criticou a religião revelada e o tipo de conhecimento envolvido nas profecias - que na verdade é fantasia e se relaciona com a imaginação —, para isso aplicou o método cartesiano ao estudo e interpretação das escrituras. Como resultado, ele "transferiu o lugar da verdade da religião para o conhecimento

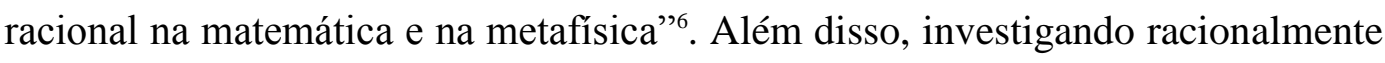
a ocorrência de milagres, foi muito mais além do que faria Hume posteriormente e afirmou categoricamente sua impossibilidade, tendo em vista que, segundo ele, na natureza, os fenômenos sucediam-se de acordo com uma ordem fixa e imutável, o que haveria de fato seria a ignorância de seu funcionamento e das cadeias causais envolvidas nos fenômenos naturais. A aplicação de um método racional à investigação das escrituras fez com que o 'Tratado' de Spinoza fosse considerado "um livro pernicioso e detestável"7.

Se há uma ligação determinada e necessária intrínseca à natureza, por outro lado, a razão, capaz de conhecer, também opera por ligações determinadas e necessárias intrínsecas às ideias, daí a famosa proposição 7 da 'Ethica, ordine geométrico demonstrata ${ }^{98}$ (publicada postumamente em 1677): “Ordo et connexio idearum idem est ac ordo et connexio rerum". Desse modo, para cada evento B deve haver um evento anterior A, tal que, dado A, B ocorre necessariamente. Mas, esse princípio, uma vez universalizado, leva ao ateísmo e ao fatalismo, pois deus e a liberdade têm que ser causas autoengendradas, que agem sem que haja uma causa mais anterior a elas.

Mesmo o modelo de conhecimento de Kant explicava a razão em termos de atividade a priori e declarava que ela somente conhece a priori o que ela própria cria, ou o que se conforma com as leis de sua própria atividade. Não obstante, ao generalizarmos esse princípio, tudo o que poderíamos conhecer seriam os produtos de nossa própria atividade mental, e não uma realidade independente dessa atividade, levando-nos ao solipsismo. Essa consequência da teoria kantiana do conhecimento foi apontada por Hamann, Jacobi, Wizenmann, Schulze, Platner

\footnotetext{
6 'POPKIN, Richard. História do Ceticismo: de Erasmo a Spinoza. Rio de Janeiro: Francisco Alves, 2000'.

${ }^{7}$ Bayle citado na obra de Popkin mencionada na nota acima.

8 'SPINOZA, B. Ética. São Paulo: Editora Autêntica, 2009'.
} 
e Maimon ${ }^{9}$, os primeiros críticos de Kant que defendiam, por seu turno, Spinoza ou Hume.

Jacobi chegou a afirmar que a razão e o ceticismo levavam a uma espécie de niilismo (usado, neste contexto, para denotar as consequências do solipsismo gerado por todas as investigações racionais) onde se duvidaria da existência do mundo externo, de outras mentes e de deus. Isso, por sua vez, tornava impossíveis os estabelecimentos de regras morais para a ação correta, do estado e da justiça, colocava em xeque toda a realidade e, em suma, tornava a vida impossível de ser vivida.

Agora, voltando a Hume, a fragilidade da vida diante dos questionamentos céticos já o afligia no fim da década de 1730 .

\subsection{Hume e a apraxia}

Muito se discute sobre as fontes literárias dos ceticismos Antigos, de modalidade pirrônica ou acadêmica, disponíveis não só à época de David Hume, mas também a partir da Renascença. Desse modo, sabe-se que a difusão do pirronismo na Europa, através dos textos de Sexto Empírico, começa a ocorrer a partir do séc. XV. Havendo, assim, uma edição latina dos 'Esboços Pirrônicos' ('Pirroniarum Informacionum libri'), datando de 1470, bastante próxima do texto original em grego, que foi utilizada por Hermann Mutschmann na sua edição crítica da obra de Sexto $^{10}$. Há uma versão latina, também de 1470, do mesmo livro ('Pirronie Informaciones'), bem como de fragmentos de 'Adversus Mathematicos' III-V. Outra tradução latina do séc. XV é a de Giovanni Lorenzi, que faleceu em 1501.

Do séc. XVI há a versão latina de John Wolley, que viveu entre 1530-96, bem como uma tradução de cerca de 1550, ainda não estudada, dos 'Esboços Pirrônicos', de Paéz de Castro, um grande humanista espanhol que lia hebraico, grego, caldeu e árabe e que fazia parte do círculo de Florian de Ocampo, Juan de Vergara, Alvar Gómez, Ambrosio de Morales, Diego Hurtado de Mendoza, e do cardeal de Burgos, de quem se tornou bibliotecário. Provavelmente, o manuscrito grego que Paéz utilizou para a tradução é um que pertenceu até o séc. XVII ao

\footnotetext{
${ }^{9}$ Ver: 'BEISER, F. C. The Fate of Reason: German Philosophy from Kant to Ficht. Londres: Harvard University Press, 1987'.
} 
Convento de S. Vicente de Plasencia e hoje é identificado como "Ms. Madrid Bib. Nac. 4709 (O 30)".

Apesar disso, com a exceção de Gianfrancesco Pico della Mirandola, que lia grego e pôde ler Sexto no original, a tradução mais largamente difundida foi a versão latina de Estienne de 1562, que é a fonte mais provável de Sanchez, Montaigne, Charron e, mais tarde, Gassendi e mesmo Descartes, embora não se saiba ao certo quais autores céticos ele tenha realmente lido.

Do séc. XVII há a edição das obras de Sexto de 1621 dos irmãos Chouet, também a edição inglesa completa dos 'Esboços Pirrônicos' na popularíssima 'História da Filosofia', de Thomas Stanley (publicada de 1655 a 1660 e reimpressa em 1687). No séc. XVIII tem-se a edição de J. A. Fabricius do texto grego, com tradução latina, das obras completas de Sexto Empírico. Além disso, houve a tradução francesa das obras completas de Sexto, de 1725, e uma tradução em três livros dos 'Esboços Pirrônicos', por Claude Huart ('Les Hipotiposes ou Institutions Pirroniennes de Sextus Empiricus en trois livres, Traduites du grec') que tem duas revisões detalhadas, uma de 1726 (Leipzig), e outra de 1727 (nas 'Memoires de Trevoux') em que o pirronismo é atacado por vinte e seis páginas, uma vez que ameaçaria a verdadeira religião.

Ademais, embora não sejam traduções de Sexto, há o 'Examen $d u$ Pyrrhonisme' de Jean Pierre de Crousaz, que pretende responder a Sexto, Huet e Bayle, o que atesta quão amplamente circulavam dos dois últimos respectivamente as seguintes obras: 'Traite de la foiblesse del 'esprit humain' e 'Dictionnaire' ${ }^{11}$.

Contudo, apesar da ampla difusão dos ceticismos Antigos no séc. XVIII, Hume não demonstra, quer no 'Tratado' ou na 'Investigação', um conhecimento adequado do ceticismo pirrônico (e nem mesmo do acadêmico, de fato, mal sabe distinguí-los), conforme apresentado pela obra de Sexto. Antes, apesar de citar Sexto em grego (na segunda 'Investigação', seção IV), o que denota que talvez tivesse acesso a uma versão que não a latina de Estienne, e das estranhas citações que faz na seção II da segunda 'Investigação' e na 'História Natural da Religião',

\footnotetext{
${ }^{10}$ Ver: 'Sexti empirici Opera, recensuit Hermannus Mutschmann... addenda et corrigenda adiecit I.Mau, Leipzig, 1958'.

${ }^{11}$ Ver: 'FLORIDI, L. The Diffusion of Sextus Empiricus's Works in the Renaissance. In: Journal of the History of Ideas, Vol. 56, $\mathrm{n}^{\circ} 1$. University of Pennsylvania Press'; e 'POPKIN, R. Sources of Knowledge of Sextus Empiricus in Hume's Time. In: Journal of the History of Ideas, Vol. 54, $\mathrm{n}^{\circ}$ 1, 1993. University of Pennsylvania Press'.
} 
sua fonte para o pirronismo parece ser mais de segunda mão (através de Huet ou Bayle $)^{12}$, ou advinda de uma leitura de Diógenes Laércio, que compila doxografias depreciativas e encomiásticas sobre a 'Vida de Pirro' em um único livro, tornando dúbia, para dizer o mínimo, a interpretação sobre a coerência da filosofia/vida de Pirro, herói modelo do ceticismo pirrônico ${ }^{13}$.

Mesmo que por hora não queiramos nos alongar deveras em Hume, não podemos seguir sem citar o trecho que nos parece ser o mais emblemático da acusação de que o ceticismo conduz a uma vida que não pode ser vivida ${ }^{14}$ :

Basta apenas perguntar a um desses céticos o que tem ele em mente e qual é o seu propósito com todas essas excêntricas indagações. Ele será imediatamente tomado de perplexidade e não saberá o que responder. Um seguidor de Copérnico, ou um de Ptolomeu, defendendo cada qual seu diferente sistema de astronomia, pode esperar produzir em sua audiência uma convicção que permanecerá constante e duradoura. Um Estoico ou um Epicurista expõem princípios que não apenas podem ser duradouros, mas também têm uma influência duradoura na conduta e nas maneiras. Mas um pirrônico não pode esperar que sua filosofia venha a ter alguma influência constante na mente humana; ou, se tiver, que essa influência seja benéfica para a sociedade. Ao contrário, ele deverá reconhecer — se puder reconhecer alguma coisa - que toda a vida humana seria aniquilada se seus princípios fossem adotados de forma constante e universal. Todo discurso e toda ação cessariam de imediato, e as pessoas mergulhariam em completa letargia, até que as necessidades naturais insatisfeitas pusessem fim à sua miserável existência. É verdade que há poucos motivos para temer tamanha fatalidade, pois a natureza é sempre demasiado forte diante dos princípios. E embora um pirrônico, com seus raciocínios profundos, possa lançar a si próprio e a outros em uma perplexidade e confusão momentâneas, a primeira e mais banal ocorrência da vida porá em fuga todas as suas dúvidas e hesitações e deixa-lo-á em posição exatamente semelhante, em

\footnotetext{
${ }^{12}$ Ver: 'ANNAS, J. Hume e o Ceticismo Antigo. In: Sképsis, n 2, 2007'.

${ }^{13}$ Ver: 'GAZZINELLI, G. G. A Vida Cética de Pirro. São Paulo: Edições Loyola, 2009'.

${ }^{14} \mathrm{Um}$ dos motivos para a nossa predileção por esse trecho é que ele faz parte da 'Investigação', e não do 'Tratado'. Como o próprio Hume diz na 'Nota introdutória à Investigação' que, não considerando o "Tratado" "um trabalho bem-sucedido", ele "reconheceu seu erro em ter ido muito cedo ao prelo e rearranjou todo o material nas seções [da 'Investigação'] que se seguem, nas quais espera ter corrigido algumas negligências em seus raciocínios anteriores e, mais ainda, em sua expressão", porque "vários autores que honraram a filosofia do autor com suas réplicas cuidaram de dirigir todas as suas baterias contra aquela obra de juventude que o autor nunca autorizou, e presumiram ter triunfado em cada uma das vantagens que supostamente alcançaram contra ela", assim sendo, Hume "deseja, doravante, que os textos a seguir - e somente eles - possam ser considerados como contendo suas opiniões e princípios filosóficos" ("HUME, D. Uma investigação sobre o entendimento humano. Traduzido por Marques, J. O. A. São Paulo: UNESP, 2003'; Nota introdutória, o grifo é nosso). Assim sendo, pensamos que se citássemos um trecho do 'Tratado', poderiamos ser confutados por algum defensor incauto do ceticismo (de Hume), que asseriria que o próprio Hume abandonou sua interpretação mais anterior do ceticismo ao escrever a 'Investigação' e advertiu que somente ela representa sua filosofia. Contudo, citando justamente a 'Investigação', mostramos que a posição de Hume quanto ao ceticismo manteve-se nos dois escritos, diríamos ainda que, na verdade, ela eriçou-se ainda mais, tendo em vista que após a repercussão negativa do 'Tratado', que trouxe à Hume a acusação de ceticismo, ele precisou reforçar que não era um cético e que, de fato, rejeitava o ceticismo por reconhecer suas consequências, para ele negativíssimas.
} 
tudo o que diz respeito à ação e especulação, à dos filósofos de qualquer outra seita, ou daqueles que nunca se envolveram em investigações filosóficas. Quando desperta de seu sonho, ele é o primeiro a rir-se de si mesmo e a confessar que suas objeções são puro entretenimento, e só tendem a mostrar a estranha condição da humanidade, que está obrigada a agir, a raciocinar e a acreditar sem ser capaz, mesmo pelas mais diligentes investigações, de convencer-se quanto às bases dessas operações, ou de afastar as objeções que podem ser levantadas contra elas. ${ }^{15}$

Mas Hume não foi o primeiro a fazer essas críticas, na verdade, elas já teriam surgido mesmo séculos antes de Sexto Empírico.

15 'HUME, D. Uma investigação sobre o entendimento humano. Traduzido por Marques, J. O. A. São Paulo: UNESP, 2003'; Seção XII, Parte 2, § 23 (doravante: Investigação, 12.2.23). Compare com a posição de Hume quanto ao ceticismo em Tratado, 1.4.1.1: "Em todas as ciências demonstrativas, as regras são certas e infalíveis; mas quando as aplicamos, nossas faculdades, falíveis e incertas, têm uma grande tendência a delas se afastar e cair em erro. Por isso, em todo raciocínio, devemos conferir e controlar nosso primeiro juízo ou crença mediante um novo juízo; e devemos ampliar nossa visão para abranger uma espécie de história de todos os casos em que seu testemunho foi legítimo e verdadeiro. Nossa razão deve ser considerada uma espécie de causa, cujo efeito natural é a verdade; mas esse efeito pode ser frequentemente impedido pela irrupção de outras causas, e pela inconstância de nossos poderes mentais. Desse modo, todo conhecimento degenera em probabilidade; e essa probabilidade é maior ou menor, segundo nossa experiência da veracidade ou falsidade de nosso entendimento e segundo a simplicidade ou a complexidade da questão". Enfatizamos que nessa passagem tem-se uma ocorrência do ceticismo que, por mais negativa que seja, cumpre a tarefa positiva de inspecionar as crenças, comparando-as umas às outras, fazendo emergir do emaranhado de crenças que se verificaram mais ou menos verdadeiras conforme as circunstâncias, um critério de verdade: a probabilidade. Nesse caso, portanto, o ceticismo é admitido no seio da filosofia do 'Tratado', sendo propedêutico à probabilidade, ainda frágil tendo em vista a "fraqueza da faculdade de julgar" que é acentuada por dúvidas "ao infinito; até que, finalmente, nada reste da probabilidade original". Porém, ao demolir a probabilidade através, mais uma vez, do ceticismo, há de surgir outro critério mais forte e derradeiro, "a natureza [que], por uma necessidade absoluta e incontrolável, determinou-nos a julgar, assim como a respirar e a sentir", de modo que "não podemos deixar de considerar certos objetos de um modo mais forte e pleno em virtude de sua conexão habitual com uma impressão presente, como não podemos nos impedir de pensar enquanto estamos despertos, ou de enxergar os objetos circundantes quando voltamos nossos olhos para eles em plena luz do dia. Quem quer que tenha se dado ao trabalho de refutar as cavilações desse ceticismo total, na verdade debateu sem antagonista e fez uso de argumentos na tentativa de estabelecer uma faculdade que a natureza já havia antes implantado em nossa mente, tornando-a inevitável." (Tratado, 1.4.1.6 e 7). Finalmente, acentuamos que há questões em jogo no ceticismo de Hume (e no ceticismo Moderno) muito diferentes das que estavam em jogo no ceticismo de Sexto Empírico, retornaremos a isso mais tarde. 


\section{Apraxía, autorefutabilidade e fórmulas céticas}

Mesmo que não se concorde que haja uma linha evolutiva e contínua indo do chamado "protoceticismo", passando por Pirro, pelo ceticismo acadêmico, pela cisão de Enesidemo e a criação de seus tropos, pelo surgimento dos tropos de Agripa, pela infiltração do ceticismo nas discussões médicas, culminando com Sexto Empírico, ainda assim há de se concordar que essas fases representam diferentes momentos da história do ceticismo Antigo, e em algumas delas é possível detectar a acusação de apraxía como argumento contra os céticos.

\subsection{No protoceticismo}

De um modo geral, o ceticismo pode ser entendido como um tipo de postura filosófica presente mesmo em filósofos ou filosofias dogmáticas (que fazem asserções positivas ou negativas sobre o conhecimento, a moral, o correto, a física e etc. $)^{16}$. Assim, na Antiguidade, antes mesmo de Pirro e dos ceticismos de modalidade pirrônica ou acadêmica, havia filósofos ou argumentos que eram, em certos aspectos, céticos (e que são, por antecederem ao próprio Pirro, chamados usualmente de protocéticos), dessa forma:

Há quem diga que Homero iniciou essa escola, porque sobre as mesmas coisas ora declarou uma coisa, ora outra e nada definitivamente dogmatizou sobre as afirmações. Na sequência, também as sentenças dos sete sábios são céticas, como "nada em excesso" e "a certeza [está] junta da cegueira". (D.L IX, 71).

Da mesma forma que Homero e por um mesmo motivo, a saber, a

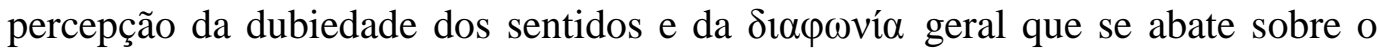
próprio "ânimo dos seres humanos mortais [que] muda a cada dia que Zeus faz

16 Dessa forma, vê-se, no período Moderno, por exemplo, um ceticismo propedêutico ao dogmatismo que, por sua vez, é erigido mais posteriormente enquanto se desenvolve o argumento. 
nascer" ${ }^{\text {17 }}$, também Arquíloco e Eurípides são vistos como tendo admitido um certo ceticismo.

No âmbito estritamente filosófico, Xenófanes de Cólofon é considerado cético ao rejeitar os mitos e ao negar a possibilidade do conhecimento, Zenão de Eléia é considerado cético ao negar o movimento, Demócrito, para quem tudo se dava por convenção, ao negar que as coisas possuem em si qualidades, e Heráclito e Empédocles ao rejeitarem, assim como Xenófanes, o conhecimento ${ }^{18}$.

Mas, apesar de terem, em algum momento, proferido asserções que podem ser consideradas céticas (equivocadamente, por tratar-se de dogmatismo negativo), os filósofos citados acima são claramente dogmáticos (positivos mesmo). Pois, Xenófanes foi "o primeiro a postular a unidade"19, quando "explica nos seus mitos que aquilo a que chamamos todas as coisas é na verdade uma só"20 e "afirma que tudo é Deus"21; Zenão de Eléia, como Xenófanes, postulava o uno e dizia que "se houvesse muitas coisas, estariam sujeitas a impossibilidades" 22 e apresentou argumentos "que causam dificuldades aos que tentam solucionar os problemas que eles apresentam",23; Demócrito e seu companheiro Leucipo "sustentam que os elementos são o cheio e o vazio, aos quais dão o nome de 'o que é' e 'o que não é",24 e, por sua vez 'aquilo que é', os átomos, "se movem em virtude do seu peso, deslocam-se através do vazio, sem que esse se lhes oponha ou ofereça resistência [...] pois [os átomos] estão espalhados em toda a volta" 25 ; o obscuro Heráclito, para quem, por exemplo, "a

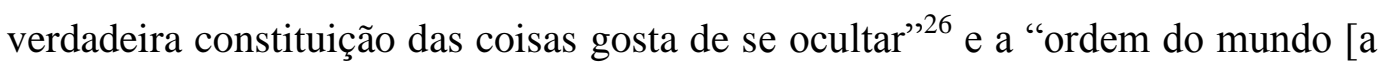
mesma de todos] não a criou nenhum dos deuses, nem dos homens, mas sempre existiu e existe e há de existir: um fogo sempre vivo, que se acende com medida e com medida se extingue" ${ }^{27}$; finalmente, Empédocles "foi o primeiro a dizer que

\footnotetext{
${ }^{17}$ Fr. 115 L-B de Arquíloco em D.L. IX, 71.

${ }^{18}$ D.L. IX, 71-74.

${ }^{19}$ Met. A5, $986 \mathrm{~b} 18$.

${ }^{20}$ Sof. $242 \mathrm{D}=D K 21$ A 29.

${ }^{21}$ Met. A5, 986b 21.

${ }^{22}$ Parm. 127D-128a.

${ }^{23}$ Phys. Z9, 239 b9 = DK 29 A 25.

${ }^{24}$ Met. A4, 985b $4=D K 67$ A 6.

${ }^{25}$ in Phys. 1318, $35=$ DK 68 A 58.

${ }^{26}$ Priv.Or. 5, p.69 D = Fr. 123. Não necessariamente a asserção nesse fragmento expressa um dogmatismo negativo, uma vez que pode também ser interpretada como uma exortação para a investigação.

${ }^{27}$ Strom. V, 104, 1 = Fr. 30.
} 
os 'elementos' eram quatro" 28 , quatro raízes que "cresceram para serem uma só a partir de muitas, de outra vez, separaram-se, de uma que eram, para serem muitas. Dupla é a formação das coisas mortais e dupla a sua destruição; pois uma é gerada e destruída pela junção de todas as coisas, a outra é criada e desaparece, quando uma vez mais as coisas se separam. E essas coisas nunca pararam de mudar continuamente, ora convergindo num todo graças ao Amor, ora separandose de novo por ação do ódio da Discórdia" 29 . Assim, mais uma vez, apesar de poderem erroneamente ser considerados céticos por conta de algumas asserções, esses filósofos claramente são dogmáticos.

Ainda com relação ao protocéticos, Sexto Empírico nos dá pistas de quem seriam em uma célebre passagem de seus 'Esboços Pirrônicos' (P.H. I, 210-220) em que compara sua forma de pirronismo médico com as filosofias de Heráclito e Demócrito, assim como faz Diógenes Laércio, e diferentemente dele, com o cirenaísmo e a "via de Protágoras ${ }^{30}$. Quanto a Heráclito, a semelhança deve-se à percepção da dualidade das coisas, mas "Heráclito faz asserções dogmáticas sobre muitas coisas não evidentes" e, ao invés de, quando diante das oposições,

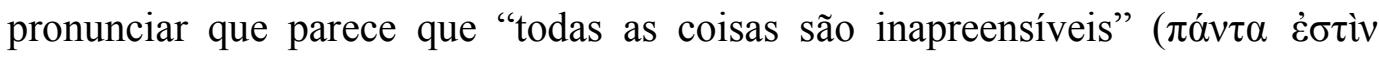

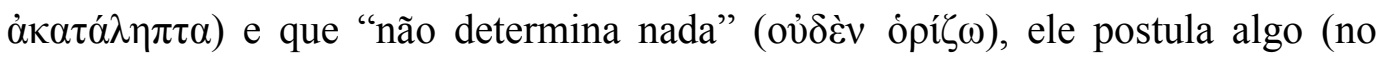
caso, tò $\pi \tilde{v} \rho)$ que subjaz às dualidades e oposições ${ }^{31}$. Quanto à filosofia de Demócrito, as semelhanças se devem, assim como no caso de Heráclito, à percepção da dualidade das sensações (o exemplo é sempre o do mel, que parece doce aos sãos e amargo aos doentes) e ao uso da fórmula "ov่ $\mu \tilde{\alpha} \lambda \lambda \mathrm{ov}$ ", contudo, no caso do ceticismo, essa expressão serve como uma declaração da ignorância e da despretensão à verdade, ao passo que para Demócrito ela indicava que a verdade não estava no macro, mas sim no micro, nos átomos ${ }^{32}$. Por seu turno, a filosofia cirenáica postula aos objetos externos uma real natureza que é

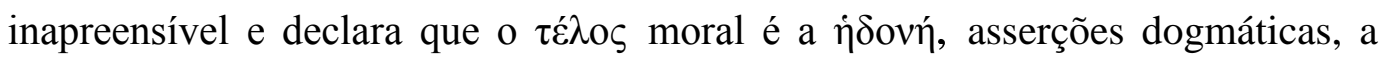
primeira negativa e a segunda positiva. A semelhança é de ordem sensualista, posto que para os cirenáicos, assim como para Sexto, somente se é capaz de

\footnotetext{
${ }^{28}$ Met. A4, 985a 31-3=DK 31 A 37.

${ }^{29}$ in Phys. 158, 1 = Fr. 17, 1-13.

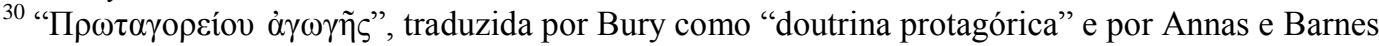
como "persuasão protagórica".

${ }^{31}$ P.H. I, 210.

${ }^{32}$ P.H. I, 213-215. Na seção seguinte efetuamos uma comparação mais precisa entre o pirronismo e o atomismo abderita, bem como elucidamos melhor a expressão ov̉ $\mu \tilde{\alpha} \lambda \lambda$ ov.
} 


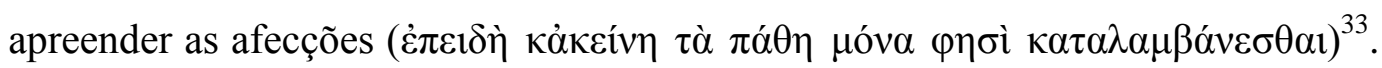
Protágoras, ao postular o "homem como medida de todas as coisas", estabeleceu cada homem como seu próprio critério, "e assim introduz a relatividade" com o

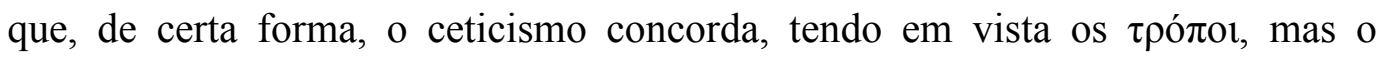
relativismo de Protágoras é uma consequência do seu critério personalista, mas que é, ainda sim, um critério não evidente e, portanto, dogmático ${ }^{34}$, ao passo que

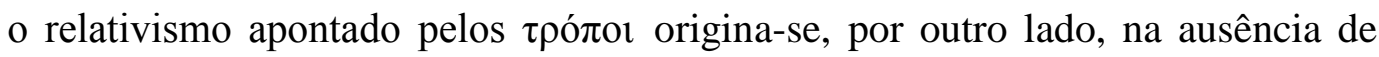

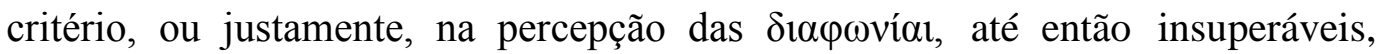
acerca da própria existência de um critério único para as percepções e para o conhecimento $^{35}$.

Agora, muito antes de Sexto Empírico e de Diógenes Laércio, Aristóteles também ponderou, na 'Metafísica' $\Gamma$, os argumentos dos filósofos protocéticos, não por serem argumentos céticos, tendo em vista que não havia em sua época um ceticismo filosófico minimamente formalizado, mas por serem asserções que colocam em xeque o princípio de não contradição - e assim incidem sobre o postulado ontológico de que o ser deve ser (e o que não é [ser] não deve ser) de duas diferentes formas: (1) relativismo, cujo paradigma é a filosofia de Protágoras $^{36}$; (2) e a asserção de que tudo é verdadeiro, ou tudo é falso, cujo paradigma é a filosofia de Heráclito.

Assim, para o estagirita, "é necessário que entre as partes da filosofia exista uma que seja primeira" ${ }^{, 37}$, à qual "compete o estudo dos contrários, e porque ao um se opõe o múltiplo e, ainda, porque à mesma ciência compete o estudo da negação e da privação" 38 , "e dado que o um se diz em múltiplos significados, também esses termos, por sua vez, se dirão em múltiplos significados" ${ }^{\text {"39 }}$, de modo que "é tarefa de uma mesma ciência ocupar-se dessas noções e da substância [...], é tarefa dos filósofos saber indagar sobre todas essas coisas" 40 , "porque essas

\footnotetext{
${ }^{33}$ P.H. I 215-216.

34 A relação de Sexto Empírico com Protágoras é dúbia, por um lado ele considera o sofista dogmático ao aderir a um critério: o homem (P.H. I, 219); por outro lado coloca Protágoras entre aqueles que 'aboliram o critério' $(A d v . \log$. I, 60).

${ }^{35}$ P.H. I 216-220.

${ }^{36}$ Ver: 'BURNYEAT, M. F. Protagoras and Self Refutation in Later Greek Philosophy. In: Philosophical Review 85, 1976.'

${ }^{37}$ Met. Г2, 1004a 5.

${ }^{38}$ Met. Г2, 1004a 10.

${ }^{39}$ Met. Г2, 1004a 20.

${ }^{40}$ Met. Г2, 1004b.
} 
coisas são propriedades essenciais do um enquanto um e do ser enquanto ser, e não enquanto números, linhas ou fogo"41.

Tendo assim defendido a necessidade de uma ciência que lide com o "ser enquanto ser", Aristóteles aprofunda-se na delimitação de sua abrangência, dizendo que

É evidente, portanto, que a uma mesma ciência pertence o estudo do ser enquanto ser e das propriedades que a ele se referem, e que a mesma ciência deve não só estudar as substâncias, mas também suas propriedades, os contrários de que se falou, e também o anterior e o posterior, o gênero e a espécie, o todo e a parte e as outras noções desse tipo. (Met. Г2, 1005a 12-15).

E também que

é evidente que a investigação desses "axiomas" [da matemática e o princípio de não contradição] pertence ao âmbito da mesma ciência, isto é, da ciência do filósofo. De fato, eles valem para todos os seres e não são propriedades peculiares de algum gênero particular de ser com exclusão de outros. E todos se servem desses axiomas, porque eles são próprios do ser enquanto ser, e todo gênero de realidade é ser. (Met. Г3, 1005a 22-25, grifos nossos);

por consequência, quem possui o conhecimento dos seres enquanto seres deve poder dizer quais são os princípios mais seguros de todos os seres. Este é o filósofo. E o princípio mais seguro de todos é aquele sobre o qual é impossível errar: esse princípio deve ser o mais conhecido [...] Este é o mais seguro de todos os princípios, [...] é impossível a quem quer que seja acreditar que uma mesma coisa seja e não seja... (Met. Г3, 1005b 10-22, grifos nossos).

Portanto, mesmo que não faça críticas aos filósofos relativistas (cujo padrão é Protágoras) e aos que asserem que tudo é ou não é (cujo padrão é Heráclito) por serem protocéticos, tendo em vista que uma forma mais organizada de filosofia cética ainda estava por vir, Aristóteles ainda assim os critica por rejeitarem o princípio da não contradição, que é objeto de estudo da filosofia primeira e "vale para todos os seres", pois "é próprio do ser enquanto ser", de modo que "é o princípio mais seguro de todos" e "deve ser o mais conhecido", tornando "impossível a quem quer que seja acreditar que uma mesma coisa seja e não seja”. E em sua crítica, que parte do que ele considera ser essa rejeição implícita do princípio da não contradição por Protágoras e Heráclito, Aristóteles, “por via

\footnotetext{
${ }^{41}$ Met. Г2, 1004b 5. Possivelmente criticando Pitágoras, Filolau de Crotona e Heráclito, respectivamente.
} 
de refutação"42, alega que os que violam esse princípio incorrem na “impossibilidade em palavra”, seu $\lambda o ́ \gamma o \varsigma$ se torna $\alpha \delta \delta ́ v \alpha \tau o \zeta$, palavra que significa sem poder, fraco, incapaz de realizar algo, no caso, o discurso, e é oposta à

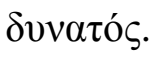

Dessa forma, a refutação de Aristóteles à negação do princípio de não contradição reside no apontamento de que quem rejeita esse princípio rejeita a própria possibilidade do discurso, que só pode ser inteligível graças a esse princípio, porque sem ele sobrevém uma espécie de apraxía discursiva (uma

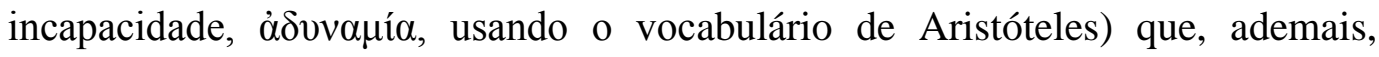
encerra outra armadilha, a autorefutabilidade, tendo em vista que, quem se

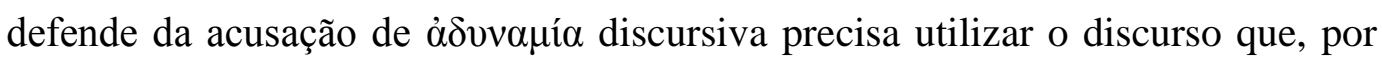
sua vez, só pode ser consistente se estiver de acordo com o princípio de não contradição $^{43}$. É impossível não pensar no 'Tratado do não ser', de Górgias, em conexão com essa discussão:

... se 'o que é' é, ou bem é o ser ou o não ser, ou bem são o ser e o não ser. Ora, não é nem o ser [...], nem o não ser [...], nem o ser e o não ser [...]. Não há, portanto, qualquer coisa para ser. [...] Mas, mesmo se é algo, é, para o homem,

\footnotetext{
${ }^{42}$ Met. Г4, 1006a 12.

43 Para Cassin ('CASSIN, B. O efeito sofístico. São Paulo: Editora 34, 2005'), a refutação de Aristóteles é tripla, e envolve, cito:

“1. Refutação lógica: A refutação mais óbvia, por provir diretamente da própria definição da refutação, consiste em um processo de contradição lógica. O papel do adversário é o de afirmar um enunciado que constitua, direta ou indiretamente, uma recusa do princípio. Podem-se imaginar dois tipos de enunciados. Os primeiros remetem aos próprios termos do enunciado canônico, diretamente — "o mesmo é e não é", "o homem negro é branco". Os segundos constituem um caso particular dos primeiros, aproximando-se dos enunciados já atribuídos por Platão aos relativistas, e se formulam em termos de verdade e de falsidade: tudo é verdadeiro, tudo é falso, o mesmo é simultaneamente verdadeiro e falso. (...)

2. Refutação pragmática: Assim, a segunda descrição não concerne ao nível da contradição lógica, característica de toda refutação, mas se situa no nível do que se poderia adequadamente chamar de uma contradição pragmática. Pois ela não se refere ao conteúdo da tese propriamente dito, mas à posição mesma na qual a refutação põe o adversário: se ele recusa o princípio, aceita, entretanto, cumprir o papel de respondente, isto é, defender sua tese da contradição. A impossibilidade da contradição não lhe é, como ainda há pouco, infligida de fora, pois é constitutiva de sua própria decisão de argumentar: é sua atitude que é autocontraditória. (...)

3. Refutação transcendental: Para que haja refutação, portanto, basta "que o adversário diga algo" (1006 a12-13): isso não implica nem estabelecer uma premissa nem defender uma tese, mas apenas "significar algo, para si e para outrem" (a21). Na equivalência entre essas duas formulações, "dizer algo" e "significar algo", consiste toda a condição da refutação, que é ao mesmo tempo sua condição de base: ela é necessária, não apenas para que haja refutação ou dialética, mas para que haja, antes de tudo, discurso." Ateremo-nos, assim, ao que Cassin chamaria de "refutação pragmática". Agora, ela só pode fazer sentido se o alvo da refutação (os relativistas) levarem a sério as consequências pragmáticas de suas teses. Para aqueles que as tomam apenas como jogos mentais a refutação pragmática é ineficaz, porque não há consequências práticas, nem não contraditórias e nem autocontraditórias.
} 
incognoscível [...]. Por outro lado, mesmo se é apreendido, é incomunicável a outrem. (Adv. Log. I, 66-83).

Assim sendo, se o ceticismo herda da tradição literária, representada por Homero, Arquíloco e Eurípides, as advertências quanto o volubilidade do próprio ser humano; de Xenófanes de Cólofon a crítica aos mitos; de Zenão de Eléia as aporias sobre coisas aparentemente corriqueiras, como o espaço e o tempo; de Górgias as aporias sobre o próprio ser, contra os eleatas; de Heráclito a observação da dualidade das percepções segundo as circunstâncias; de Empédocles e do cirenaísmo uma abordagem sensualista do conhecimento e da existência (em que o homem de fato vive coagido pelas paixões e a elas assente involuntariamente); do atomismo de Leucipo e Demócrito a noção de que muito sobre que se opina se opina arbitrariamente, sem conhecimento; de Sócrates um filosofar que se faz de modo investigativo, existencial e que assume as aporias e a ignorância; e de Protágoras a percepção de que se pode estar sujeito a critérios tão múltiplos quanto são os homens, cada um deles válido para aquele que a ele assente, mas não para outrem; por outro lado, os que vieram a atacar o ceticismo

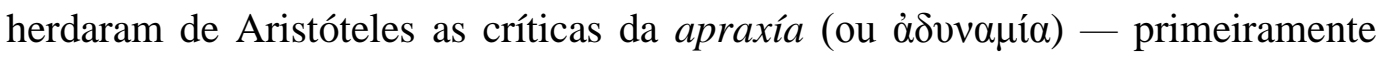
quanto ao discurso, em seguida quanto à própria vida - e da autorefutabilidade, que acompanha a crítica da apraxía, como o anzol é acompanhado pela isca, de modo operacionalmente quase indistinto.

\subsection{Na 'Vida de Pirro’ em D.L.}

Passemos agora à análise dos passos 61-71 da 'Vida de Pirro' em D.L., importante porque pensamos que se o reavivamento do pirronismo foi realmente responsabilidade de Enesidemo, ele tinha que estar disposto a arcar com as consequências da escolha de Pirro como herói fundador, entre as quais a crítica da apraxía. Além disso, em D.L. IX há ocorrências de conceitos próprios da $\dot{\alpha} \gamma \omega \gamma \eta ́$ cética vinculados à vida prática de Pirro.

Antes, porém, ciente das críticas que comumente se faz a D.L. - de que (i) apresenta mais um anedotário sobre as filosofias do que as próprias filosofias (ii) justamente por ser um escritor que não se compromete com as fontes ou com as 
datas, (iii) em suma, com a própria veracidade — desejamos fazer uma defesa, ainda que breve, dessa importante fonte, assim:

$1^{\circ}$ - não havia na época de D.L. (séc. III d.C.) um rigor de citações para sistematização de biografias, de fato, não é estranho que ele não se importasse com isso, estranho e anacrônico é esperar, então, que ele devesse se importar com isso, por que, de um modo geral

As biografias da Antiguidade grega podem parecer estranhas e fantasiosas ao leitor contemporâneo. Um amálgama de história, lenda e ficção, apresentam uma série de dificuldades interpretativas que frustram as tentativas de aproximá-las do gênero Moderno ao qual correspondem. Motivações distintas - literárias, morais, encomiásticas, exortativas, polêmicas ou apologéticas - concedem grande variedade à produção biográfica antiga, dificultando sobremaneira a tarefa de caracterizá-la. $^{44}$

Portanto, apesar de não se dever pretender uma biografia real, pode-se pretender ouvir ecoar nos relatos compilados em cada uma das 'vidas' as motivações das fontes originais, sejam elas "literárias, morais, encomiásticas, exortativas, polêmicas ou apologéticas".

$2^{\circ}$ - Se há realmente inúmeras anedotas entre os relatos das 'vidas', bem como elementos míticos e fantásticos, isso não deve ser visto como demérito, na verdade, justamente "um dos méritos da obra ora traduzida é a evocação da atmosfera do mundo em que viveram os filósofos Antigos" $"$.

$3^{\circ}$ - Se, não obstante, as críticas a D.L. persistirem, devemos desprezar todo seu conteúdo e assumir a impossibilidade de conhecer diversos detalhes das filosofias dos milésios, pitagóricos, eleatas e dos chamados 'socráticos menores', por exemplo, algo que dificilmente se concederia, $\left(4^{\circ}\right)$ porque D.L. em muitos dos casos, como na própria 'Vida de Pirro', cita suas fontes, muitas delas contemporâneas e comensais do biografado, fontes que, ademais, podem ser comparadas com outras, gerando exegeses bastante satisfatórias, ainda que longe de inequívocas, aliás, como parece ser tudo na filosofia.

\footnotetext{
44 'GAZZINELli, G. G. A Vida Cética de Pirro. São Paulo: Edições Loyola, 2009'.

45 Introdução de Mário da Gama Kury à sua tradução de D.L. (Brasília: Editora UnB, 2009), segunda edição, p. 09.
} 
Ademais, como nos indica A. A. Long ${ }^{46}$, se "o estilo anedótico de Diógenes Laércio é muitas vezes um obstáculo à transmissão de informações filosóficas", por outro lado, em alguns casos, "aforismos devem ser entendidos como veículos essenciais". Long refere-se especificamente ao cão Diógenes de Sínope, que

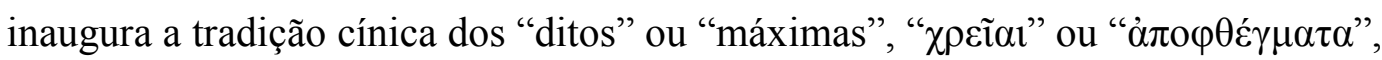
que eram transmitidos em coletâneas e que serviram de matéria-prima para compiladores como D.L. Mas, após Diógenes de Sínope, tem-se a larga difusão

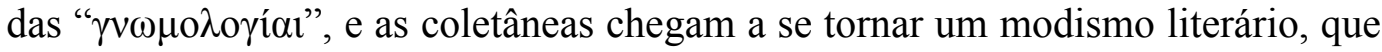
infelizmente só conhecemos de segunda mão, mas que chegou até Epicteto e Luciano $^{47}$, por exemplo. Assim, é possível que também houvesse $\chi \rho \varepsilon i ̃ \alpha$ sobre Pirro, já que elas passaram a se aplicar a todo filósofo que estava inserido numa tradição pós-socrática e Helenística, "uma tradição reconhecivelmente grega um filósofo que caminhava e falava" e que deveria ser compreendido por sua ação prática, registrada em anedotas que narram suas supostas atitudes diante de obstáculos corriqueiros.

Mas não nos alonguemos mais nessa altercação e passemos adiante para empreendermos uma análise passo a passo de D.L. IX 61-71, seguiremos, salvo em poucas ocasiões, a tradução bilíngue espelhada grego/português de Gazzinelli, que utilizou o texto grego estabelecido por Long ${ }^{48}$. Assim:

Pirro de Élida era filho de Pleistarco, segundo narra Dioclés. Como disse Apolodoro, nas Crônicas, primeiro foi pintor e escutou [as aulas] de Brisson [ou] de Estilpo e, depois, de Anaxarco, de acordo com Alexandre, nas Sucessões. Tendo acompanhado o último por toda parte, entrou em contato com os gimnosofistas, na Índia, e com os magos [persas]. (D.L. IX, 61).

Uma passagem sem maiores problemas. Atentemos para a suposta filiação atomista de Pirro, sob Anaxarco, com quem teria visitado os gimnosofistas (provavelmente jainas) na Índia ${ }^{49}$, e também para as fontes: o cínico biógrafo de filósofos, Dioclés de Magnésia (circa 75 a.C.) que somente fornece o nome do pai

\footnotetext{
${ }^{46}$ Todas as citações nesse parágrafo são de: 'LONG, A. A. A tradição socrática: Diógenes, Crates e a ética Helenística. In: GOULET-CAZÉ, M-O; BRANHAM, R. B. (orgs.). Os cínicos: o movimento cínico na Antiguidade e seu legado. São Paulo: Loyola, 2007'.

${ }^{47}$ Ver: 'GRIFFIN, M. Cinismo e romanos: atração e repulsa. In: GOULET-CAZÉ, M-O; BRANHAM, R. B. (orgs.). Os cínicos: o movimento cínico na Antiguidade e seu legado. São Paulo: Loyola, 2007'.

48 'LONG, H. S. Diogenis Laertii vitae philosophorum. Oxford: Oxford University Press, 1964'; vol. 2.

${ }^{49}$ Para mais ver nosso: 'BRITO, R. P. Pirro e Índia: similaridades entre pirronismo e jainismo. In: Revista Alétheia, vol. 1/2, janeiro a julho de 2011'.
} 
de Pirro, algo importante por razões censitárias, porque assim poder-se-ia confirmar a cidadania de Pirro em Élida; e Apolodoro que, ou foi o gramático ateniense discípulo dos estoicos Diógenes da Babilônia e Panécio de Rodes, e do gramático Aristarco da Samotrácia - por sua vez discípulo do gramático e bibliotecário alexandrino Aristófanes, que compilou Homero e criou o sistema de inflexão usado no grego para auxiliar na pronúncia —, ou foi o filósofo epicurista

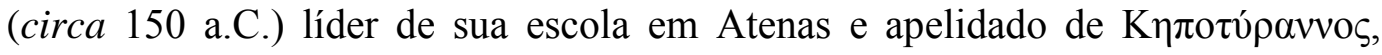
dada a supremacia que o epicurismo atingiu sob sua liderança. Mas considerando o fato de que nosso Apolodoro em D.L. IX 61 escreveu 'Crônicas', provavelmente trata-se do epicurista, além disso, sabe-se que havia certa admiração de Epicuro por Pirro, o que justificaria o fato de que o que Apolodoro nos diz aqui sobre Pirro vincula-se à hipótese de que Pirro teve uma vida perfeitamente normal, desempenhando inclusive o exercício de uma $\tau \dot{\varepsilon} \chi v \eta$ : a $\zeta \omega \gamma \rho \alpha \varphi$ ía. Ao passo que se a fonte fosse outra (estóica ou talvez acadêmica, por exemplo) não perderia a oportunidade de dizer que Pirro viveu de modo estranho por conta de seu viver/filosofar. A terceira fonte é Alexandre Polyhistor, autor das $\Delta 1 \alpha \delta$ o $\alpha$ ĩ no séc. I a.C. Devemos observar que as três fontes aqui citadas são pelo menos cento e vinte anos posteriores a Pirro.

Continuemos com o passo D.L. IX 61:

Disto decorre [ser o pirronismo] o mais nobre filosofar: por ter introduzido em seu modo de vida os estados de inapreensibilidade e de suspensão de juízo (

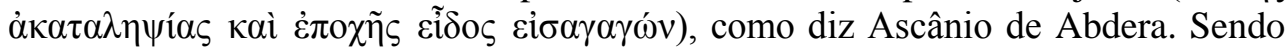
assim, nada dizia ser nem belo, nem feio, nem justo, nem injusto, mas, igualmente, sobre todas as coisas, afirmava nada ser em verdade ( $\dot{\alpha} \lambda \eta \theta \varepsilon$ cí $_{\text {), }}$ mas todos os homens agirem segundo a convenção e o costume; pois

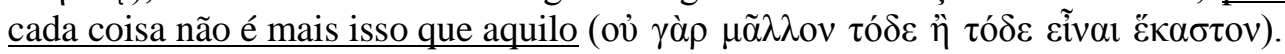

Aqui destacamos primeiramente a fonte: Ascânio de Abdera, discípulo direto de Pirro que atribui ao modo de vida do mestre — ou seja, em âmbito prático, e não

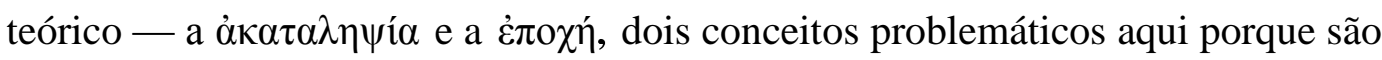
vinculados diretamente ao estoicismo, cujo fundador, Zenão de Cítio (circa 334260 a.C.), é em torno de trinta anos mais jovem que Pirro. Assim sendo, das quatro uma: ou Ascânio está introjetando o vocabulário estoico em sua própria interpretação da filosofia de seu mestre; ou está assumindo deliberadamente esse vocabulário; ou está pretendendo a precedência de Pirro no uso do vocabulário e, portanto, a antecedência de Pirro a Zenão e ao estoicismo; ou de fato Pirro 
utilizou esse vocabulário porque talvez já estivesse disponível, ou porque talvez fosse mesmo seu criador.

Desejamos descobrir um caminho nessa discussão até então aporética,

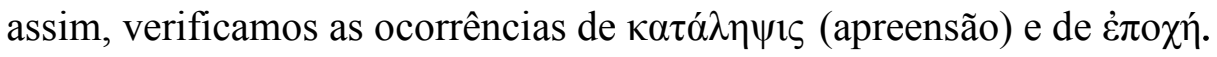

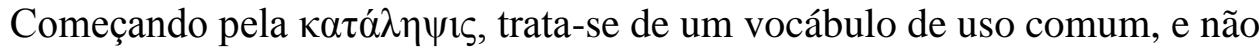
exclusivo do jargão filosófico, desse modo, temos cerca de catorze ocorrências segundo $\mathrm{LSJ}^{50}$. Começando pelos usos de âmbito militar, algumas dessas ocorrências são: uma em Tuc. 3.33, significando "tomar de assalto"; uma em Ar.Nu. 318 com o mesmo significado; uma em Isoc. 9.69, referindo-se ao direito do rei de "tomar posse" de algo; em Platão, Górg. 455c, e Rep. 526d, ambos falando sobre a tarefa dos guerreiros de erguer acampamentos e "ocupar" lugares; o mesmo significado militar aparece em Dem. 19.21 e em App BC 4.14.

Agora, os usos de âmbito médico: em Hp. Off. 9 e 11, tratando do ato de "segurar" bandagens para fazer curativos, e também "segurar" os instrumentos médicos; em Gal. 6. 152; 17. 423, referindo-se à "contenção" da respiração e do esperma, respectivamente.

Há também uma ocorrência musical que se refere à pausa que se faz ao “segurar"-se as cordas da lira em Ar.Nu. 317.

No âmbito filosófico estrito, onde $\kappa \alpha \tau \alpha ́ \lambda \eta \psi \imath \varsigma$ é um conceito que se refere à apreensão e é utilizado, então, como critério epistemológico (porque propicia a adesão à verdade) e como critério ético (porque propicia a adesão à ação correta $\mathrm{e}$ conforme a verdade), temos as seguintes ocorrências: Luc. Par. 4, referindo-se à "apreensão" mental dos objetos celestes; em Luc. Herm. 81, referindo-se à “certeza" advinda pelo uso correto das sensações; em Vit. Par. Vida de Cícero 40, referindo-se à introdução do conceito à língua latina por Cícero.

Em todos os casos de uso filosófico remete-se à filosofia estóica, não há

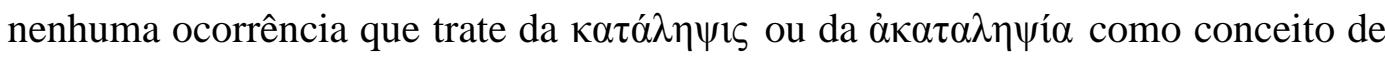
Pirro, exceto a citação de Ascânio de Abdera por Diógenes em D.L. IX 61. Temos assim razões suficientes para questionar a atribuição do uso do conceito de

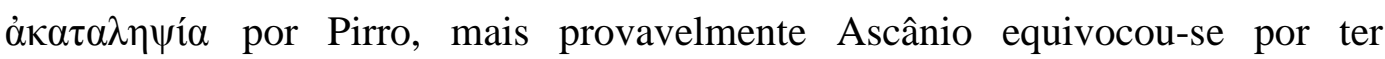
introjetado um conceito originariamente estoico, deixando-o aparecer em um

50 'LIDELL, H. G., SCOTT, R. A Greek-English Lexicon. revised and augmented throughout by. Sir Henry Stuart Jones. with the assistance of. Roderick McKenzie. Oxford: Clarendon Press, 1940.' Doravante sempre citado como LSJ. 
comentário sobre Pirro; ou voluntariamente afirmou a precedência de Pirro no uso do conceito, antes mesmo de Zenão. De todo modo, trata-se de um engano.

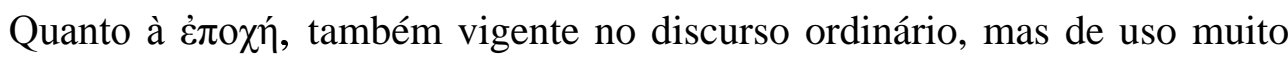
mais amplo que a $\kappa \alpha \tau \alpha ́ \lambda \eta \psi 1 \varsigma$ acima, tínhamos cerca de trezentas ocorrências extraídas de LSJ e da base de dados Diógenes quando desistimos de contar, indo desde a "retenção" de esperma no uso médico (Gal. 8. 420), passando pela "suspensão" de pagamento no uso financeiro (PRyl. 214. 34), e também pela "suspensão" das alianças no âmbito da diplomacia e da estratégia militar (Plb. 10.23.4, e 38.11.2), chegando até o uso filosófico que nos interessa aqui e o único sobre o qual falaremos, cujas ocorrências mais significativas, além de Sexto Empírico e Diógenes Laércio, são: Metrod.Herc. 831.6, SVF II. i. 2. 71-81, Acad.

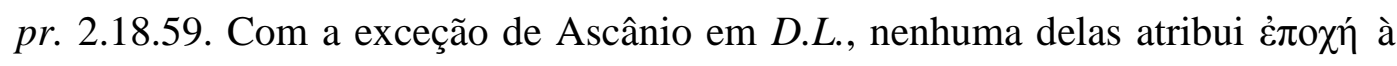
Pirro, assim, pensamos que também essa atribuição se deve a um equívoco de Ascânio de Abdera.

Retornaremos mais adiante à questão sobre a apropriação desses conceitos pela filosofia. Passemos agora às asserções, também de Ascânio, de que Pirro (1)

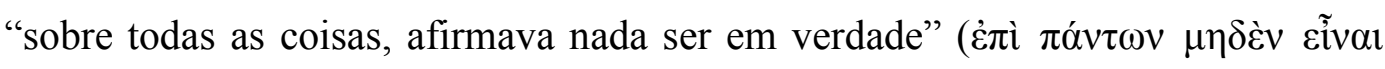

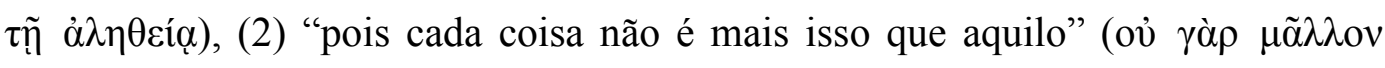

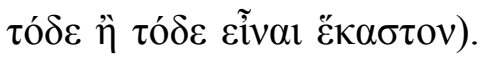

Começando pela segunda asserção (2), não há maiores problemas nela, trata-se do uso de uma expressão (ov̉ $\mu \tilde{\alpha} \lambda \lambda$ ov) consagrada nos ceticismos Antigos (especialmente no pirrônico) e que ocorre (mais a frente) tanto em D.L. IX 75, quanto em P.H. I, 188-192, por exemplo. Voltaremos à expressão depois, nesse momento vale ressaltar que ou Ascânio está, novamente, atribuindo retroativamente um vocabulário cético mais posterior à Pirro, ou Pirro de fato já dispunha desse vocabulário. Nossa opção é pela segunda hipótese, considerando que Pirro era originalmente um atomista e que passou, portanto, algum tempo em Abdera, terra natal de Leucipo e Demócrito — os dois 'fundadores' dessa doutrina —, bem como do próprio Ascânio, e cidade sede dos atomistas, que já dispunham dessa expressão em seu vocabulário, como podemos ver em um fragmento doxográfico sobre os atomistas, curiosamente em P.H. I 213-215, passagem em que Sexto Empírico está a elucidar as diferenças e semelhanças entre o pirronismo e o atomismo: “... Demócrito, de acordo com alguns, infere que [o mel] não é na realidade nem doce e nem amargo, e pronuncia na sequência a fórmula "não 
mais" (ov̉ $\mu \tilde{\alpha} \lambda \lambda$ ov), que é uma fórmula cética". Os céticos, contudo, prossegue Sexto, utilizam a expressão diferentemente do uso atomista, porque usam-na para

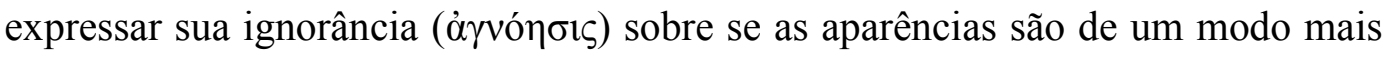
do que outro, com conotação comparativa (de fato, $\mu \tilde{\alpha} \lambda \lambda$ ov pode ser usado como o comparativo de $\left.\mu \alpha \lambda^{\lambda} \alpha\right)^{51}$. Ao passo que os atomistas usam-na para denotar que a verdade não está no muito, no $\mu \alpha \kappa \rho o ́ s$, porque o mundo macro, conforme se faz percebido aos sentidos, de forma passiva, é tão-somente fruto de arranjos de átomos, e os átomos são, eles sim, verdadeiros. Portanto, a verdade não está no

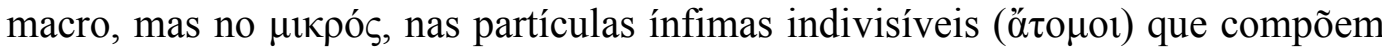
o cosmos e que não podem ser percebidas pelos sentidos, mas são inteligíveis.

Considerando isso, podemos voltar à asserção dogmática negativa, que Ascânio de Abdera atribui a Pirro, (1) "sobre todas as coisas, afirmava nada ser

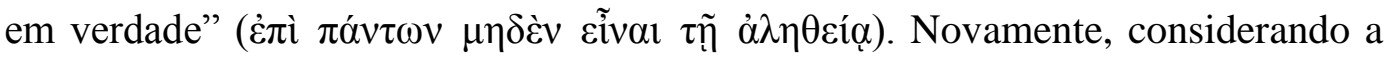
filiação atomista de Pirro, é perfeitamente plausível que ele tenha dogmatizado, ainda mais se levarmos em conta os fragmentos de Demócrito ${ }^{52}$ sobre o conhecimento onde ele, assim como Pirro, assere a sua impossibilidade:

Frag. D15 (D.L. IX, 72): Quanto à realidade, não sabemos nada; pois ela está nas profundezas.

Frag. D16 (Adv. Log. I, 135): Por convenção o doce e por convenção o amargo; por convenção o quente e por convenção o frio; por convenção a cor; mas na realidade os átomos e o vazio.

Frag. D17 (Adv. Log. I, 136): Na verdade, não conhecemos nada firmemente, mas somente o que muda de acordo com a condição do corpo e das coisas que [nele] entram e põem-se contra ele.

Frag. D18 (Adv. Log. I, 136): Que na realidade não sabemos que tipo de coisa cada coisa é ou não é foi demonstrado muitas vezes.

Frag. D19 (Adv. Log. I, 137): Por esse princípio, o homem deve saber que foi posto fora da realidade.

Frag. D20 (Adv. Log. I, 137): Esse argumento também demonstra que na realidade não sabemos nada sobre nada, mas a opinião de cada pessoa é algo que flui.

Frag. D21 (Adv. Log. I, 137): Ainda, estará claro que conhecer que tipo de coisa cada coisa é na realidade é algo impossível.

${ }^{51}$ Se usarmos a versão do pseudo-Aristóteles para o 'Tratado do não ser', de Górgias (in: 'De Melisso, Xenófanes e Górgias', apud. Cassin, op. cit.), veremos também lá o uso da fórmula ov̉

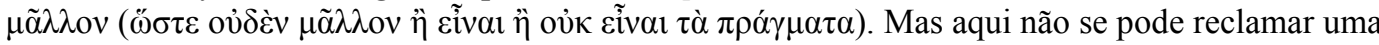
antecedência a um tema pirrônico sextiano, uma vez que assim fosse Sexto Empírico não hesitaria em utilizar a versão de pseudo-Aristóteles, mas ele não o faz. Mais provável é que Sexto nem mesmo conhecesse essa versão. Apesar disso, considerando que a fórmula é constante na oratória contemporânea a Górgias, é possível que Pirro, ao usá-la estivesse remetendo-se ao uso atomista da fórmula e ao uso sofístico, simultaneamente, mas mesmo essa interpretação é frágil se levarmos a sério os relatos doxográficos que narram que Pirro era avesso às disputas sofísticas.

${ }^{52}$ Para mais ver a melhor, por ser a mais atual, compilação dos fragmentos dos atomistas: 'TAYLOR, C. C. W. (org. \& trad.). The atomists: Leuccipus and Democritus, fragments. In: The Phoenix Presocratics. Toronto: University of Toronto Press, 2010.' 
Passemos agora ao passo D.L. IX 62:

Seguindo isso também na vida, não se desviava nem se guardava de coisa alguma que, por ventura, se encontrasse em seu caminho - carros, cães ou despenhadeiros

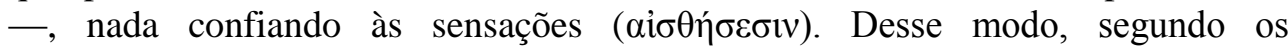
testemunhos de Antígono de Caristo, era salvo pelos conhecidos que o acompanhavam. Enesidemo, por seu turno, dizia que ele filosofava segundo o

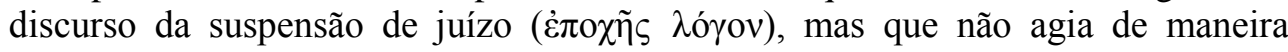

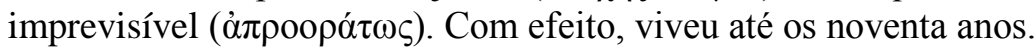

Essa parte do passo IX 62 de D.L. é bastante emblemática do que dissemos outrora sobre as biografias antigas: mais do que relatar a vida do biografado, elas servem para enaltecer ou depreciar sua doutrina, seja elogiando sua atitude prática, seja reprovando-a ou afirmando sua inviabilidade, ainda mais se o biografado for um filósofo que, como Sócrates ou Pirro, pensa que filosofia e vida se confundem. Dessa forma, temos aqui claramente duas versões antagônicas sobre a 'Vida de Pirro', uma de Antígono de Caristo e outra de Enesidemo de Cnossos. Mas Antígono, apesar de contemporâneo de Pirro, era muito mais jovem do que ele e deixou-se cativar por Arcesilao e pelo ceticismo acadêmico, tendo sido seu discípulo. Assim, a versão de Antígono está longe de ser desinteressada, e, ainda, se seu interesse for depreciativo, a oposição entre a academia e os discípulos imediatos de Pirro começa a desenhar-se mais cedo do que esperávamos, antes, portanto, da querela sobre o critério dogmático acadêmico ( $\pi \bullet \alpha v o ́ \varsigma)$ que envolveu os contemporâneos de Clitômaco (Fílon de Larissa e Enesidemo de Cnossos) que culminou com a deserção do último e o reavivamento do pirronismo (falaremos sobre isso mais adiante). Por outro lado, Enesidemo, cerca de três séculos posterior a Pirro, não pôde conhecê-lo e, assim como Antígono, tinha bons motivos para ser imparcial, afirmando que Pirro viveu a vida de um homem comum, que sua filosofia/vida é possível na prática, porque pretendia revivê-la em oposição ao dogmatismo eclético (meio estoico e meio peripatético) instaurado na academia por Fílon. Em suma, a discussão aqui entre Antígono e Enesidemo é aporética, não por que seus relatos sejam igualmente persuasivos e prováveis, pelo contrário, são ambos dissuasivos e improváveis. Então, temos de desconsiderar aqui a pretensão à verdade, rejeitando ambos os relatos. Contudo, o único a asserir a apraxía de Pirro é Antígono, rejeitado, mas Enesidemo, embora também rejeitado, não é o único a asserir a possibilidade 
dessa 'vida'. Desse modo, se excluirmos Antígono e Enesidemo, restam-nos as fontes que alegam que Pirro viveu uma vida comum.

Ademais, se rejeitamos Enesidemo como muito tardio e imparcial,

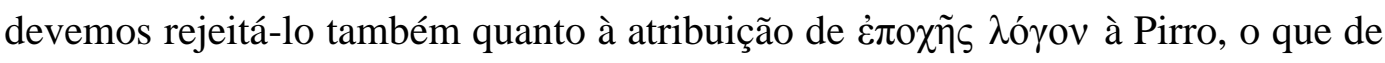
fato está de acordo com o que fizemos anteriormente na citação de Ascânio de Abdera por Diógenes no passo D.L. IX 61.

Sigamos com o passo D.L. IX 62-63:

Antígono de Caristo conta, em seus escritos sobre Pirro, estas coisas: no início era desconhecido, pobre e pintor; preservam-se, no ginásio de Élida, uns corredores com tochas [pintados por ele], que são medianos.

Isolava-se da sociedade ( $\dot{\varepsilon} \kappa \pi \alpha \tau \varepsilon i v)$ e vagava solitário, raramente aparecia aos de casa. Agia assim por ter escutado um indiano reprovar Anaxarco [dizendo] que não poderia ensinar alguém a ser bom frequentando a corte real. Sempre falava na mesma compostura: se alguém o deixasse no meio de sua fala, para si mesmo concluía o discurso (ainda que tenha sido inquieto quando mais novo). Muitas vezes, narra [Antígono], afastava-se de casa sem avisar ninguém e vagava com quem quer fosse. E, quando Anaxarco caiu em um pântano, seguiu [andando] e não o socorreu. Aos que o censuravam, o mesmo Anaxarco elogiou sua indiferença

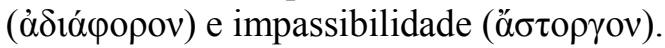

O relato ainda é de Antígono de Caristo, que persiste na demonstração do viver

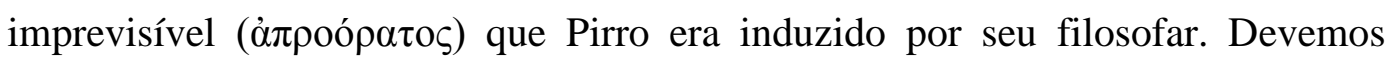
ressaltar que em nenhum momento há a acusação de apraxía sobre Pirro, mas sim de imprevisibilidade (nosso correlato à apraxía em D.L. IX 61-71) que se deixa transparecer no isolamento, no vagar e falar solitário, mas já argumentamos que Antígono não é confiável, por outro lado, mesmo que se argumente a favor dessa fonte, há que se notar que o próprio Antígono diz que a imprevisibilidade do comportamento de Pirro deve-se à exacerbação das consequências éticas do atomismo, expressas pelo vocabulário ético originalmente atomista: $\alpha \delta$ ¿ $\alpha \varphi \rho \operatorname{cí}^{\alpha}$ e

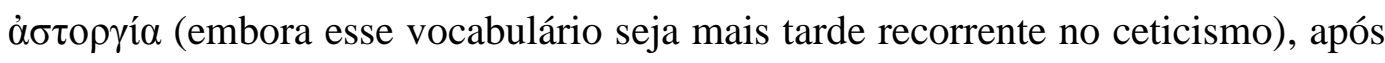
a suposta ida com Anaxarco à Índia.

Não podemos deixar de mencionar algo que possivelmente está implícito na acusação de imprevisibilidade feita por Antígono. O vocábulo que traduzo aqui

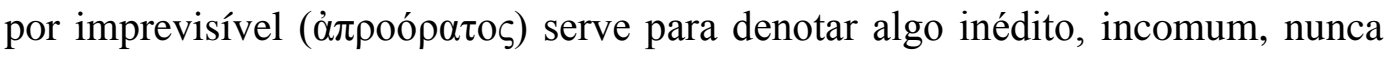
antes visto, e é pouco utilizado. Mas, uma palavra mais corriqueira que pode portar o mesmo significado e ser traduzida da mesma forma é à $\varphi \rho o \sigma u ́ v \eta$, que

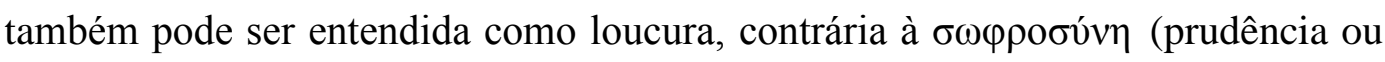
sabedoria). Assim, se Pirro, segundo Antígono, aprendeu o comportamento 
imprevisível na Índia, talvez a afirmação implícita aqui seja que o modo bárbaro de vida aprendido seja insano, ou conduza à insanidade, de toda forma, algo que dificilmente poderia ser considerado um bem viver, mas que, destaco, origina-se não em uma postura cética, mas em uma exacerbação das consequências éticas do atomismo Helenístico, que é uma forma de dogmatismo negativo em teoria do conhecimento.

Vejamos o passo D.L. IX 64:

Certa vez, foi surpreendido quando falava consigo mesmo e, ao lhe perguntarem o motivo, disse que treinava para ser [um] homem de bem. Nas investigações

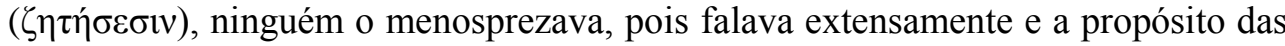
perguntas. Por isso, também Nausífanes, quando era jovem, deixou-se cativar por ele. Teria dito, então, que se deveria seguir a disposição de Pirro, mas os discursos dele próprio. Nausífanes contava, com frequência, que também Epicuro se maravilhara com a maneira de viver de Pirro; quando era seu discípulo, perguntava continuamente sobre ele. Pirro foi de tal maneira honrado pela sua pátria, que lhe ordenaram sumo sacerdote e, por sua causa, votaram a isenção de impostos para todos os filósofos.

Passagem também sem problemas, destacamos outro relato em que Pirro fala sozinho, mas agora treinando discursos com vistas a se tornar um homem de bem através do reto uso da oratória, um exercício nada extravagante e bastante

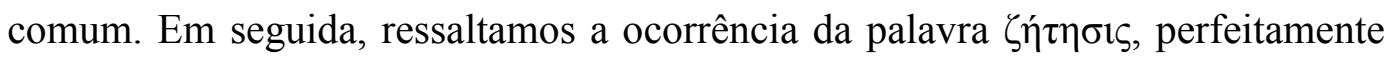
plausível, tendo em vista que já era usada com o mesmo sentido que aparece aqui (investigação) em âmbito histórico (ver: Hist. 2.44, 6.118; Tuc. 1.20, 8.66), trágico (ver: Trach. 55), jurídico (ver: Lys. 12.30, Aeschin. 1.43), e, finalmente, filosófico (Teet. 196d; Crat. 406a; Apol. 29c; Tim. 47a; Fedr. 244c; Fed. 66d),

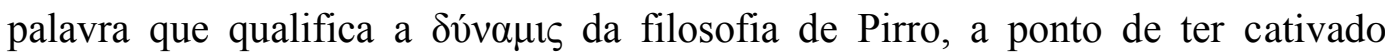
Nausífanes, seu discípulo direto e nossa fonte aqui, que também foi mestre de Epicuro que, por isso, perguntava-lhe constantemente sobre Pirro. Ademais, Nausífanes é mais um a atestar a vida comum e a piedade de um Pirro que teria, inclusive, chegado a sumo sacerdote em Élida. Finalmente, outro ponto interessante na passagem é o relato de que, em sua pátria, em sua homenagem, "votaram a isenção de impostos para todos os filósofos", mas nada indica que foi o próprio Pirro quem propôs isso, ou ainda que ele tenha votado, nem mesmo a favor, fato que se liga ao importante tópico do 'afastamento das coisas públicas', ou $\alpha \pi \rho \alpha \gamma \mu$ 
Teve, pois, muitos imitadores de sua vida alheia às coisas públicas

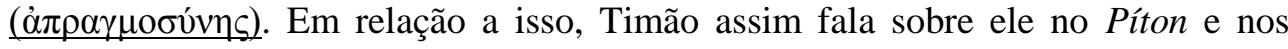
Silloi:

Ó velho, ó Pirro, como e a partir de que encontraste uma fuga

da servidão às opiniões e vacuidade dos sofistas?

E como te libertaste ( $\dot{\alpha} \pi \alpha \theta \dot{n} s)$ dos grilhões de todo estratagema e da persuasão $(\pi \varepsilon 1 \theta 0 \tilde{c} \varsigma)$ ?

Não te ocupaste destas coisas inquirir ( $\mu \varepsilon \tau \alpha \lambda \lambda \tilde{\eta} \sigma \alpha \imath)$ : que sopros correm a Hélade, de onde [vem] cada coisa e o que alcança. ${ }^{53}$

$\mathrm{E}$, novamente, nos Indalmoi:

Isso, ó Pirro, meu coração deseja aprender,

como, sendo mortal, facilmente conduzes uma vida tranquila (i்ovíns),

único guiando os mortais à maneira de um deus. ${ }^{54}$

Os atenienses honraram-no com a cidadania, segundo disse Díocles, por ter aniquilado o trácio Cótis.

Viveu piamente com a irmã, que era parteira, segundo atesta Eratóstenes em Sobre a riqueza e a pobreza, onde se conta que Pirro levava ao mercado galinhas e quiçá porquinhos e que limpava a casa indiferentemente (ådo $\alpha \varphi \rho \omega \varsigma)$. Diz-se que, certa

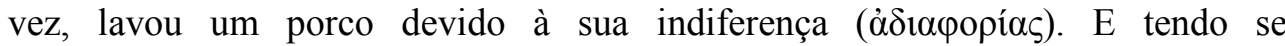
encolerizado com alguém por conta de sua irmã — que se chamava Filista -, disse

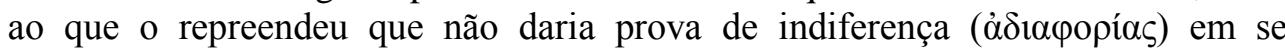
tratando de uma mulher. E quando se assustou, tendo sido atacado por cães, respondeu ao que o acusava que é difícil despir-se completamente do humano. Contra as coisas, é necessário, primeiramente, se possível, lutar pelas ações e, se não o for, pelo discurso.

No fim do passo D.L. IX 64, cuja fonte não podemos saber ao certo se é Nausífanes ou Timão - mas, considerando que ambos foram convivas de Pirro, a incerteza não traz maiores problemas — há um relato do comportamento político de Pirro em que ele teria levado uma "vida alheia às coisas públicas" ( $\dot{\alpha} \pi \rho \alpha \gamma \mu \sigma \sigma v v \eta \varsigma)$, um tópico importante que demanda nossa atenção.

De acordo com LSJ, a $\alpha \pi \rho \alpha \gamma \mu o \sigma u ́ v \eta$ consiste na abstenção da participação nas coisas públicas, a ocorrência mais antiga da palavra é Ar.Nu. 1007; em Tuc. 1.32, os corcireus, ao pedirem ajuda à Atenas, desculpam-se pelo longo afastamento das coisas públicas, a $\alpha \dot{\pi} \rho \alpha \gamma \mu$ ớvฑ que os distanciou dos vizinhos; em Mem. 3.11.16, Sócrates faz chacota de si mesmo, ironizando aqueles que o

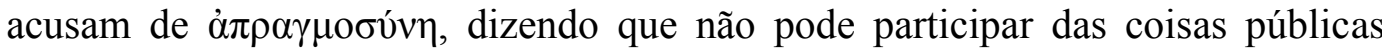
porque tem a vida pessoal muito atribulada, todos esses são empregos pejorativos do vocábulo e denotam uma espécie de irresponsabilidade social. Há também um uso que aparece em Dem. Or. 21.141 como um termo legal originariamente ateniense $^{55}$, podendo ter uma conotação positiva que indicaria o recolhimento do

\footnotetext{
${ }^{53}$ Fr. 48 Diels.

${ }^{54}$ Fr. 67 Diels. Compare com Adv. Gram. 305.

${ }^{55}$ Ver: 'TODD, S.C. A Glossary of Athenian Legal Terms. In: Lanni, A (ed.), Athenian Law in its Democratic Context (Center for Hellenic Studies On-line Discussion Series). Republicado em
} 
sujeito que busca a reflexão filosófica, oposta à intranqüilidade de uma vida com $\pi \circ \lambda v \pi \rho \alpha \gamma \mu \circ \sigma v ́ v \eta$ (curiosidade excessiva, mas que também pode ser oficiosidade; intrometimento em diversos âmbitos, Rep. $444 \mathrm{~b}$, por exemplo: as intromissões de Atenas em outras cidades, quando do seu imperialismo no séc. V, Plb 5.75.6).

No contexto da Guerra do Peloponeso, quando do pedido de ajuda da cidade de Segesta à Atenas, contra Selinonte, que contava com o apoio de Siracusa, em 415-413 a.C., Alcibíades, o amigo de Sócrates, decididamente a favor da interferência de Atenas na política siracusana, para expandir o império ateniense, dirigiu-se à assembleia e exortou o povo à apoiar a intervenção (que

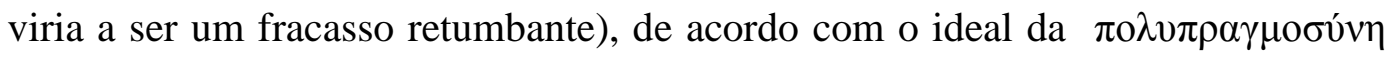
que marcava as relações de Atenas com seus vizinhos, contra os apelos de Nícias que, por seu turno, aconselhava cautela, mas que foi acusado por Alcibíades de

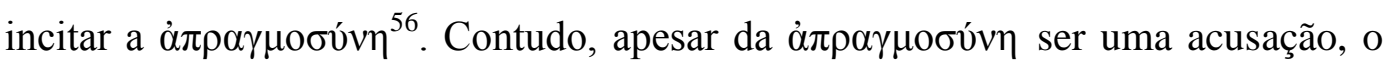
acusador Alcibíades - após a incriminação pela profanação dos bustos de Hermes, da derrota de Atenas perante a frota unida siciliana, de sua traição ao fugir para Esparta e, sobretudo, da verificação de que, no fim das contas, os vaticínios de Nícias estavam corretos - passa a ser um exemplo negativo, e os atenienses parecem ter cada vez mais optado por absterem-se das decisões, por desilusão com as coisas públicas, talvez, e assim, cada vez mais a $\dot{\alpha} \pi \rho \alpha \gamma \mu o \sigma u ́ v \eta$ se tornou uma postura política corriqueira entre a população, mas como sinônimo

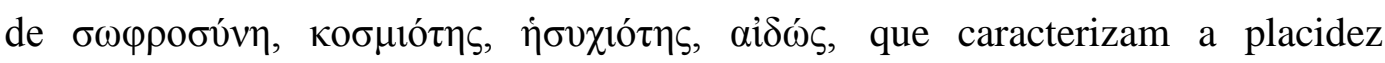

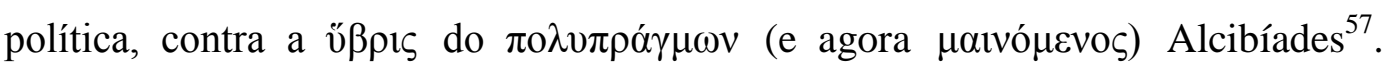
Além disso, talvez se recordando das representações que Aristófanes e Xenofonte haviam feito de Sócrates e de sua relação com as coisas da cidade, o povo ateniense passou a evocá-lo como um defensor da $\alpha \dot{\pi} \rho \alpha \gamma \mu \sigma \sigma v ́ v \eta$, que se tornou a marca dos cínicos ${ }^{58}$, uma postura alegadamente socrática, portanto, e largamente

BLACKWELL, C.W (ed.). Dēmos: Classical Athenian Democracy (A. Mahoney and R. Scaife, edd., The Stoa: a consortium for electronic publication in the humanities [www.stoa.org]) edição de março 16, 2003.

${ }^{56}$ Ver: 'JONES, P. V. (org.). O mundo de Atenas, uma introdução à cultura clássica ateniense. São Paulo: Martins Fontes, 1997', especialmente o capítulo I; e 'CARTER, B. L. The quiet Athenian. Oxford: Claredon Press, 1986'.

${ }^{57}$ Ver: 'SCHOFIELD, M.; ROWE, C. The Cambridge history of Greek and Roman political thought. Cambridge: Cambridge University Press, 2000'.

${ }^{58}$ No caso dos cínicos, a $\dot{\alpha} \pi \rho \alpha \gamma \mu$ Sobre o cínico Diógenes de Sínope, por exemplo, diz-nos D.L. que vivia "sem cidade, sem lar, banido da pátria, mendigo, errante, na busca diuturna por um pedaço de pão" (D.L. VI 38, citando uma tragédia anônima, Fr. 984 Nauck). Para mais ver: 'NAVIA. L. E. Diógenes, o cínico. São Paulo: Odysseus, 2009'. É possível que o sinopense tenha herdado sua versão da $\alpha \pi \rho \alpha \gamma \mu$ oóv $\eta$ de 
difundida posteriormente, no conturbado período Helenístico, sem quaisquer conotações pejorativas $^{59}$.

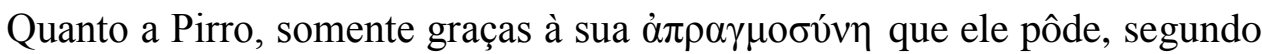
Timão, seu discípulo direto, em seus Píton e Silloi, "encontrar uma fuga da servidão às opiniões e vacuidade dos sofistas" que eram abundantes nas ágoras, libertando-se dos seus "estratagema [s] e da persuasão". Por sua vez, há um trocadilho nessa passagem do poema de Timão (Fr. 48, Diels), evidente na escolha do verbo $\dot{\alpha} \pi \alpha \theta \dot{\varepsilon} \omega$, que segundo LSJ significa “estar livre", conjugado aqui na segunda pessoa singular do imperfeito indicativo ativo dórico-eólico contrato (= $\grave{\alpha} \pi \alpha \theta \eta ́(\zeta)$, vocábulo que, se entendido como substantivo ou adjetivo nominativo masculino singular da primeira declinação, ao invés de entendido como verbo,

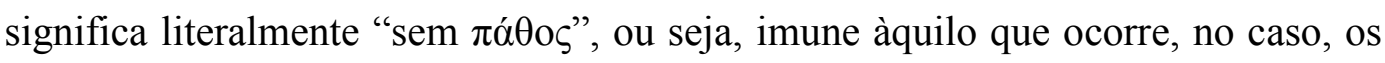
debates sofísticos, não se deixando persuadir, ao recolher-se na instância dos seus afazeres domésticos, evitando inquietar-se com os problemas cívicos (outra acepção da $\alpha \pi \rho \alpha \gamma \mu$

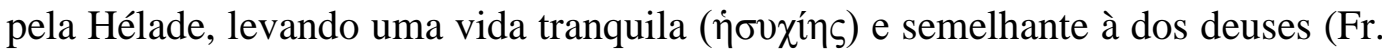
67, Diels). Interessa-nos aqui notar também que Timão não usava a palavra $\grave{\alpha} \tau \alpha \rho \alpha \xi i ́ \alpha$ para referir-se à quietude de Pirro, seu mestre, mas sim $\dot{\eta} \sigma v \chi i ́ \alpha$, porque

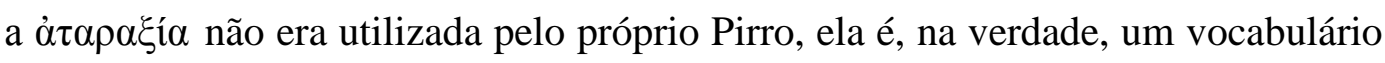
originalmente epicurista, muito retroativamente atribuído por Estobeu (Flori. 7.31) a Demócrito. Sobre a afirmação de que os atenienses deram a Pirro a cidadania, que aparece no fim do passo D.L. IX 65, trata-se de uma confusão que Diógenes faz com o episódio do assassinato do tirano Cótis, pelas mãos de Pito, um discípulo de Platão, e não por Pirro.

uma fonte socrática, intermediária entre ele e o próprio Sócrates, Antístenes, que provavelmente

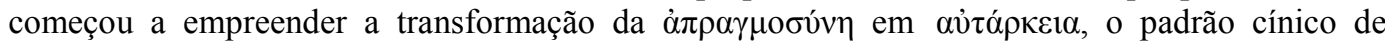
virtude: "[Antístenes,] Vestindo apenas um manto, descalço, com uma sacola de esmolas no ombro, barba e cabelo em desalinho, segurando um cajado, buscava, por meio de seu exemplo, e não oferecendo nenhum outro fator de atração afora essa aparência miserável, conduzir os seres humanos à simplicidade da natureza." (Antisthène, in: 'Dictionnaire des Sciences Philosophiques, ed. A. Frank. Paris: Librarie Hachette, 1885 ', p.76.) O antecessor filosófico de todos os que defendem o abandono das coisas da cidade, em uma versão mais moderada - como a

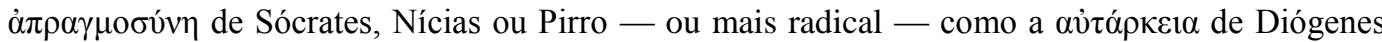
de Sínope - foi Heráclito: "Heráclito de Éfeso (...) acabou por se tornar um misantropo

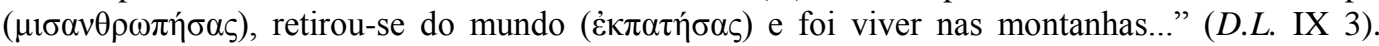
Novamente, por mais que se alegue que em D.L. não há a preocupação com a verdade, contudo, há a expressão de um senso comum que, de fato, achava que a marca distintiva de uma possível "vida" heraclítica seria a $\mu 1 \sigma \alpha v \theta \rho \omega \pi i ́ \alpha$.

${ }^{59}$ Ver: 'REEVE, C. D. C. Socrates in the Apology: an essay on Plato's Apology of Socrates. Indianápolis: Hackett Publishing Company, 1989'. 
Segundo o passo D.L. IX 66, cuja fonte é o astrônomo, filólogo e geógrafo cirenáico do séc. III meio estoico e meio acadêmico, Eratóstenes, Pirro "viveu piamente com a irmã", e também executava as enfadonhas tarefas domésticas sem

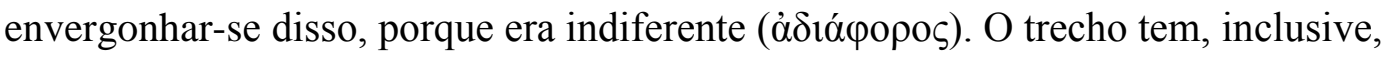
três ocorrências desse vocábulo: em um episódio em que Pirro limpava a casa

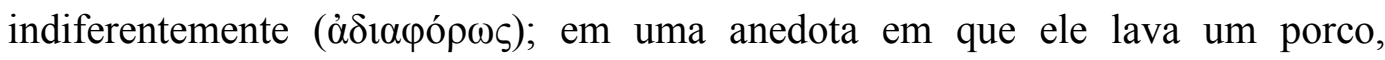
tamanha era sua indiferença ( $\dot{\alpha} \delta 1 \alpha \varphi \rho \operatorname{lí}_{\alpha \varsigma}$ ); e no relato de que ele não conseguiu dar demonstração de indiferença ( $\dot{\alpha} \delta 1 \alpha \varphi \rho \rho i ́ \alpha \varsigma)$ diante de um insulto que sua irmã teria sofrido. Mas Eratóstenes acrescenta que as falhas que ocorrem no

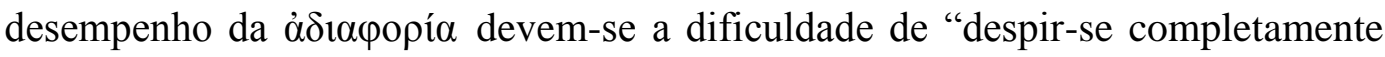

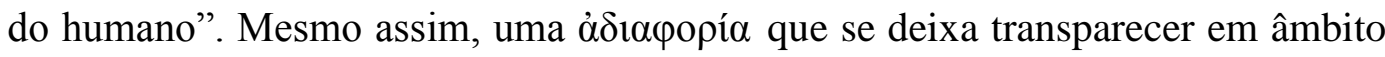
público só pode ser minimamente desempenhada justamente graças ao

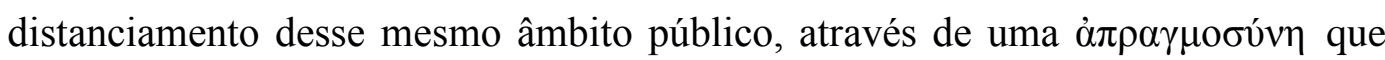
não significa de maneira nenhuma uma inação ou inatividade ( $\alpha \pi \rho \alpha \xi i ́ \alpha)$, porque não há a recusa da ação em si, Pirro desempenhava suas tarefas de âmbito doméstico, limpava a casa, ia ao mercado, ajudava sua irmã, somente há a recusa da ação pública, que, além disso, é parcial, tendo em vista que Pirro foi durante algum tempo ativo em uma $\tau \varepsilon ́ \chi v \eta$, a $\zeta \omega \gamma \rho \alpha \varphi i ́ \alpha$, e provavelmente foi também sacerdote em Élida, atividade para a qual era necessário um recolhimento, certa

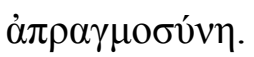

Nos últimos passos sobre a 'Vida de Pirro' em D.L. IX 67-71 (os passos 71108 referem-se a outros temas concernentes ao ceticismo), não há maiores problemas - em 67, 68 e 69 aparecem anedotas sobre Pirro; em 67 aparece sua predileção por Demócrito e Homero, de quem citava versos, segundo Fílon de Atenas; em 69 e 70 aparecem seu legado e as divisões subsequentes entre seus seguidores imediatos, que

[são] zetéticos, por examinarem a verdade de tudo; céticos por investigarem sempre e nunca encontrarem; eféticos pelo estado após o exame, digo, a suspensão de juízo; aporéticos, por estarem em um estado de aporia em relação às próprias [noções], assim como em relação às dos dogmáticos; pirrônicos pelo Pirro...

Embora isso não seja algo totalmente verossímil, tendo em vista que seria preciso

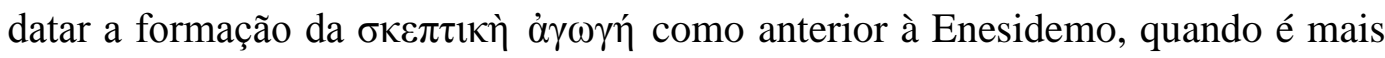
provável que tivesse havido uma dissensão entre os companheiros de Pirro, que teriam se dividido em grupos após sua morte, algo que pode ser presumido pela 
recusa de Teodósio em ser tratado como pirrônico (no fim do passo D.L. IX, 70) - contudo, há no passo 68 a imputação, pelo estoico Posidônio de Rodes (circa 135-51 a.C.), mestre de Cícero, de imperturbabilidade ( $\alpha \tau \alpha \rho \alpha \xi i ́ \alpha)$ à vida de Pirro, como consequência de seu filosofar. Já argumentamos acima contra isso, é preciso então aqui dizer, a nosso favor, que Posidônio é uma fonte deveras tardia quando

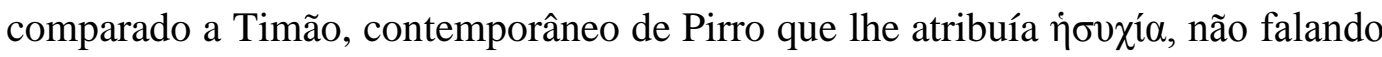

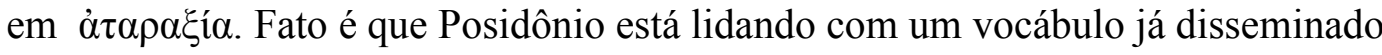
em sua época para designar o tipo de felicidade negativa (como ausência de perturbação) que vem a se tornar vocabulário comum a todas as principais filosofias Helenísticas.

Ora, se estamos corretos em nossa análise, devemos encerrar essa seção observando que:

1- a 'Vida de Pirro' é composta por um amálgama de fontes, contemporâneas ou não ao biografado, mais ou menos interessadas em um tipo de retrato, encomiástico ou depreciativo.

2- Pirro, como todo filósofo atomista, asseriu a impossibilidade do conhecimento, um tipo de dogmatismo negativo, conforme atestado ainda por PE. 14.18.1 - 5 e Adv. Eth. 140 (falando de Timão, que ostentava as mesmas teses que Pirro).

3- Possivelmente, Pirro exacerbou ainda mais as consequências éticas extraídas da física e epistemologia atomistas após ter ido com Anaxarco à Índia.

4- Contudo, mesmo assim não incorreu em nenhum tipo de comportamento inaudito e imprevisível ( $\dot{\alpha} \pi \rho 00 \rho \alpha ́ \tau \omega \varsigma)$.

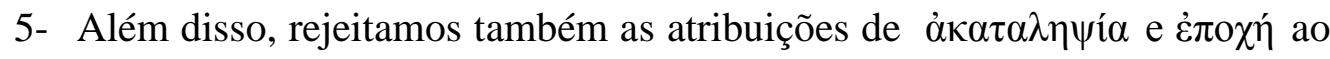
vocabulário de Pirro, bem como de $\dot{\alpha} \tau \alpha \rho \alpha \xi i ́ \alpha$.

6- Por outro lado, a filosofia de Pirro pode ser entendida como uma forma de vida qualificada pelos conceitos de $\alpha \dot{\delta} 1 \alpha \varphi \rho \rho i ́ \alpha$ (indiferença) e $\alpha \sigma \tau o \rho \gamma i ́ \alpha$

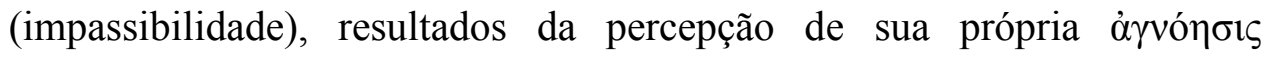
(ignorância, ver Tusc. 5.85), expressa pela fórmula oủ $\mu \tilde{\alpha} \lambda \lambda \mathrm{ov}$, porque

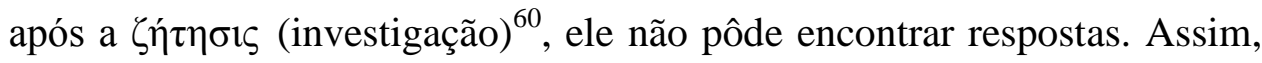

60 Consideraremos o escopo da investigação mais adiante, quando tratarmos do objeto da suspensão cética de juízo segundo Sexto Empírico. 


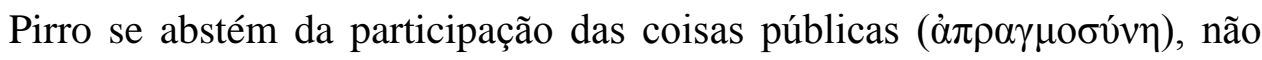
deixando que elas o afetem, tornando-se $\alpha \dot{\alpha} \alpha \theta \dot{s}$ (apático) diante delas, o que o faz tranquilo (i்vұíns).

Em suma, Pirro conseguiu extrair consequências éticas positivas das asserções negativas acerca dos limites humanos da cognição.

\subsection{Nos sucessores de Pirro}

A questão da sucessão de Pirro é problemática e, como já vimos, não é possível confiar de todo em D.L. IX 69 e 70 porque teríamos que fazer com que a

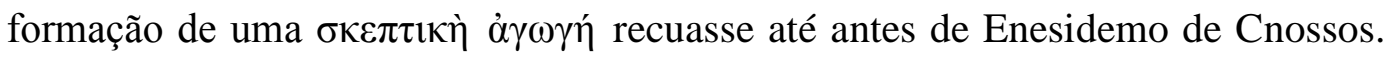
Contudo, podemos estar certos de que pelo menos Timão (circa 330-220 a.C.), Nausífanes (circa 360 a.C.), Euríloco (séc. III a.C.), Fílon de Atenas (séc. III a.C.), Numênio (séc. III a.C.), Hecateu e Ascânio de Abdera (ambos no séc. III a.C.) de fato foram convivas de Pirro $^{61}$ e influenciados por sua personalidade $\mathrm{e}$ filosofia/vida, embora possamos supor que não sem divergir, se levarmos a sério o relato do posicionamento tardio (séc. II d.C.) do médico Teodósio (D.L. IX, 70).

Timão de Fliunte provavelmente foi o mais célebre dos convivas de Pirro e, como assinala Brochard, o círculo do qual ele fazia parte, o do "primeiro pirronismo", talvez seja mais um grupo de "admiradores de Pirro, familiares ou imitadores dele" do que de fato discípulos formais dispostos em uma linhagem sucessória sob uma doutrina escolar ${ }^{62}$, como representaram D.L. e também Eusébio, no trecho que analisaremos em seguida (PE. 14. 18. 1-5), ao chamar Timão de " $\mu \alpha \theta \eta \tau \eta ́ \varsigma "$ ". Na verdade, houve por parte dos filósofos Helenísticos, bem como pelos historiadores e biógrafos do período, a necessidade de erigir sucessões entre filósofos, fazendo-as recuar a antecessores que serviriam como “autoridades" por detrás da fundação das filosofias, engrandecendo as genealogias das escolas, isso pode ser identificado nas primeiras fases do estoicismo e do epicurismo $^{63}$, e também no cinismo e no pirronismo.

\footnotetext{
${ }^{61}$ É possível que o nome Ascânio seja uma corruptela de Hecateu de Abdera. Ver: 'DECLEVA CAIZZI, F. (org.). Pirrone testimonianze. Nápoles: Bibliopolis, 1981’.

62 'BROCHARD, Victor. Os Céticos Gregos. São Paulo: Editora Odysseus, 2010', pág. 90.

${ }^{63}$ Com, respectivamente, as seguintes sucessões "semifantasiosas":

a) estoicismo:
} 
Os casos do cinismo e do pirronismo são semelhantes: ambos são mais

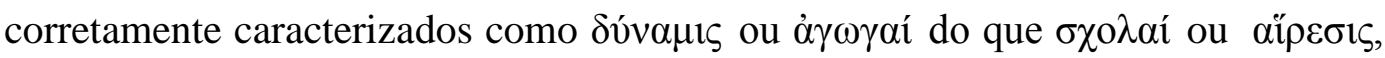
e antes de serem entendidos como escolas, como quiseram D.L. e PE, devem ser vistos como modos de vida cuja viabilidade prática de suscitar o alcance da

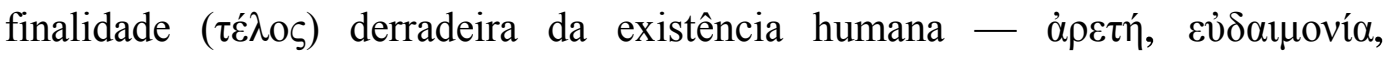

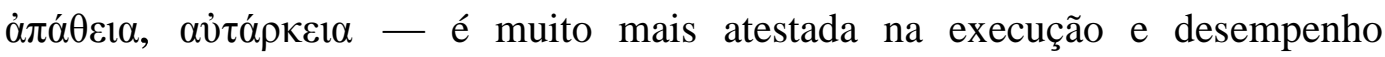
performático de um estilo de vida do que pela coesão teórica. Contudo, voltando a Timão, se não é um discípulo, como $P E$. quer que pensemos, foi o mais próximo entre os convivas de Pirro, viveu cerca de noventa anos, tendo abandonado sua profissão de dançarino para dedicar-se à filosofia por volta dos vinte e cinco, tornando-se primeiramente discípulo de Estilpo de Megara e depois, mudando-se para Élida, companheiro de Pirro que, com sua filosofia/vida, inspirou-o em seus escritos polêmicos e satíricos ( $\Sigma$ í $\lambda \lambda \mathrm{o})$, em três livros.

Além da proximidade com Pirro, Timão é considerado o maior porta-voz e divulgador da filosofia/vida de Pirro (ver, por exemplo, Adv. Gram. 53: "ó

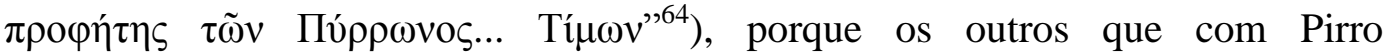
conviveram - Fílon de Atenas, Nausífanes, Euríloco, Hecateu e/ou Ascânio de Abdera e Numênio - parecem ter absorvido exclusivamente o caráter moral da filosofia/vida de Pirro, ou melhor, sendo mais preciso, absorveram exclusivamente a vida, ao passo que Timão absorveu também a filosofia. Por

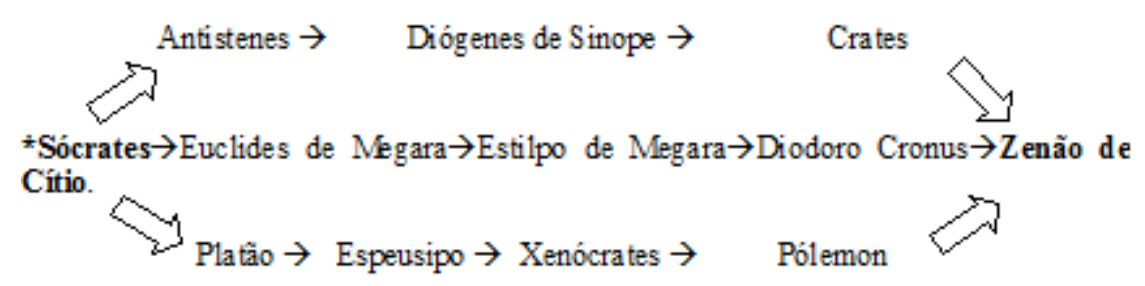

b) epicurismo:

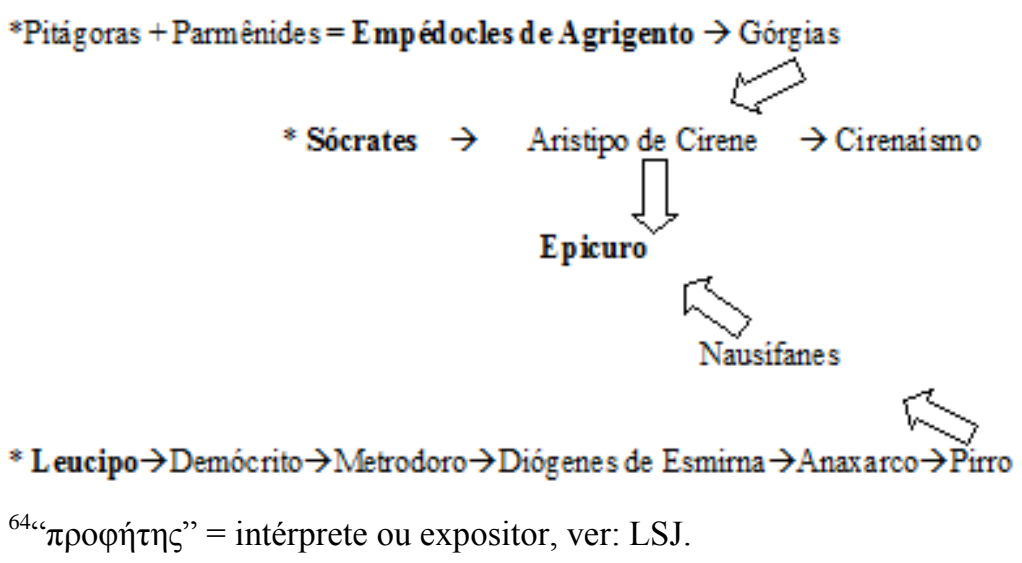


outro lado, serão escusados se lembrarmos de que era justamente na prática que Pirro se concentrava. Desse modo, antes de nos atermos aos fragmentos de Timão, devemos passar em revista os outros convivas de Pirro.

Começando com Fílon de Atenas (que não é o acadêmico que disputou com Enesidemo), não se ocupava "de glória ou querelas", assim como Pirro, falava sozinho para exercitar o discurso, mas fugia dos homens e preferia estar só

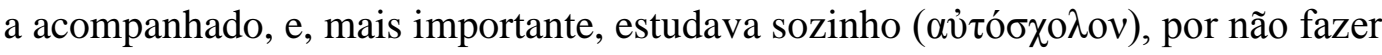

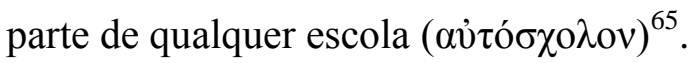

Nausífanes era mais propriamente um atomista do que um "pirrônico", dizia "que se deveria seguir a disposição ( $\delta$ iá $\theta \varepsilon \sigma ı)$ ) de Pirro", ou seja, tãosomente sua conduta prática, porque seguia sua própria razão ( $\lambda$ ó $\gamma \varsigma \varsigma$ ), fazendo uma distinção entre seu modo de pensar, influenciado pelo atomismo, e seu modo de se comportar, influenciado por Pirro ${ }^{66}$, o que ilustra o caráter quase que exclusivamente performático do "pirronismo", e o caráter mais teórico da física atomista, além da inexistência de uma disciplina escolar que definiria o pirronismo.

Euríloco era pouco dado a disputas intelectuais e debates sofísticos, preferia atravessar um rio a nado a exaurir-se com contendas, e era "belicosíssimo com relação aos sofistas" ${ }^{\prime 67}$. Hecateu de Abdera viveu entre a corte Lágida e escreveu tratados sobre os egípcios, sobre os judeus e Abraão ${ }^{68}$, pensava que a filosofia era algo prático, e não teórico ${ }^{69}$. Se Ascânio é outro, e não uma corruptela de Hecateu, nada de conclusivo se sabe sobre ele. Igualmente obscuro é Numênio, que não deve ser confundido com o neoplatônico homônimo de Apaméia (séc. II d.C.).

Assim, dentre os convivas de Pirro, é com Timão que começa a formação do que poderíamos chamar de "primeiro pirronismo" "70, com suas peculiares idiossincrasias e 'ganhos' conceituais:

\footnotetext{
${ }^{65}$ Ver D.L. IX, 69.

${ }^{66}$ Ver D.L. IX, 64.

${ }^{67}$ Ver D.L. IX, 69.

${ }^{68}$ Isi. et Osi., 9; Antiq. Jud., I, vii, 2.

${ }^{69}$ Ver: Contr. Apion., 1,22.

70 "Early Pyrrhonism", nas palavras de Anthony Long e David Sedley, ver: 'LONG, A.A.; SEDLEY, D.N. The Hellenistic Philosophers: translation of the principal sources, with philosophical commentary, Vols. 1 e 2. Cambridge: Cambridge University Press, 1987'.
} 
É completamente necessário investigar nossa própria capacidade de conhecimento

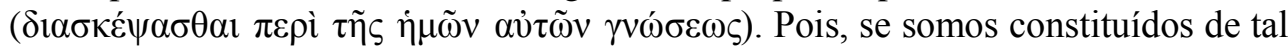
forma que ninguém sabe nada ( $\mu \eta \delta \grave{\varepsilon} v \ldots$... $\gamma v \omega \rho i ́ \zeta \varepsilon ı v)$, não há necessidade de

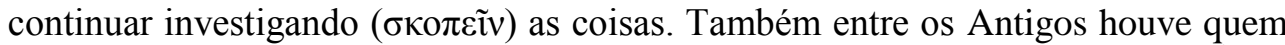
fizesse esse pronunciamento, e Aristóteles argumentou contra eles. Pirro de Élida foi também um poderoso defensor de tal posição. Ele próprio nada deixou por

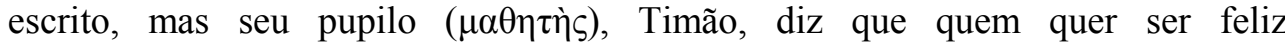

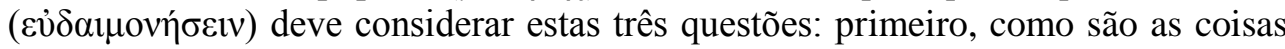

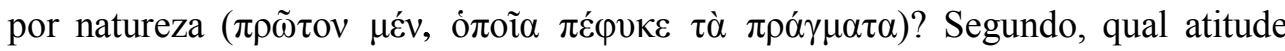

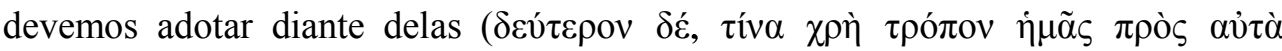
$\delta 1 \alpha \kappa \varepsilon i ٓ \sigma \theta \alpha)$ ? Finalmente, qual será o resultado para aqueles que têm essa atitude

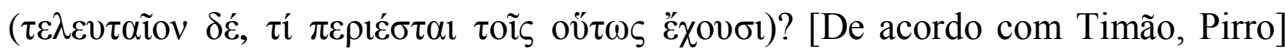
declarou que as coisas são igualmente indiferentes ( $\alpha \delta$ tó $\varphi \rho \rho \alpha)$, instáveis $(\dot{\alpha} \sigma \tau \alpha \dot{\alpha} \theta \mu \eta \tau \dot{\alpha})$ e indetermináveis ( $\dot{\alpha} v \varepsilon \pi i ́ \kappa \rho \imath \tau \alpha)$. Por isso, nem nossas sensações e

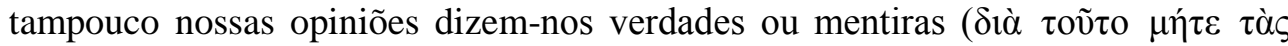

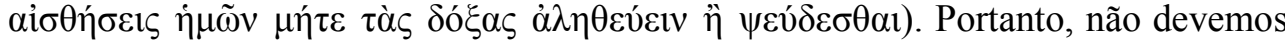
confiar nelas nem um pouco, mas não devemos opinar, inclinarmo-nos, abalarmo-

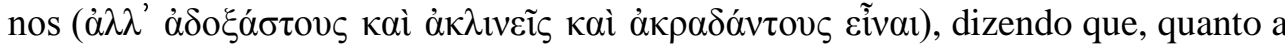
cada coisa, que não é mais do que não é, ou que tanto é quanto não é, ou que nem é

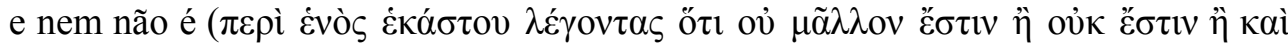

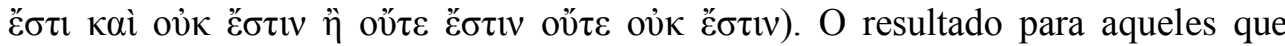
realmente adotam essa atitude, diz Timão, primeiro será a não asserção ( $\dot{\alpha} \varphi \alpha \sigma i ́ \alpha v)$,

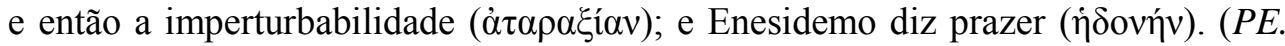
14. 18. 1-5).

O trecho acima é a transcrição de Eusébio de um fragmento de Aristócles (filósofo peripatético do séc. I d.C.) que, por sua vez, inicialmente faz uma introdução geral sobre os filósofos que asseriram a necessidade de se investigar

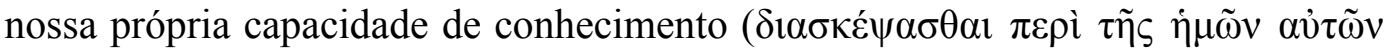

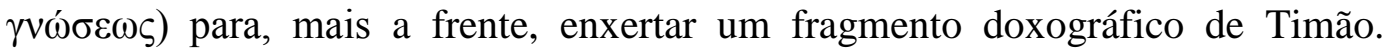
Enfatizamos aqui para o verbo " $\delta 1 \alpha \sigma \kappa \varepsilon \dot{\pi} \tau \tau$ $\mu \alpha \imath$ " (conjugado no aoristo infinitivo médio-passivo $=$ " $\delta 1 \alpha \sigma \kappa \varepsilon ́ \psi \alpha \sigma \theta \alpha \imath ")$, que significa "investigar a fundo", composto pela preposição " $\delta i \alpha ́$ " (= através de, no meio de, em, à distância, depois, por cima, sobre, ao largo, completamente) somada ao verbo " $\sigma \kappa \varepsilon ́ \pi \tau o \mu \alpha \imath "$ (= uma forma

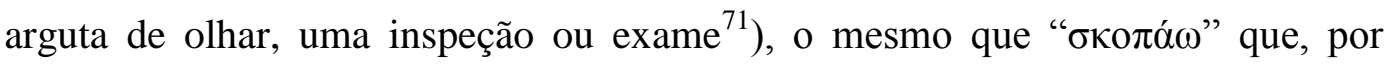

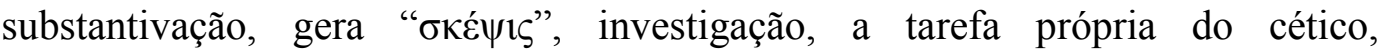

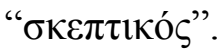

Segundo Aristócles, apud. Eusébio, devemos investigar nossa própria capacidade de conhecer, assim, o âmbito da investigação é epistemológico, o objetivo é saber se de fato o homem é constituído de tal forma a não saber nada, por onde podemos inferir que o alvo do emprego do método investigativo é a

\footnotetext{
${ }^{71}$ Ver: 'SNELL, B. A cultura grega e as origens do pensamento europeu. São Paulo: Perspectiva, 2005'.
} 
verificação da verdade de uma asserção que só pode ter sido feita por aqueles que defenderam que não se pode saber nada, ou seja, algum filósofo "protocético" e dogmático negativo, provavelmente atomista. A confirmação dessa interpretação vem nas linhas seguintes, quando Aristócles diz que "Aristóteles argumentou contra eles", logo, “eles" são aqueles que Aristóteles pensava que haviam violado o princípio de não contradição, justamente os "protocéticos", como vimos.

Em seguida, há a menção a Pirro como "um poderoso defensor de tal posição". Mas, considerando que são descritas três posições - a dos que defendiam que "somos constituídos de tal forma que ninguém sabe nada", que são os "protocéticos", em uma asserção clássica dogmática negativa; a posição de Aristóteles, que debateu com os anteriores; e a posição dos que defendiam que é "necessário investigar nossa própria capacidade de conhecimento", que são os céticos, como deduzimos pela escolha de Aristócles do aoristo infinitivo médio-

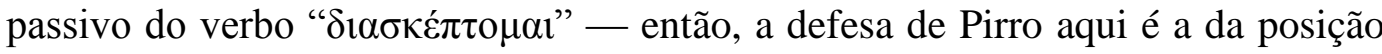
dos que investigam ${ }^{72}$, por isso, pela primazia da investigação, que ele "nada

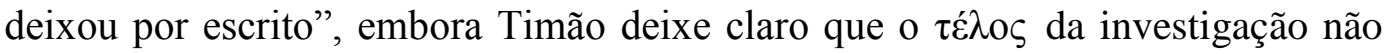
seja ela em si, mas a obtenção da felicidade ( $(v j \delta \alpha \mu$ ovía), para a qual se deve considerar três coisas: o estatuto ontológico das coisas, em sua natureza ( $\pi \rho \tilde{\omega} \tau o v$

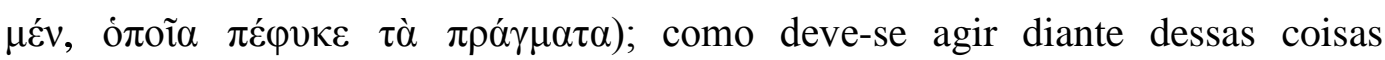

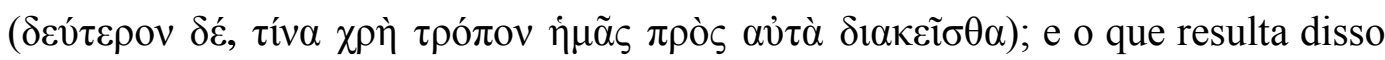

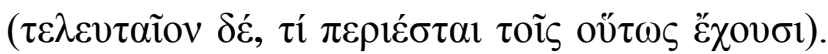

Nas linhas imediatamente posteriores ao relato de Timão das três questões supracitadas, há o relato das respostas para essas questões, de modo que podemos esquematizar o argumento como a seguir:

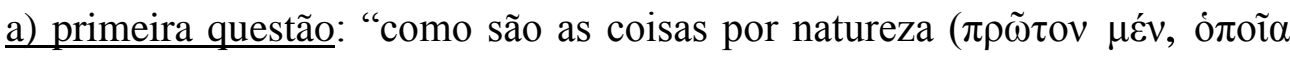
$\pi \varepsilon ́(v \kappa \varepsilon \tau \grave{\alpha} \pi \rho \alpha ́ \gamma \mu \alpha \tau \alpha) ? "$

Resposta: "as coisas são igualmente indiferentes ( $\dot{\alpha} \delta \dot{\alpha} \varphi \rho \rho \alpha)$, instáveis

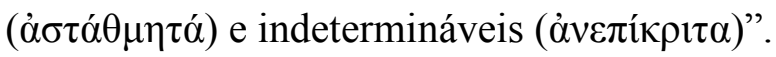

\footnotetext{
72 Apesar de Pirro ter feito, por vezes, asserções dogmáticas negativas, não há contradição textual aqui, basta recordarmo-nos que aqui é Timão quem nos fornece o relato transmitido por Aristócles, portanto, devemos considerar que já houvesse, por parte de Timão, a preocupação em dar mais coesão à postura investigativa (cética) que ele próprio parece ter adotado.
} 
Conclusão provisória: "Por isso, nem nossas sensações e tampouco nossas

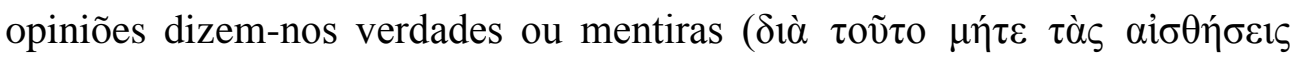

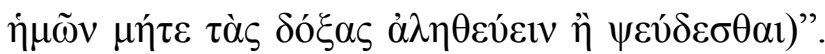

b) Segunda questão: "qual atitude devemos adotar diante delas [as coisas

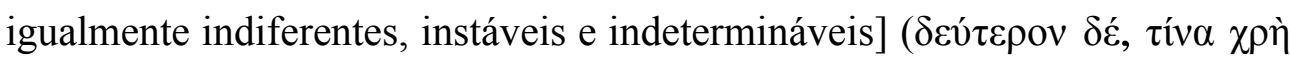

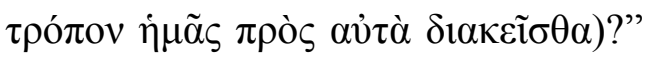

Resposta: "não devemos confiar nelas nem um pouco, mas não devemos

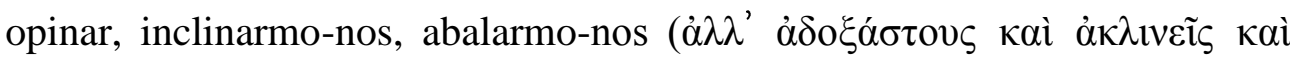

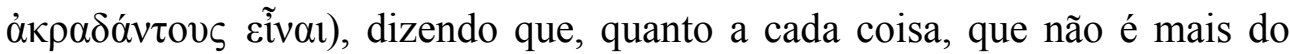
que não é, ou que tanto é quanto não é, ou que nem é e nem não é ( $\pi \varepsilon \rho \grave{~} \varepsilon$ vò $\zeta$

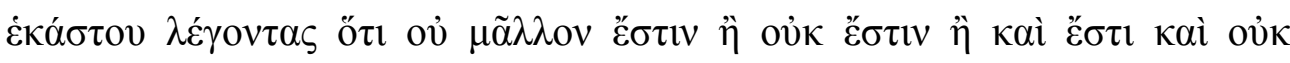

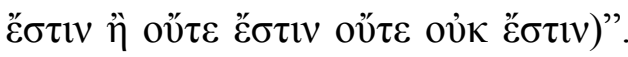

c) Terceira questão: “qual será o resultado para aqueles que têm essa atitude [não opinativa, sem inclinações e inabalável, e que não assere que algo é (mais do que não é), ou que tanto é quanto não é, ou que nem é e nem não é]

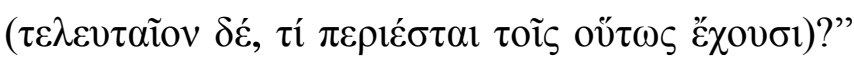

Resposta: "o resultado para aqueles que realmente adotam essa atitude, diz Timão, primeiro será a não asserção ( $\alpha \varphi \alpha \sigma i ́ \alpha v)$, e então a imperturbabilidade

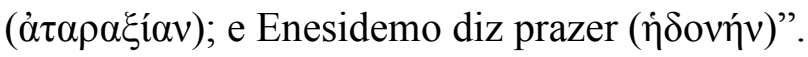

A todo momento, Aristócles, falando pela boca de Eusébio, refere-se a Timão como o porta-voz de Pirro, assim, é Timão quem propõe as três questões, e também as três respostas. Contudo, por ter sido conviva e comensal de Pirro, mesmo que a formulação descrita no trecho não seja do próprio Pirro, a formulação de Timão resulta do contato que com ele teve, portanto, não se pode saber ao certo em que medida Timão está adaptando as formulações de Pirro. Apesar disso, se estamos certos em nossa argumentação sobre a "vida de Pirro", devemos concordar que para ele a finalidade do método investigativo de fato é moral.

Da mesma forma, se recordarmos que Pirro era um dogmático negativo, de inspiração atomista em teoria do conhecimento, podemos concluir que ele poderia pensar, sim, que as coisas eram por natureza indiferentes, instáveis e indeterminadas, uma asserção dogmática (uma vez que afirma como os objetos 
são por natureza) que não precisa ser espúria, além disso, a necessidade da investigação, que é a posição que Pirro defende, emerge justamente da percepção da dubiedade das coisas, que para ele é inerente à própria constituição dessas coisas (como também era para Heráclito, Protágoras e os atomistas). E é precisamente pela indiferença, instabilidade e indeterminação das coisas em si mesmas que as sensações e as opiniões são incapazes de dizer verdades ou mentiras sobre elas, porque não tocam os objetos, naturalmente inescrutáveis.

E então, considerando tal inescrutabilidade, não podemos confiar nas coisas, devemos nos conservar sem opiniões, sem inclinações ou abalos, evitando nos pronunciar quanto à realidade das coisas. Como resultado, alcança-se um estilo de vida não assertórico, imperturbável e prazeroso.

Bem, tendo dito isso, resta-nos considerar alguns problemas que emergem:

1- claramente, há uma contradição entre: a) asserir que as coisas são por natureza inescrutáveis; e b) prescrever um modo de vida não assertórico.

2- Como já vimos, temos motivos para rejeitar a atribuição da palavra

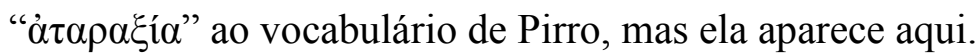

Para os dois problemas acima, temos as seguintes réplicas:

R1- de fato, há uma contradição entre (a) e (b), e parece ainda que ela perdurou, por um lado, até a academia em fase cética - que pretendeu resolvê-la recorrendo ao critério do 'provável', apelando para uma noção dogmática como solução moral e de conduta prática, diante da asserção igualmente dogmática da inescrutabilidade das coisas, e abrindo mão do ceticismo, como veremos depois - e, por outro lado, até Sexto Empírico, que optou pela caracterização do discurso do cético como não assertórico, reduzindo seu compromisso com a verdade, ou com a natureza dos objetos, e ligando-o à percepção das coisas como elas (a)parecem ser, como veremos também depois;

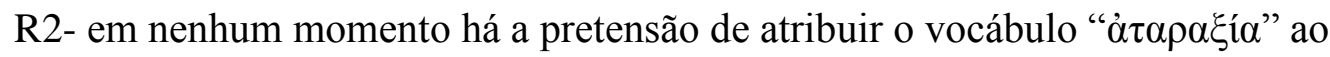
próprio Pirro aqui, pelo contrário, Aristócles deixa claro que isso é o que "diz Timão", e coloca ao lado do que "Enesidemo diz" (†்ovท́v), corroborando que ambas são palavras surgidas na recepção da filosofia/vida de Pirro, e não 
arcabouço conceitual dele próprio, desse modo, podemos atribuir o acréscimo

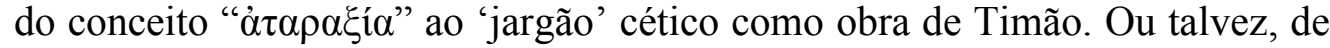
um modo mais abrangente, como obra do círculo dos convivas de Pirro, incluindo Nausífanes, o que poderia justificar o uso epicurista do mesmo conceito, transmitido pelo próprio Nausífanes, mestre de Epicuro.

Ademais, se devem a Timão outras importantes adaptações, como a

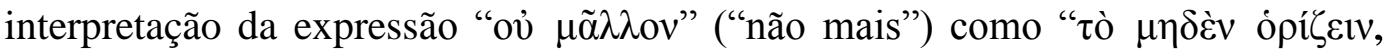
$\dot{\alpha} \lambda \lambda$ ' $\alpha \operatorname{\rho o\sigma } \theta \varepsilon \tau \varepsilon i ̃ v "$ ("nada definir, ou seja, suspender o juízo") ${ }^{73}$. É importante notar o uso, por Timão, de um vocábulo que significa "suspensão de juízo", ou

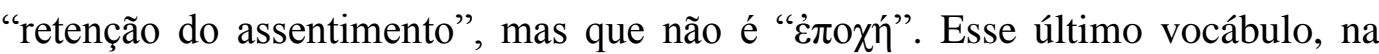
verdade, aparece no mesmo passo D.L. IX 76, mas algumas linhas abaixo, vinculadas a metáforas médicas. Se considerarmos que a infiltração do pirronismo nas discussões médicas só ocorre por volta do séc. I d.C., após Agripa ter escrito

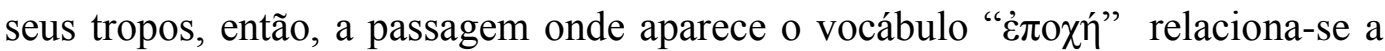
um ceticismo pirrônico que já tem ganhos conceituais cronologicamente

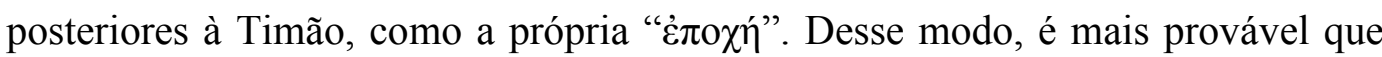

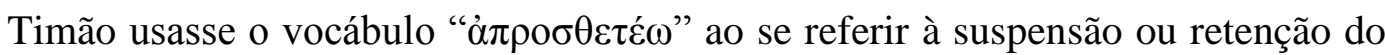
assentimento.

Também se deve a Timão a instauração da figura de um cético que ao

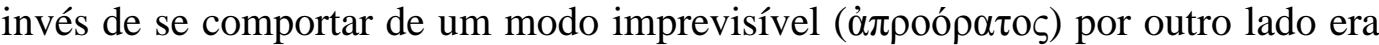
um cidadão comum, que não afrontava os costumes e era coagido pelos fenômenos, deixando-se conduzir pelas aparências:

Os dogmáticos dizem, ainda, que [os céticos] destroem a vida, ao rejeitarem todas

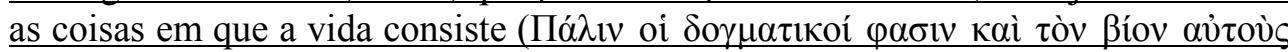

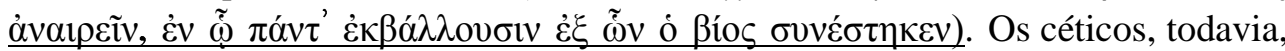
dizem que os dogmáticos mentem. "Pois não rejeitamos o que vemos, ignoramos apenas como vemos. E tomamos o fenômeno, sem defender que a coisa seja tal. E

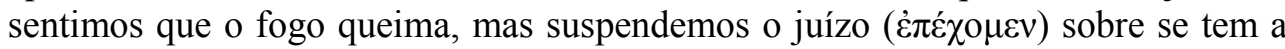
capacidade de queimar por natureza.

Vemos que alguém se move e que outro morre. Mas não sabemos como isso acontece. "Então", dizemos, "apenas contrapomos aos fenômenos as indicações

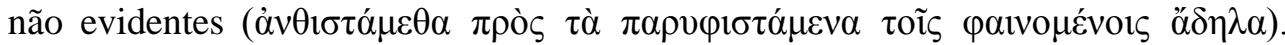
Pois, quando dizemos ter uma imagem saliências, tornamos manifesto o fenômeno. Quando, porém, dizemos que ela não tem saliências, jamais dizemos o que aparece

${ }^{73}$ Ver: D.L. IX 76. 
diferente do fenômeno". Com efeito, Timão, no Píton, afirmava não ter afrontado o

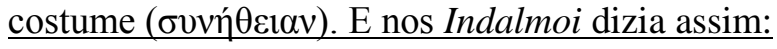

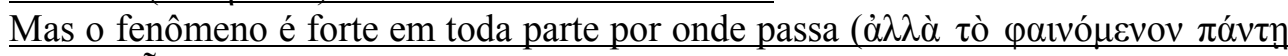

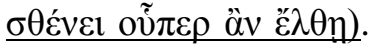

E, em Sobre as sensações, observa, "não coloco que o mel é doce, mas concordo que assim me parece". (D.L. IX, 104-105. Grifos nossos).

$\mathrm{Na}$ passagem acima se faz claro o surgimento de uma crítica ao ceticismo que afirma que ele destrói a própria vida, uma vez que rejeita tudo em que ela consiste. Essa alegação não é mais nem, por um lado, como aquela de Aristóteles - para quem a rejeição, por meio do discurso, do princípio de não contradição é auto refutativa - e nem, por outro lado, como aquela que diz que o comportamento do cético é imprevisível. Algumas linhas abaixo da crítica há uma defesa que define o escopo da suspensão de juízo:

\footnotetext{
"Pois não rejeitamos o que vemos, ignoramos apenas como vemos. E tomamos o fenômeno, sem defender que a coisa seja tal. E sentimos que o fogo queima, mas

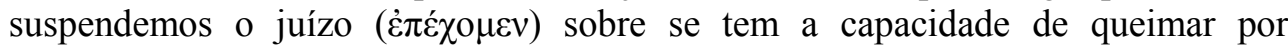
natureza."
}

Mas aqui há a alegação de que não se sabe como as coisas (por exemplo, o fogo) são por natureza, contudo, quando analisamos $P E$. 14. 18. 1-5, vimos que Timão dizia que as coisas são, por natureza, inescrutáveis. Ademais, vimos também que

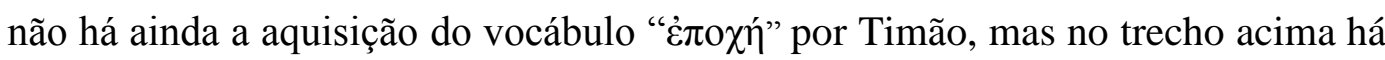

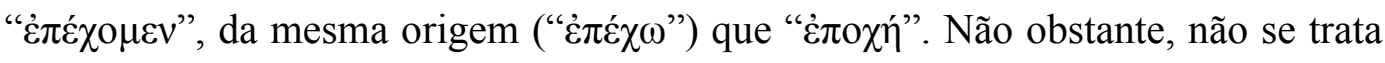
de uma contradição: mais uma vez, D.L. sobrepõe diferentes relatos e ganhos conceituais do ceticismo de forma anacrônica, e não diacrônica ou cronológica, de modo que o trecho acima selecionado, que narra uma crítica anticética posterior a Timão, sirva em D.L. de introdução para a citação de três fragmentos do próprio

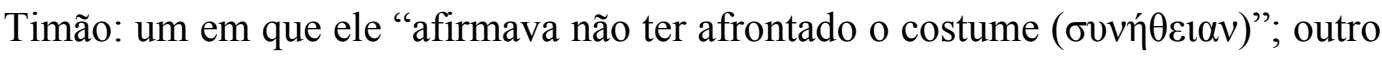
em que ele diz que "o fenômeno é forte em toda parte por onde passa ( $\dot{\alpha} \lambda \lambda \grave{\alpha}$ tò

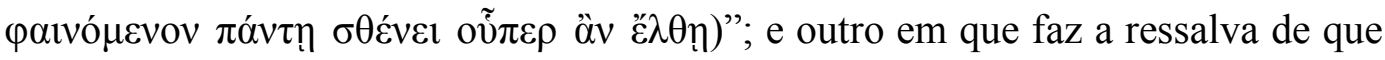
"não coloc[a] que o mel é doce, mas concord[a] que assim me parece".

Agora, se estamos certos de que as críticas anticéticas que aparecem em D.L. IX 104-105, bem como a defesa cética imediatamente posterior que define o

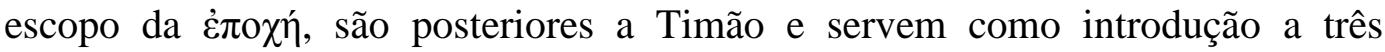
fragmentos dele enxertados no texto, então devemos considerar a réplica e a tréplica em seu devido momento, quando tratarmos do debate da academia $\mathrm{X}$ 
Stoá. Por hora, recapitularemos quais são os desenvolvimentos conceituais da

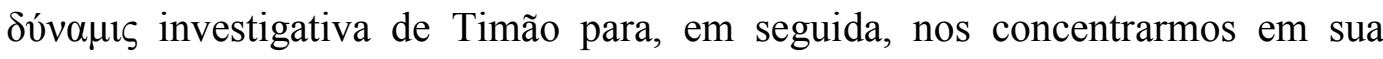
belicosidade:

1- Timão, seguindo o atomismo de Pirro, era um dogmático negativo em teoria do conhecimento.

2- Contudo, pensava que, mesmo assim, dever-se-ia investigar como as coisas são por natureza. Mas Timão introduz os correlatos do vocábulo

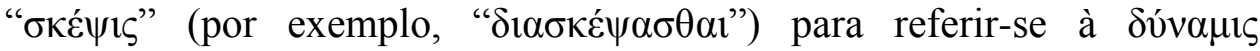

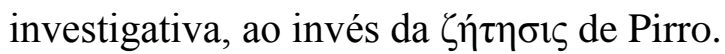

3- Como resultado da investigação não surgem a aporia ou a diafonia sextianas, mas a certeza dogmática de que as coisas são naturalmente

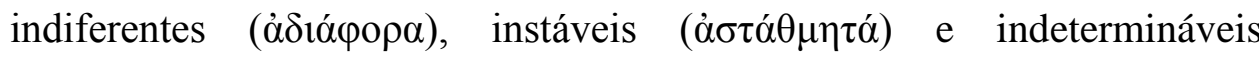

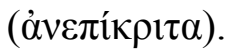

4- Diante disso, devemos abrir mão da pretensão à verdade, suspendendo o

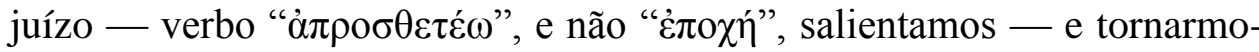
nos sem opiniões, sem inclinações e não deixarmo-nos abalar ( $\dot{\alpha} \delta$ o $\xi \alpha ́ \sigma \tau o v \varsigma$

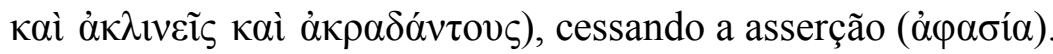

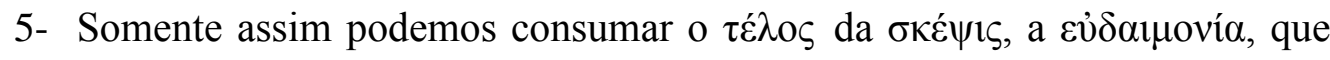
ganha sua definição negativa clássica: $\alpha \dot{\tau} \alpha \rho \alpha \xi i ́ \alpha$.

6- Finalmente, há a transformação da fórmula "ov̉ $\mu \tilde{\alpha} \lambda \lambda o v$ ” em uma

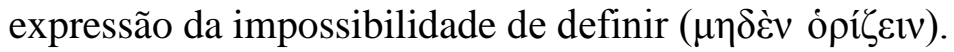

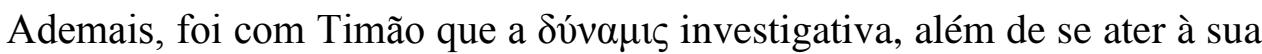

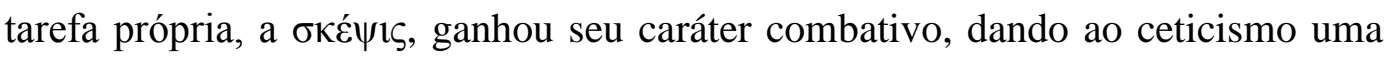
das suas maiores marcas distintivas: a agonística. De fato, o objetivo de Timão era, com inspiração literária cínica ${ }^{74}$ (iambos e meliambos satíricos que, por sua vez, têm sua invenção atribuída à Xenófanes de Cólofon, em suas paródias à Homero e Hesíodo $)^{75}$, e com inspiração filosófica igualmente cínica, demonstrar a

\footnotetext{
${ }^{74}$ Ver: 'LONG, A. A. A tradição socrática: Diógenes, Crates e a ética Helenística. In: GOULETCAZÉ, M-O; BRANHAM, R. B. (orgs.). Os cínicos: o movimento cínico na Antiguidade e seu legado. São Paulo: Loyola, 2007'.

${ }^{75}$ Vale notar ainda que Timão dedica seus " $\Sigma$ í $\lambda \lambda$ ol" à Xenófanes, também ele um autor de “ $\Sigma \hat{\imath} \lambda \lambda$ ol”, ver: D.L. IX 18 (Fr DK 21 A ).
} 


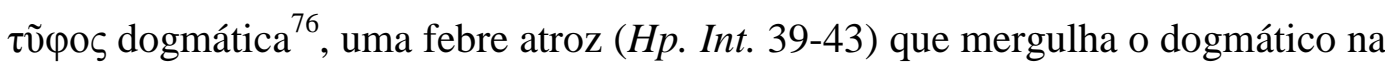

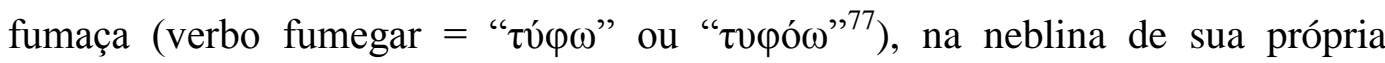
vaidade (Onos. 42.24; Plb. 3.22.4), que é a causa derradeira das ilusões (De Piet. 21) e do comportamento afetado daqueles que pensam que são sábios (Vit. Par., Vida de Péricles, 5). O único modo de evitar essa $\tau \tilde{u} \varphi \varsigma_{\varsigma}$ é vivendo com

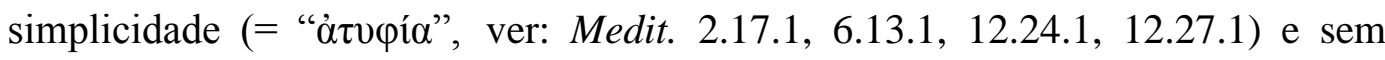

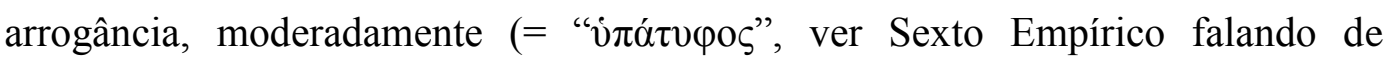
Xenófanes em: P.H. I, 224). Desse modo, Timão não hesita em atacar os

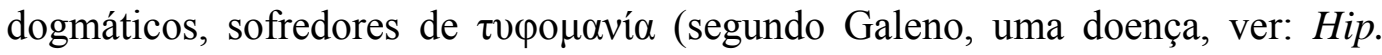

Pror. Com. 16, 497, 11):

Há três livros dos Silloi, nos quais Timão, adotando a postura de um cético, insulta a todos e satiriza a todos os dogmáticos por meio da paródia. O primeiro livro tem ele por narrador, enquanto que o segundo e o terceiro são diálogos. Ele aparece interrogando Xenófanes de Cólofon sobre cada filósofo, e Xenófanes responde-lhe. No segundo livro ele lida com os filósofos mais Antigos, e no terceiro com os filósofos recentes, razão pela qual esse último livro recebeu de alguns o nome de Epílogo. O primeiro livro cobre os mesmos assuntos, exceto que o poema é em forma de monólogo. Ele começa assim: "Dize-me agora, intrometidos

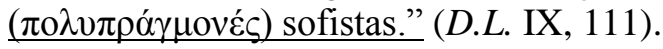

$\mathrm{Na}$ passagem acima, devemos notar primeiramente a forma dialógica de dois dos três livros dos Silloi, em que Xenófanes é quem conversa com Timão, estando, portanto, imune à polêmica que se abaterá sobre os outros filósofos, tanto Antigos como recentes ${ }^{78}$, tratados genericamente como sofistas e acusados de $\pi \mathrm{o} \lambda v \pi \rho \alpha \gamma \mu о \sigma v ́ v \eta$, o vício diametralmente oposto à virtude pirrônica da

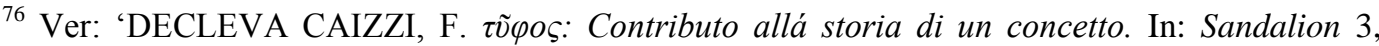
1980', págs. 53-66. E: 'BRANCACCI, A. La filosofia di Pirrone e le sue relazioni com il cinismo. In: GIANNANTONI, G. (org.). Lo scetticismo ântico. Roma, 1981'.

${ }^{77}$ Ver Crates, parodiando a descrição homérica de Creta: "Há uma cidade Pêra no meio da neblina

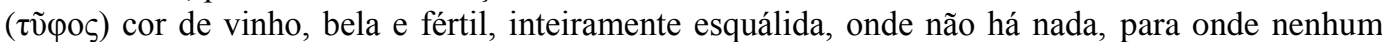
tolo navega, nenhum parasita ou devasso que se delicie com o traseiro de uma prostituta; mas que tem tomilho e alho, figos e pães, que não são causa para seus habitantes guerrearem entre si, nem pegam eles em armas por lucro ou por fama." (Socr. Rel. v.2, V H 70).

${ }^{78}$ Não só Xenófanes estava imune aos virulentos ataques de Timão, todo o círculo eleata era admirado por ele: "E a força do magnânimo Parmênides não foi a multiplicidade das opiniões; expulsou a imaginação enganosa e introduziu em seu lugar os pensamentos" (D.L. IX, 23); "Zenão [de Eléia], com sua grande força, dificilmente resistível, capaz de defender uma tese e seu contrário, severo crítico de todos, e Melisso, sobressaindo entre os numerosos fantasmas, cedem somente a poucos" (D.L. IX, 25). E principalmente os atomistas: "É assim o sábio Demócrito, pastor de palavras, conversador talentoso, que reconheço entre os primeiros" (D.L. IX, 40). Havia também uma admiração por Protágoras: "O principal de todos os sofistas, dos primeiros e dos últimos, não faltando clareza de discurso ou visão ou versatilidade, Protágoras. Queriam fazer uma fogueira de seus escritos, porque escreveu que não conhecia e não podia observar como os deuses são e se algum deles existe, salvaguardando completamente sua honestidade" (Adv. Phy. I, 57).
} 
$\dot{\pi} \rho \alpha \gamma \mu$ $\sigma 0 ́ v \eta$, como vimos em nosso comentário sobre a "vida de Pirro". Na verdade, os principais alvos de Timão eram Epicuro — "Último dos físicos, o mais desavergonhado, vindo de Samos, escolarca, o mais ignorante dos seres vivos" (D.L. X, 2) 一, Sócrates e a tradição socrática, incluindo os acadêmicos, os estoicos e excetuando os cínicos:

A partir deles [Sócrates] o cortador de pedras, tagarela de leis, se virou... (Adv. Log. I, 8).

Por isso Timão culpa Platão por enfeitar Sócrates dessa maneira com múltiplas disciplinas: pois Platão, diz ele, "sofria por não ter permanecido tão somente um professor de ética". (Adv. Log. I, 10).

Não me importo com esses tagarelas, nem com outros [socráticos] quaisquer, nem com Fédon, seja ele quem for, nem com o briguento Euclides [de Megara], que transmitiu aos megáricos o amor frenético pela controvérsia. (D.L. II, 10).

Nem [ligo para (?)] de Aristóteles, a penosa futilidade... (D.L. V, 11).

Vi [o Estoico Zenão de Cítio,] uma gananciosa velha pescadora fenícia, cheia de orgulho vil, desejosa de tudo. Os fios de seu tecido sutil jamais se desfizeram, e sua inteligência era menos do que um instrumento de cordas. (D.L. VII, 15).

Ora, finalizamos esse estudo dos "sucessores de Pirro" com dois problemas: a sucessão de Timão e o começo do debate com os estoicos, dois assuntos interligados que analisaremos na próxima seção. 


\section{Apraxía, autorefutabilidade e fórmulas céticas no debate da academia X Stoá}

\subsection{Timão, Arcesilao, Carnéades e Clitômaco}

Aparentemente, teria havido um contato estreito entre Timão e o acadêmico Arcesilao, pelo menos no âmbito crítico, como podemos ver pelo seguinte fragmento de Timão, citado por D.L. :

Assim falando ele se misturava à multidão. As pessoas contemplavam-no admiradas, como tentilhões em torno de uma coruja, apontando-o como estulto, por ser um adulador da turba. Porque, insignificante como és, inchas como um tolo? (D.L. IV, 42).

$\mathrm{Ou}$, da mesma forma, pela anedota:

Arcesilao perguntou [a Timão] em certa ocasião porque viera de Tebas para Atenas, e sua resposta foi: "Para rir, vendo-vos em exibição ao ar livre." (D.L. IX, 115).

Por outro lado, "embora atacando Arcesilao nos Sílloi, Timão lhe faz elogios na obra intitulada Banquete Fúnebre de Arcesilao" (D.L. IX, 115). Contudo, não é certo se tal obra de fato existiu ou se é uma invenção pela qual se pretendia evidenciar, ou talvez forjar, a continuidade da filosofia/vida de Pirro, passando por Timão e chegando a Arcesilao. Mesmo assim, apesar das aporias, é possível que Timão tenha atacado Arcesilao durante toda a vida e, diante da morte de seu adversário, tenha voltado atrás e o elogiado, principalmente se levarmos em conta o fragmento em que Timão assume que Arcesilao realmente agia como um pirrônico: "Tendo o chumbo de Menêdemos no peito ele correrá para Pirro, todo carne, ou para Diodoro" (D.L. IV, 33).

Ademais, além de Timão, Aríston de Quíos, o filósofo meio estoico e meio cínico apelidado de sereia, pronunciou-se acerca da postura pirrônica da quimera Arcesilao: "Pela frente Platão, por trás Pirro e no meio Diodoro" (D.L. IV, 33). E, 
mesmo séculos depois, o estoico Sêneca fora levado a pensar que os acadêmicos, a começar por Arcesilao, foram legítimos sucessores de Pirro:

Tantas escolas passam adiante sem sucessor. Os acadêmicos, tanto os Antigos quanto os mais recentes, não deixaram representante. Quem está lá para carregar os ensinamentos de Pirro? (Quaest. Natu. 7.32.2).

E também Numênio (in: PE. 14.6.4-6) e Sexto Empírico ${ }^{79}$ pensavam que:

Arcesilao (...) certamente parece-me como tendo compartilhado o discurso de Pirro

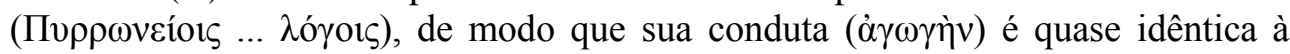
nossa. Pois não the vemos fazendo qualquer asserção sobre a realidade ou a irrealidade de algo, tampouco ele prefere qualquer coisa à outra quanto à

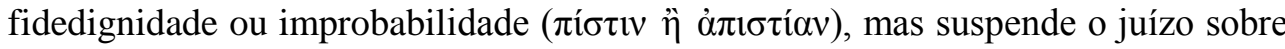

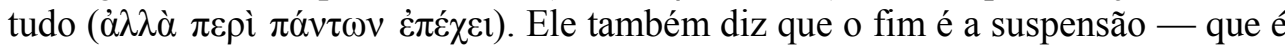

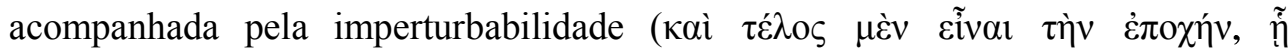

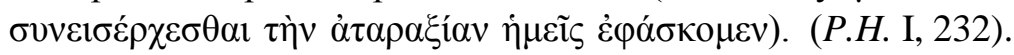

Contudo, Sexto, tendo em vista todos os ganhos conceituais que o ceticismo já havia adquirido em sua época (séc. II ou III d.C.), não considerava Arcesilao inteiramente pirrônico, uma vez que atribuía valor à suspensão de juízo (boa) e ao assentimento (mau), usava a dialética como um método para suscitar aporias e verificar a adesão de outrem aos dogmas de Platão (ver P.H. I, 234).

Mas, antes de prosseguirmos em nossa investigação, façamos um breve relato biográfico do pouco que se pode saber sobre Arcesilao (circa 318-242 a.C.). Primeiramente, o seu percurso de estudos:

Antes de transferir-se para Atenas, Arcesilao ouviu as lições do matemático Autôlicos, seu concidadão, com quem fez uma viagem a Sárdis. Em seguida, estudou com o músico Xantos, ateniense, e depois foi aluno de Teofrasto. Mais tarde passou para a academia e juntou-se a Crântor. (D.L. IV, 29).

Arcesilao era um $\pi$ o $\lambda v \mu \alpha \theta \eta ́ \varsigma \varsigma$ que, de acordo com uma versão bastante convencional de $\pi \alpha ı \delta \varepsilon i ́ \alpha$ (composta por treinamento em música, matemática e recitação de poemas tradicionais), buscava erudição. Finalmente, treinou-se também em refutações sofísticas e argumentação, como percebemos nas alegações de que havia sido aluno de Diodoro Cronos - célebre dialético de linhagem filosófica meio socrática meio eleática, discípulo da escola de Megara, "teria sido

\footnotetext{
${ }^{79}$ Para Sexto é equivocada a atribuição de uma postura pirrônica aos acadêmicos, com a exceção de Arcesilao.
} 
o primeiro a descobrir o argumento do velado e o argumento do cornudo" (D.L. II, 111) - e também nas citações abaixo:

(...) Teofrasto, magoado com sua partida, disse que um jovem bem-dotado e arguto havia deixado a escola [peripatética]. Com efeito, além de extremamente apto em argumentação e realmente amigo de ler e escrever, ele também se dedicava a compor poemas. (D.L. IV, 30).

Entre todos os poetas, Arcesilao apreciava mais Homero, de quem lia habitualmente algum trecho antes de dormir; mesmo de manhã cedo, quando queria ler Homero, dizia que desejava visitar seu amor. De Píndaro costumava afirmar que era uma fonte incomparável para transmitir a plenitude da elocução e para proporcionar uma provisão abundante de palavras e frases. (D.L. IV, 31).

De fato, para Arcesilao a leitura dos poetas e oradores consistia em uma forma

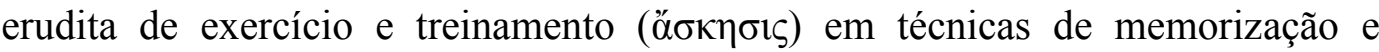
argumentação, aperfeiçoadas a tal ponto que a marca distintiva de seu modo de filosofar era justamente seu vigor argumentativo, por vezes extremamente sarcástico $^{80}$ (talvez por influência do também debochado Timão):

Arcesilao era extremamente inventivo quando se tratava de rebater com sucesso as objeções, ou de trazer o curso da discussão de volta ao ponto em debate, e adaptava-se a qualquer situação. Ninguém rivalizava com ele no poder de persuasão, e isso, mais do que qualquer outra coisa, trazia discípulos para a escola, embora temessem seu espírito ferino. (D.L. IV, 37).

Mas, também na academia, sob Crântor (circa 340-290 a.C.) — por sua vez, discípulo de Pólemon (acme 314 a.C.), que foi, como veremos, mestre do estoico Zenão de Cítio e discípulo de Xenócrates (circa 396-314 a.C.), por seu turno, discípulo de Espeusipo (circa 407-339 a.C.), sucessor direto de Platão na liderança de sua escola - Arcesilao pôde ter em si incutido o gosto pelo debate, uma vez que o próprio Platão havia dado seu "consentimento" às divergências ${ }^{81} \mathrm{e}$ afirmado que o aprendizado não pode ser coagido (Rep. 536e-f).

Assim, se lembrarmos de que Platão morrera em 347 a.C. (vinte e nove anos antes do nascimento de Arcesilao), então provavelmente não havia na época de Arcesilao sequer um filósofo da academia que tivesse conhecido diretamente

\footnotetext{
${ }^{80}$ Ver D.L. IV, 43: ‘... a alguém que lhe perguntou porque os discípulos de outras escolas corriam para a [escola] de Epicuro, mas da escola epicurista jamais um discípulo passou para as outras, Arcesilao replicou: "Porque os homens podem tornar-se eunucos, porém um eunuco jamais pode tornar-se um homem.'

${ }^{81}$ Ver a interpretação de Aristóteles sobre isso em Nic. Eth. 1.6, 1096a12-17; e as objeções que Platão levanta contra sua própria teoria das formas em todo o Parm.
} 
Platão. Além disso, não havia também método e currículo formalizados, de modo que quem quisesse compreender as filosofias de Platão e de Sócrates deveria ler os diálogos de Platão. Ora, aqueles que se aventuram na tentativa de compreender os diálogos, ou a posição e a doutrina de Platão neles, sabem que as filosofias de Platão e de seu personagem Sócrates se fazem através da dialética, e isso está indicado pela própria preferência da escrita em forma dialógica que "é a ilustração viva de um método que investiga e que, com frequência, se investiga." ${ }^{~} 2 \mathrm{E}$ Arcesilao aderiu justamente ao modo socrático de fazer filosofia conforme apresentado pelos diálogos de Platão: a dialética (desenvolvida ainda mais por Diodoro Cronos), dando-a uma interpretação dogmática negativa (possivelmente advinda da transmissão por Timão da filosofia de Pirro) — ao rejeitar a possibilidade de apreender a verdade, seja pela mente ou pelos sentidos - e cética - ao perceber a possibilidade dialética de, para cada argumento, defender um oposto:

[Arcesilao foi] o primeiro a adotar, através dos variados livros de Platão e dos diálogos de Sócrates, especialmente a ideia de que não há certeza que possa ser apreendida tanto pelos sentidos quanto pela mente (nihil esse certi quod aut sensibus aut animo percipi possit). Nessa completa rejeição da mente e dos sentidos como instrumentos do juízo, dele se diz que empregou um modo de falar excepcionalmente elegante, e também que foi o primeiro a estabelecer a prática (quem ferunt eximio quodam usum lepore dicendi aspernatum esse omne animi sensusque iudicium primumque instituisse) - embora fosse muito característica de Sócrates - de não revelar seus próprios pontos de vista, mas sempre argumentar contra qualquer ponto de vista que qualquer um asserisse. (De Or. 3.67).

Agora, se Arcesilao era realmente um exímio argumentador e debatedor, o

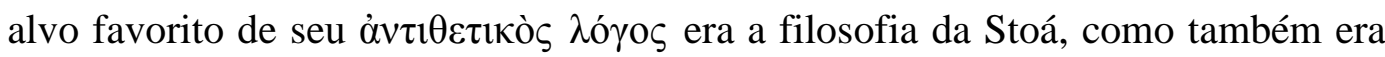
para Timão e para os acadêmicos Carnéades (circa 213-129 a.C.) e Clitômaco (acme 129 a.C.), seguindo o exemplo de Arcesilao. Dessa forma,

[Carnéades] estudou detidamente as obras dos estoicos, em particular de Crisipo, e combatendo-os com sucesso tornou-se tão famoso que costumava dizer: "Se não existisse Crisipo, tampouco eu seria quem sou". (D.L. IV, 62).

Clitômaco nasceu em Cartago. Seu nome verdadeiro era Asdrúbal, e ensinou filosofia em sua pátria em seu próprio idioma. Aos quarenta anos foi para Atenas e passou a ser discípulo de Carnéades, que lhe apreciava a diligência, e fê-lo aprender o grego e participou de sua instrução. Clitômaco mostrou-se tão esforçado que escreveu mais de quatrocentos livros. Sucedeu a Carnéades, cuja doutrina

82 'GOLDSCHMIDT, V. Os diálogos de Platão: estrutura e método dialético. São Paulo: Loyola, 2010.' 
explicou principalmente em seus escritos, e conhecia muito bem as doutrinas das três escolas: a acadêmica, a peripatética e a estoica. (D.L. IV, 67).

Se, por um lado, os ataques dos acadêmicos aos estoicos foram realmente contundentes, minuciosos e estudados e conseguiram abalar alguns aspectos do sistema da Stoá, por outro lado, os próprios acadêmicos não passaram incólumes aos contra-ataques estoicos, e Cleanto de Assos (circa 331-232 a.C.) acusou gravemente Arcesilao de não agir conforme dizia que se deveria (D.L. VII, 171), e Crisipo de Sólis (circa 282-206 a.C.) defendeu tão engenhosamente sua escola que tornou-se comum dizer que "sem Crisipo não existiria a escola estoica" (D.L. VII, 183).

Então, considerando que a vigorosa disputa entre os filósofos da média academia e a primeiro estoicismo propiciou a oportunidade de ambas as escolas e filosofias se desenvolverem para se tornarem mais eficientes no combate, devemos, para compreender o debate e os desenvolvimentos conceituais por ele suscitados, fazer um interlúdio sobre um dos agonistas que pouco tratamos aqui, a Stoá.

\subsection{Um interlúdio sobre a filosofia da Stoá}

No anedotário típico do período Helenístico, vemos o fundador da Stoá, Zenão (circa 333-261 a.C.), vindo de Cítio, em Chipre $^{83}$ e retratado como

${ }^{83}$ Os achados arqueológicos na ilha de Chipre nos indicam que ela começou a ser ocupada em torno de 10.000 a.C., tendo sido cobiçada por hititas, assírios e persas, sua localização é estratégica porque permite o acesso dos povos levantinos ao Mar Egeu pelo sudeste. A ocupação por colonos fenícios que buscavam um porto mais avançado no Mediterrâneo Oriental do que os disponíveis na região das atuais Síria e Líbano começou por volta do séc. VIII a.C. Em seguida, quando da expansão persa, a ilha de Chipre passou a ser dominada pelo Império Aquemênida que submeteu os colonos fenícios a taxações excruciantes. Quando, por sua vez, da derrota de Atenas e suas aliadas na batalha de Queronéia pelas falanges macedônicas e do sucessivo clamor de Filipe para que os gregos a ele se juntassem contra os persas, montou-se o cenário para a expansão dos macedônicos e o espalhamento da cultura grega, projeto levado a cabo por Alexandre que, em muitos casos, preferia construir alianças contra os persas (e, em alguns casos, com eles próprios desde que contra Dario III Codomano). Uma importante aliança suscitada pela política de Alexandre foi, de modo geral, com os fenícios para obter, assim, o domínio sobre o mar, coibindo uma possível revolta de Atenas que dispunha de uma grande frota marítima, e também Esparta que permanecia hostil ao domínio macedônico e arquitetava incessantemente um revide contra Alexandre . O avanço da cultura grega engendrado por Alexandre foi razoavelmente bem-vindo entre cipriotas. No ambiente, então, de uma Chipre amplamente helenizada, Zenão, fenício e filho de pais fenícios, cujo pai era um mercador de púrpura que trazia sempre consigo de Atenas livros de e sobre filosofia, acabou tendo em si incutindo o interesse pela filosofia desde pequeno. De modo geral, para mais sobre as Guerras Médicas ver Hist. e sobre a relação entre fenícios e persas ver: 'JIGOULOV, Vadim S. The Social History of Achaemenid Phoenicia: Being a Phoenician, 
mercador, estereótipo de fenício para os gregos, que naufraga perto do Pireu, ele então se dirige para Atenas e vai até uma livraria, fica muito satisfeito com a leitura das Memoráveis de Xenofonte e, no exato momento em que passava por lá o cínico Crates, Zenão pergunta ao livreiro onde poderia encontrar homens como Sócrates, e o livreiro simplesmente aponta para Crates e diz: "Segue aquele homem!"

Dessa forma, o primeiro professor de Zenão foi o cínico Crates (acme 326 a.C.). Possivelmente, o que lhe interessou no cinismo fossem as respostas práticas e imediatas que eles ofereciam face aos vouoí da cidade, tendo em vista que os cínicos, para quem a excelência dos sábios é autossuficiente, rejeitavam como supérfluas todas as convenções sociais e procuravam um estilo de vida indiferente, chegando mesmo a ser escandaloso. De fato, a influência da sua

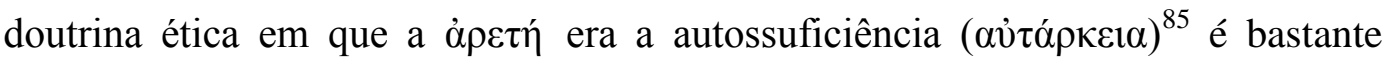
profunda sobre as escolas Helenísticas, contudo em nenhuma outra escola se faz sentir mais do que no estoicismo, de modo que o primeiro e mais controverso dos vinte e sete livros atribuídos a Zenão (a 'República') era uma proposta de reformulação da cidade em que se deveria abolir a maior parte das instituições cívicas, como templos, cunhagem, tribunais, casamentos e diferenças entre os

Negotiating Empires. Londres: Equinox Publishing, 2010’. Uma fonte disponível sobre a expansão fenícia pelo Mediterrâneo e além é 'HANNO. The Periplus of Hanno: A Voyage of Discovery Down the West African Coast (1912 ). Nova Iorque: Cornell University Library, 2009'. Sobre a interação entre gregos e fenícios ver: 'AUBET, Maria Eugenia. The Phoenicians and the West: Politics, Colonies and Trade. Cambridge: Cambridge University Press, 1993'; 'BLASQUEZ, Jose M. Fenicios y cartagineses en el Mediterraneo. Madrid: Ediciones Catedra S.A., 2004'; 'BRANIGAN, Ciaran. The Circumnavigation of Africa. In: Classics Ireland vol. 1. Dublin: Classical Association of Ireland, 1994'; 'FREEMAN, Edward Augustus. The History of Sicily from the Earliest Times: Volume 1. The Native Nations: The Phoenician and Greek Settlements. Boston: Adamant Media Corporation, 2001'; 'WACHSMANN, Shelley. Seagoing Ships \& Seamanship In The Bronze Age Levant (Ed Rachal Foundation Nautical Archaeology). Texas: Texas A\&M University Press, 2008'; 'WARD. The Role of the Phoenicians in the Interaction of Mediterranean Civilizations. Nova Iorque: Syracuse University Press,1995'; 'REED, C.M. Maritime Traders in the Ancient Greek World. Cambridge: Cambridge University Press, 2004'. Sobre a aquisição pelos gregos da tecnologia náutica ver: 'DAVISON, J. A. The First Greek Triremes. In: The Classical Quarterly, Volume 41. Cambridge: Cambridge University Press, 1947 '.

${ }^{84}$ D.L. VII, 2-3.

${ }^{85}$ Ver D.L. VI, 22: 'Conta Teofrasto em seu Megárico que certa vez Diógenes, vendo um rato correr de um lado para o outro, sem destino, sem procurar um lugar para dormir, sem medo das trevas e não querendo nada do que se considera desejável, descobriu um remédio para suas dificuldades. Segundo alguns autores ele foi o primeiro a dobrar o manto, que tinha de usar também para dormir, e carregava uma sacola onde guardava seu alimento; servia-se indiferentemente de qualquer lugar para satisfazer qualquer necessidade, para o desjejum ou para dormir, ou conversar; sendo assim, costumava dizer, apontando para o pórtico de Zeus e para a Sala de Procissões que os próprios atenienses lhe haviam proporcionado lugares onde podia viver'. 
$\operatorname{sexos}^{86}$. Ainda assim, Zenão nunca chegou a propor um estilo de vida inteiramente cínico: homem reservado que era ${ }^{87}$, acabou por tomar a indiferença cínica como austeridade, um princípio muito mais sociável do que o preconizado pelos cínicos e que posteriormente se tornaria elogiável por sua conformidade com os costumes da cidade, enquanto que, de fato, os cínicos se tornariam reprováveis justamente por seu inconformismo.

Outra notável diferença da filosofia de Zenão com relação à dos cínicos é que para os últimos tudo o que se situava entre a excelência e a deficiência era totalmente indiferente, ao passo que para Zenão havia bens (e males) corporais externos que poderiam ajudar (ou dificultar) a obtenção da sabedoria e da felicidade, embora não fossem por si sós desejáveis e alvos morais. A adesão de Zenão a essa concepção e a rejeição parcial da concepção ética cínica foi-lhe incutida por Pólemon e é a maior contribuição da filosofia da academia ao seu pensamento.

Em seguida, talvez buscando uma fundamentação teórica mais forte, Zenão rompeu com os cínicos e passou a ouvir preleções de Estilpo de Megara (circa 360-280 a.C.). Os filósofos megáricos também viam a filosofia como forma de vida e concordavam com a ideia de excelência como autossuficiência embora não fossem tão radicais como os cínicos. Além disso, os megáricos incentivavam a necessidade de um amplo amparo teórico, notadamente acerca de técnicas discursivas para aumentar a capacidade dialética dos adeptos. E também, Estilpo possuía alguns argumentos metafísicos que o levaram a rejeitar os universais ${ }^{88} \mathrm{e}$, por ser um professor afamado e de vasta audiência ${ }^{89}$, fez com esses argumentos se

\footnotetext{
${ }^{86}$ Ver SVF I.

${ }^{87}$ Ver D.L. VII, 3: '[Zenão] era muito tímido para adaptar-se ao despudor cínico. Percebendo essa resistência e querendo superá-la, Crates deu-lhe uma panela cheia de sopa de lentilhas para levar ao longo do Cerameicôs; vendo que ele estava envergonhado e tentava esconder a panela, Crates partiu-a com um golpe de seu bastão. Zenão começou a fugir, enquanto as lentilhas escorriam de suas pernas, e Crates disse-lhe: "Por que foges, meu pequeno fenício? Nada te aconteceu de terrível."

${ }^{88}$ Ver D.L. II, 119: 'Sendo extraordinariamente hábil nas controvérsias, ele negava a validade até dos universais, e dizia que quem afirma a existência do homem não significa os indivíduos, não se referindo a este ou àquele; de fato, porque deveria significar um homem mais que outro? Logo, não quer dizer este homem individualmente. Da mesma forma, "verdura" não é esta verdura em particular, pois a verdura já existia há dez mil anos; logo, "isto" não é verdura.'

${ }^{89}$ Ver D.L. II, 113: 'Pela inventividade em relação a argumentos e pela capacidade sofística [Estilpo] sobrepujou a tal ponto os outros filósofos que quase toda a Hélade tinha os olhos postos nele e aderiu à escola megárica. Sobre ele Fílipos de Megara exprimiu-se textualmente com as seguintes palavras: "De Teofrasto Estilpo conquistou para a sua escola o teórico Metrodoro e Timogenes de Gela; de Aristóteles [filósofo Cirenáico], Clêitarcos e Símias; dos próprios dialéticos conquistou Paiônios; de Aristides, Dífilos do Bósforo, filho de Eufantos, e Mírmex, filho
} 
tornassem muito influentes sobre a epistemologia Helenística, notadamente amplificando a predileção por teorias empiristas.

A outra filiação de Zenão era à escola dialética, um círculo de especialização em lógica e modos de argumentação bastante popular no período Helenístico. Lá, Zenão foi aluno de Diodoro Cronos que popularizou uma coleção de quebra-cabeças que se tornariam centrais na dialética Helenística e, ao mesmo tempo, ele e seus pupilos desenvolveram a lógica proposicional com bastante sucesso.

Bem, munidos agora da informação necessária sobre as filiações de Zenão, passemos adiante e analisemos a fundação do primeiro estoicismo e o teor de suas principais doutrinas, bem como os desenvolvimentos feitos pelos escolarcas da fase média. Assim, nos ateremos à fase que dura cerca de um século e vai de Zenão de Cítio a Crisipo, passando por Cleanto de Assos, quando foi exposta pela primeira vez uma boa parte das teses que vieram a tornar-se o cânone da escola, e também percorreremos brevemente os discípulos de Crisipo, terminando com Panécio e Posidônio, com quem finda a chamada fase média da Stoá.

Conforme demonstrado anteriormente, vindo de Cítio com vinte e dois anos para Atenas em torno de 312 a.C., Zenão buscara uma orientação filosófica de matriz socrática e, após cerca de doze anos perambulando pelas escolas cínica, megárica, dialética e acadêmica ${ }^{90}$, passou a fazer suas próprias preleções na

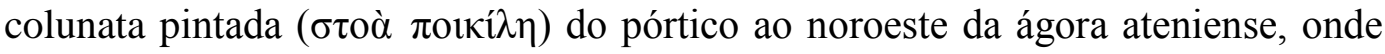
viveu até sua morte em 262 a.C. Portanto, é a ele que se atribui a fundação da escola estoica.

Contudo, não houve de fato a fundação de uma escola da parte de Zenão, antes, houve a formação de um grupo de pensadores em Atenas na virada do século IV para o III a.C. que veio a ser inicialmente apelidado de 'zenonianos'. Não obstante, esse apelido reflete muito mais o predomínio de Zenão nos debates

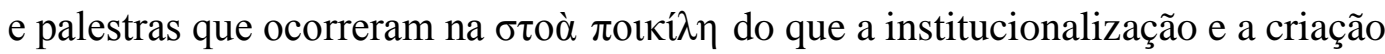
de estruturas formais e oficiais do estoicismo por sua parte. Além disso, as

de Exaínetos; os dois últimos tinham vindo a ele para refutá-lo, porém tornaram-se seus prosélitos devotados." Após o trecho citado ainda há uma longa lista de pensadores influenciados por Estilpo.

${ }^{90}$ Talvez ele tenha também passado pelo Liceu, a influência peripatética sobre Zenão permanece polêmica. Ver: 'SEDLEY, D. A escola, de Zenon a Ário Dídimo. In: INWOOD, B (org.). Os Estóicos. São Paulo: Odysseus, 2006'; e 'SEDLEY, D. Os protagonistas. In: Revista Índice, vol. $02, \mathrm{n}^{\circ} 01-2010 / 1$. 
concepções dos pensadores que compunham o círculo zenoniano eram divergentes e os debates eram mais constantes do que hoje comumente se imagina entre os membros de uma escola ou doutrina qualquer. Será, então, percorrendo as divergências que entenderemos a solidificação gradual do núcleo da filosofia estoica que, sem graves distorções, perdurou até Sexto Empírico (cerca de cinco séculos posterior a Zenão) que tinha uma vasta consciência dessa doutrina.

Desse modo, começamos pela querela com Herilo que

...nasceu em Cartago. Sustentava que o fim supremo ( $\tau \dot{\lambda} \lambda$ os) é o conhecimento, isto é, viver sempre de maneira a fazer da vida conforme ao conhecimento o padrão em tudo e não se deixar enganar pela ignorância. Definia o conhecimento como a faculdade de acolher as apresentações, sem ceder a argumentos; às vezes Herilo dizia que não existe um fim supremo único, mas que este muda de acordo com as circunstâncias e objetivos, da mesma forma que o bronze pode tornar-se uma estátua de Alexandre, o Grande, ou de Sócrates. Distinguia ainda o fim principal do fim secundário; este último pode ser atingido pelos não sábios e o outro somente pelo sábio. O que não é excelência nem deficiência é indiferente. (D.L. VII, 165).

Em suma, Herilo não concordava com Zenão quanto ao fim moral, tendo chegado, inclusive, a fazer-lhe críticas diretas. Outro caso é o do conterrâneo e companheiro de Zenão, Perseu de Cítio, que escreveu diálogos em que os personagens principais, ele próprio e Zenão, eram representados em fervorosa discussão ${ }^{91}$. Todavia, a discrepância mais notável foi a que envolveu Aríston de Quíos, que rejeitava todas as partes da filosofia, exceto a ética e, além disso, alinhava-se explicitamente aos cínicos, recusando assim a noção de que bens corporais externos poderiam ser "vantajosos" (ou, em oposição, "desvantajosos") de acordo com suas capacidades de dirigir as pessoas à virtude ${ }^{92}$. Mas, apesar das discordâncias, houve defensores aguerridos da filosofia de Zenão, o mais notável foi seu discípulo Cleanto de Assos que, quando da morte do mestre, assumiu a liderança dos 'zenonianos', agora definitivamente estoicos. Com a morte de Zenão e a assunção de Cleanto da liderança do movimento coincidem o rechaço e expulsão de Aríston para o Cinosarges, local de reunião dos cínicos. Portanto,

\footnotetext{
${ }^{91}$ Ver Deip. 162 d.

${ }^{92}$ Ver D.L. VII, 160-161: 'Aríston, o Calvo, nasceu em Quíos, e era chamado de sereia. Afirmava que o fim supremo é viver perfeitamente indiferente a tudo que não é excelência ou deficiência, não admitindo distinção alguma entre coisas indiferentes, pois as considerava todas iguais. Comparava o sábio a um ator talentoso que, devendo pôr a máscara de Tersites ou de Agamenon, representa os dois papéis competentemente. Aríston eliminou a física e a lógica, argumentando que a primeira está acima de nossas forças, e a segunda nada tem a ver conosco; somente a ética nos interessa.' Compare com PE 15.62.7-14; e Adv. Log. I, 12.
} 
couberam a Cleanto a construção da rigidez doutrinal em torno da filosofia de Zenão e a rejeição das filosofias que lhe eram opostas ou dessemelhantes quando Zenão ainda vivia.

As primeiras divergências podem, assim, nos indicar elementos da doutrina de Zenão que viriam a ser canonizados por Cleanto:

1- da divergência com Herilo, que dizia que não existe um fim supremo único, podemos concluir que Zenão defendia que havia tão-somente um

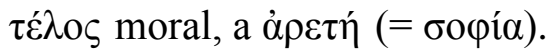

2- Da divergência com Aríston, que defendia a rigorosa indiferença de todos

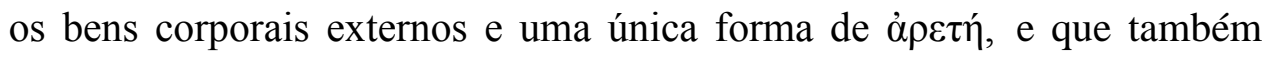
exaltava a ética em detrimento da lógica e da física, podemos concluir que Zenão, por sua vez, conferia alguma importância aos bens corporais externos. Além disso, ele pensava que a filosofia era composta por três partes, a saber, física, lógica e ética.

Da mesma forma, se nos recordarmos das filiações de Zenão e de como essas viriam a influenciá-lo — o austero cinismo, com a noção de que o fim supremo moral é exclusivamente a excelência; o megarismo, com a apologia ao amparo teórico e a rejeição dos universais; a academia, com a concepção de que há bens e males corporais externos; e os dialéticos, com os rudimentos da lógica proposicional - poderemos reconstruir o funcionamento do sistema da primeira Stoá que se tornou célebre pela concepção da filosofia como tripartida e que recolocava em cena a preocupação com um tema que fora parcialmente marginalizado por Sócrates e o socratismo: a física. Ainda assim, os estoicos persistiram concordando com os predecessores socráticos ao entenderem que as mais importantes reflexões filosóficas são as que concernem à moral, em que, por seu turno, viver bem e ser feliz é viver virtuosamente e em conformidade com a natureza, propiciando o alcance da excelência.

Assim, urgiria a necessidade de conhecer a natureza para agir em consonância com seus desígnios. Eis a relevância fundamental do conhecimento: é ele o responsável por unir a finalidade moral do sistema estoico - a vida feliz, que é a vida virtuosa e excelente vivida em conformidade com a natureza - com a própria natureza, que precisa ser interpretada através de uma física. Por sua vez, 
os critérios e parâmetros que validam ou repudiam formas de conhecer o real e a verdade são lançados e fundamentados por uma lógica que inclui teses epistemológicas. Antes, porém, de nos concentrarmos nas teses que compõem o sistema da doutrina estoica, passemos brevemente em revista a vida e obra do seu segundo escolarca, Cleanto de Assos, e também as do seu sucessor, Crisipo, considerado por muitos o mais importante pensador da Stoá, faremos também algumas considerações sobre o médio estoicismo, já que importantes teses foram suprimidas ou acrescidas ao seu sistema pelos pensadores que serão citados.

Assim, imediatamente após Zenão na linha sucessória de escolarcas da Stoá tem-se Cleanto, oriundo de Assos, na atual Turquia, que se tornou líder da escola (circa 260 a.C) e foi o autor do primeiro livro estoico a sobreviver, o 'Hino a Zeus', que é preservado por Estobeu ${ }^{93}$ e é um tratado religioso. Cleanto também foi autor de duas obras sobre a física de Zenão e de quatro obras sobre Heráclito ${ }^{94}$, assim, o filósofo de Assos foi o responsável pela transmissão da ampla influência de Heráclito sobre a física estoica, e também por suas por consequências teológicas mais profundas.

O terceiro escolarca do estoicismo em Atenas foi Crisipo de Sólis, na Ásia Menor. Ele sucedeu Cleanto em torno de 230 a.C. e liderou a escola até sua morte com a idade de setenta e três anos, em torno de 200 a.C. Como já mostramos, Diógenes Laércio resume bem sua importância para a Stoá ao dizer que "se não houvesse Crisipo, não haveria Stoá" (D.L. VII, 183), tendo em vista que ele foi o homem que elaborou as mais sólidas defesas da escola contra os vigorosos ataques céticos da média academia, sem as quais a inconsistência do estoicismo teria sido atestada, precipitando sua ruína, assim, Crisipo foi responsável por nada mais nada menos do que a própria sobrevivência da Stoá. Além disso, a ele se devem os arrojos e arremates nas concepções estoicas sobre a linguagem, incluindo suas disciplinas, como: gramática, lógica e etimologia, inventada por ele. Ademais, a Crisipo couberam a revisão da teoria estoica do conhecimento,

${ }^{93}$ De longe a melhor edição de João Estobeu é 'STOBAEUS. Anthologium. Wachsmuth, O. Hense (ed.). Berlim: Weidmann, 1912'. Contudo, Wachsmuth compilou os dois trabalhos de Estobeu (Éclogas e Florilégio) em um único (Antologia). Então, nos referiremos sempre às obras de Estobeu com abreviaturas que respeitem a sua divisão, sendo respectivamente: Ecl. e Flori. Há a tradução do 'Hino', conforme preservado por Estobeu, para o inglês em: 'INWOOD, B.; GERSON, L. P. Hellenistic Philosophy: Introductory Readings. Indianápolis: Hackett, 1997' e 'LONG, A. A.; SEDLEY, D. N. The Hellenistic Philosophers. Cambridge: Cambridge University Press, 1987'.

${ }^{94}$ Ver D.L. VII, 175. 
que se tornou oficial em detrimento da teoria do próprio Zenão, e a criação de uma coesão maior entre as partes que compõem o sistema filosófico da escola. Como se não bastasse, Crisipo foi um escritor prolífico com cerca de setecentos livros a ele atribuídos, dos quais somente fragmentos citados por outros autores sobreviveram, entre eles, Plutarco e Galeno, que escreveram livros contra ele ${ }^{95}$, e Sexto Empírico. De Crisipo há ainda fragmentos recentemente descobertos em rolos de papiro escavados em Herculano ${ }^{96}$, como partes de suas obras ' $D a$ Providência' e 'Questões Lógicas'97.

Após Crisipo, temos Zenão de Tarsos (escolarca em circa 205 a.C.), mestre de Diógenes da Babilônia que veio a se tornar escolarca da Stoá em Atenas (circa 155 a.C.). Ao babilônico Diógenes cabem os méritos de ter sido o primeiro a escrever manuais de termos éticos e dialéticos estoicos e também tratados contendo defesas dos complicados silogismos de Zenão de Cítio à luz dos desenvolvimentos da lógica suscitados por Crisipo. Diógenes também fez a reflexão estoica incidir sobre a teoria musical, propiciando um sincretismo com antigas teorias pitagóricas sobre o assunto, e a retórica, propiciando um sincretismo com a teoria aristotélica sobre o assunto ${ }^{98}$. A música e a retórica se tornariam, assim, graças a Diógenes, ciências liberais incorporadas pelo sistema da Stoá ${ }^{99}$, mas talvez sua maior importância tenha sido a de introduzir a Stoá à

\footnotetext{
${ }^{95}$ Ver de Plutarco Com. Not. e St. Rep. De Galeno ver PHP.

${ }^{96}$ Herculano foi uma das cidades que, assim com Pompéia, foram carbonizadas com a erupção de 79 d.C. do Vesúvio. O efeito da erupção propiciou o embalsamamento das pessoas que estavam nas cidades, e também da biblioteca do epicurista Filodemo de Gadara, contendo cerca de mil e oitocentos rolos de papiro na maioria sobre filosofia, cuja decifração é particularmente difícil por que é quase impossível desenrolá-los sem causar sua destruição total ou parcial. Contudo, há um projeto encabeçado pelo professor de engenharia da informática Brent Seales (U K) que está em fase de testes e pretende digitalizar os papiros através de raios-X sem que seja preciso desenrolálos (ver: http://latunicadeneso.wordpress.com/2009/05/19/leyendo-los-rollos-de-papiro-deherculano/). Para mais ver a edição especial do Boletim de Estudos Clássicos da Universidade de Londres sobre papirologia grega e latina: 'Bulletim of the Institute of Classical Studies. Special Issue: Institute of Classical Studies, Bulletim Supplement $n^{\circ}$ 54: Greek and Latin Papyrology. Londres: School of Advanced Studies, University of London, 1986', e também: 'GIGANTE, M. (org.) La Villa dei Papiri. Nápoles: 1983' e 'GIGANTE, M. La bibliothèque de Philodème et l'épicurisme Romain. Paris: Les Belles Lettres, 1987'.

${ }^{97}$ Sobre Zenão e seus discípulos diretos, inclusive os dissidentes Aríston de Quíos, Apolófanes, Herilo de Cartago, Dionísio de Heracléia e Perseu de Cítio, passando por Cleanto e Sfairos ver $S V F$ I. Por sua vez, os muitos fragmentos de Crisipo aparecem em todo $S V F$ II e no começo de SVF III (Chrysippi fragmenta moralia).

${ }^{98}$ Para uma demonstração de como o estoicismo veio a absorver certos termos e teorias pitagóricas ver $A d v$. Log. I. Para mais sobre a teoria musical estoica e seu envolvimento com o sistema da escola ver $A d v$. Mus. Sobre a incorporação da retórica ao sistema ver Adv. Rhet.

${ }^{99}$ Sobre o tratamento de Diógenes da teoria musical e da retórica ver Ind. St. Herc. e também SVF

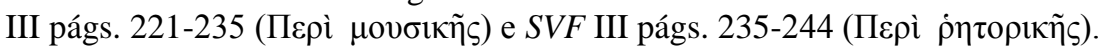


Roma, quando do célebre episódio da ida da embaixada dos filósofos gregos ao senado romano.

Depois de Diógenes da Babilônia temos Antipater de Tarsos ${ }^{100}$ (circa 152 a.C.), que foi o primeiro a tentar alinhar a doutrina da Stoá à doutrina da academia através de um sincretismo com o platonismo para evitar, ou pelo menos diluir, os cáusticos ataques de Carnéades. Antipater de Tarsos argumentou a favor da afinidade entre o fim moral estoico e o acadêmico, alegando que esse fim conforme pensado por Zenão - é idêntico ao fim pensado por Platão, tendo sobre isso escrito um livro 'Sobre a doutrina de Platão de que só o que é virtuoso é bom', ademais, ele foi o primeiro estoico a escrever sobre as "propriedades", que são, grosso modo, o correlato da Stoá às formas platônicas. Mas o ecletismo só veio a atingir efetivamente a Stoá com Panécio.

Originário de Rodes, discípulo de Antipater e escolarca da Stoá entre 129 e 110 a.C., Panécio lia e comentava escritos de Platão e Aristóteles a luz da filosofia estoica, foi um filósofo muito influente mesmo entre pensadores romanos, por exemplo Cícero cujo livro 'Sobre os Deveres' (De Officiis) é um comentário de

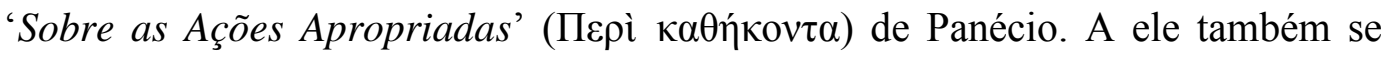
devem importantes revisões da doutrina da escola, como a rejeição do dogma da

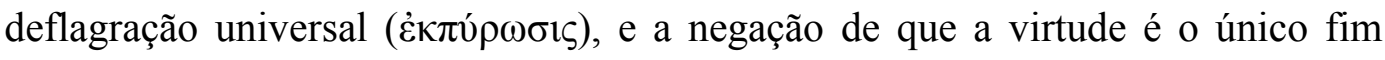
moral desejável, mas, por outro lado, Panécio foi um defensor de outras doutrinas estoicas, como a da mortalidade da alma, resistindo nesse aspecto ao sincretismo com o platonismo e o pitagorismo Helenísticos. Outra importante contribuição de Panécio que veio a marcar profundamente o método de abordagem da Stoá e o ensino de sua doutrina foi fazer com que a ética estoica se voltasse para questões mais práticas e corriqueiras, ao invés de se voltar exclusivamente para o seu projeto inicial de aspirar à virtude do sábio idealizado.

Aprofundando o sincretismo com o platonismo e o aristotelismo, temos o pupilo de Panécio, Posidônio, nascido em Apamea na Síria em circa 135 a.C. Um aspecto interessante que a filosofia da Stoá adquire sob Panécio e que se acentua

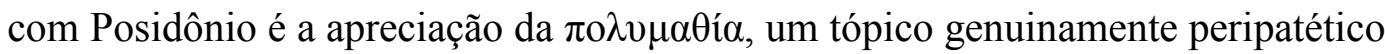
que vem a ser relido pelos estoicos e que faz com que várias disciplinas que outrora estavam excluídas do âmbito das investigações da escola se tornassem

\footnotetext{
${ }^{100}$ Os fragmentos de Zenão de Tarsos, Diógenes da Babilônia e Antipater de Tarsos, bem como de outros discípulos de Crisipo aparecem compilados em SVF III.
} 
pertinentes. Assim, sob a física se agregariam as seguintes disciplinas: cosmologia, astronomia, teologia, metafísica, medicina e psicologia. Sob a lógica se agregariam a epistemologia, a retórica, a gramática, a etimologia, a lógica proposicional, a teoria da prova, a geometria, a aritmética e a música. E na parte ética

da virtude toda pode ser dito que consiste de três coisas, das quais a primeira é preceber o que em cada coisa é verdadeiro e real, com o que se relaciona, o que acarreta, pelo que é causada e do que é causa; a segunda é coibir os movimentos conturbados da alma, que os gregos chamam $\pi \dot{\alpha} \theta \eta$, e tornar os impulsos [appetitiones], que eles chamam ópuós, obedientes à razão; a terceira é tratar com moderação e sabedoria aqules com os quais congregamos, para que possamos, com sua cooperação, obter e acumular as coisas que nossa natureza deseja ... (De Off. 2, 18).

Posidônio também se alinhou a uma cosmologia platônica originada na interpretação do 'Timeu' e rejeitou a noção tão cara a Crisipo do monismo da alma corpórea ao preferir a noção de alma tripartite de Platão, mas essa aproximação da doutrina de Platão era seletiva e não se pretendia erigi-lo ao posto de patrono do estoicismo, ao invés disso, as atenções de Posidônio se voltavam para o interlocutor pitagórico do 'Timeu', tratava-se mais uma vez de alinhar a Stoá à doutrina de Pitágoras, mas agora através de Platão. Por sua vez, essa reverência pelo pitagorismo de modo algum era uma inovação de Posidônio,

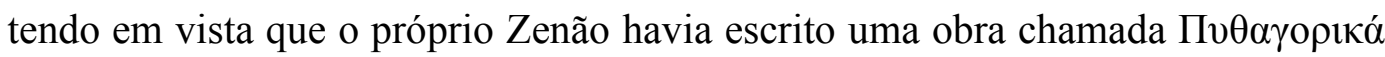
sobre a qual nada se sabe ${ }^{101}$, desse modo, Posidônio poderia ser inovador quanto à cosmologia e psicologia estoicas, aderindo a um posicionamento derivado de sua interpretação de Platão, sem ser totalmente heterodoxo porque considerava as posições que adotava como derivadas, na verdade, do pitagorismo, que era apreciado mesmo por Zenão, o fundador da Stoá. Ademais, Posidônio também foi mestre de Cícero.

Tendo considerado aspectos das vidas e obras dos pensadores supracitados, esperamos que se possa compreender como, quando e por quem foram criadas ou desenvolvidas as, para nós, mais relevantes contribuições à filosofia da Stoá enquanto sistema.

Vale ressaltar, quanto aos filósofos estoicos da fase romana, que não foram citados porque buscávamos demonstrar os primeiros desenvolvimentos teóricos da

${ }^{101}$ Ver D.L. VII, 4. 
filosofia estoica. Os estoicos romanos, com a exceção de Epicteto, serão citados somente quando necessário. Voltemos, agora, às doutrinas filosóficas da Stoá.

\subsection{O sistema filosófico tripartite da Stoá}

A filosofia estoica foi, desde Zenão, definida como um sistema composto pelas partes física, lógica e ética ${ }^{102}$. Nunca houve, contudo, acordo entre os filósofos da escola sobre qual a parte principal, e tampouco sobre qual a parte que deveria ser ensinada primeiro ${ }^{103}$. Assim,

Os estoicos dividem a filosofia em três partes: física, ética e lógica. Essa divisão aparece pela primeira vez no livro Sobre a Lógica, de Zenão, depois em Crisipo no primeiro livro Sobre a Lógica e no primeiro livro Sobre a Física (...) Outros estóicos, entretanto, dão o primeiro lugar à lógica, o segundo à física e o terceiro à ética. Entre estes estão Zenão em seu tratado Sobre a Lógica, Crisipo, Arquedêmos e Êudromos.

Diógenes de Ptolemaís, por seu turno começa pela ética, mas Apolodoro põe a ética em segundo lugar; Panécio e Posidônio começam pela física... (D.L. VII 3941).

Mas, apesar das divergências, há símiles que podem nos indicar algo sobre o mecanismo do sistema da Stoá:

Os estoicos comparam a filosofia a um ser vivo, onde os ossos e os nervos correspondem à lógica, as partes carnosas à ética e a alma à física. Ou então a comparam a um ovo: a casca à lógica, a parte seguinte (a clara) à ética, e a parte central (a gema) à física. Ou a comparam ainda a um campo fértil: a cerca externa é a lógica, os frutos são a ética, e o solo ou as árvores são a física. Ou a comparam a uma cidade bem amuralhada e racionalmente administrada. E nenhuma parte é

${ }^{102}$ E assim permaneceu, como podemos ver em Plac. 874 E-F: 'Os estoicos sustentaram que a sabedoria é um conhecimento de coisas divinas e humanas, e que a filosofia é a prática de uma habilidade útil. A virtude unicamente e em sua mais alta expressão é útil, e as virtudes mais genéricas são três: a física, a ética e a lógica. Eis porque a filosofia também tem três partes: a física, a ética e a lógica. Fazemos física quando investigamos o que é relativo ao cosmos e ao que está nele, ética quando dedicamos nosso tempo ao modo de vida humano, lógica quando o dedicamos ao discurso, ao que denominam também "dialética".

${ }^{103}$ Crisipo, por exemplo, pensava que o ensino das partes do sistema deveria funcionar da seguinte forma: 'Crisipo crê que os jovens têm que ouvir conferências sobre lógica primeiro, em segundo lugar sobre ética, e em terceiro lugar sobre física; e, finalmente, devem ocupar-se de discursos sobre os deuses como a culminação desses estudos. Sem embargo, mesmo que em muitos lugares isto já houvesse sido dito, basta citar o que se encontra literalmente assim no livro IV de sua obra Sobre os Modos de Vida: "Agora bem, parece-me primeiramente que, de acordo com o que corretamente disseram os Antigos, os tipos de investigações teóricas dos filósofos são três: umas lógicas, outras éticas e outras físicas. Segundo, que destas as lógicas devem ser postas em primeiro lugar, as éticas em segundo e as físicas em terceiro lugar. Entre as físicas, o discurso concernente aos deuses é o último. Por isso também as suas transmissões foram chamadas de iniciações”. (St. Rep. 1035 A). 
separada das outras, como dizem alguns estoicos, mas, ao contrário, todas estão estreitamente unidas entre si.

Seu próprio ensino fazia-se conjuntamente. (D.L. VII 40).

Mesmo que sejam obscuros e não nos ajudem a especular qual a parte mais importante do sistema, os símiles do ser vivo e do ovo revelam a interdependência $^{104}$ orgânica entre as partes. Ora, é justamente por essa organicidade que esses símiles se tornaram preferíveis para alguns membros da escola:

... as abordagens daqueles que dizem que uma parte da filosofia é física, outra ética, e a outra lógica parecem ter sido mais completas. Desse grupo, Platão é, com efeito, o fundador, tendo em vista que ele engajou-se na discussão sobre muitas questões em física, muitas em ética, e não menos em lógica. Mas os mais explícitos aderentes a essa divisão são Xenócrates, os peripatéticos e os estoicos. Por isso eles, de maneira implausível, comparam a filosofia com um jardim coberto de frutas, de modo que a parte física pode ser ligada ao cume das árvores, a parte ética à suculência dos frutos, e a parte lógica à força dos muros. Outros dizem que é como um ovo; ora, a ética é como a gema, que algumas pessoas dizem que é o frango, a física é como a clara, que é comida para a gema, e a lógica é como a casca externa. Mas, tendo em vista que as partes da filosofia são inseparáveis umas das outras, enquanto que as plantas são consideradas distintas dos seus frutos e os muros são separados das plantas, Posidônio pensou ser mais apropriado ligar a filosofia a um animal, a parte física sendo ligada ao sangue e à carne, a parte lógica aos ossos e tendões, e a parte ética à alma. ( $A d v$. $\log$. I 16-19).

Por seu turno, a comparação com o campo fértil revela o papel da lógica (cerca externa) de defender as concepções da escola, a fundamentação básica das doutrinas em uma compreensão da natureza, dado que a física é representada como o solo e as árvores que, se adequadamente cultivadas, produzem aquilo que pode, enfim, ser colhido pelo homem, os frutos. A comparação com a cidade fortificada, racionalmente administrada, demonstra a reivindicação da possibilidade de defender-se através do uso vigoroso da razão, justificando a adjetivação da filosofia estoica como intelectualista.

Contudo, se considerarmos que o objetivo do estoicismo é ético: a excelência ou virtude, que, uma vez alcançada, faz do homem um sábio, e,

\footnotetext{
${ }^{104}$ A interdependência argumentativa (e não somente orgânica) das partes da filosofia da Stoá também pode ser deduzida de De Fin. III 74: 'Em verdade, me atrai a admirável disposição do sistema e a surpreendente ordem dos assuntos. Pelos deuses imortais! Não os admiras? Pois, o que se pode encontrar, seja na natureza - onde nada pode ser mais convenientemente organizado ou nas produções que dependem da ação humana que seja tão sistemático, bem construído e unido? Qual conclusão não se segue à sua premissa? Que consequência há que não se segue do que a antecede? Há algo que não se encontra conectado causalmente com outra coisa a tal ponto que, se altera-se tão-somente uma letra, tudo se derruba?
} 
ademais, que sábios estoicos jamais cometem erros, por que estão seguros da estrutura providencial do mundo (física) que é igual ao destino e que é o mesmo que a vontade de Zeus, concluiremos que a garantia da serenidade do sábio advém da ordenação da vida através do conhecimento da natureza. Então, para ser sábio é preciso estar municiado de uma epistemologia (lógica) forte que indique com segurança a verdade, mesmo que dela se aproxime gradualmente.

A importância da lógica como elemento que interliga a física e a ética poderia servir para justificar um tratamento das partes que compõem o sistema da Stoá a partir dela ${ }^{105}$, não é essa nossa opção. Pensamos que se a física e a ética são de alguma forma correspondentes, tendo em vista que a norma para a vida é extraída do funcionamento da própria púøıs, então é pelas teses físicas que devemos começar.

\subsection{A física estoica}

Para os estoicos a física é a parte da filosofia que lida com o que de modo

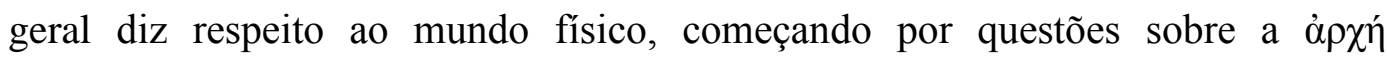
originária e incluindo ciências empíricas como a astronomia e a medicina, mas não somente isso. Remonta ao próprio Zenão a asserção mais básica e fundamental dessa parte do sistema de que "tudo o que existe é corpóreo", por que, para ele, ser ou existir devem ser identificados com a corporeidade, assim, mesmo coisas que usualmente poderiam ser consideradas incorpóreas, como a alma, a justiça e a virtude são tidas como corpóreas pelo estoicismo. Então, ao invés de atribuir existência somente ao que é fisicamente corpóreo, que propiciaria a rejeição automática da existência de coisas não físicas, como a excelência, gerando um problema, a solução de Zenão foi incluir algumas dessas coisas não físicas na categoria de corpóreos, como se fossem, por sua vez, coisas físicas.

Ademais, para Zenão, há coisas que podem ser reais, mas que não são corpos e que, portanto, não existem de acordo com a ontologia materialista estoica, mas que, não obstante, podem ser reais. Estes incorpóreos são quatro

${ }^{105}$ Como faz Sexto Empírico: '... em toda parte da filosofia o que deve ser buscado é a verdade, pode-se, acima de tudo, ter pontos de partida e processos para discernir o que é confiável. Mas a 
entidades que os estoicos não se arriscariam a afirmar que são nada, mas que não são corpos, embora sejam algo: o vazio, o tempo, o lugar e os "dizíveis" ou “exprimíveis" ( $\lambda \varepsilon \kappa \tau \alpha ́)$, assim, essas entidades são reais apesar de serem inexistentes, são objetos do pensamento ${ }^{106}$ e como tal, ao invés de existirem, subsistem, elas são entidades reais, mas fazem parte de uma realidade não existente.

Voltando à categoria dos corpóreos, cabem nela todas as coisas que têm a capacidade de agir ou de sofrer ação ${ }^{107}$, entre as quais estão: a virtude, a justiça e também paus e pedras. Então, para os estoicos, há o gênero ontológico supremo que inclui todas as entidades reais, abaixo do qual há as classes dos existentes (corpóreos) e dos inexistentes (incorpóreos), mas que são subsistentes ${ }^{108}$. Eis o sentido de uma das influências megáricas sobre o estoicismo: a rejeição dos universais, pois o gênero supremo é o dos reais, então, individualmente, os objetos são incluídos nesse gênero, divididos de acordo com as classes, de modo que

lógica é a área que contém reflexão sobre critérios e demonstrações; então nesta é onde devemos fazer nosso ponto de partida.' (Adv. Log. I 24).

${ }^{106}$ Ver Adv. Gram. 19.

${ }^{107}$ Essa espécie de critério para a corporeidade aparece como um postulado emitido da boca do próprio Zenão em Acad. pr. 39 em uma discussão sobre física: 'Sua posição acerca dos princípios naturais foi a que se segue. Primeiro, ele não aceitou a adição aos quatro elementos daquela quinta natureza que seus predecessores imaginaram como a fonte dos sentidos e da mente: ele declarou que o fogo foi a natureza que trouxe todo ao ser, e também a mente e os sentidos. Uma segunda discordância com deveu-se à sua crença de que era impossível para algo sofrer uma ação causada por algo incorpóreo (que é o que Xenócrates afirmou, juntamente com seus predecessores, que a mente era): o que age e o que sofre não poderiam ser incorpóreos.'

108 Essa definição persistiu até o estoicismo romano, embora já houvesse a tendência eclética favorável a Platão em que o "gênero supremo", "o que existe", é entendido como um universal, diluindo o nominalismo de Crisipo que era muito aparente na primeira fase da Stoá. Ver Ep. 58, 11-15: 'Todavia, há algo anterior ao corpo, pois dizemos que enquanto algumas coisas são corpóreas, outras são incorpóreas. Portanto, qual seria o gênero do qual se derivam? Aquele ao qual conferimos outrora um nome pouco apropriado: "o que é". Assim, com efeito, se dividiria em três espécies, de modo que dizemos: "o que é" é ou bem corpóreo ou bem incorpóreo. Este é, por conseguinte, o gênero primeiro e mais importante e, por assim dizer, universal; os demais gêneros são, sem dúvida, gêneros, mas particulares, como homem é um gênero [...] Aquele gênero, "o que é", é universal, pois não tem nada sobre ele; é o princípio das coisas, e todas as coisas a ele se subordinam.' Alexandre de Afrodisias, apesar de ter nascido cerca de cento e trinta anos após a morte de Sêneca, parece ter tido acesso a fontes mais antigas do estoicismo do que o próprio Sêneca que, ademais, estava imerso nas discussões da própria escola e comprometido com suas próprias interpretações. Assim, Alexandre não trata "o que é" como universal, mas como um gênero mais geral: 'Deste modo, poder-se-ia mostrar que os da Stoá não postulam adequadamente o algo como gênero do ser, pois se é algo, é algo, obviamente também um existente. Mas, se é um existente, poder-se-ia admitir o enunciado do existente. Aqueles, sem embargo, ao estabelecerem para si mesmos que o que existe se diz só dos corpos, poderiam evitar a dificuldade. É por isso, com efeito, que sustentam que o algo é mais genérico, dado que não se predica somente dos corpos, mas também dos incorpóreos.' (in Top. 301, 19-302, 2). Sexto Empírico parece concordar com a forma de exposição do problema lançada, ou pelo menos utilizada, por Alexandre de Afrodisias, como se pode ver em Adv. Gram. 15- 19. 
somente particulares individuais existem ${ }^{109}$. Contudo, apesar dessa forma de nominalismo, ainda haveria a tentação da linguagem de expressar as qualidades afins entre certos objetos (como cores) através de conceitos generalizantes (como vermelho, amarelo e etc.).

Então, adotando uma postura nominalista mais radical ainda do que a de Zenão, Crisipo lançou fora até mesmo o uso de nomes comuns como "homem", que poderiam causar a impressão de adesão aos universais, e reformulou os proferimentos de forma a não sermos involuntariamente levados à assunção de sua existência. Assim, ao invés de dizermos que o "homem é um animal racional", deveríamos dizer que "se algo é um homem, então esse algo é um animal racional", possibilitando a indicação de uma propriedade comum compartilhada por todos os homens sem a necessidade de se assumir a existência da entidade genérica "homem"110 através do argumento do ninguém ${ }^{111}$, cujo objetivo é negar que "homem" refere-se a qualquer coisa.

Voltando à definição de corpóreo como o que age e que sofre ações, podemos entender alguns pontos tradicionais acerca da cosmologia dos estoicos,

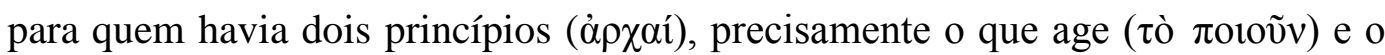
que sofre ações ( $\tau$ ò $\pi \alpha ́ \sigma \chi o v)$, que são deus e a matéria:

De acordo com os estoicos, os princípios são dois: o ativo e o passivo. O princípio passivo é a essência sem qualidade - a matéria —; o princípio ativo é a razão na matéria, ou seja, deus. E deus, que é eterno, é o demiurgo criador de todas as coisas no processo relativo à matéria. Essa doutrina é exposta por Zenão de Cítio na obra Da Substância, por Cleanto na obra Dos Átomos, por Crisipo na parte final do primeiro livro da Física, por Arquedêmos na obra Dos Elementos e por Posidônio no segundo livro de sua Física. Conforme os estoicos, há uma diferença entre princípios e elementos: os princípios não foram gerados e são incorruptíveis, enquanto os elementos se corrompem quando ocorre a conflagração do cosmos. Além disso, os princípios são incorpóreos e informes, enquanto os elementos têm uma forma determinada. (D.L. VII 134). ${ }^{112}$

\footnotetext{
${ }^{109}$ Ver in Metaph. 104, 21.

${ }^{110}$ Para a crítica mais fundamental a essa artimanha de Crisipo ver Adv. Eth. 8-10: 'Os lógicos profissionais asserem que a definição difere do universal meramente em sua construção verbal, sendo idêntica em significado. E certamente; pois aquele que diz "o homem é um animal mortal, racional", diz o que é idêntico em significado, embora diferente em palavras, daquele que diz "qualquer coisa que seja o homem, essa coisa é um animal mortal, racional”. E isto está claro dado o fato de que não somente os universais são inclusivos dos particulares, mas a definição também se estende a todas as instâncias particulares da coisa em questão, aquela do homem, por exemplo, a todos os homens particulares, e aquela do cavalo, a todos os cavalos.'

${ }^{111}$ Eis o argumento: "Se alguém está em Megara, não está em Atenas; mas há um homem em Megara; logo, não há um homem em Atenas." (D.L. VII, 187).

112 Há muitos fragmentos Antigos sobre os dois princípios da física da Stoá, cito apenas mais um: 'Heráclito de Éfeso disse que o fogo é o elemento, Tales de Mileto, a água, Diógenes de Apolônia e Anaxímenes, que é o ar, Empédocles da Ácraga, o fogo, o ar, a água e a terra, Anaxágoras de
} 
É muito discutível a origem da cosmologia estoica, por exemplo, em Acad. pr. 24-29, há a exposição por Marco Terêncio Varrão da doutrina física da velha academia, cito aqui apenas um trecho do parágrafo 24 :

Seu [da velha academia] tratamento da natureza - a segunda parte da filosofia os levou a dividi-la em duas coisas, com uma ativa e a outra se emprestando a si própria para ela [a ativa] e assim [a passiva] sofre dela, de alguma maneira, a ação.

Assim, cogita-se que, nesse ponto da física estoica, a academia, sob Pólemon, tenha influenciado o pensamento de Zenão. Outra notável influência foi a de Heráclito, aprofundada por Cleanto, contudo, o próprio Zenão já identificava o princípio ativo com o fogo ${ }^{113}$ que seria, mais tarde, substituído pelo $\pi v \varepsilon \tilde{v} \mu \alpha$ de Crisipo.

Estranhamente, apesar de haver dois tipos de corpóreos que desempenham distintos papeis cosmogônicos, um ativo (deus) e outro passivo (a matéria), fontes antigas $^{114}$ nos relatam que os estoicos eram monistas estritos, de modo que tudo que é corpóreo é, para eles, parte de uma mesma coisa, a pv́бıs. Mas isso que poderia ser visto como uma problemática adicional, na verdade, só vem a acrescentar a ideia de que, de fato, tudo o que faz parte do conjunto dos corpóreos é o mesmo, embora, para efeitos de elucidação, haja um corpóreo ativo e outro

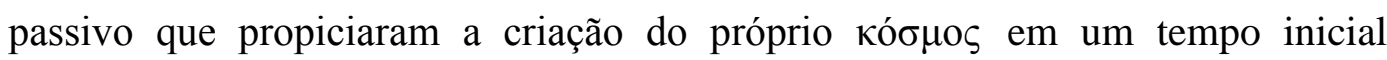
incorpóreo. Ademais, não obstante todos os corpóreos serem definidos como ativos ou passivos, não há, por parte dos estoicos, uma rigidez que nos aponte quais os corpóreos que são sempre ativos e que, portanto, são causalmente sempre anteriores aos corpóreos que são sempre passivos, isso por que não há corpóreos "sempre ativos" ou "sempre passivos", todos os corpóreos sofrem ações originadas em outros corpóreos e causam ações a outros corpóreos, de modo que as relações causais entre eles são extremamente imbricadas ${ }^{115}$.

Voltando, então, ao $\pi v \varepsilon \tilde{u} \mu \alpha$, os estoicos sublinhavam que havia dele três condições, refletindo graus de tensão ( $\tau o ́ v o \imath)$. A primeira é a força que dá unidade

Clazômena, as homeomerias de cada coisa, e os estoicos, que são a matéria e deus.' (Dio. Oen. Phy. 6 I 10-II 9).

${ }_{113}$ Conforme podemos ver em ND III 35.

${ }^{114}$ Ver in Tim. 293.

115 A imprevisível imbricação causal entre os corpóreos propicia o fecundo ataque cético de Enesidemo (contra os etiologistas) que aparece em P.H. I 180-185. 
a um objeto físico $\left(\check{\varepsilon}_{\xi} \xi \varsigma\right)$, mantendo coesas suas partes componentes, a segunda é a força por meio da qual existe a vida e se constitui o seu princípio ( Finalmente, a terceira forma de $\pi v \varepsilon v \tilde{\mu} \alpha$ é aquela que gera o princípio da vida em animais e em seres que possuem a capacidade de percepção, sendo suscetíveis às

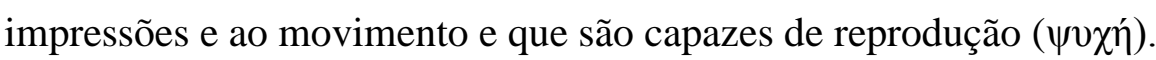

Por outro lado, dado que o $\pi v \varepsilon \tilde{\mu} \mu \alpha$ se identifica com Zeus, é possível entender a doutrina física da Stoá como um tipo de panteísmo, onde deus é concebido como uma força diretiva providente. O viés físico/teológico foi aprofundado por alguns filósofos da escola como Cleanto de Assos, de quem citamos agora parte do 'Hino a Zeus':

Zeus, de tudo provedor, tu, das nuvens escuras, do flamígero trovão, Salve os homens da sua funesta inexperiência

E disperse-a, pai, para longe das suas almas; garanta que eles alcancem A sabedoria com a qual tu confiantemente guias a todos com justiça Poderemos, assim, recompensar-te com honra a honra que nos dá, Louvando tuas obras continuamente, como cabe a nós, mortais... (Ecl. I 1, 12 = SVF I 5 B 537, 25-30).

Apesar de inicialmente se poder estranhar a aproximação entre uma física naturalista e a teologia, esse estranhamento é anacrônico, assim, o deus estoico é um deus na natureza e ambos são seres vivos (D.L. VII 142), de modo que nos fragmentos estoicos onde se lê “deus” é possível substituir essa palavra por "natureza". Além disso, o deus (que é o próprio cosmos) tem consciência, como nos relata Cícero:

Esses argumentos expandidos por nossa parte foram condensados por Zenão da seguinte maneira: "aquilo que emprega a razão é melhor do que o que não emprega. Ora, nada é superior ao cosmos; portanto, o cosmos emprega a razão". Através de um argumento similar pode ser fundamentado que o cosmos é sábio, e abençoado, e eterno, pois todas as incorporações desses atributos são superiores àquelas sem eles, e nada é superior ao cosmos. (ND II 21).

Em uma passagem imediatamente posterior à citada acima, Cícero prossegue sua exposição da física da Stoá, atribuída ao próprio Zenão, em que o deus/cosmos, além de corpóreo, vivo, sábio, abençoado e eterno é um ser sensível: 
Nada que é privado de sensação pode conter algo que possui sensação. Ora, algumas partes do cosmos possuem sensação; portanto o cosmos não é privado de sensação (ND II 22). ${ }^{116}$

Ademais, o cosmos vivo é um ser esférico e rodeado por um vazio infinito $^{117}$. A necessidade de se postular o vazio infinito como redoma do cosmos finito é discutível, mas ao percorrermos os pormenores do problema segundo o estoico Cleomedes (em todo Cael.), vemos que o postulado do vazio infinito incorpóreo circundante fora utilizado como argumento contra uma versão da cosmogonia pitagórica atribuída a Arquitas de Tarento, para quem o cosmos era infinito e que, então, perguntava o que aconteceria se chegássemos à borda do cosmos finito e lá esticássemos nossos braços ${ }^{118}$. Mas, além de evitar críticas, haveria outro motivo para defender o postulado em questão que se relaciona com

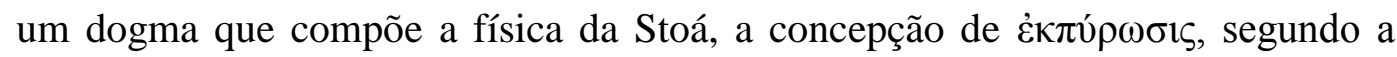
qual o cosmos inteiro periodicamente se dissolveria em fogo. Assim, o cosmos se expandiria e retrairia em um processo cíclico da seguinte forma:

a) Primeiramente, a partir da divisão do corpóreo em dois princípios originários ( $\alpha \rho \chi \alpha i$ ), um ativo e outro passivo, há a ação do princípio ativo divino (que é um pneuma ígneo) sobre o a matéria passiva.

b) Após esse instante criativo inicial, a formação do cosmos estaria completa. Nesse momento é muito difícil perspicazmente discernir o que é ativo e o que é passivo, tendo em vista que todos os corpóreos agem e sofrem ações uns dos outros simultaneamente. Contudo, não obstante a intensa sobreposição causal que há entre todos os elementos corpóreos, é possível detectar as sutis correntes causais, mas somente se compreenderse a mente de Zeus, que ordena a totalidade dos corpóreos, que é o cosmos, que é o próprio deus.

c) Apesar da aparente estabilidade cósmica, Zeus estaria passando da forma inicial de pneuma ígneo à forma de fogo puro e propiciando a consumição de todo o cosmos, do qual nada restaria exceto o próprio deus que se

${ }^{116}$ Compare com D.L. VII, 142-143

${ }^{117}$ Ver D.L. VII, 140.

${ }^{118}$ A defesa da posição ortodoxa estoica, segundo a qual há um cosmos finito circundado por um vazio infinito, proferida por Cleomedes aparece em seu Cael. 1. 1-5. A discussão entre os pitagóricos e os filósofos da Stoá acerca de questões cosmológicas aparece, de modo geral, em 
tornou fogo. Eis a necessidade cosmológica de postular o vazio: é o espaço incorpóreo infinito que o cosmos corpóreo ocupa e que o envolve mesmo quando de sua expansão.

d) O fogo criativo ( $\pi$ õ $\tau \varepsilon \chi v \vee \kappa o ́ v)$, que se tornou tudo o que há, é o mesmo que um animal cósmico sem corpo, é pura alma ${ }^{119}$. Por rarefação, o fogo viria a se tornar ar (princípio ativo) que engendraria a umidade da qual surgiriam da parte líquida a água, da parte espessa a terra e da parte sutil o fogo (todos, elementos passivos) ${ }^{120}$.

e) Novamente, teríamos um cosmos corpóreo divino que é pneuma ígneo e que, apesar da normalidade aparente, mais uma vez caminharia para a $\dot{\varepsilon} \kappa \pi u ́ \rho \omega \sigma \imath \varsigma^{121}$.

Tendo exposto os processos cíclicos de formação e deflagração cósmicas, resta-nos ressaltar que, mais do que conceber a eterna recorrência do cosmos como uma interminável série de ciclos, deve-se concebê-la como um único ciclo, mas que se repete interminavelmente. Desse modo, tudo o que compõe o cosmos em cada uma das suas repetidas criações é sempre o mesmo, porque o próprio cosmos é governado pela mente de Zeus, então tem a melhor organização possível, e há somente uma melhor organização possível: o cosmos atual, que é criado e destruído repetida e identicamente, propiciando uma eterna recorrência não só de si mesmo, mas também dos mesmos eventos.

Conforme já dito outrora, há uma relação direta entre a física e a ética da Stoá, antes, porém, de atermo-nos especificamente à parte ética, devemos

Simplício, os postulados de Arquitas em Phys. 467, 26-35, e os de Cleomedes em Cael. 284, 28$285,1$.

${ }^{119}$ Ver St. Rep. 1053 b.

${ }^{120}$ Ver D.L. VII 142.

${ }^{121}$ Há complicações evidentes quanto à cosmologia estoica, a primeira delas é temporal: como discernir temporalmente entre o fogo criativo e o pneuma ígneo, tendo em vista que se o fogo é criativo ele deveria ser o princípio ativo ao invés do pneuma ígneo, e assim aquele deveria, na criação, preceder este que, por sua vez, é habitualmente considerado como meramente um combustível não criativo (Ecl. 213,17-19)? E também o problema já apresentado da distinção entre o deus ativo e a matéria passiva. A outra complicação é espacial e necessita de um incremento conceitual, pois se há o real que inclui os corpóreos e os incorpóreos e também o existente que inclui somente os corpóreos, então deve haver uma totalidade de tudo o que existe (ö um conjunto menor do que o todo $(\pi \tilde{\alpha} \varsigma)$ que, por seu turno, inclui também o que não existe, mas é

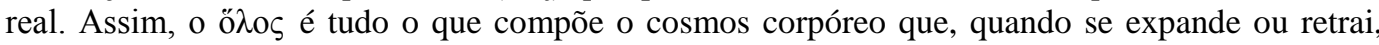
ocupa espaço dentro da esfera maior do tudo que, ao incluir os incorpóreos, inclui o vazio infinito que envolve o existente corpóreo finito. Ver Adv. Phy. I, 332. 
considerar alguns conceitos pertencentes à parte física, mas que demonstram quão interligadas essas duas partes estão, são eles: destino, providência e alma.

Assim, o cosmos é todo ele regido pela mente de Zeus, então há um rígido determinismo causal que é a própria providência divina. Os elos causais entre eventos propiciam uma inescapável ordem suscitada pelas suas conexões, é a isso que os estoicos chamam destino (

Que todas as coisas acontecem de acordo com o destino dizem Crisipo em sua obra Do Destino, Posidônio no segundo livro de sua obra Do Destino, e Zenão e Boêtos no primeiro livro da obra Do Destino. O destino é um encadeamento de causas daquilo que existe, ou a razão que dirige e governa o cosmos. (D.L. VII 149). ${ }^{122}$

O cosmos estoico, concebido como um mecanismo no qual cada evento segue a um evento predecessor e imediatamente cria eventos posteriores, não admite acaso ou mudanças ${ }^{123}$, tudo o que parece acontecer por escolha ou sorte, por exemplo, fora determinado anteriormente por uma causa qualquer que porventura fugira à nossa atenção. Deus, a mente que administra tudo (e o corpo que tudo é), providentíssimo e sapientíssimo, como um titereiro, move todas as cadeias causais.

\footnotetext{
${ }^{122}$ Na sequiência, Diógenes Laércio apresenta o argumento estoico favorável à adivinhação, tendo em vista que se tudo faz parte de uma corrente causal, então é possível prever os acontecimentos futuros.

${ }^{123} \mathrm{E}$ também não admite milagres ou livre arbítrio, entrando assim em conflito com as doutrinas cristãs. Ademais, se o cosmos é regido por uma corrente causal inextrincável, e deus faz parte do próprio cosmos, então deus está submetido à causalidade? Assim, Antigos admiradores cristãos do estoicismo propuseram respostas para esses problemas, Calcídio foi o primeiro neoplatônico cristão que parece ter se dado conta do equívoco de supor que deus estava submetido à corrente causal, por que sua providência é a própria corrente (in Tim. 144). Outros autores, como Plutarco, identificam deus, ao invés da sua providência, com a ordem necessária das causas (St. Rep. 1050ab). Quanto ao destino, críticas a essa noção já eram feitas mesmo no tempo da antiga Stoá, propiciando tréplicas criadas pelos grandes escolarcas, ambas nos são relatadas por Cícero (De Fat. 28-30). O argumento mais notável contra o destino chama-se "argumento do preguiço" e, em suma, alega que se tudo é regido por uma teia causal inextrincável que é a providência divina, então não importa como ajamos, sempre chegaremos aos mesmos fins, a própria ação seria desnecessária, de modo que se doentes, chamando o médico ou não, poderemos ser curados caso seja nosso destino. A tréplica a esse argumento foi lançada pelo próprio Crisipo, que recorre a uma distinção entre destinos simples e conjugados, segundo a qual o primeiro tipo de destino é fruto direto da essência de uma coisa (e assim uma coisa mortal morrerá, porque isso é inerente a ela) e o segundo tipo, por sua vez, é mais complexo e envolve outra distinção, dessa vez entre causas internas e externas. Desse modo, ao dizermos que "Sócrates morrerá" estamos falando algo que certamente ocorrerá dado que Sócrates é mortal, a morte é o destino simples de tudo o que é mortal por ser causada por causas internas inerentes aos seres mortais. Mas ao dizermos que "Sócrates morrerá hoje à tarde", estamos somando o destino simples, inerente à sua mortalidade, a uma série de condições propiciadas por diversas causas externas conjugadas, não é, então, fato determinado quando Sócrates morrerá, apesar de certamente morrer em algum dia. Com essa artimanha argumentativa, Crisipo evitou o "argumento do preguiçoso" alegando que somente o destino
} 
Finalmente, considerando que o cosmos estoico é animado e, desse modo, uma espécie de ser vivo, e também que a sua alma é caracterizada como pneuma, tem-se como consequência que as almas dos outros seres vivos menores que fazem parte do conjunto cosmos são, da mesma forma, pneuma e fragmentos do pneuma que é a alma do deus/cosmos. Assim, também no aspecto anímico (além do aspecto causal), as vidas de cada um dos seres que compõem o universo são interligadas, pois se originam em uma mesma vida maior, a do próprio deus.

Lembrando uma parte mais anterior na nossa argumentação em que mencionamos os diferentes graus de tensão ( $\tau o ́ v o r)$ do pneuma ígneo que tudo permeia quando o cosmos deixa de ser fogo criativo, há dele três níveis de tensão: coesão, natureza ou crescimento e alma. A coesão sustenta os agregados que formam os objetos inanimados. A natureza ou crescimento é responsável pela vida vegetativa das plantas. A alma é o poder da vida consciente presente em animais. A esses três deve-se ainda acrescentar um quarto grau de tensão do pneuma, a alma racional ( poder racional de julgar que, por sua vez, é o que propicia uma interposição entre a recepção passiva de impressões e a ação consciente. Assim, os seres humanos possuem os quatro graus de tóvor do pneuma: a coesão, dado que são objetos que compõem o cosmos; a natureza, que é o princípio que nos faz crescer e que se faz presente desde quando somos fetos; a alma, que nos torna capazes das percepções sensíveis, do movimento e da reprodução; e a alma racional, que nos dá a capacidade de julgar.

Em suma, para os estoicos, os seres humanos têm as duas manifestações da alma, ao passo que os outros seres possuem tão-somente a parte estritamente sensível. Além disso, essa alma humana "dupla", comparada a um polvo (Plac. 4.21.2) possui oito divisões (D.L. VII 157): os cinco sentidos, as faculdades da

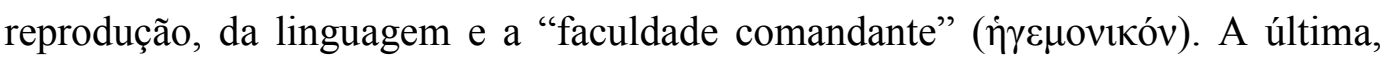
por seu turno, pode ser dividida em três outras faculdades: impressão, impulso e assentimento, das quais as duas primeiras são compartilhadas com os animais irracionais, a faculdade de assentimento, contudo, só existe nos seres humanos e é 
o que nos define como racionais, diferenciando-nos dos outros seres, sendo o âmago mesmo do nosso ser ${ }^{124}$.

Houve diversas divergências médicas entre os filósofos da Stoá quanto à

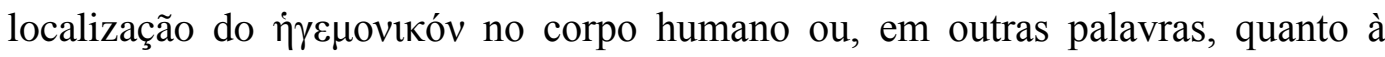
localização em nós do órgão corpóreo sede da faculdade do assentimento. De acordo com Galeno ${ }^{125}$, Zenão e Cleanto localizavam-no no cérebro, ao passo que Crisipo o localizou no coração, seguindo os dois primeiros, Erasistratos também

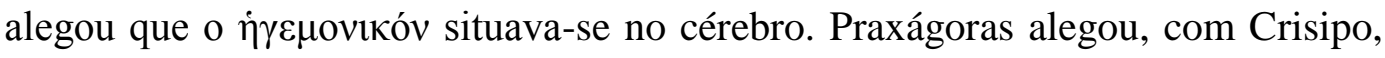

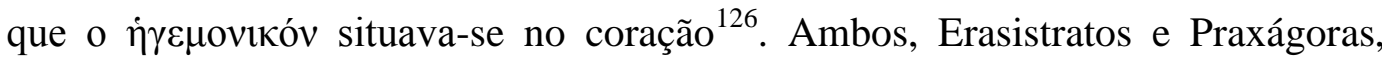
desenvolveram teorias que asseriram que havia uma rede que espalhava os

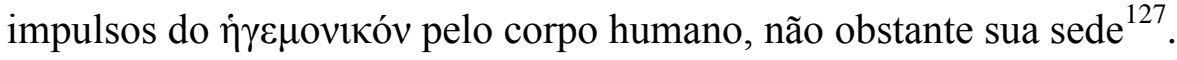

\subsection{A ética estoica}

Tendo apresentado as principais teses da física da Stoá, e considerando que a ética fundamenta-se toda na física, devemos agora tratar da concepção estoica da moral.

Mas não podemos seguir sem considerar um aspecto crucial da discussão.

À primeira vista podem parecer estranhas todas as disputas entre as escolas filosóficas do período Helenístico, pode-se imaginar, por exemplo, como modo de escapar delas, optar pelo ecletismo, adotando seletivamente ora uma posição derivada de uma escola, ora outra posição derivada de outra escola, de fato, foi o que fizeram alguns filósofos. Contudo, em sua maior parte, não era o que faziam, os filósofos apegavam-se à totalidade dos dogmas e teses das escolas que, ademais, disputavam a hegemonia como a única nova $\pi \alpha 1 \delta \varepsilon i ́ \alpha$, substituta daquela do mundo clássico, em ruínas.

Dessa forma, como argumentamos alhures ${ }^{128}$, propomos que se pensem os princípios morais das escolas segundo o conceito kantiano de 'máxima', de

\footnotetext{
${ }^{124}$ Ressalto que, como veremos mais adiante, ao rejeitar a faculdade do assentimento, propondo

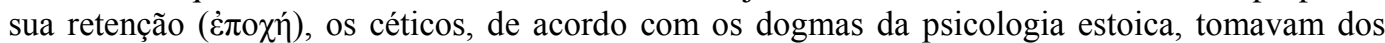
homens sua própria humanidade, tornado a vida humana impossível de ser vivida.

${ }^{125}$ Ver PHP 1.6.12.

${ }^{126}$ Ver PHP 1.6-7.

${ }^{127}$ Ver De Piet. 9,9-13.

${ }^{128}$ Ver: 'BRITO, R. P. O estoicismo e suas máximas: Epicteto. In: Breviário de Filosofia Pública, $n^{\circ} 78,11 / 2012$ ', lá enveredamos por uma distinção entre apotegmas e máximas, aqui, por outro lado, evitaremos tal distinção para suscitar uma relação etimologicamente mais correta entre apotegmas e $\dot{\alpha} \pi \circ \varphi \theta \dot{\varepsilon} \gamma \mu \alpha \tau \alpha$, ambos tratados genericamente como máximas.
} 
acordo com a interpretação de $\operatorname{Bittner}^{129}$ (citado abaixo), que nos aponta que há em Kant basicamente três definições expressas de máximas:

1-“Máxima é o princípio subjetivo do querer; o princípio objetivo (isto é, aquele que serviria também subjetivamente de princípio prático a todos os seres racionais, se a razão tivesse completo domínio sobre a faculdade de apetição) é a lei prática." (Kant, 'Fundamentação da Metafísica dos Costumes' 400)

2-"Máxima é o princípio subjetivo do agir, e tem de ser distinguida do princípio objetivo, a saber, da lei prática. Aquela contém a regra prática determinada pela razão de acordo com as condições do sujeito (muitas vezes de acordo com a sua ignorância ou suas inclinações), e é, portanto, o princípio de acordo com o qual o sujeito age; a lei, porém, é o princípio objetivo, válido para todo ser racional, princípio segundo o qual ele deve agir, isto é, um imperativo." (GSM 421)

3-"Proposições fundamentais práticas são proposições que contêm uma determinação universal da vontade, [determinação] que tem sob si diversas regras práticas. Essas proposições são subjetivas, ou máximas, se a condição for considerada pelo sujeito como válida somente para a vontade dele; mas elas são objetivas, ou leis práticas, se a condição for conhecida como objetiva, isto é, como válida para a vontade de todo ente racional." (Kant, 'Crítica da Razão Prática' 35).

Assim, os apotegmas da filosofia da Stoá (do grego $\alpha \pi$ ó $\varphi \theta \varepsilon \gamma \mu \alpha$, no caso nominativo singular neutro, de plural: $\dot{\alpha} \pi \circ \varphi \theta \dot{\varepsilon} \gamma \mu \alpha \tau \alpha$, exortações ou sentenças), uma vez entendidos como máximas são (seguindo os critérios que definem uma máxima em sentido kantiano, segundo Bittner):

1- princípios ou proposições fundamentais que,

2- enquanto princípios, devem determinar o querer e o agir.

3- Determinam o querer e o agir em um âmbito estritamente subjetivo.

4- Deve-se não só querer agir de uma determinada maneira, mas, de fato, deve-se agir dessa maneira.

5- Por outro lado, apesar da subjetividade da máxima, ela deve poder ser generalizada, e a sua generalidade deve estar no fato de que elas devem orientar a vida do sujeito em sua totalidade.

6- Não obstante, os $\dot{\alpha} \pi \circ \varphi \theta \varepsilon ́ \gamma \mu \alpha \tau \alpha$ não poderão ser máximas se forem muito universais, porque poderiam incluir sob si diversos modos de vida distintos e contraditórios.

7- O corolário disso é que as máximas são alimentadas e alimentam a própria experiência de vida do sujeito.

129 'BITTNER, Rüdiger. Máximas. In: Studia Kantiana, n 5, novembro de 2003.' 
Ademais, viver verdadeiramente de acordo com suas máximas e submeter a compreensão de sua própria experiência de vida à luz dos $\alpha \operatorname{\pi } \operatorname{\varphi } \varphi \theta \dot{\varepsilon} \gamma \mu \alpha \tau \alpha$ adotados consciente e subjetivamente é ter caráter, por sua vez, "o derradeiro fundamento subjetivo da adoção das máximas" (Kant, 'A Religião dentro dos limites da simples razão', p. 25, p. 20), escolhido livremente, embora não se possa saber o motivo.

Então, o caráter do homem estoico (e também epicurista, acadêmico, cínico, peripatético, pitagórico...) é atestado pela observância irrestrita de $\dot{\alpha} \pi \circ \varphi \theta \dot{\varepsilon} \gamma \mu \alpha \tau \alpha$ que determinam sua vontade, em sentido prático, mas os $\dot{\alpha} \pi \circ \varphi \theta \dot{\varepsilon} \gamma \mu \alpha \tau \alpha$, além disso, devem poder ser generalizados, tornando-se nortes de toda a experiência de vida do sujeito, alimentando-a e excluindo os outros $\grave{\alpha} \pi \circ \varphi \theta \dot{\varepsilon} \gamma \mu \alpha \tau \alpha$ que contrariam essa própria experiência de vida. Eis a contundência das disputas em que "Homens de caráter (...) estavam perturbados pelas contradições nas coisas e hesitantes quanto a qual das alternativas deveriam aceitar" (P.H. I, 12), situação que se tornou alvo do satirista Luciano ${ }^{130}$, por exemplo.

Desse modo, um aspirante a estoico estudaria as três partes da filosofia e praticaria os exercícios típicos da escola que são desdobramentos de sua concepção de ética, com o objetivo de alcançar a felicidade, não obstante a adversidade das circunstâncias. Para tal, ele disporia de um conjunto de máximas morais que orbitam, por sua vez, em torno da concepção de natureza (

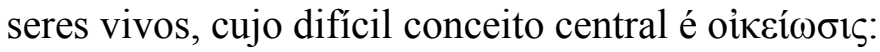

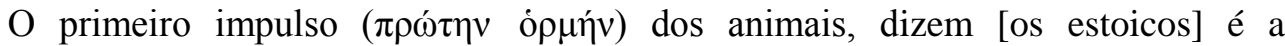
autopreservação, porque a natureza, no princípio, apropriou-se para si mesma

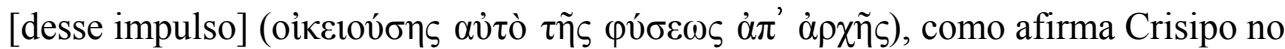
primeiro livro de seu Sobre os Fins, suas próprias palavras são: "A mais

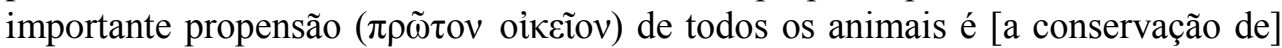
sua própria constituição e a consciência da mesma. (D.L. VII, 85). ${ }^{131}$

Para os estoicos, todos os animais, inclusive humanos, agem por impulso (ópứ). O primeiro deles é o de autopreservação, o mais importante e que engendra-nos o cuidado com a prole, a busca por alimentos e água, e também abrigo, por exemplo. Desse modo, devemos ao impulso de autopreservação a continuidade e o sucesso de nossas existências. Mas, se a autopreservação é nosso

${ }^{130}$ Ver: Luc.Herm. e Vit. Auct. 
impulso mais básico (o mais próximo de um sentimento inato que os estoicos chegaram a conceber), então, nossas escolhas e ações mais primitivas são talhadas por ele, de tal forma que determina que escolhamos o que é capaz de satisfazer melhor nossas necessidades vitais, sempre. Haveria, consequentemente, uma regra instintiva para a ação correta (aquela que não depõe contra a própria vida, ou contra a vida de outrem intimamente ligada a nossa, como a prole) que é, por sua vez, ditada pela nossa própria natureza animal: a autopreservação.

Ora, se (1) bom é aquilo que preserva nossa vida animal e mal é aquilo que a prejudica - e, assim como os outros animais, "sabemos" disso instintivamente —, além disso, se esse é (2) um primeiro substrato sobre o qual os humanos e os demais animais atribuem valores às coisas, então, (3) para os

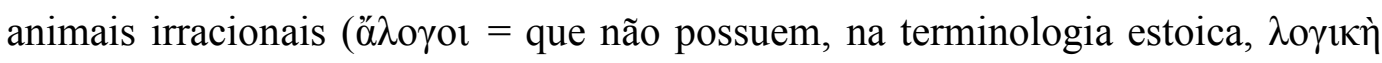
$\psi v \chi \eta ́$, mas possuem $\psi v \chi \eta ́)$, bom é beber quando se tem sede e comer quando se tem fome, por outro lado, para os humanos, embora beber e comer também sejam bons porque satisfazem nossa natureza estritamente animal, temos também uma natureza humana, racional, e assim, (4) devemos nos preservar não só como seres físicos, mas também como seres predominantemente racionais, tal que, em circunstâncias em que a morte do corpo é preferível à vida irracional, ou que contraria as máximas racional e livremente escolhidas, deve-se optar pela morte do corpo, para que sobreviva o $\lambda o ́ \gamma o \varsigma$. Para os estoicos, não há, portanto, contradição entre o princípio de autopreservação e o suicídio, de modo que homens condenados que se erguem diante de tiranos, mesmo causando a perda de sua própria vida (Diss. 1.2), "não se salva[m] por quaisquer meios vergonhosos; mas morrendo, e não fugindo" (Diss. 4.1.165), como fizeram Catão, que se opunha fortemente a Júlio César e suicidou-se após a vitória dele na batalha de Tapso, em 46 a.C. ${ }^{132}$, e Sêneca que, assim como sua mulher (que sobreviveu), aceitou resignadamente o suicídio imposto sem julgamento por Nero, e cortou os pulsos em 65 d.C. numa morte inspirada pela de Sócrates ${ }^{133}$.

Para Catão e Sêneca, a própria existência do corpo era indiferente quando comparada a excelência que, de fato, é a única coisa desejável por si mesma,

\footnotetext{
${ }^{131}$ Compare com: Ep. 121.6-15; St. Rep. 1038B; De Fin. 3.62-8.

${ }^{132}$ Ver Vit. Par., Vida de Catão, o jovem.

${ }^{133}$ E talvez também Zenão de Cítio (D.L. VII, 28) e Cleanto de Assos (D.L. VII, 176) tenham dado fim às suas próprias vidas, igualmente inspirados por Sócrates.
} 
assim como o vício é a única coisa evitável por si mesma. Dessa forma, podemos divisar as coisas que existem em três grupos quanto ao seu apelo moral:

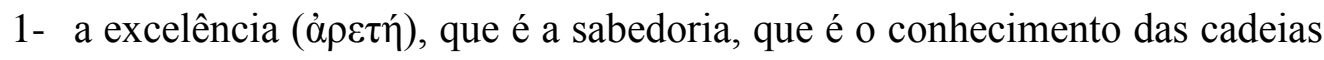

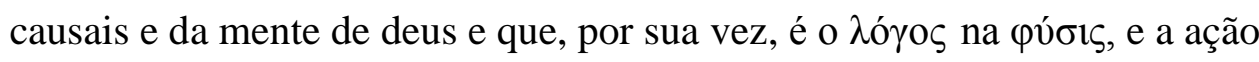
conforme esse $\lambda$ ó $\gamma$ o é a ação conforme a vontade de deus.

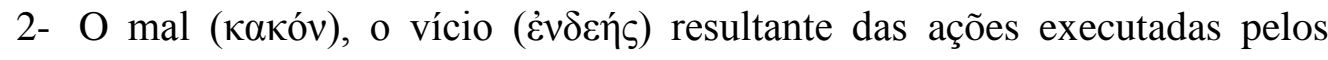

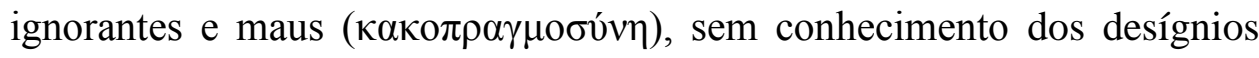
divinos/naturais.

3- Os indiferentes ( $\dot{\alpha} \delta$ í́ $\varphi \rho \rho o \imath)$, bens e males corporais externos que, como relacionamentos sociais, alimentos, água, apesar de poderem facilitar o alcance da virtude, podem igualmente facilitar o vício, por isso são indiferentes, têm potencial para o bem e para o mal, indistintamente e, se não são desejáveis por si sós, também não são evitáveis por si sós.

Uma vez possuindo essa distinção terminológica, podemos compreender, voltando ao exemplo do tirano, como se dá a ação do homem estoico. O tirano obriga que o sujeito cometa um ato vil em troca da continuidade de sua vida; o sujeito percebe que a execução do ato o leva ao vício e contraria as máximas que escolheu voluntaria e racionalmente, e é justamente a capacidade de escolher racionalmente (através do órgão exclusivamente humano do i் $\gamma \varepsilon \mu o v$ เóv) que o define como humano; e, como humano e possuidor de $\lambda \sigma \gamma$ que possui o instinto da autopreservação, mas que deve preservar, como ser racional, sua própria existência enquanto racionalmente capaz de escolher; assim, considerando que a excelência é a sabedoria, o uso pleno da razão, diante da impossibilidade de agir conforme os $\dot{\alpha} \pi \circ \varphi \theta \dot{\varepsilon} \gamma \mu \alpha \tau \alpha$ racionalmente escolhidos e então de alcançar a excelência, ele opta pela morte, porque a vida física é indiferente.

Esse posicionamento é atribuído ao próprio Zenão de Cítio e deve ser entendido como um modo de conciliar a concepção cínica de ảpetí, que

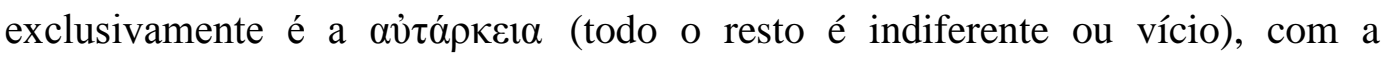
concepção platônica, do acadêmico Pólemon, que atribuía valor a bens corporais 
externos $^{134}$. Assim, para Zenão, mesmo considerando como os cínicos que somente a excelência é desejável e o vício evitável, por outro lado, ele atribuía valor aos bens corporais externos que poderiam facilitar circunstancialmente o alcance da excelência, embora enfatizasse que eles não eram desejáveis por si mesmos. Talvez essa flexibilização da abordagem cínica original tenha surgido após as críticas severas que despontaram contra os cães, possivelmente Zenão tenha aderido plenamente às máximas cínicas em sua juventude, quando escreveu sua 'República', e justamente por levar a sério e refletir sobre os limites do cinismo optou por uma solução menos controversa ${ }^{135}$, de toda forma, sua teoria suavizada, que admite a importância dos bens corporais externos (embora recuse que sejam $\tau \varepsilon \dot{\lambda} \lambda \varsigma_{\varsigma}$ ), foi ainda mais amenizada por estoicos posteriores ${ }^{136}$. Por outro lado, a distinção zenoniana (entre indiferentes, virtude e vício) ganhou, com Epicteto, a importante e sutil diferenciação conceitual e prática entre o que

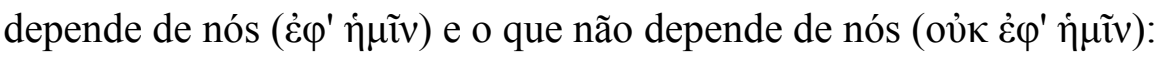

\begin{abstract}
Algumas coisas dependem de nós ( $\left(\dot{\varepsilon} \varphi^{\prime} \dot{\eta} \mu \tilde{u} v\right)$, enquanto outras não dependem de

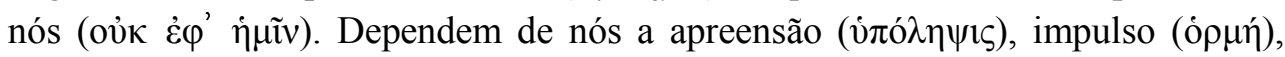

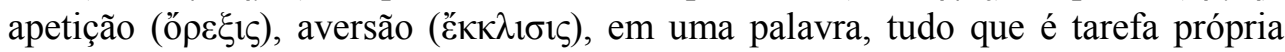
nossa; não dependem de nós nosso corpo, nossa propriedade, reputação, trabalho e, em uma palavra, tudo que não é tarefa própria nossa. Além disso, as coisas que

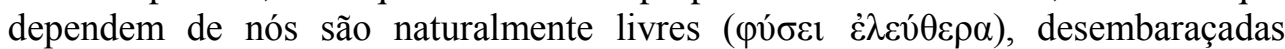

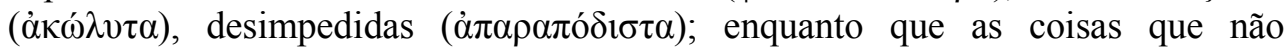
dependem de nós são fracas, servis, sujeitas e impedidas e não nos concernem. (Ench. 1. 1-2).
\end{abstract}

Em Epicteto, todos os indiferentes, não importa quão potentes sejam para facilitar o alcance da virtude, recaem na categoria daquilo que não depende de nós, não devemos, então, nos preocupar com eles, somente a excelência deve ser alvo de nossa atenção, somente ela está submetida ao nosso poder de escolha ( $\pi \rho 0 \alpha i ́ p \varepsilon \sigma 1 \varsigma)$. Dessa forma, se viver de modo a obter a excelência é algo que deve ser escolhido, então, é justamente essa a escolha louvável, que deve ser

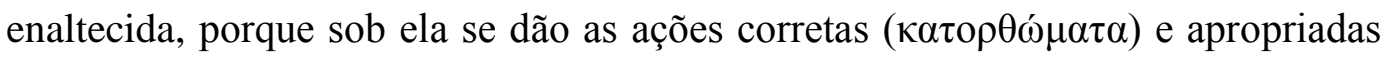

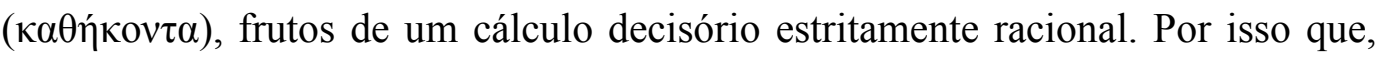

\footnotetext{
${ }^{134}$ Compare com Nic. Eth. 9.9. Como havíamos dito anteriormente, não endossamos a hipótese de que Zenão tivesse sido influenciado pelo peripatos, mas também não a rejeitamos, somos coagidos a suspender o juízo sobre isso, dada a aporia entre os pesquisadores e historiadores das ideias acerca desse assunto.

${ }^{135}$ Ver: Acad. pr. 36-37.

${ }^{136}$ Ver: De Fin. 3.10, 3.41.
} 
para os estoicos, as ações corretas que advém da opinião não têm valor, porque apesar de corretas são frutos da ignorância, o mais vil dos vícios e, se quanto ao resultado diferem do mal, não diferem quanto ao princípio.

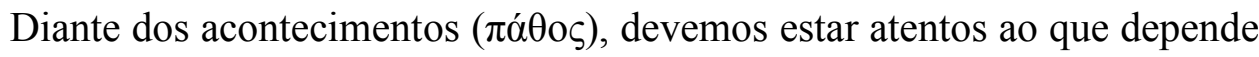

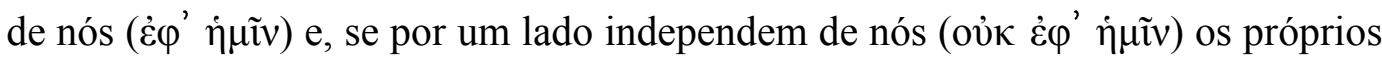
acontecimentos, por outro lado, está sob nosso poder, através da parte comandante

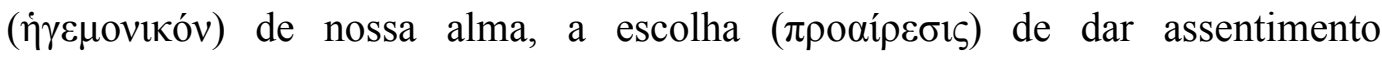

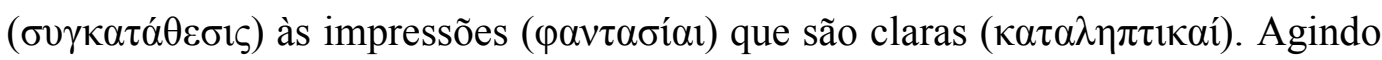
de acordo com essas impressões claras, tomamos ações totalmente racionais e

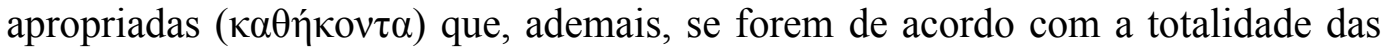
máximas e com a concepção estoica de virtude, são ações perfeitas

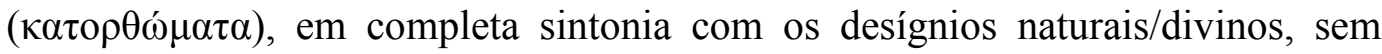
inquietações. Nesse caso, o homem se torna virtuoso, excelente e vive feliz.

Mas, se para agir indefectivelmente é preciso assentir às impressões corretas, é preciso também saber quais são essas impressões, entramos então no domínio da teoria estoica do conhecimento.

\subsection{A teoria estoica do conhecimento}

Comecemos com Aulo Gélio, em uma passagem por si só eloquente:

Navegávamos de Cassiopa a Brundisium pelo mar Jônico, violento, vasto e tempestuoso. Durante quase a totalidade da noite que se seguiu ao nosso primeiro dia, soprou um feroz vento lateral, que encheu nosso navio com água. Então, logo após, enquanto ainda nos lamentávamos e trabalhávamos duro nas bombas, o dia finalmente raiou. Mas não havia menos perigo e diminuição da violência do vento; pelo contrário, mais frequentes turbilhões, um céu negro, massas de nuvens, e um tipo assustador de formas de nuvens, que eles chamam de Tífon, pareciam pairar sobre nós e ameaçavam-nos, prontas para dominar o navio.

Em nossa companhia estava um eminente filósofo da seita estoica que conheci outrora em Atenas como um homem de pouca importância, mantendo o jovem que era seu pupilo sob um ótimo controle. Em meio a grandes perigos daqueles tempos e aquele tumulto do mar e do céu, olhei para ele, desejoso de saber em que estado mental ele se encontrava e se estava sem medo e corajoso. E então vi o homem amedrontado e bastante pálido, mas sem de fato proferir quaisquer lamentações, como todo o resto fazia, e nem quaisquer clamores, mas em sua perda de cor e expressão distraída, não diferindo muito dos outros. Mas, quando o céu clareou, o mar acalmou-se, e o calor do perigo esfriou-se, então o estoico aproximou-se de um grego rico da Ásia, um homem de aparência elegante, de acordo com o que vimos, e com uma abundância de bagagem e muitos serviçais, enquanto ele próprio demonstrou sinais de uma disposição e personalidade luxuriosas. Esse homem, em 
um tom brincalhão, disse: "O que isso significa senhor filósofo, quando estávamos em perigo, você ficou amedrontado e pálido, enquanto que eu nem temi e nem mudei de cor?" E o filósofo, após hesitar por um momento acerca da pertinência de respondê-lo, disse: "Se em uma terrível tempestade eu demonstro pouco medo, você não é capaz de dizer a razão para tal. Mas, se lhe agradar, o famoso Aristipo, o pupilo de Sócrates, responderá por mim. [Ele], ao ser questionado em uma ocasião semelhante por um homem muito parecido com você, porque temera, embora fosse um filósofo, enquanto que seu questionador, pelo contrário, não teve medo, respondeu que não tinha os mesmos motivos, pois seu questionador não precisava estar ansioso quanto a vida de um almofadinha inútil, mas ele próprio temia pela vida de Aristipo."

Com essas palavras então, o estoico livrou-se do rico asiático. Mas, mais tarde, quando nos aproximávamos de Brundisium e o mar e o céu estavam calmos, perguntei-lhe qual era a razão de seu medo, que ele recusara-se a revelar ao homem que impropriamente se the dirigiu. E ele calma e cortesmente respondeu: "Uma vez que deseja saber, ouça o que nossos antepassados, os fundadores da seita estoica, pensavam sobre aquele breve, mas inevitável e natural medo, ou mais", disse ele, "leia sobre isso, pois se ler, será mais apto a crer e lembrará melhor." Assim, diante de meus olhos, tirou de sua pequena bolsa o quinto livro dos Discursos do filósofo Epicteto, que, conforme organizado por Arriano, sem dúvida concorda com os escritos de Zenão e Crisipo.

Nesse livro, li esta declaração, que na verdade estava escrita em grego: "As visões mentais, que os filósofos chamam de $\varphi \alpha v \tau \alpha \sigma i ́ \alpha$ ou 'impressões', pelas quais a mente do homem, à primeira aparição do objeto, é impelida à percepção do objeto, não são nem voluntárias e nem controladas pela vontade, mas, através de certo poder que possuem, forçam aos homens seu reconhecimento; mas, as expressões de assentimento, que chamam de $\sigma 0 \gamma \kappa \alpha \tau \alpha \theta \varepsilon \dot{\sigma} \sigma \varepsilon 1 \zeta$, através das quais essas visões são reconhecidas, são voluntárias e submetidas à vontade do homem. Assim, quando algum som terrível, seja do céu, seja de um prédio que cai, ou o anúncio repentino de algum perigo, ou algo do tipo ocorre, mesmo a mente do sábio deve ser necessariamente afetada, deve contrair-se e alarmar-se, não por uma ideia preconcebida de qualquer perigo, mas por certo ataque rápido que oblitera o poder da mente e da razão. De fato, contudo, o sábio não aprova tais impressões, ou seja, tais visões mentais assustadoras, mas ele as rejeita e despreza, nem vê nelas algo que deva excitar medo. E dizem que é esta a diferença entre a mente do tolo e a do sábio, o tolo pensa que essas visões realmente são tão assustadoras e amedrontadoras quanto parecem, quando do primeiro impacto delas sobre sua mente, e, por seu assentimento, ele aprova tais ideias como se fossem realmente para ser temidas, e as confirma; pois $\pi \rho 0 \sigma \varepsilon \pi \imath \delta$ óá $\zeta \varepsilon 1$ é a palavra que os estoicos usam nos seus discursos sobre o assunto. Mas o sábio, após ser afetado por um curto e fraco tempo em sua cor e expressão, 'não assente', mas refreia a firmeza e força da opinião que sempre teve sobre as visões desse tipo, ou seja, não há para o sábio algo a ser temido, a excitação do terror advém da aparição falsa (fronte falsa) e dos alarme vãos."

Estas são as opiniões e asserções de Epicteto, o filósofo, de acordo com as crenças dos estoicos que li no livro que disse, e pensei que deveriam ser relatadas pela razão que, quando coisas desse tipo que mencionei ocorrem, não devemos pensar que temer brevemente, como se deu, e ficar branco é a marca de um homem tolo e fraco, mas nesse breve impulso natural, entregamo-nos à fraqueza humana porque cremos que tais coisas são o que vemos. (Noct. Att. 19.1, 1-20).

Conforme já visto, o objetivo da filosofia estoica é ético: a excelência, que é a sabedoria, que traz serenidade ou quietude ao sábio. Mas sábios estoicos são 
infalíveis porque estão seguros quanto ao seu conhecimento da estrutura providencial do mundo (física), que é o destino e a vontade de Zeus ${ }^{137}$, eles sabiamente ordenam a vida de acordo com essa vontade e vivem conforme a natureza, isto lhes garante serenidade ${ }^{138}$. Mas, para ser sábio é preciso estar municiado de uma epistemologia forte que indique com segurança a verdade,

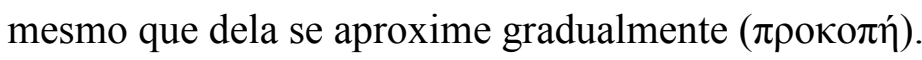

Por sua vez, como podemos identificar na citação de Aulo Gélio, a mola

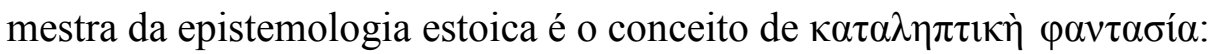

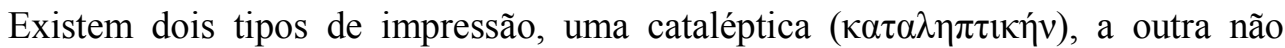

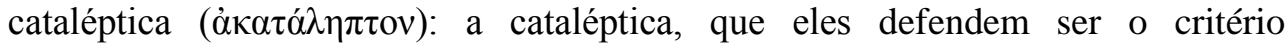
(крıтท́рıv) para os fatos, é a que vem de algo existente e que está de acordo com a própria coisa existente, tendo esta sido estampada e impressa; já a não cataléptica, ou vem de algo não existente ou, então, se vem de algo existente, não está de acordo com a coisa existente, e não é clara, nem distinta ${ }^{139}$. (D.L. VII, 46).

Convém ressaltar, antes de prosseguirmos, que mesmo que a noção de

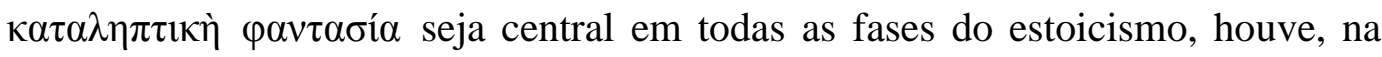
fase inicial, uma querela em torno dela. Para Zenão, as impressões catalépticas eram impressas na alma. Com isso concordou seu discípulo, Cleanto de Assos. Contudo, Crisipo via contradições na ideia de que as impressões catalépticas eram impressões na alma porque para os estoicos a alma era corpórea e, assim sendo, não seria possível imprimir algo nela inúmeras vezes, por que se se imprimisse nela muitas vezes as impressões primeiras ficariam distorcidas e não seria possível preservá-las, não haveria memória e as habilidades, uma vez que as $\tau \varepsilon ́ \chi v \alpha 1$, são entendidas pelos estoicos como um "sistema de impressões exercidas em conjunto" ( $A d v . \log$. I, 109). E, por sua vez, também não haveria experiência ( $\left.\dot{\varepsilon} \mu \pi \varepsilon \imath \operatorname{lí}^{\alpha}\right)$.

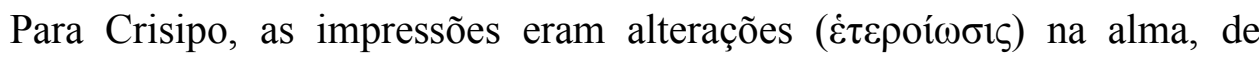
modo que haveria uma forma primordial da alma que não se conservaria porque desde o nascimento estaríamos suscetíveis a impressões que, cada uma delas,

\footnotetext{
${ }^{137}$ Ver: D.L. VII, 135; St. Rep. 1049f.

${ }^{138}$ Ver: D.L. VII, 87; De Fin. III 31, IV 14-15.

${ }^{139}$ Note-se a vinculação aqui da clareza e distinção como critério de verdade, compare com Descartes.
} 
mudaria a forma da alma, o acúmulo de mudanças justificaria o acúmulo de impressões e, portanto, a memória e as habilidades ${ }^{140}$.

À parte as querelas e pequenas discrepâncias, há que se notar que para os estoicos (ao contrário dos epicuristas) as impressões não são todas verdadeiras e que as verdadeiras devem obedecer as seguintes condições (segundo D.L. VII, 46):
a) devem derivar de objetos existentes;
b) devem representar acuradamente esses objetos;
c) devem estar estampados nos órgãos sensoriais.

Apesar do papel primordial das impressões sensíveis, o que justifica a ideia de que o estoicismo seja considerado um sistema empirista, deve-se ressaltar que não há só impressões sensíveis, mas também intelectuais, de modo que as impressões sensíveis vêm primeiro (são concepções mais anteriores $=\pi \rho 0 \lambda \eta \dot{\psi} \psi \varepsilon 1 \varsigma$ ) e ocorrem sem esforço consciente e naturalmente (e, se verdadeiras ou catalépticas, ou seja, em consonância com a natureza, permitem estruturar o conhecimento da própria mente de Zeus e a obediência a seus desígnios, embora não sejam o conhecimento em si). Contudo, em um segundo momento ocorrem impressões que são originadas no cultivo da mente (voũc) e na atenção. Essas

\footnotetext{
${ }^{140}$ Ver: $A d v$. Log. I, 230, onde, conforme salientado por Aldo Dinucci, na ocasião da Defesa da presente Tese, "há ainda uma distinção entre a concepção de Cleanto e a de Crisipo acerca de

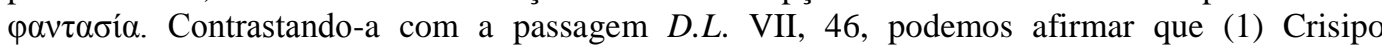
desenvolveu a concepção de Cleanto, como o pensa Annas ('Hellenistic Philosophy of Mind. Berkeley: University of California Press, 1991', p. 72-75), no que é seguida por comentadores como Deborah Modrak ('Stoics, Epicureans and Mental Content. In: Apeiron 26(2), 1993', p. 99) e Long e Sedley ('Hellenistic Philosophers, vol I. Cambridge: Cambridge University Press, 1987', p. 239); (2) que, embora tanto Cleanto quanto Crisipo considerem a $\varphi \alpha v \tau \alpha \sigma i ́ \alpha$ algo físico, eles divergem ao explicar essa mudança física como não somente imagética, posição que é sustentada por Lesses ('Content, Cause and Stoic Impressions. In: Phronesis vol. XLIII/1, 1998', p. 6), para quem Crisipo parece criticar Cleanto por aceitar uma concepção ingênua de representação mental segundo a qual impressões perceptivas são cópias de qualidades que os objetos representados possuem; (3) que, como observa Annas (op. cit., p. 74-75), está implicado nas observações de Crisipo que as $\varphi \alpha v \tau \alpha \sigma i ́ \alpha$ são proposicionais ou articuláveis em forma linguística. Pelo dito,

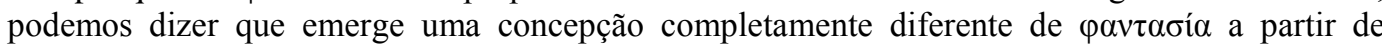
Crisipo. A $\varphi \alpha v \tau \alpha \sigma i ́ \alpha$, então, não é mais verdadeira ou falsa por si em sentido primário e não possui qualquer similaridade com aquilo que a causou. $\mathrm{O}$ que pode ser verdadeiro ou falso em sentido

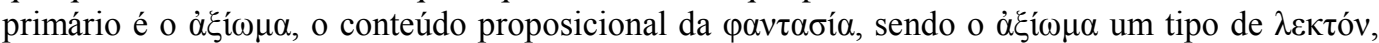
algo que pode ou não ser expresso em palavras, mas que é, de toda forma, o fundamento da

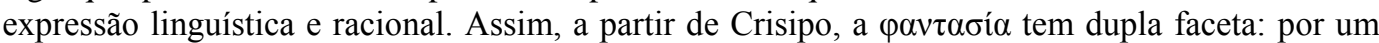
lado, o conteúdo perceptivo captado pelos sentidos; por outro, o conteúdo axiomático que é

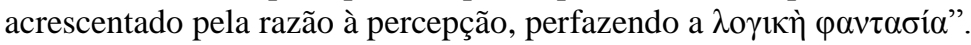


impressões intelectuais são conceitos ( $\dot{\varepsilon} v v o \eta ́ \mu \alpha \tau \alpha)$, que são imagens na mente de um animal racional e criam o entendimento científico ( $\left.\dot{\varepsilon} \pi \iota \tau \eta^{\mu} \mu \eta^{141}\right)$.

Podemos, então, propor o seguinte esquema para a teoria estoica do conhecimento:

$1^{\circ}$ - Há impressões que nos afetam e diante das quais somos passivos:

a) algumas são não catalépticas (não obedecem aos critérios de clareza e distinção) e não são seguras;

b) outras são catalépticas e são seguras, obedecem aos critérios de clareza e distinção e se dão naturalmente e em conformidade com a natureza.

$2^{\circ}$ - Mas, devemos escolher assentir àquelas impressões catalépticas, evitando as não catalépticas.

$3^{\circ}$ - $\mathrm{O}$ acúmulo de impressões catalépticas, utilizado em conjunto, gera as diferentes habilidades. Por exemplo: a marcenaria é uma habilidade que advém do uso em conjunto de toda uma gama de impressões.

$4^{\circ}$ - Esse mesmo acúmulo gera a memória que nos permite adquirir experiências.

$5^{\circ}$ - As experiências memorizadas e as próprias memórias causadas pelas impressões se tornam objetos de reflexão mental, criando impressões intelectuais (conceitos) $)^{142}$.

$6^{\circ}$ - A articulação dos conceitos através de mecanismos discursivos e lógicos possibilita o entendimento científico.

Não podemos prosseguir sem mencionar que, além do conhecimento e da ignorância, há a opinião, que tanto pode ser errada e assemelhar-se à ignorância, quanto ser correta e assemelhar-se ao conhecimento. Contudo, a ação fundamentada na ignorância deve ser condenada e, da mesma forma, a ação fundamentada na opinião incorreta, porque agir de acordo com opiniões incorretas é uma ação típica dos ignorantes. Mas as ações que transcorrem de acordo com as opiniões corretas, apesar de se assemelharem ao conhecimento, também são

\footnotetext{
${ }^{141}$ Ver: Plac. IV 11.1-6; Acad. pr. 41; Acad. pos. 20-22, 30-31; Com. Not. 47, 1084f-1085a .

142 Há ainda várias distinções conceituais acerca do modo como, através da absorção de impressões, se criam diferentes impressões mentais: "das coisas que concebemos, algumas são concebidas por contraste, algumas por similaridade, algumas ainda por analogia, algumas por transposição, algumas por composição e algumas por oposição" ( $A d v$. Log. II, 58-60). E: "ademais, algumas coisas são concebidas por transição, como significados e o lugar; bom e mau são concebidos naturalmente; e, ainda, algumas coisas por privação, como os aleijados" (D.L. VII, 53).
} 
originadas na ignorância porque, não obstante suscitarem ações corretas, não se originam no conhecimento, e toda ação que não é executada de acordo com o conhecimento é executada de acordo com a ignorância. Além disso, somente pode ser louvável a ação que é sabidamente correta, porque houve um cálculo decisório. São reprováveis, por outro lado, todas as ações incorretas, porque houve um cálculo decisório errôneo, e as ações corretas ou incorretas originadas em opiniões, porque não houve cálculo decisório.

Resta-nos ainda saber como agir então diante de impressões não catalépticas, sobre as quais não há clareza e distinção. A resposta é dada por Arcesilao em um debate entre ele e o próprio Zenão ${ }^{143}$ : se deve suspender o juízo, adsensionis retentio, conceitos respectivamente iguais aos gregos $\sigma 0 \gamma \kappa \alpha \tau \alpha ́ \theta \varepsilon \sigma \iota \varsigma \mathrm{e}$ $\dot{\varepsilon} \pi \circ \chi \eta ́$, na terminologia de Cícero (ver: Luc.59, 6), que será nosso principal guia daqui em diante.

\subsection{Arcesilao $X$ estoicos}

Como vimos acima, a adesão às $\kappa \alpha \tau \alpha \lambda \eta \pi \tau \iota \kappa \alpha i ̀ ~ \varphi \alpha v \tau \alpha \sigma i ́ \alpha \iota$ é o critério estoico da verdade e da ação correta, e agir de acordo com elas fornece o caminho pelo qual gradualmente (

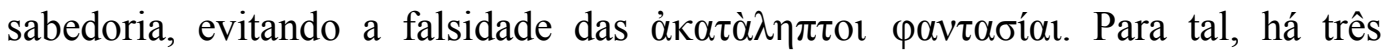
supracritérios que indicam quando uma impressão é cataléptica (1- a derivação de um objeto existente; 2- a representação acurada do tal objeto; 3- a impressão do objeto na mente através dos órgãos sensoriais), mas, de acordo com esses supracritérios, para os estoicos, a maioria esmagadora das impressões é cataléptica e assim, mesmo pessoas ordinárias agem em conformidade com elas. Contudo, as pessoas comuns agem de acordo com opiniões que se verificam verdadeiras, e suas ações não são louváveis, uma vez que não há um cálculo decisório como o do sábio estoico, que dá assentimento às impressões catalépticas porque sabe que elas indicam a verdade e o correto. Dessa forma, o conhecimento do sábio estoico é irrefutável e sua ação é inabalável:

\footnotetext{
${ }^{143}$ Ver: 'STRIKER, G. Estratégias céticas. BRITO, R. P.; SMITH, P. J. In: Breviário de filosofia pública, $\mathrm{n}^{\circ} 56,04 / 2012$.'
} 
... o sábio jamais confiará em simples opiniões, ou seja, jamais compactuará com o falso (...) somente o sábio é livre, mas os estultos são servos, pois a liberdade é a faculdade de agir independentemente e a servidão é a privação dessa faculdade. (...) Além disso, os sábios não são somente livres, mas são também reis, porque reinar é uma forma de domínio isenta de prestação de contas, que somente pode subsistir nas mãos dos sábios (...) são ainda inofensivos, pois não fazem mal a si mesmos nem aos outros. Eles também não são complacentes e nem perdoam seja quem for, nem deixam de aplicar as penalidades impostas pela lei. (D.L. VII, 121123).

Então, considerando que tal sábio presentemente não existia, Arcesilao voltou sua capacidade argumentativa e investigativa para analisar a filosofia daqueles que defendiam sua possibilidade, os primeiros estoicos, notadamente Zenão de Cítio. Sua motivação parece ter sido dupla e complementar: por um lado, queria, ao refutar o cerne da filosofia da Stoá, tornar-se ainda mais famoso em Atenas, reestabelecendo a glória da academia (PE. 14.4.8; Acad. pos.15-16); por outro lado, queria verificar a possibilidade da filosofia da Stoá realmente oferecer um caminho suficientemente eficaz para a obtenção da verdade e o alcance da sabedoria (Acad. pos. 76). Eis a reconstrução do debate por Cícero:

Nenhum dos predecessores de Zenão jamais explicitamente formulou, ou mesmo sugeriu o ponto de vista de que uma pessoa poderia não sustentar opiniões (hominem nihil opinari) - e não somente que poderia fazê-lo, mas que fazê-lo era necessário para o sábio (nec solum posse sed ita necesse esse sapienti). Arcesilao pensou que esse ponto de vista era tanto verdadeiro quando honrado, bem como correto para o sábio. Então perguntou a Zenão, podemos supor, o que aconteceria se o sábio não pudesse apreender nada, mas era uma marca da sabedoria não sustentar opiniões. Zenão respondeu, sem dúvida, que o sábio não sustentaria qualquer opinião porque haveria algo apreensível (Zenone fortasse quid futurum esset si nec percipere quicquam posset sapiens nec opinari sapientis esset. ille credo nihil opinaturum, quoniam esset quod percipi posset). Então, o que seria? Uma impressão (visum), suponho. Bem, que tipo de impressão? Zenão a definiu assim: uma impressão do que é, estampada, impressa e moldada como o que é (ex eo quod esset sicut esset inpressum et signatum et effictum). Após isso, Arcesilao prosseguiu perguntando o que aconteceria se uma impressão verdadeira fosse como uma impressão falsa. Nesse momento, Zenão foi esperto o suficiente para ver que nenhuma impressão poderia ser apreensível se uma que advém do que é fosse tal que houvesse outra semelhante, advinda do que não é (Zenonem vidisse acute nullum esse visum quod percipi posset, si id tale esset ab eo quod est cuius modi ab eo quod non est posset esse). Arcesilao concordou que essa era uma boa adição à definição, tendo em vista que nem uma impressão falsa, nem uma impressão verdadeira semelhante a uma falsa era apreensível. Então ele lançou-se a trabalhar nesses argumentos para demonstrar que não há impressão de algo verdadeiro, tal que não haja uma semelhante de algo falso. (Acad. pos. 77). ${ }^{144}$

${ }^{144}$ Compare com $A d v$. Log. I, 157: 'Se o sábio está entre os que assentem, o sábio está entre os que opinam ( $\tau \tilde{\omega} \nu \delta$ o $\xi \alpha \sigma \tau \iota \kappa \tilde{\omega} \nu$ ह̌ $\sigma \tau \alpha$ ó $\sigma o \varphi o ́ \varsigma)$. Mas o sábio, na verdade, não está entre os que opinam — pois, de acordo com eles [estoicos], a opinião é uma marca da tolice e uma causa de vícios portanto, o sábio não está entre os que assentem. E, se assim é, ele necessariamente recusará o 
Talvez retoricamente, Arcesilao concedeu a Zenão que o sábio não assente a opiniões, ele é infalível, mas, no caso de não haver algo sobre o qual se possa estar certo, por que não há impressão cataléptica, somente se pode ser tão infalível quanto o sábio ideal se recusar-se a assentir, uma vez que não há nada que previna contra o erro e o engano. Zenão tem que concordar que o sábio reterá o assentimento quando não tiver certeza e, embora essa seja uma (in)ação típica de um sábio presentemente inexistente, seus atos são exemplos para as ações dos homens ordinários. Então, o homem ordinário, diante da impossibilidade de conhecer o que é o certo, deve reter o assentimento, e sua retenção será ainda maior que a do sábio, uma vez que a maioria de suas ações é opinada, mesmo que sejam pragmaticamente corretas.

Assim, ele pode estar em situações em que não poderá distinguir entre a verdade e a falsidade das percepções, porque (1) as coisas que representam são objetivamente indiscerníveis umas das outras:

... alguém que olhasse para Publius Servilius Germinus e pensasse que estava olhando para seu gêmeo Quintus teria uma impressão não persuasiva (visum quod percipi non posset), porque suas impressões verdadeiras e falsas não são distinguíveis por qualquer marca. (...) Ainda, se não houver tal similaridade entre os homens, e quanto às estátuas? Está a me dizer que Lysippus não poderia ter feito uma centena de Alexandres, um igual ao outro, se tivesse usado o mesmo bronze, o mesmo processo, a mesma ferramenta, etc.? Diga-me qual marca você usaria para distingui-las! E quanto a estampar uma centena de selos do mesmo tipo na cera com seu anel? Você seria realmente capaz de encontrar um meio de distingui-los? (Acad. pos. 84-86).

$\mathrm{Ou},(2)$ porque o sujeito que percebe está com sua capacidade de discernimento afetada, como nos recorrentíssimos exemplos das ilusões, da loucura e dos sonhos (Acad. pos. 88-91).

Consequentemente, se, de acordo com os supracritérios estoicos, uma impressão é cataléptica quando indica com clareza como o objeto é em verdade, e a essa impressão se deve assentir; por outro lado, deve-se suspender o juízo (ou reter o assentimento) quando diante de impressões cujo discernimento não é claro. Então, se há uma zona de penumbra em que mesmo a diferença entre uma impressão cataléptica e uma não cataléptica não é clara (os exemplos objetivos e 
subjetivos citados acima), deve-se, de acordo com o próprio argumento estoico, suspender o juízo sobre a possibilidade de distinguir entre todas as impressões catalépticas das não catalépticas. Deve-se prescindir da necessidade da distinção entre as impressões como critério de verdade e da ação correta.

A resposta estoica (de Zenão) vem por três vias:

R1- se as pessoas comuns podem realmente ser confundidas em inúmeras situações, o sábio estoico, por seu turno, é capaz de discernir entre os dois tipos de impressão (Acad. pos. 20, 56-58);

R2- fazendo a asserção metafísica e não evidente de que duas coisas não podem idênticas ( $\dot{\alpha} \pi \alpha \rho \alpha \lambda \lambda \alpha \xi \dot{i} \alpha)$ (Acad. pos. 50, 54-56);

R3- acusando que os acadêmicos, ao pretenderem suspender o juízo sobre a possibilidade de distinção, pretendem suspender o juízo sobre tudo e incorrem em $\alpha \dot{\pi} \rho \alpha \xi i ́ \alpha$, não podem viver.

Os acadêmicos (Arcesilao) contra argumentam como se segue:

CA 1- se o sábio estoico é capaz de discernir entre o falso e o verdadeiro, apesar das dubiedades, ele é o derradeiro supracritério, além dos outros três mais anteriores. E, se assim é, então o critério de sabedoria do sábio é ele mesmo, e isso é uma inaceitável circularidade (SVF III, 138 em diante);

CA 2- se é necessária uma distinção não evidente, como o homem comum pode saber de sua realidade? Talvez o sábio estoico, por ser sábio, saiba, mas, uma vez que ele é o critério de sua própria sabedoria, voltamos a CA 1 (e a SVF III, 138 em diante).

Agora, nos detenhamos com mais detalhes ao argumento de Arcesilao contra a

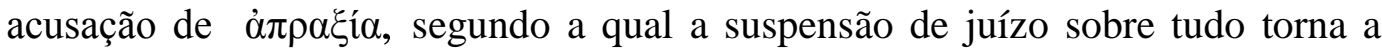
vida impossível (CA 3).

Para os estoicos, os seres humanos se diferenciam dos outros animais

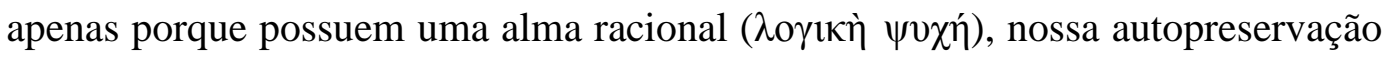

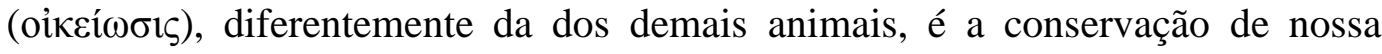

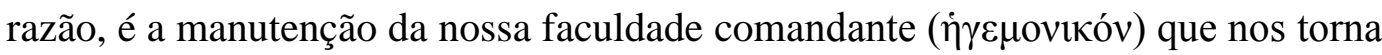

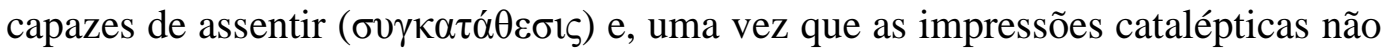


são coercitivas de sua verdade, devemos assenti-las, tornando nossas ações louváveis e sábias.

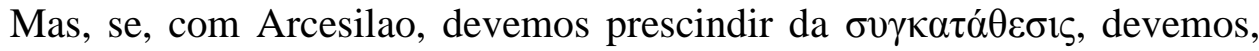

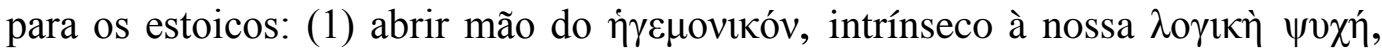
que nos define como humanos, então, isso é o mesmo que prescindir de nossa própria natureza humana e, uma vez que não podemos viver de outro modo, de

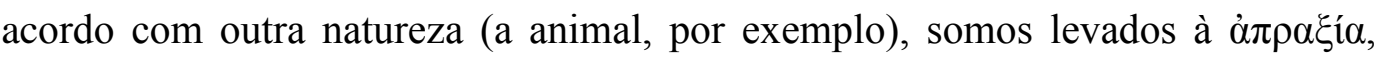

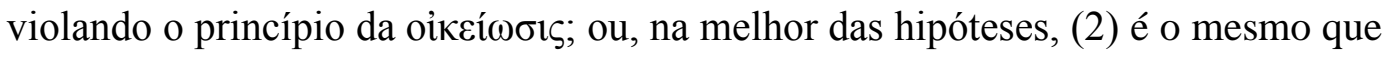
abrir mão da felicidade, tendo em vista que ela só é atingível se agirmos de acordo com as impressões catalépticas que, para tal, precisam ser distinguidas e conhecidas.

A saída de Arcesilao para os dois aspectos da acusação da $\alpha \dot{\pi} \rho \alpha \xi i ́ \alpha$ recorre mais uma vez à própria argumentação e conceitos da Stoá, dessa forma, para ele, se retivermos o assentimento, não obstante, teremos uma regra para a ação, o

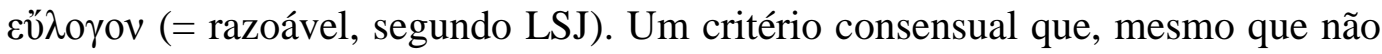

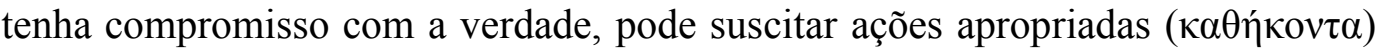
ou corretas $(\kappa \alpha \tau \rho \rho \theta \omega ́ \mu \alpha \tau \alpha)$, considerando a repetição dos fenômenos e a probabilidade, tornando a felicidade disponível ( $A d v$. Log. I, 158).

Então, àqueles que questionavam

... como pode alguém que suspende o juízo não correr para uma montanha ao invés de para a banheira, ou levantar-se e encaminhar-se para aporta ao invés de para a parede quando pretende ir ao mercado? (Adv. Col. 1122E; compare com Acad. pos. 37-38).

Arcesilao (usando os conceitos da Stoá, enfatizo) responde que

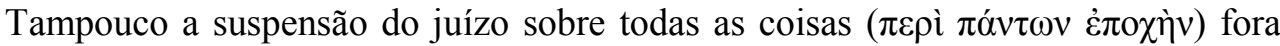
abalada por aqueles que se empenharam nisso, e escreveram longos argumentos contra ela. Mas, tendo os da Stoá, como uma Górgona, a confrontado com a inatividade ( $\dot{\alpha} \pi \rho \alpha \xi i ́ \alpha v)$, desapareceram, uma vez que por todos seus movimentos e reviravoltas, o impulso recusou-se a se tornar assentimento, e não aceitou a sensação como equilibrando a balança, mas foi visto como levando à ação por sua própria iniciativa, sem precisar do assentimento (...) Para aqueles que estão atentos e escutam, o argumento decorre assim. A alma tem três movimentos: impressão,

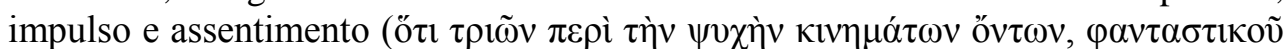

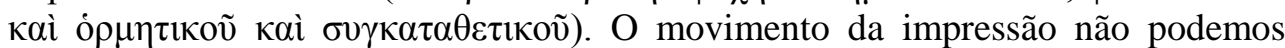

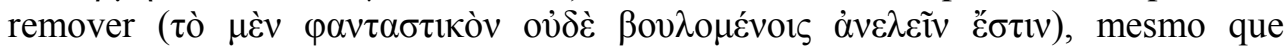
quiséssemos; mas, no momento em que encontramos coisas, temos uma impressão

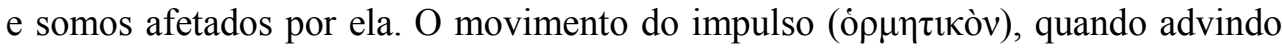
daquela impressão ( $(\alpha \nu \tau \alpha \sigma \tau \imath \kappa o \tilde{)}$, ativamente move uma pessoa aos objetos 


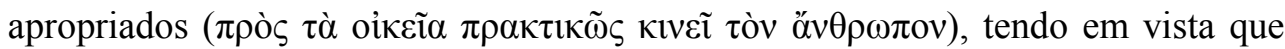
ocorre um tipo de mudança de escala e inclinação (...) Então, aquele que suspende

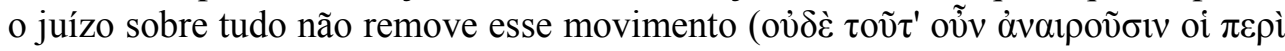

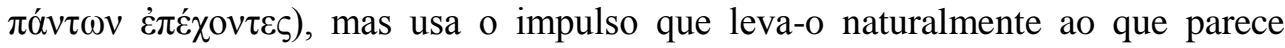

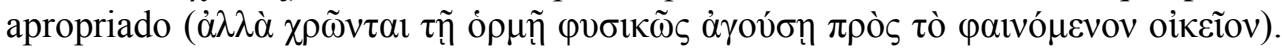
Qual é, então, a única coisa que evitam? Somente aquilo no que a falsidade e a decepção são engendrados - a opinião e o assentimento precipitado (...) Pois a ação requer duas coisas: uma impressão de algo apropriado, e o impulso em direção ao objeto apropriado que apareceu; nenhum desses está em conflito com a suspensão do juízo. (Adv. Col. 1122A-F).

Por hora basta de Arcesilao, passemos a frente e vejamos como Carnéades, se comportou nos debates.

\subsection{Carnéades $\mathrm{X}$ estoicos e epicuristas}

Primeiramente, devemos recordar que foi Carnéades quem, junto com dois outros filósofos (o peripatético Critolau e o estoico Diógenes), foi enviado como embaixador de Atenas a Roma, e em um dia defendeu longamente aspectos das filosofias de Platão e de Aristóteles, e em outro as refutou, causando horror a Marco Catão (bisavô do homônimo estoico) e a outros romanos que imaginavam que com isso o acadêmico depreciava a justiça, perigosamente fazendo-a parecer meramente convencional. Ora, a capacidade de Carnéades de argumentar pró e contra qualquer assunto deve ser vista como um aprimoramento da habilidade dialética de Arcesilao, de tal modo que mesmo Clitômaco, seu discípulo, "afirmou que nunca poderia saber qual ponto de vista Carnéades aprovava" (Acad. pos. $139)^{145}$.

Marco Catão também se escandalizou com os argumentos teológicos de Carnéades $^{146}$, que abalavam as crenças na existência de deus como ser vivo, eterno e benevolente. Então, voltando à física estoica (ou teologia), se considerarmos que deus e natureza se confundem e que a natureza é viva, então deus igualmente é um ser vivo, e sensível ${ }^{147}$, mas, segundo a definição estoica de sensação como um tipo de alteração:

\footnotetext{
${ }^{145}$ Ver: 'BICCA, L. Carnéades em Roma: ceticismo e dialética. In: Revista Sképsis, ano IV, n 05, 2009.'

${ }^{146}$ Ver Vit. Par. Vida de Marco Catão.

${ }^{147}$ Recordai os argumentos de Crisipo que aparecem em nossa seção sobre a física da Stoá: D.L. VII 142-143; e ND II 21-22.
} 
Se deus é alterado, ele é receptivo às alterações e mudanças; e sendo receptivo à mudança, ele certamente será suscetível à mudança para pior. E, se assim é, ele também é perecível. (Adv. Phy. I, 146-147).

Assim, se aderir-se ao dogma de que deus é um ser sensível, ter-se-á que rejeitar o dogma de sua eternidade, dado que são dogmas mutuamente excludentes quando interpretados à luz do sistema da Stoá. O único modo de resolver a aporia é optar:

(1) ou deus é eterno - e não é sensível, porque: (a) não pode ser alterado, nem para melhor e nem para pior; ou (b) é sensível, sim, mas a recepção

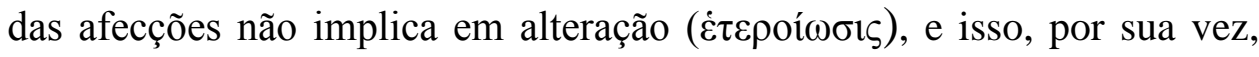
vai contra o conceito estoico de $\varphi \alpha v \tau \alpha \sigma i ́ \alpha$ (= impressão = alteração na alma), passo que deve ser evitado a todo custo pelos estoicos, considerando que conduz à rejeição de seu conceito mais importante.

(2) Ou deus é sensível - e não é eterno, e consequentemente não há a recorrência eterna dos ciclos cósmicos.

Por seu turno, segundo o dogma físico/ético da infinita virtude divina (que gerava o postulado da virtude absoluta da natureza, e se recordarmos de nossa exposição da ética estoica, que pregava que ser totalmente virtuoso e sábio era agir totalmente conforme a natureza e deus), a virtude de deus seria qualificada por disposições humanas: benevolência, por exemplo, e também seria parâmetro para a virtude do sábio, de modo que a rejeição da benevolência divina implicaria na rejeição do $\tau \varepsilon ́ \lambda o \varsigma$ ético estoico. Eis como funciona o argumento de Carnéades:

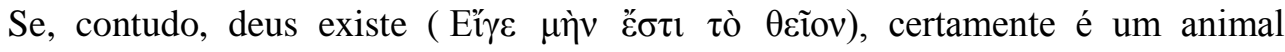
[segundo os estoicos]. E, se é um animal, certamente tanto é totalmente virtuoso e

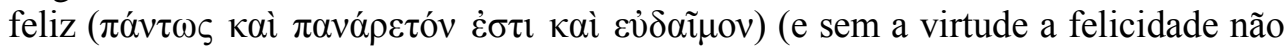
pode subsistir). E se é totalmente virtuoso, ele possui todas as virtudes. Mas ele não possui todas as virtudes a não ser que possua também domínio de si

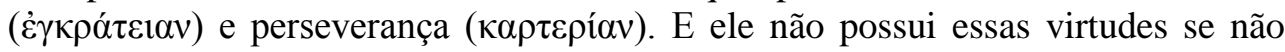
houver certas coisas que sejam difíceis para ele abster-se, e duras de suportar. (...) Haverá, então, certas coisas difíceis para ele suportar, e difíceis de abster. Pois, se essas não existirem, ele não possuirá essas virtudes, a saber, o domínio de si e a perseverança. E se ele não possui essas virtudes, uma vez que nada há entre a

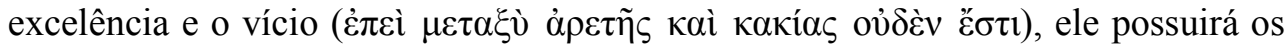
vícios contrários a essas virtudes, como frouxidão ( $\mu \alpha \lambda \alpha \kappa i ́ \alpha v)$ e fraqueza de

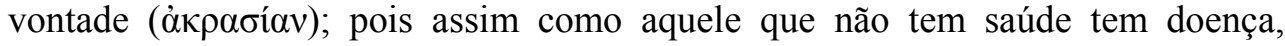


aquele que não tem continência e força é sujeito aos vícios opostos, o que é algo absurdo de se dizer sobre deus. (Adv. Phy. I, 152-157). ${ }^{148}$

E:

... se um ser não deve participar do mal, é preciso que ele faça uma escolha entre as coisas boas e as más, e que necessidade tem ele de razão e conhecimento? Nós aplicamos essas faculdades para avançarmos do que é evidente para o que é oculto, mas nada está ocultado de deus. Pois a justiça, cuja distribuição cabe a ela própria, não tem relevância para os deuses, pois como vocês [estoicos] colocam, ela nasceu quando os homens [uniram-se] em comunidades e sociedades (Nam iustitia, quae suum cuique distribuit, quid pertinet ad deos; hominum enim societas et communitas, ut vos dicitis, iustitiam procreavit). A temperança consiste em renunciar aos prazeres do corpo; se esta virtude tem uma função no céu, deve também haver lugar lá para prazeres do corpo. (ND III 38). ${ }^{149}$

Além disso, o criativo Carnéades faz o paradoxo do owpítns, ou argumento do monte, outrora aplicado a qualquer quantidade indeterminada (pouco ou muito, por exemplo), agora ser aplicado à quantidade indeterminada de deuses do politeísmo grego:

Se Zeus é um deus (...) Poseidon, sendo seu irmão, também será um deus. Mas se Poseidon é um deus, o [rio] Aqueloo também será um deus. E se o Aqueloo é, também o Nilo é. Se o Nilo é, também são todos os rios. Se todos os rios são, córregos também deveriam ser deuses. Se córregos forem, torrentes também deveriam ser. Mas os córregos não são deuses. Portanto, Zeus tampouco é. Mas se há deuses, Zeus também deveria sê-lo. Portanto, não há deuses. (Adv. Phy. I, 182184).

Agora, esses argumentos contra as crenças em deus não são somente dirigidos aos estoicos, mas também aos epicuristas, uma vez que

Epicuro diz que os deuses são visíveis à nossa mente, sendo alguns numericamente distintos, enquanto outros aparecem uniformemente do influxo contínuo de imagens similares dirigidas ao mesmo ponto e com a figura humana. (D.L. X, 139).

Mas também se dirigem aos homens comuns, politeístas no contexto religioso grego (e nos contextos romano, céltico, macedônico, mesopotâmico, egípcio e fenício; Helenístico, em suma).

${ }^{148}$ Para o argumento completo de Sexto Empírico acerca da atribuição de valores morais a deus, ver: Adv. Phy. I, 151-171).

${ }^{149}$ Compare com a parte V dos Diálogos acerca da religião natural, de Hume: 'HUME, D. Dialogues concerning Natural Religion. In: David Hume: Philosophical Works, vol. II . Londres: Green and Grose, 1886'. 
Em um ataque diretamente contra as principais teorias éticas do período Helenístico, Carnéades apontou a inconsistência do $\tau \dot{\varepsilon} \lambda o \varsigma$ moral epicurista porque Epicuro algumas vezes concebia o prazer (†்oví) como um estímulo ativo dos sentidos, outras vezes como a ausência de dor, e uma forma de prazer não é necessariamente complementar à outra, inclusive, podem ser excludentes ${ }^{150}$ mas, mais uma vez, seu alvo favorito são os estoicos, notadamente Crisipo de Sólis, assim, contra a ética da Stoá, Carnéades deteve-se na frágil distinção

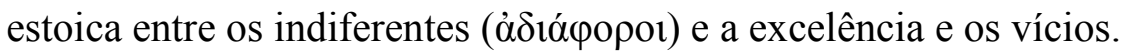

Assim, segundo a abordagem mais tradicional da ética estoica, que perdurou pelo menos até Posidônio, os indiferentes são considerados como tal porque podem ser vantajosos tanto para facilitar o alcance da excelência quanto do vício, e também por não serem desejáveis por si mesmos, dessa forma, a vitalidade pode ser tão valorosa para um assassino (otimizando seu vício), quanto para o sábio (otimizando sua excelência). Mas, para os sábios, de fato, qualquer dos indiferentes é rigorosamente indesejável por si só, os bens externos não são alvos morais, somente a sabedoria deve ser, então, uma vez (e tão-somente) alcançada a excelência, o sábio se torna feliz, e ele pode ser feliz pobre e moribundo, desde que seja simplesmente sábio. Não obstante, se a vitalidade, por exemplo, é tão valorosa para o assassino quanto para o sábio, por que não dizer que ela é valorosa em si, bem como a riqueza, a saúde e todos os bens corporais externos?

Eis o dilema estoico: ou (1) assumem de uma vez por todas que os bens corporais externos são verdadeiramente bons, e desejáveis por si sós; ou (2) rejeitam-nos peremptoriamente. Mas, se agirem conforme (1), os estoicos redundariam em peripatéticos, e, se agirem conforme (2), redundariam em cínicos, pelo menos do ponto de vista dos resultados pragmáticos de sua teoria ética $^{151}$.

Agora, quanto à discussão da teoria estoica dos indiferentes, o objetivo de Carnéades não é meramente lançar aporias, mas demonstrar que o que importa nas ações não são as teorias que as fundamentam, mas seu resultado pragmático e, para ações corretas, há um critério prático consensual e extraído da vida dos homens ordinários: ó $\pi \imath \alpha$ $\theta$ ó $(\mathrm{LSJ}=$ o persuasivo, plausível).

\footnotetext{
${ }^{150}$ Ver: D.L. X, 128-129; compare com De Fin. 1.

${ }^{151}$ Ver: Tusc. 5.120; De Fin. 3.41.
} 
Segundo a base de dados Diógenes, há 1677 ocorrências para os vocábulos $\pi \imath \theta \alpha v o ́ v$ (forma neutra de $\pi \imath \theta \alpha v o ́ \varsigma$ ) e seu antônimo ả $\pi i \theta \alpha v o v$, em sua maioria são casos em que a responsabilidade da persuasão recai sobre o orador (ver: Tuc. 6.35; Górg. 458e, 479c; Poet. 1455a; Orest. 906; Hisp. 15), ou sobre o próprio discurso (ver: Fed. 88d; Teet. 178e; Rhet. 1356b26, 1403b20), com vistas a suscitar a obtenção da vitória nos debates (ver: Mem. 3.10.3). Em todos os casos, trata-se de uma noção inicialmente adotada pela sofística e oratória, depois assimilada por outros campos do saber.

Mas, além disso, a chegada ao plausível (ou persuasivo) como critério de ação recorre a um argumento epistemológico, lançado por Carnéades

... não somente contra os estoicos, mas também contra todos antes dele. De fato, seu primeiro argumento, que é dirigido contra todos eles juntos, é aquele segundo o qual ele fundamenta que nada está qualificado para ser um critério de verdade: nem a razão, nem a percepção sensível, nem as aparências, tampouco qualquer coisa que haja; pois todas elas em conjunto desapontam-nos. (Adv. Log. I, 159).

Não obstante quais sejam as considerações que se faça sobre um critério, ou qualquer que ele seja (sentidos ou razão, por exemplo), ele deve sempre servir como uma fronteira entre o verdadeiro e o falso, tanto em âmbito epistemológico

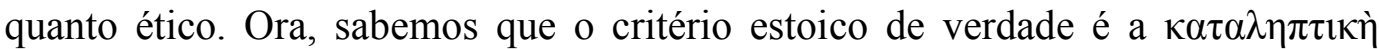

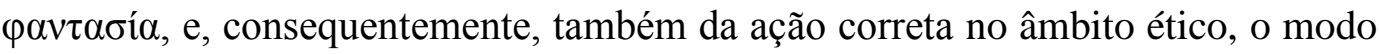
pelo qual o homem pode se dirigir da vida tola à sábia. Assim, seguindo e aprofundando o ataque de Arcesilao, Carnéades distingue na impressão dois aspectos: sua relação com o objeto que ela representa e sua relação com o sujeito que a percebe. Então, se a impressão representa acuradamente o objeto, ela é verdadeira; por outro lado, se convence o sujeito de que realmente é verdadeira, levando-o a assentir, é persuasiva (e plausível). Ademais, se uma impressão é verdadeira, isso independe do sujeito que percebe, uma vez que sua verdade se dá através de sua conformação com o objeto que a gera; e também, se ela é persuasiva, isso independe do objeto, uma vez que a impressão persuade o sujeito, tanto da verdade quanto da falsidade.

Se realmente estivermos, enquanto sujeitos, submetidos exclusivamente ao caráter persuasivo das impressões, e, além disso, se não tivermos um critério para discernir a verdade, considerando que verdade e falsidade são conhecidos e asseridos a partir da conformidade das impressões com os objetos 
correspondentes, e não conforme qualquer critério subjetivo (para os estoicos), então deveríamos prescindir totalmente da categoria "verdade" para pautar nossas ações e nosso conhecimento, bastariam a persuasão e a plausibilidade.

Por outro lado, se os estoicos retrocedessem e argumentassem que a "verdade" se situava no eixo impressão/sujeito, Carnéades estava preparado para reutilizar os argumentos já usados por Arcesilao (e Homero, Heráclito, Protágoras, Zenão de Eléia, Leucipo, Demócrito, Pirro, Timão...) que demonstravam a dubiedade da razão e dos sentidos dos seres humanos, frágeis, volúveis e inconstantes, a despeito da solidez monolítica da pretensa sabedoria do sábio estoico idealizado ${ }^{152}$.

Como já era de se esperar, diante de uma tão devastadora confutação, os estoicos reagiram, treplicando que a mente deveria ser devidamente treinada através da lógica para eliminar as interferências que por ventura pudessem afetar o discernimento, uma vez que isso fosse feito e os obstáculos para o conhecimento fossem removidos, as impressões corretas impeliriam ao assentimento, como se puxassem pelos cabelos ( $A d v$. Log. I, 257). Dessa forma, o sábio seria capaz de proficientemente discernir as impressões catalépticas das outras, utilizando seu treinamento lógico e epistemológico para que a ação nunca fosse precipitada e ele nunca fosse tentado a assentir ao falso.

Mesmo adicionando um critério além para a verificação da veracidade da impressão, isso não satisfez Carnéades que continuou a rejeitar a impressão cataléptica e persistiu na suficiência do persuasivo como critério pragmático para a ação. Por seu turno, os estoicos também persistiram argumentando que sem a impressão cataléptica, não há critério para a ação correta, tendo em vista que tudo seria incerto (Acad. pos. 32), e consequentemente a vida seria impossível

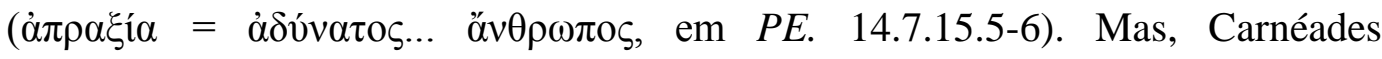
argumentou que há diferença entre algo ser incerto e ser não evidente, e se, por um lado, tudo é incerto, por outro lado, nem tudo é não evidente (ver $P E$.

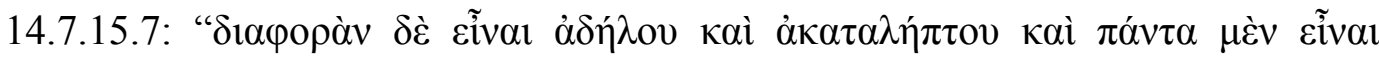

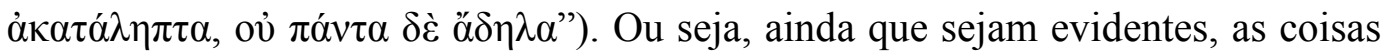
são incertas, uma vez que podemos ser enganados e mesmo assim assentir erroneamente, então deveríamos suspender o juízo e agir exclusivamente

${ }^{152}$ Ver: Acad. pos. 47-49. 
conforme a persuasão causada pelos fenômenos, eis o critério derradeiro para a ação (PE. 14.7.15.5).

Consequentemente, se o persuasivo é suficientemente eficiente no âmbito da ação prática, por outro lado, em epistemologia, representa uma ruptura com a exigência Helenística tradicional do critério para o conhecimento e para a verdade. Nesse sentido, podemos entender a posição de Carnéades como um clamor para que os homens abandonassem as teorias morais e se ativessem à pragmática, onde as impressões persuasivas são um critério que não só não conduz à inatividade, mas, além disso, torna a vida possível:

O ponto de vista de [Carnéades] é de que há duas categorias de impressões, a primeira subdividida através do princípio de que algumas são apreensíveis, e algumas não, a segunda, através do princípio de que algumas são persuasivas, outras não. Ora, os argumentos acadêmicos contra os sentidos e contra a perspicuidade referem-se à primeira categoria, e não devem ser dirigidos à segunda. Assim, seu ponto de vista, como diz Clitômaco, "é que, enquanto não há impressões que se possa apreender, há muitas que se pode aprovar. Seria contrário à natureza se não houvesse impressões persuasivas" - e o resultado seria a completa subversão da vida... (Acad. pos. 99).

Segundo Sexto Empírico (P.H. I, 230), Carnéades deliberadamente escolheu aderir a determinadas impressões, fazendo-as seu critério para ação prática, diferentemente de Arcesilao que evitava o assentimento e a adesão a um tipo de impressão específico em detrimento de outros. Então, com Carnéades começa o enrijecimento de um critério dogmático, e não cético.

\subsection{Clitômaco, Filo de Larissa, Antíoco, Cícero, Enesidemo e Agripa}

Como nosso objetivo vem sendo demonstrar o surgimento dos argumentos contra o ceticismo antes de Sexto Empírico, bem como o aparecimento das fórmulas céticas, ambos em uma perspectiva dialética, não devemos nos alongar demasiadamente na fase que vai de Clitômaco a Agripa, que, por outro lado, por razões históricas, não poderia ser omitida.

Após a morte de Carnéades (circa 128 a.C.), Clitômaco, um escritor prolífico a quem se atribui em torno de 400 livros, se tornou líder da academia. Seus escritos eram largamente inspirados pela filosofia de seu mestre, e também pelo seu critério teórico pretensamente pragmático (portanto, dogmático) para as 
ações: o persuasivo, vindo a influenciar seu seguidor Filo de Larissa que, por seu turno, se tornou líder da academia em circa 110 a.C.

Inicialmente, Filo foi um seguidor estrito dos ensinamentos de Clitômaco e pretendeu dar-lhes uma maior coesão interna, mas, em um segundo momento,

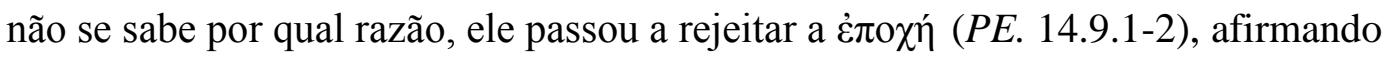
que, como condição de existência, os objetos deveriam ser naturalmente apreensíveis (P.H. I, 220), embora não necessariamente de acordo com a epistemologia estoica.

Antíoco de Ascalão (circa 130-68 a.C.) discordou completamente das asserções de Filo, que foram recebidas como uma traição à filosofia de Platão (Acad. pri. 17-18). Assim, em represália, Antíoco rompeu com a academia sob Filo e alinhou-se ao estoicismo, pretendendo eliminar as divergências entre as filosofias através do ecletismo (Acad. pos. 18-31).

Marco Túlio Cícero (103-46 a.C.), uma de nossas melhores fontes para reconstruirmos as principais doutrinas e os debates entre acadêmicos e estoicos, passou pela academia na mesma época de Filo e Antíoco (e pela Stoá na época de Panécio e Posidônio de Rodes, cidade em que também foi aluno do orador Apolônio Mólon), sua seminal e prolixa obra em latim apresenta-nos um posicionamento eclético, mas os vestígios da filosofia acadêmica que restam são decorrentes de sua adesão ao provável e verossímil (respectivamente, probabile - com 68 ocorrências em suas obras - e veri simile - com 60 ocorrências). Além disso, Cícero é o principal responsável por apresentar à Europa Moderna a

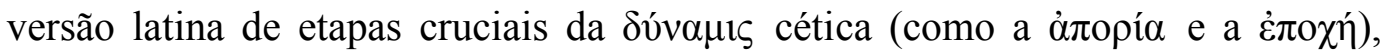
entendidas e traduzidas como dubitare, com o total de 122 ocorrências em suas obras, suscitando muitos equívocos (como a interpretação do ceticismo como um procedimento dubitativo artificial que compromete a própria existência do mundo externo, e que serve como ponto de partida para erigir dogmatismos).

Como Filo, Antíoco e Cícero, por exemplo, não permaneceram em Atenas, mas foram para Roma, cessaram-se em Atenas as atividades da academia.

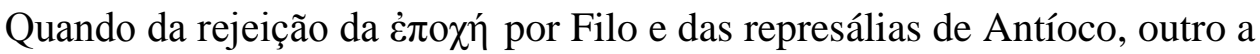
desertar da academia foi Enesidemo, que pensava que o debate entre esses contentores consistia em "estoicos lutando contra estoicos" (Bib. 170a14-17), e, ao invés de alinhar-se a qualquer outra escola de sua época, pretendeu reviver o pirronismo. Na mesma proporção em que é obscuro, Enesidemo também é 
controverso e importante, porque sobre ele nada se sabe a não ser que viveu no séc. I a.C, escreveu pelo menos um livro ('Discursos Pirrônicos'), infelizmente quase todo ele perdido, a não ser por fragmentos preservados principalmente na obra supracitada de Fócio, e polemicamente pensava que o pirronismo era uma etapa para o heraclitismo. Mas a maior contribuição de Enesidemo, além de fazer ressurgir o pirronismo, foi arquitetar uma organização dos tão recorrentes

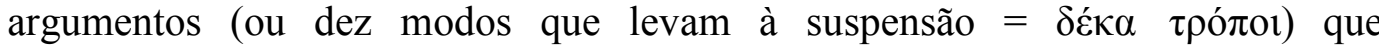
demonstram que há situações em que o julgamento é impossível, ou porque o sujeito que julga não tem condições de fazê-lo, ou porque o objeto não tem condições de ser julgado, ou ambos simultaneamente (P.H. I, 38; ver P.H. I, 36164, compare com D.L. IX, 79-88), e também dos oito modos pelos quais se pode refutar a noção de causalidade (P.H. I, 180-187, compare com D.L. IX, 98-99).

Ainda mais obscuro que Enesidemo, Agripa (circa séc. I d.C.) foi, segundo D.L. IX, 88-90 (compare com P.H. I, 164-178, em que não há a referência ao nome do autore dos $\tau \rho o ́ \pi o 1)$, o autor de outros cinco tropos que, com a exceção de um, são dirigidos à forma dos argumentos dogmáticos, e não ao seu conteúdo.

Embora todos os tropos sejam cruciais para os céticos nos debates com os dogmáticos, como nosso objetivo aqui é outro e como eles merecem ser objetos de estudo por si sós, devemos passar ao largo deles e somente citá-los na medida em que for interessante.

Finalmente, após Enesidemo e Agripa o pirronismo se infiltra nas discussões e seitas médicas, com Zeuxipos, Zeuxis, Antíoco de Laodicéia, Menodoto de Nicomédia, Teodás de Laodicéia, Heródoto de Tarso, Sexto Empírico e Saturnino (ver: D.L. IX, 116). Excluindo Sexto Empírico, que será nosso objeto de estudo mais a frente e cujas obras chegaram até nós, todos os outros são praticamente desconhecidos ${ }^{153}$.

Assim, pensamos ter coberto toda a história do ceticismo Antigo antes de Sexto Empírico, e também (e principalmente) (1) as aquisições dos seus conceitos, (2) as ocorrências dos ataques anticéticos e (3) as réplicas aos ataques.

\footnotetext{
${ }^{153}$ Para uma tentativa de reconstrução da infiltração do pirronismo nos círculos médicos, bem como da cronologia dos pensadores citados, ver: 'BROCHARD, Victor. Os Céticos Gregos. São Paulo: Editora Odysseus, 2010'.
} 


\section{Problemas na interpretação de Sexto Empírico}

\subsection{O legado do ceticismo até Sexto}

Se nossa investigação acerca dos contextos das gêneses do vocabulário cético tiver sido feliz, podemos dizer que Sexto Empírico, principal fonte do ceticismo pirrônico, herdou:

(a) dos protocéticos: a percepção da ambivalência dos sentidos e da conduta humana; as ámopíar quanto aos mitos, as possibilidades do conhecimento e do movimento; o relativismo; a fórmula ov̉ $\mu \tilde{\alpha} \lambda \lambda o v$; e a percepção de que a vida humana é pautada tão-somente em convenções e que somos coagidos por afecções sensíveis.

(b) De Pirro: a necessidade de atestar que o cético é um homem comum, fazendo-o ativo em uma $\tau \dot{\chi} \chi \eta \eta$; uma desconfiança constante das 'verdades'; indiferença e impassibilidade moderadas; a vida alheia às coisas públicas (pelo menos dentro das possibilidades da $\tau \dot{\varepsilon} \chi v \eta$ em que se é ativo); e a rejeição da retórica sofística.

(c) Dos sucessores de Pirro: a exortação de que o pirronismo é uma conduta prática; a belicosidade e o sarcasmo contra os dogmáticos; a rejeição de disciplinas escolares (tanto quanto permitido pela $\tau \dot{\varepsilon} \chi v \eta$ em que se conserva ativo); a investigação de diferentes culturas; e a submissão das investigações a um $\tau \varepsilon ́ \lambda o \varsigma$ moral.

(d) De Arcesilao: a compreensão de que para cada percepção e argumento há outros iguais e contrários (equipolentes); e a retenção do assentimento.

(e) De Carnéades: a eleição definitiva dos estoicos como alvos favoritos; os ataques mais específicos às físicas e éticas; o emprego calculado de ferramentas lógicas utilizadas pelos próprios dogmáticos; e a noção de que o que importa nas ações são seus resultados pragmáticos.

(f) De Clitômaco: o encorajamento ao conhecimento profundo das doutrinas dogmáticas. 


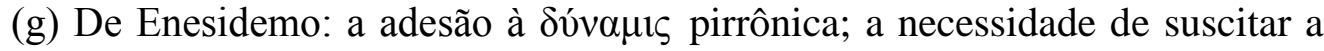

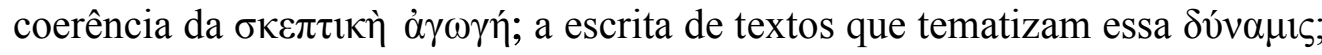
e o uso ferramental dos dez tropos que apontam que há situações em que o julgamento é impossível, e dos oito tropos contra a causalidade.

(h) De Agripa: o uso ferramental dos cinco tropos dirigidos às formas dos argumentos dogmáticos.

(i) Da infiltração nas seitas médicas: a submissão do pirronismo a uma forma de terapia discursiva e todas as recorrentes metáforas médicas e purgativas.

Mas, por outro lado, Sexto Empírico também herdou um acúmulo de críticas teimosamente recursivas que atacam diferentes pontos do que veio a ser

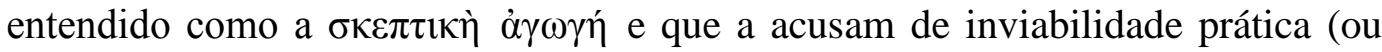
inatividade $=\dot{\alpha} v \varepsilon v \varepsilon \rho \gamma \eta \sigma i ́ \alpha)^{154}$ - inclusive afirmando que o ceticismo depõe contra a própria vida (humeanamente, eu diria, se não fosse anacrônico) - e também de inviabilidade discursiva (obviamente, um outro aspecto do argumento da inviabilidade prática, mas que se dirige à prática comunicativa), por que o cético, ao comunicar-se, (1) autorefuta-se, por que um discurso pressupõe uma verdade, e assim, (2) o emissor fala o que considera ser verdadeiro, e, se assim não for, (3) ao invés de comunicar-se, o cético deveria calar-se.

Além desses problemas, considerando que Sexto era médico e que prescrevia o ceticismo como terapia, ele não estaria sendo dogmático ao fazê-lo? Prescrever algo não significa um atestado da crença de que este algo é o melhor, ou o mais eficaz? Ademais, ocupar-se em todo um corpus filosoficus de um tema não denota uma adesão ao tema como uma espécie de corrente filosófica?

Vejamos também o caso do buscador: diante da inquietude causada pela busca, escolher o ceticismo como via para obter a imperturbabilidade não é uma opção dogmática? Consultar um guia argumentativo que demonstre a fraqueza das proposições dogmáticas ao construírem raciocínios que pretendam entender o 'funcionamento' dos fenômenos, ao nos porem em contato com real, e de suas aparentes leis (a causalidade, por exemplo) não seria também dogmatismo?

\footnotetext{
${ }^{154}$ Em Sexto Empírico não há ocorrências do vocábulo $\alpha$ $\pi \rho \alpha \xi i ́ \alpha$ para referir-se à inatividade, ao

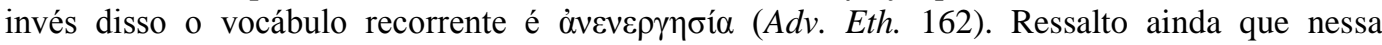
passagem Sexto está a citar um fragmento de Crisipo (Chrysippus Phil., Fragmenta logica et physica, Fr.119), dessa forma, o argumento aqui levantado contra a viabilidade prática do
} 
Mais uma vez, embora (até onde podemos saber) as críticas imediatamente acima não tenham sido feitas na época de Sexto e diretamente contra ele, elas de fato são problemas hoje para aqueles que tentam interpretar os escritos sextianos, e devem ser refutadas por aqueles que pretendem defender a possibilidade pragmática do ceticismo pirrônico.

Assim, na busca pela compreensão do significado do pirronismo e de sua viabilidade prática, comentadores, historiadores das ideias e filósofos tentaram interpretá-lo. Richard Popkin nos indicou o enorme peso dos argumentos céticos na história das ideias, para ele o ceticismo foi um dos principais elementos constituintes do pensamento Moderno. Mas, o ceticismo Moderno possui características distintivas e temáticas que eram ausentes no ceticismo Antigo: a dúvida como procedimento positivo (e que chega a se dirigir à totalidade do mundo externo), o fideísmo, o caráter quase que exclusivamente epistemológico, e também o insulamento, são os exemplos mais expressivos.

Não obstante o ceticismo já fosse um tema constante de pesquisas desde o séc. XIX (ver Brochard, por exemplo), foi após Popkin que uma variedade ainda maior de interpretações dos ceticismos Antigo e Moderno passou a vigorar. Contudo, a partir da década de 1970 começou a haver um alinhamento entre essas diversas interpretações, surgindo assim duas correntes interpretativas que vieram a ser conhecidas como 'rústica' e 'urbana' e que passaram a disputar a hegemonia ${ }^{155}$.

ceticismo remonta a Crisipo, e é a ele que Sexto Empírico pretende refutar nos passos Adv. Eth. $162-168$.

${ }^{155}$ Desse modo, segundo Barnes ('The Beliefs of a Pyrrhonist. In: Proceedings of the Cambridge Philological Society, $n^{\circ}$ 208. Cambridge, 1982') podemos caracterizar as posturas rústica e urbana da seguinte forma: 'Um intérprete que encontra o pirronismo rústico em $P H$ apelará inicialmente a duas características da obra de Sexto. Primeiro, muitos dos argumentos em $P H$ parecem demolir todas as crenças quanto a determinado tópico se demolem todas as crenças: os ataques à causalidade ou ao tempo ou à verdade, digamos, não parecem restringir seus alvos a posições científicas ou filosóficas nessas áreas; e os cinco tropos de Agripa, em termos aos quais muito da argumentação de $P H$ é conduzida, parecem ser totalmente indiferentes a quaisquer distinções entre teoria científica e opinião cotidiana. Em segundo lugar, $P H$ esclarece que os oponentes do pirronismo regularmente construíram o pirronismo de maneira rústica - o notório argumento de que os céticos não podem agir evidentemente pressupõe que os pirrônicos não têm quaisquer crenças. (...) Um intérprete que encontra o pirronismo urbano em $P H$ também apelará inicialmente a duas características da obra de Sexto. Primeiramente, Sexto frequentemente caracteriza o pirronismo referindo-se aos seus oponentes, os 'dogmáticos': 'o cético, sendo um filantropo, deseja curar pelo discurso, no melhor de sua habilidade, a pretensão e a precipitação dos dogmáticos' (PH III, 280). O pirronismo é uma terapia, uma cura da doença mental induzida pelos cientistas, filósofos, e outros charlatães sabidos: ele não se preocupa com as crenças ordinárias dos homens ordinários. Em segundo lugar, Sexto frequentemente apresenta-se como o campeão da ßíos, da vida ordinária ou do senso comum. Como Berkeley, ele está eternamente atacando as 


\subsection{A interpretação rústica e a urbana}

Pelo lado dos 'urbanos', o artigo fundamental data de 1979 e foi escrito por Michael Frede ${ }^{156}$, e mesmo em alemão teve bastante repercussão entre os intérpretes britânicos do ceticismo Antigo. Mas foi somente depois de sua tradução para o inglês em 1989 que 'The Sceptic's Beliefs' ganhou maior notoriedade.

Em 1980, Myles Burnyeat publicou 'Can the Sceptic Live His Scepticism? ${ }^{157}$ propondo uma nova forma de interpretar o ceticismo Antigo que veio a ser conhecida como interpretação 'rústica'. Mesmo assim, nesse artigo ainda há diversos pontos de contato entre as visões de Frede e Burnyeat. Só mais tarde, com a primeira publicação de 'The Sceptic in His Place and Time,158, em 1984, que Burnyeat passou a defender uma interpretação do ceticismo de modalidade pirrônica radicalmente oposta à visão de Frede.

Tendo descrito esse cenário, nosso objetivo de agora em diante será entender o que significam as duas posições, a rústica e a urbana, para podermos entender a razão de evocarem-se certos filósofos para endossar uma ou outra postura interpretativa, ou uma ou outra réplica. Nosso objetivo mais geral é argumentar a favor de uma via interpretativa média entre as interpretações rústica

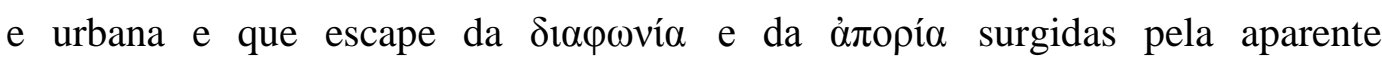

metafísicas e reduzindo os homens ao senso comum. Ele é um defensor, não um oponente, das crenças comuns'.

${ }^{156}$ Com o título original de 'Des Skeptikers Meinungen', apareceu pela primeira vez in: 'Neue Hefte für Philosophie', Heft 15/16 (1979), 102-129. Traduzido para o inglês como: 'The Skeptic's Beliefs', in: Michael Frede, 'Essays in Ancient Philosophy', (University of Minnesota Press, 1989), capítulo 10. Existe uma versão em português chamada 'As Crenças do Cético', in: Revista Sképsis:

http://www.revista-skepsis.com/pdf/139_03.pdf

157 Apareceu pela primeira vez in: 'Doubt and Dogmatism: Essays in Hellenistic Epistemology' (Claredon Press, 1980), capítulo 2. Reimpresso in: 'The Skeptical Tradition' (University of California Press, 1986), capítulo 6. Há uma versão em português desse artigo chamada: 'Pode o Cético Viver seu Ceticismo?', publicada em Trilhas Filosóficas: http://www.uern.br/outros/trilhasfilosoficas/conteudo/N_04/II_2_trad_Brito.pdf

${ }_{158}$ Apareceu pela primeira vez in: 'Philosophy in History: Essays on the Historiography of Philosophy' (Cambridge University Press, 1984), capítulo 10. Reimpresso em uma versão expandida in: 'Scepticism from the Renaissance to the Enlightement' (Wolfenbütteler Forschungen Band 35, Wiesbaden, 1987), 13-43. Há uma versão em português chamada: 'O Cético em Seu Lugar e Tempo'. publicada pela Revista Kínesis:

http://www.marilia.unesp.br/Home/RevistasEletronicas/Kinesis/Traducao.pdf 


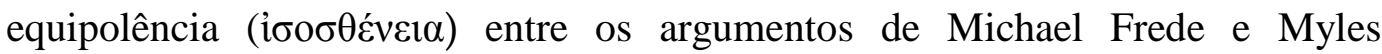
Burnyeat $^{159}$.

Voltando a 'The Sceptic's Beliefs', nesse artigo Frede inseriu-se em uma discussão que estava percorrendo o século $\mathrm{XX}$ acerca da possibilidade de se viver de modo genuinamente cético. Sua posição, que se tornou paradigmática ${ }^{160}$, foi a de que é possível viver ceticamente, porque ser cético não implica em um estado de inação e de afasia que conduzem a uma letargia semelhante ao estado de coma, desse modo, cairiam por terra as críticas de Hume, bem como as dos estoicos e de quem quer que afirme que o ceticismo redunda em $\dot{\alpha} \pi \rho \alpha \xi i ́ \alpha$ ou $\dot{\alpha} v \varepsilon v \varepsilon \rho \gamma \eta \sigma i ́ \alpha$.

Assim, como ponto de partida, Frede oferece uma definição do que diz ser "the usual interpretation of Pyrrhonean scepticism", para depois atacá-la:

\begin{abstract}
A interpretação usual do ceticismo pirrônico, é claro, atribui uma postura muito mais radical a esses céticos [do que a que atribui aos céticos acadêmicos]. De acordo com essa interpretação, o cético não somente afirma que não tem uma compreensão mais profunda das coisas, ele também afirma não conhecer nada; ele não somente não mantém quaisquer doutrinas céticas específicas, ele também não tem pontos de vista ou crenças sobre nada. Tal caracterização do pirronismo tipicamente fundamenta-se no seguinte: na medida em que o que está em causa é o conhecimento, o pirrônico, como um cético puro sangue, dificilmente pode assumir que conhece algo sem minar seu ceticismo; e, quanto às crenças, os céticos Antigos asseguram-nos que retêm o juízo sobre qualquer questão que está sob consideração. O cético recusa assentir a qualquer proposição.

Qualquer interpretação nessas linhas, contudo, parece-me fundamentalmente equivocada. Não importa quão ingênuo possa ser, o cético não pode evitar conhecer muitas coisas. (Frede, op. cit. Grifo nosso).
\end{abstract}

Em seguida, Frede envereda por uma breve consideração do argumento anticético da $\dot{\alpha} \pi \rho \alpha \xi i ́ \alpha$, que o leva a asserir que

É claro, os céticos Antigos, começando pelo menos com Arcesilao, estavam bastante familiarizados com essa objeção. Claramente, eles sentiram que ela verdadeiramente não depunha contra sua posição. Uma vez que a questão surgia de novo e de novo ao curso dos séculos, parece razoável supor que os céticos tinham,

\footnotetext{
${ }^{159}$ Reconheço meu débito com MARCONDES Souza Filho, D. ('Rústicos X Urbanos: o Problema do Insulamento e a Possibilidade da Filosofia Cética. In: O Que Nos Faz Pensar, n 24, 2008'; 'Ceticismo, Filosofia Cética e Linguagem. In: SILVA Filho, Waldomiro (org.). O Ceticismo e a Possibilidade da Filosofia. Ijuí: Editora Unijuí, 2005'; "A "Felicidade” do Discurso Cético: o Problema da Auto-refutação do Ceticismo. In: O Que Nos Faz Pensar, n 8, 1994'; 'Juízo, Suspensão do Juízo e Filosofia Cética. In: Sképsis, n 1, 2007'; 'Noûs vs Logos. In: O Que Nos Faz Pensar, n 1, 1989') e BARNES, J (op. cit. - reimpresso em 'Elenchos' 4, 1983; pp. 5-43, e foi anexado a Jonathan Barnes, 'Pyrrhonism, Belief and Causation: Observations on the Scepticism of Sextus Empiricus', Aufstieg und Niedergang der Römischen Welt Band 36.4 ,1990; pp.2608-95.

${ }^{161}$ Ver 'PEREIRA, Oswaldo Porchat. Rumo ao Ceticismo. São Paulo: Editora Unesp, 2006.'
} 
de fato, considerado o problema muito cuidadosamente, quando diziam que essa objeção não falava contra eles. Por sua vez, isso nos leva a suspeitar que a posição dos céticos seja mais complicada do que a objeção a considerou, que a objeção de algum modo ignorou algum aspecto crucial de sua posição. (Frede, op. cit. Grifo nosso).

Então, se, em sua crítica anticética, os dogmáticos deixam algo escapar, porque não percebem que a postura cética não é tão tosca como inicialmente supunham, por seu turno, os intérpretes devem "levar a sério os protestos céticos e tentar entender como eles poderiam pensar que essa objeção de algum modo erra o alvo" (Frede, op. cit.). Para tal, é necessário compreender o escopo e a abrangência da suspensão cética do juízo:

Os objetores afirmam que os céticos, na teoria, suspendem o juízo sobre todas as coisas, mas que, na prática, eles simplesmente não podem evitar fazer todo tipo de julgamentos. Assim, pode argumentar-se contra essa objeção (i) tentando demonstrar que os céticos rejeitam que não se possa evitar suspender o juízo na prática, na vida cotidiana - juízos como 'está muito quente hoje' ou 'este carro está prestes a atropelar-me'. Os céticos poderiam conceder que é extraordinariamente difícil levar-se a tal estado em que já nem mesmo se sente qualquer tentação de ter qualquer ponto de vista, mas insistem que [esse estado é] em princípio, possível e, de fato, é compatível com viver uma vida bem vivida. Ou (ii) pode argumentar-se que os céticos pensavam que mesmo que se suspenda o juízo sobre tudo, pelo menos no sentido em que recomendam que se suspenda o juízo, poder-se-ia ainda ter muitas crenças e pontos de vista, suficientes, de todo modo, para levar a uma vida que valha a pena. (Frede, op. cit. Grifo nosso).

Ora, Frede afirma que o segundo argumento é aquele pelo qual os céticos optaram, mas, considerando que a distinção entre os dois exemplos de possíveis

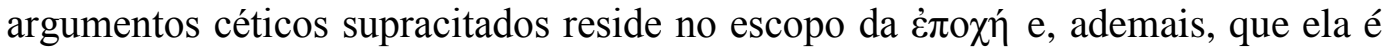
diretamente proporcional aos $\delta o ́ \gamma \mu \alpha \tau \alpha$ - ou seja, quanto mais abrangente a suspensão, mais crenças há a serem eliminadas — devemos partir para um exame mais cuidadoso do significado das palavras dogma, dogmatismo e dogmático, tão recorrentes em Sexto Empírico.

Ressalto que, para Frede, “dogma" refere-se estritamente a crenças teoréticas, ou melhor, a doutrinas filosóficas e científicas e seus conteúdos. Assim, proferimentos como: 'é dia' e 'chove' não seriam dogmas em sentido estrito porque não se relacionam com teorias, são tão-somente proferimentos emitidos a partir da vida comum. O cético de Frede, então, possui crenças, mas ‘crenças comuns’ que não são alvo da suspensão cética de juízo. Frede reduz o 


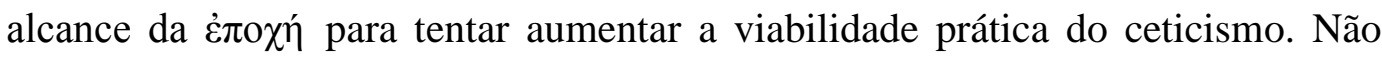
obstante quais sejam as asserções de Frede, agora, em nossa busca por uma

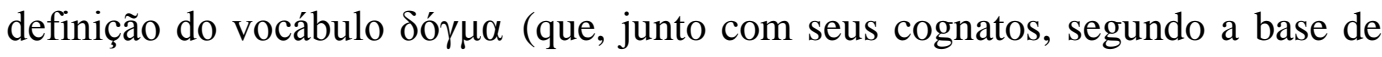
dados 'Diógenes', possui impressionantes onze mil e noventa e uma ocorrências), seguiremos a argumentação de Barnes (op. cit.), para podermos atestar se

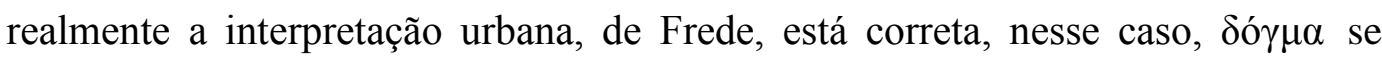
referirá exclusivamente a asserções teoréticas.

De acordo com Barnes (op. cit.):

O substantivo $\delta$ ó $\gamma \mu \alpha$ aparece primeiro, no que do grego chegou até nós, em torno do quinto século. Sua sintaxe e seu sentido não são obscuros. Sintaticamente,

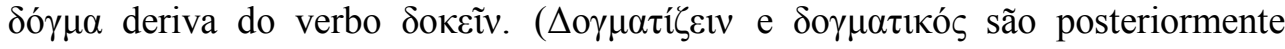
formados a partir de $\delta$ ó $\gamma \mu \alpha)$.

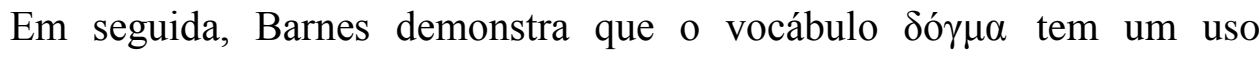
político, notadamente ateniense, com diversas ocorrências relacionadas a decretos oficiais e resoluções das assembleias, e, mesmo em suas ocorrências no corpus platonicus, onde provavelmente se dão os primeiros usos filosóficos da palavra, o significado político é proeminente, com a notável exceção de Teet. 157D2, em que Sócrates afirma que maieuticamente pretende trazer à luz os $\delta$ ó $\mu \alpha \tau \alpha$ de

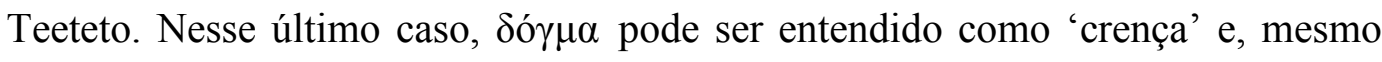
considerando as mudanças que a semântica do vocábulo pode ter sofrido no longo hiato que separa Platão de Sexto, 'crença' persiste como o significado mais comum.

Por outro lado, na maioria dos casos em Platão (Leis 791D5, 798E2, 900B4; Phlb.41B5; Tim. 48D6, 55D1; Sof. 265C5) e também em Aristóteles

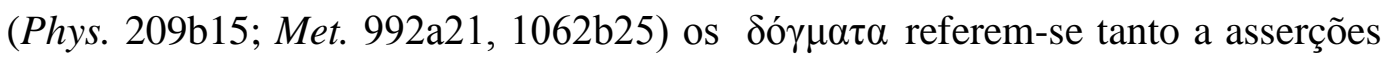
filosóficas quanto a decretos políticos. Do ponto de vista do epicurismo, a começar por Epicuro, que parece ser pioneiro no uso filosófico do verbo

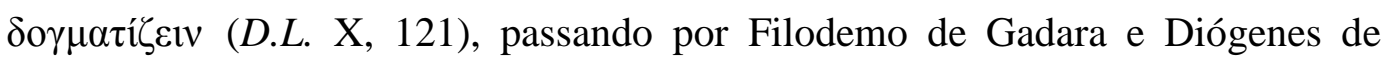

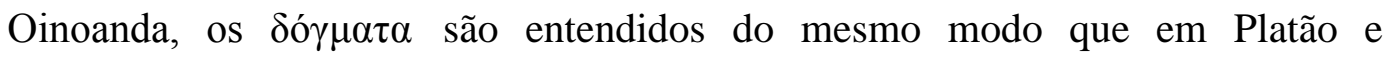
Aristóteles. Agora, o primeiro pensador a usar largamente o vocábulo é Filo de Alexandria, para referir-se tanto a teorias filosóficas quanto a crenças religiosas. Plutarco, em Moralia, além de utilizar o vocábulo exclusivamente para referir-se a asserções filosóficas, retoma o uso político recorrente no corpus platonicus. 


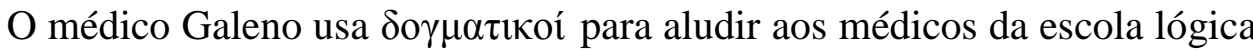
(ou racionalista), que pensavam que as curas para as doenças poderiam ser encontradas a partir da análise e construção de teorias $(\delta o ́ \gamma \mu \alpha \tau \alpha)$ sobre a "interna estrutura dos corpos, ou a tipologia das doenças, doutrinas sobre a natureza da causalidade ou a relação da percepção com o conhecimento" (Barnes, op. cit.). A

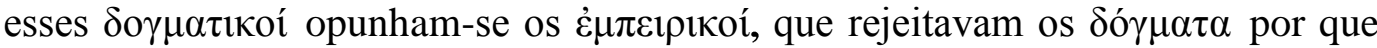
pensavam que o conhecimento (aceito, portanto) deveria residir nas experiências, guias exclusivos para a administração de remédios e diagnósticos de doenças. Nesse âmbito médico, retratado por Galeno, que era "especialmente próximo tanto na data quanto aos interesses, a Sexto" (Barnes, op. cit.), claramente é possível não ter $\delta o ́ \gamma \mu \alpha \tau \alpha$ (estritamente teoréticos) e ainda ter crenças (cotidianas), imunes às reflexões e asserções filosóficas e científicas, aparentemente endossando a interpretação urbana da filosofia sextiana.

Contudo, se olharmos para os estoicismos de Epicteto e de Marco Aurélio, que são fontes importantes e em língua grega para a compreensão da recepção e contundência da Stoá na Roma imperial, bem como para Sêneca e seu decretum (o equivalente latino de $\delta o ́ \gamma \mu \alpha$ ), veremos que a aplicação do termo $\delta o ́ \gamma \mu \alpha$ não se restringe a asserções filosóficas ou científicas:

Nunca $\left(M \eta \delta \varepsilon ́ \pi 0 \tau^{\prime}\right)$ elogie nem culpe um homem por causa das coisas que são

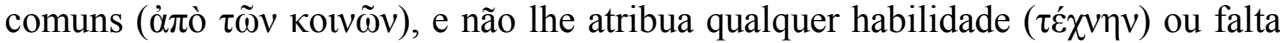
de habilidade ( $\dot{\alpha} \tau \varepsilon \chi v i ́ \alpha v)$, e, assim, você estará livre da temeridade e da maldade.

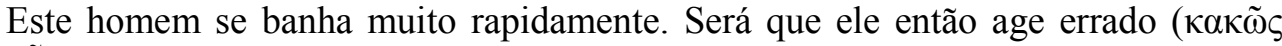

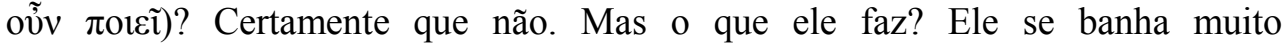
rapidamente. Todas as coisas são, então, bem feitas? De modo nenhum: mas os

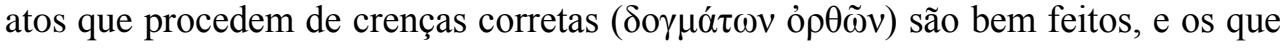

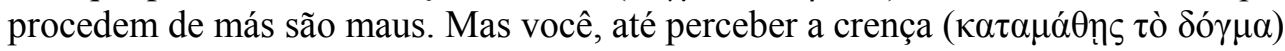
a partir da qual o homem faz cada coisa, nem louve nem culpe o ato. Mas a crença

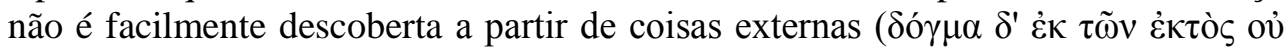

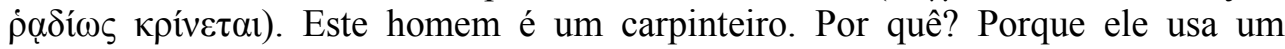
machado. Qual é então o problema? Este homem é um músico, porque ele canta. E o que isso significa? Este homem é um filósofo. Porque ele usa uma capa e cabelo comprido. E o que um malabarista veste? Por isso, se um homem vê qualquer filósofo atuando indecentemente, imediatamente ele diz: "veja o que o filósofo está fazendo"; mas ele deve, por causa do comportamento indecente do homem, dizer que ele não é um filósofo. Porque, se é a ideia preconcebida ( $\pi \rho o ́ \lambda \eta \psi 1 \varsigma)$ de um filósofo e o que ele professa, vestir um casaco e um cabelo longo, os homens diriam "bom"; mas se o que ele professa é, antes, que se deve manter-se livre de falhas, por que nós não, de fato, tendo em vista que ele não faz boas suas profissões, tiramos-lhe o nome de filósofo? Pois isso [é o que] fazemos no caso de todas as outras artes. (Diss. 4.8.1-7). 


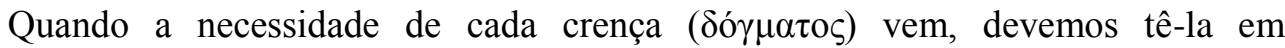
prontidão: na ocasião do café da manhã, essas [crenças] se relacionam com o café da manhã; no banho, aquelas que concernem ao banho; na cama, aquelas que concernem à cama. (Diss. 3.10.1).

Agora, se considerarmos que os principais adversários de Sexto Empírico eram os estoicos e que uma grande parte da argumentação sextiana é conduzida dialeticamente com a filosofia da Stoá, não devemos descartar que Sexto estivesse considerando o uso estoico dos $\delta$ ó $\gamma \mu \alpha \tau \alpha$, necessários para o desempenho das

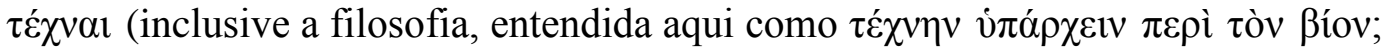
ver: Adv. Eth. 170) e para ações corriqueiras como banho, alimentação e descanso.

Portanto, voltando a Frede, podemos criticar sua interpretação urbana de acordo com os seguintes argumentos:

1- Frede parte da asserção de que, apesar de pretender suspender o juízo sobre tudo, o cético não pode evitar conhecer muitas coisas. Mas, dizer

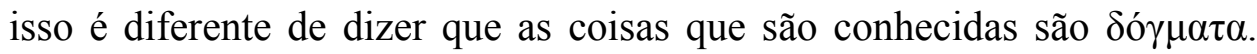
Além disso, se o conhecimento pretende sempre ser da verdade (ou da mentira), por outro lado, se o cético conhece algumas coisas, é o tipo de conhecimento provisório e instrumental para a ação no momento necessário (P.H. I, 16-18, 21-25).

2- Ainda, segundo Frede, os dogmáticos, ao acusarem o ceticismo de levar a uma vida que não pode ser vivida, parecem ter errado o ponto porque imaginaram que o cético abdicaria de todas as crenças. Por outro lado, ele próprio também ignorou um aspecto crucial da discussão, a definição do proferimento cético como um mero relato das aparências, sem compromissos onto/epistemológicos (P.H. I, 187-210), o que o levou ao

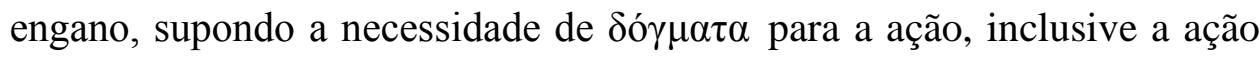
de conhecer.

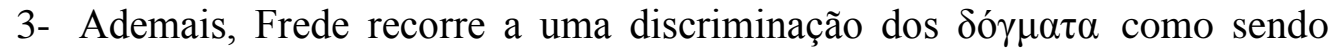
exclusivamente asserções científicas e filosóficas. Mas, como vimos em

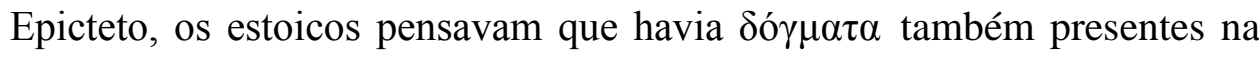
vida comum, necessários tanto para as ações ordinárias quanto para aquelas definidas como corretas e louváveis, não devemos então descartar 
a possibilidade de Sexto estar considerando essa acepção estoica do conceito.

4- Finalmente, devemos ressaltar que os argumentos suspensivos dos tropos (notadamente os dez de Enesidemo e os cinco de Agripa) não incidem tãosomente sobre asserções científicas e filosóficas, mas também sobre asserções presentes na vida comum (P.H. I, 31-178).

Ora, além das críticas supracitadas, segundo Burnyeat (in: ' $O$ cético em seu lugar e tempo'), de acordo com Frede, se o objetivo do ceticismo de Sexto Empírico é a cura do dogmatismo pelo discurso, fazendo com que ao final dessa terapia o paciente se torne um homem comum — nessa instância a teorética filosófica não teria mais cabimento porque simplesmente não se aplicaria mais, uma vez que seu objeto é estritamente teórico —; por seu turno, essa é uma via de mão dupla, e os problemas da vida cotidiana, bem como as soluções dela oriundas, não se relacionam minimamente com a teorética filosófica. E o homem que antes pretendia a felicidade, que a examinou e a perseguiu decepcionou-se, deparou-se com inúmeras aporias, suspendeu o juízo e atingiu a quietude, esse homem, agora livre das crenças teóricas, se tornaria um homem comum e se refugiaria em uma instância em que a teorética filosófica não lhe atingiria: ele estaria insulado.

Mas, se o insulamento consiste no ato de provisoriamente isolar-se do mundo comum quando pensador teorético e também, ao contrário, igualmente provisoriamente, isolar-se do mundo teorético quando ativo na instância da vida ordinária, então, com essa característica dominante, o insulamento começaria verdadeiramente a surgir somente no contexto da filosofia Moderna, por conseguinte, a interpretação de Frede é anacrônica.

Apesar de Burnyeat (op. cit.) ter introduzido a noção de insulamento partindo da defesa de Thompson Clarke ${ }^{161}$ de que os juízos e conhecimentos afirmados e feitos na vida comum são imunes à dúvida filosófica (argumento comparável ao "eis aqui uma mão", de G. E. Moore, contra as dúvidas sobre a existência do mundo externo), por outro lado, também na filosofia francesa do séc. XX houve uma discussão acerca da mudança de perspectiva quanto às

\footnotetext{
161 'The Legacy of Skepticism'. In: 'The Journal of Philosophy', volume 69, número 20, 09
} de novembro de 1972. 
filosofias Helenísticas em sua revisão Moderna - a partir de sua redescoberta que começa com as migrações dos sábios e bibliotecários bizantinos para os nascentes burgos europeus ocidentais no séc. XII -, que fez com que os argumentos dos céticos, mas também dos estoicos, epicuristas e cínicos, não

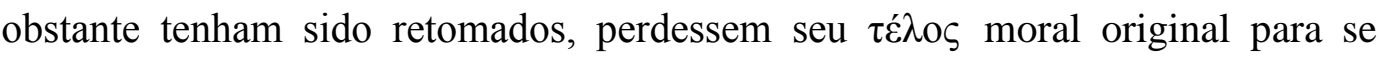
tornarem teses epistemológicas:

\begin{abstract}
A razão mais séria, parece-me, pela qual o lugar ocupado por este princípio [moral, do cuidado de si] durante quase um milênio na cultura antiga foi sendo apagado, pois bem, eu chamaria - com uma expressão que reconheço ser ruim, aparecendo aqui a título puramente convencional - de "momento cartesiano" (...) Primeiro, o momento cartesiano requalificou filosoficamente o gnôthi seautón (conhece-te a ti mesmo). Com efeito, e nisto as coisas são mais simples, o procedimento cartesiano, que muito explicitamente se lê nas Meditações, instaurou a evidência na origem, no ponto de partida do procedimento filosófico (...) (FOUCAULT, M. A Hermenêutica do Sujeito, pág. 18. São Paulo: Martins Fontes, 2004).
\end{abstract}

Por seu turno, Pierre Hadot afirma que o esquecimento e a extinção do entendimento de que a finalidade das filosofias Antigas consistia principalmente em "cuidar de si" começou na Idade Média. Segundo ele, os escolásticos teriam depreciado a filosofia em favor da teologia, fazendo com que a primeira fosse uma ferramenta para demonstrar e provar as verdades da moral cristã, propiciando uma supervalorização da lógica e da epistemologia ${ }^{162}$.

Desse modo, o estoicismo e o epicurismo - que, segundo Sexto ( $A d v$. Eth. 168), eram técnicas de vida - bem como o próprio pirronismo - que, embora não fosse uma técnica dogmática, era um modo de conduta alinhado com a vida ordinária (por exemplo: Adv. Eth. 166) - foram desapropriados de sua

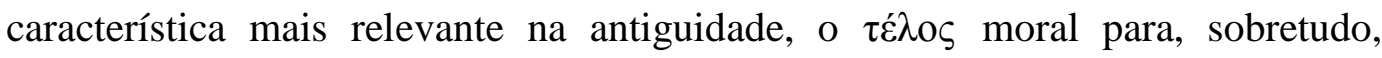
salientar questões sobre o conhecimento científico, como a legitimidade de pretendê-lo, sua possibilidade e a determinação do critério de verdade, devido ao contexto histórico de "um mundo virado de ponta cabeça", o mundo Moderno, que tem como principais elementos constitutivos o Humanismo Renascentista, a Reforma Protestante, a Descoberta do Novo Mundo e a Revolução Científica ${ }^{163}$.

162 Ver: 'HADOT, Pierre. Exercices Spirituels et Philosophie Antique. Éditions Albin Michel, Paris: 1993.'

163 Ver: 'SOUZA FILHO, D. M. A Crise de Paradigmas e O Surgimento da Modernidade'. In: Zaia Brandão. (Org.). 'A Crise dos Paradigmas e a Educação'. São Paulo: Cortez, 1994'; e: 'O impacto do descobrimento do Brasil no pensamento Moderno. In: Rocha, Everardo. (Org.). Cultura brasileira: reflexões, análises e perspectivas. Rio de Janeiro: Desiderata, 2007’. 
Mas, voltando ao insulamento, aqueles que insistem em vê-lo já em Sexto Empírico e que, portanto, mesmo indiretamente aderem ao 'urbanismo' de Frede, apontam para P.H. I, 13; 21-22, respectivamente:

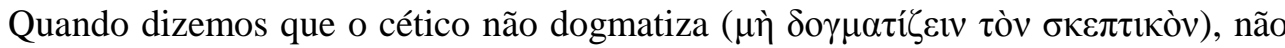
usamos o termo 'dogma' (

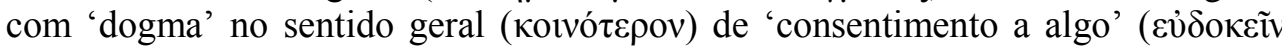
$\tau \imath v \iota \pi \rho \alpha ́ \gamma \mu \alpha \tau \iota$ ) (pois o cético, às impressões coercitivas [originadas nas]

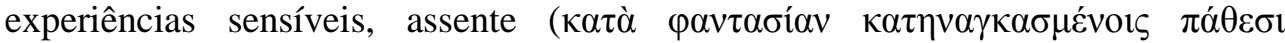

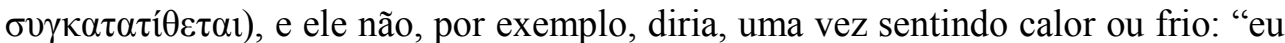

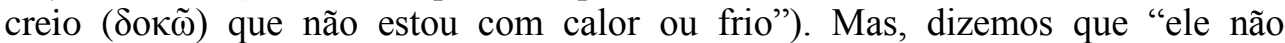

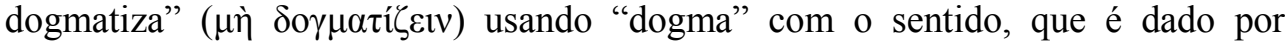
alguns, de "assentimento a alguns dos objetos não evidentes da investigação

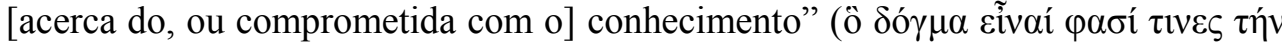

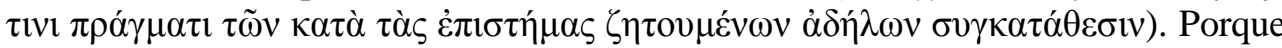
os pirrônicos não assentem ao que é não evidente.

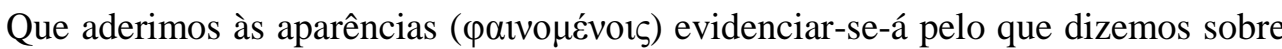
o critério da conduta cética ( $\sigma \kappa \varepsilon \pi \tau \iota \kappa \tilde{\Upsilon} \varsigma ~ \alpha ُ \gamma \omega \gamma \tilde{\eta} \varsigma)$. A palavra "critério" é usada em dois sentidos: no primeiro ela significa "o padrão regulador das crenças na realidade ou na não realidade," (e discutiremos isso na nossa refutação); no outro

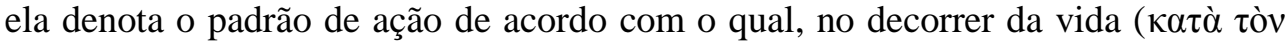
Bíov), agimos de determinadas formas e abstemo-nos de agir de outras; e do último que estamos falando agora. O critério, então, da conduta cética é, dizemos, a

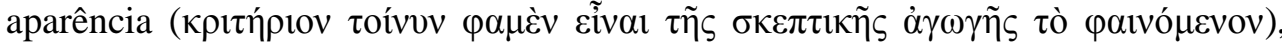
implicitamente significando com isso as impressões ( $\varphi \alpha v \tau \alpha \sigma i ́ \alpha v)$. Considerando que elas dependem de sentimentos passivos e involuntários que não estão sob

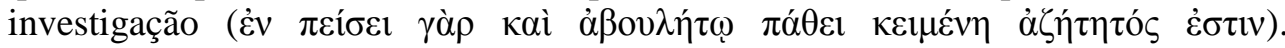
Consequentemente, ninguém, suponho eu, disputará ( $\dot{\alpha} \mu \varphi \imath \sigma \beta \eta \tau \eta ́ \sigma \varepsilon \imath)$ se um tal objeto tem esta ou aquela aparência; o ponto sob disputa é se o objeto é em realidade tal como parece ser.

Como resultado, o cético vive uma vida comum, sem sustentar opiniões $(\dot{\alpha} \delta \mathrm{o} \xi \dot{\alpha} \sigma \tau \omega \varsigma)(P . H . \mathrm{I}, 23)$.

Por outro lado, lembrando a concepção epicteteana de dogma, nós podemos ler P.H. I, 13 diferentemente dos urbanos: o cético não dogmatiza porque não entende dogma como entendem 'alguns' (leia-se: os estoicos), como crenças necessárias para o assentimento a todas as coisas, uma vez que o próprio ato de assentir depende da crença na verdade de um estado de coisas. Por exemplo, para Epicteto, para que alguém se banhe precisa crer que verdadeiramente há uma banheira, ou que banhar-se é verdadeiramente bom. O cético rejeita os dogmas, sejam eles dogmaticamente requeridos pelas ciências, ou pelas filosofias, ou mesmo parcialmente pelo senso comum, ele não crê que tem frio quando não o tem (ou vice-versa), porque ele não está comprometido com o

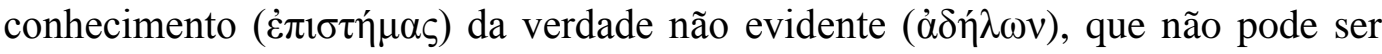


universalmente provada e precisaria, em última instância, de ser crida, porque é sempre, do ponto de vista dogmático, requerida.

Assim, prescindindo da verdade, não porque ela não exista ou porque seja realmente ou em si inatingível — esses são já por si sós juízos de verdade - mas porque, aparentemente, as discrepâncias sobre o assunto 'verdade', agravadas pelo caráter mutuamente excludente, são mais persuasivas do que as concordâncias, o cético pretende viver a vida sem que para agir precise requerer de crenças sobre coisas não evidentes, como fazem as pessoas comuns quase o tempo todo. Desse modo, o cético não endossaria a possível asserção científica de que "um banho faz bem para a saúde", nem a asserção filosófica estoica de que "é preciso uma crença correta sobre o banho para agir corretamente quanto ao ato de banhar-se", tampouco a asserção ordinária de que de "tomar um banho é verdadeiramente bom”. Um pirrônico não precisa crer na verdade do banho, ou construir asserções sobre isso para banhar-se: basta que pareça bom um banho frio em um dia em que se sente calor, pois ele age coagido pelos fenômenos e pelas afecções por eles causados.

Agora, seguindo Sexto em P.H. I, 22, na instância das percepções e aparências, coercitivas, o sujeito estaria recolhido em um tipo de vida que não está aberto a questionamentos, porque quando, por exemplo, uma folha (a)parece

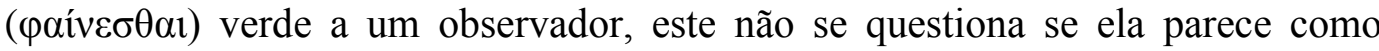
(a)parece, ao invés disso, questionaria se ela é verdadeiramente como (a)parece, algo que o cético não faz, mas que o cientista faz, o filósofo faz, e também o homem ordinário faz, quando assere, por exemplo que "aquele feijão certamente está azedo", e mesmo não tendo quaisquer evidências disso, constrói um pretenso juízo de verdade. E o ceticismo está preparado para ser entendido como uma forma de recolhimento desde a 'Vida de Pirro', haja vista o conceito de $\grave{\alpha} \pi \rho \alpha \gamma \mu$ $\sigma 0 ́ v \eta$ sobre o qual já discorremos, sem que esse recolhimento precise ser o anacrônico insulamento, aquele modo de se isolar provisoriamente na vida ordinária para fugir às próprias questões levantadas pela igualmente provisória vida teorética, o cético "não divide seu pensamento em dois compartimentos separados, um para os dias da semana e o outro para os domingos"164.

164 'CORNFORD, F. M. Antes e Depois de Sócrates. São Paulo: Martins Fontes, 2007', falando sobre Pitágoras e usando-o como exemplo para demonstrar que em toda a filosofia Antiga não há uma única noção de 'filosofia' que não seja uma vivência prática. 


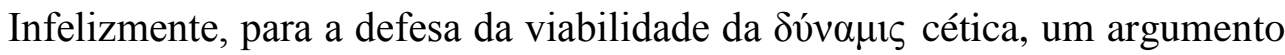
rústico mais cru, como o que aparece acima, não basta, porque um dogmático poderia insistir que quanto maior o escopo da suspensão cética do juízo, maior a vulnerabilidade da vida e, se assim for, como evitar a acusação de $\alpha \operatorname{\pi } \rho \alpha \xi i ́ \alpha$ $(\dot{\alpha} v \varepsilon v \varepsilon \rho \gamma \eta \sigma i ́ \alpha)$ ?

Ou seja, se de fato a interpretação de Frede conta com o dispositivo anacrônico do insulamento, por outro lado, a interpretação de Burnyeat, cronologicamente impecável, abre o flanco para as críticas anticéticas.

Então, diante da equipolência das teses de Frede e Burnyeat, que são tão persuasivas quanto dissuasivas, não nos sentimos confortáveis para optar por uma ou outra. Ao invés disso, reconhecemos nossa aporia e somos coagidos a reter o assentimento. Mas, se isso ocorre, por outro lado, mesmo tendo suspendido o juízo, nossa vida não fora comprometida em nenhum aspecto, inclusive, podemos continuar a escrever e dar seguimento a nossa tese, porque somos igualmente coagidos pelas afecções e, de acordo com elas, há uma interpretação que me parece possível, uma terceira via interpretativa, a meio caminho do rústico e do urbano que será nosso objeto de agora em diante.

\subsection{A "via média"}

A via média é um mecanismo eclético - que não se pretende como a interpretação verdadeira ou definitiva - para elucidar o pirronismo de Sexto e que opera basicamente do seguinte modo:

1- concordando com Frede:

a- logo, o ceticismo conduz à vida comum;

b- e essa vida está imune à teorética filosófica.

2- Concordando com Burnyeat:

a- não há insulamento na filosofia antiga;

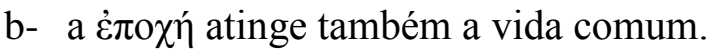

Voltando à definição de dogma que apresentamos mais acima - que é proporcional à suspensão do juízo, uma vez que quanto mais dogmas houver, 
maior será a suspensão — o vocábulo se refere tanto a asserções científicas, quanto filosóficas, ou mesmo da vida ordinária. Contudo, se assim é, precisamos tentar entender o que pode haver em comum entre esses três tipos de asserções que faz com que elas sejam todas incluídas no conjunto 'dogmas': o compromisso com a verdade, conforme argumentamos. Por sua vez, isso nos leva a uma definição de verdade que se encaixa com as três instâncias do dogma, para tal, usaremos Landim ${ }^{165}$ :

\section{Proposição 1}

Em certos casos, usar uma frase constatativa (...) equivale a fazer uma asserção. (...) Proposição 2

Realizar uma asserção significa afirmar que o asserido, o conteúdo proposicional é verdadeiro. (...)

Proposição 3

Afirmar que o conteúdo proposicional é verdadeiro significa tomar uma posição, isto é, significa comprometer-se com o asserido (...)

Proposição 4

Pretender que existem razões que justificam a correção da asserção significa dizer que as condições de verdade - as cláusulas que indicam em que circunstância a asserção é verdadeira - estão satisfeitas.

Proposição 5

Dizer que as condições de verdade estão satisfeitas supõe ao menos duas coisas: que se conheça quais são estas condições de verdade e que se tenha critérios que permitam indicar a sua satisfação. (...)

Proposição 6

O ouvinte interpelado pelo falante compreende a asserção se (I) compreender o que está sendo asserido, o conteúdo proposicional. (II) e compreende a força do ato de asserir. (...)

Proposição 7

A compreensão pelo ouvinte da força do ato assertórico é a compreensão daquilo que exprime o operador "é verdade que..."; significa portanto a compreensão do compromisso e da interpelação do falante.(...)

Proposição 8

A possibilidade de resposta linguística do ouvinte ao ato do falante faz parte do sentido da asserção.

Em suma, o caráter assertórico das proposições em que há dogma se evidencia pelo compromisso da asserção com a necessidade de constatar uma verdade; por sua vez, esse compromisso faz com que o emissor tome uma posição, comprometendo-se, agora, com a própria asserção; defender uma asserção, ou tomar uma posição em seu favor, significa asserir que estão satisfeitas as cláusulas que indicam que ela constata a verdade; para tal, são precisos critérios ou

\footnotetext{
${ }^{165}$ Ver: 'LANDIM FILHO, R. F. Significado e verdade. In: Souza Filho, D. M. (org.). Significado,
} verdade e ação. Niterói: EdUFF,1986’. 
condições de verdade; para que o que está em jogo no ato de asserir seja devidamente compreendido, o ouvinte deve compreender o conteúdo da asserção e sua força ilocucionária; isso envolve a compreensão do operador "é verdade que..." e do compromisso do falante; o ouvinte, assim, responde ao sentido da asserção.

Ora, o cético de Sexto (1) não se compromete com a verdade, tampouco a rejeita, não construindo uma asserção dogmática negativa, o que ele faz é

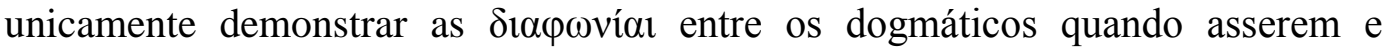
definem uma verdade ( $A d v$. Log. I, 38-46); (2) ele também não se compromete com asserções, de fato, evita ao máximo negar ou afirmar peremptoriamente a verdade de qualquer coisa, inclusive se "é dia" ou "não é dia" (P.H. I, 192-194); (3) o cético, por prescindir da verdade, não busca cláusulas, critérios ou condições para ela, somente investiga os critérios dogmáticos/assertóricos (P.H. I, 21-23; $A d v$. Log. I, 27-38, 46-446); (4) por outro lado, para tal, o cético compreende, sim, o que está em jogo no ato de asserir, e também a força ilocucionária das asserções, e justamente por isso não assere, por que não adere ao operador "é verdade que...”; (5) então, a resposta cética ao sentido do dogma/asserção não é outro dogma/asserção, mas um ato de fala outro, não constatativo.

Assim, se os $\delta$ ó $\gamma \mu \alpha \tau \alpha$ são asserções (ou constatativos) presentes mesmo no

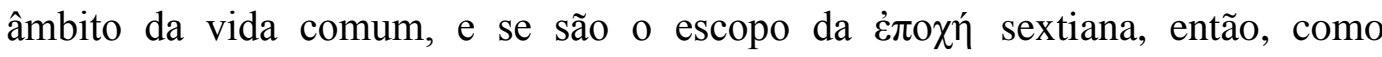
Burnyeat (op. cit.) havia pensado, a suspensão de juízo atinge a vida comum, logo, não há o anacrônico insulamento em Sexto, nossa interpretação é cronologicamente impecável ${ }^{166}$. E, por outro lado, como resultado da depuração da linguagem da contaminação dogmática, que crê que para agir é preciso,

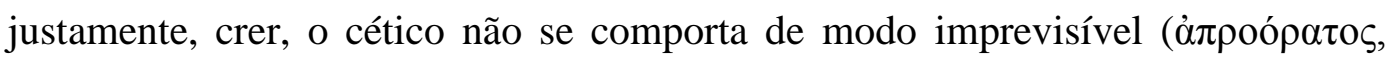
contra os detratores de Pirro em sua ' $V i d a$ '), não pretende viver uma vida impossível na prática ( $\dot{\alpha} \pi \rho \alpha \xi i ́ \alpha$ ou $\alpha \dot{v} \varepsilon v \varepsilon \rho \gamma \eta \sigma i ́ \alpha$, contra os estoicos), reconhece sua

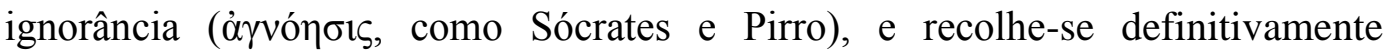

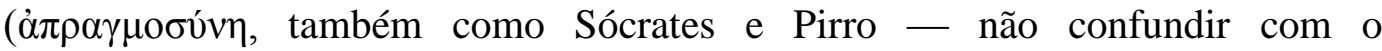
insulamento) na vida comum, e agindo conforme as aparências

\footnotetext{
${ }^{166}$ Para mantermos uma interpretação cronologicamente perfeita, devemos ressaltar que tampouco o emprego da distinção aqui entre o discurso do cético e o do dogmático, através da teoria dos atos de fala, é anacrônica, uma vez que os Antigos discriminavam diferentes 'usos da linguagem', ver: BARNES, J. op. cit.
} 
vivemos de acordo com as regras normais da vida, sem dogmatizar, tendo em vista que não podemos permanecer totalmente inativos. E isso significa que essa regulação da vida é quádrupla, e que uma parte dela reside no guiamento pela natureza, outra no constrangimento das paixões, outra na tradição das leis e costumes, outra na instrução das artes. O guiamento da natureza é a maneira pela qual somos naturalmente capazes de sensações e pensamentos; o constrangimento das paixões faz com que a fome nos leve a comer e a sede a beber; a tradição dos costumes e leis é a maneira pela qual consideramos a piedade na conduta da vida como boa, mas a impiedade como um mal; a instrução das artes é a maneira de não nos fazermos inativos nas artes que adotamos. Mas fazemos todos estes proferimentos não dogmaticamente. (P.H. I, 23-25).

Voltando novamente aos estoicos, propusemos muito anteriormente, quando falamos sobre sua ética, que seu sistema moral deveria ser compreendido segundo o conceito kantiano de máximas $(\dot{\alpha} \pi \circ \varphi \theta \dot{\varepsilon} \gamma \mu \alpha \tau \alpha)$. Contudo, se o cético rejeita os $\delta o ́ \gamma \mu \alpha \tau \alpha$ estoicos, que compõem a totalidade da filosofia da Stoá, então ele rejeita também as máximas estoicas, mas não rejeita todas as máximas que existem. $\mathrm{O}$ cético não se compromete com asserções sobre a verdade ou falsidade, no âmbito do conhecimento, como já argumentamos, tampouco se compromete com asserções sobre o certo ou o errado, os estoicos, por seu turno, pretendem erigir um critério assertórico tanto para a ação quanto para o conhecimento, suas

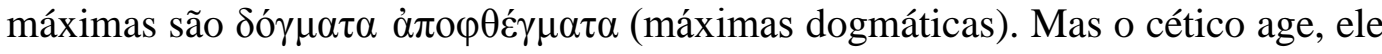
não pode viver inativo - uma vez que isso seria retornar à $\alpha \ln \rho \alpha \xi i ́ \alpha$ ou à

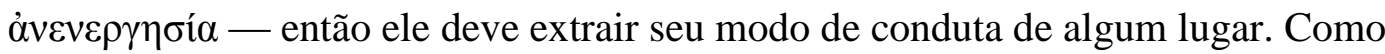
todos são coagidos pela natureza, ele também o é, isso basta para que seja capaz de pensar e sentir; as afecções não são objeto de questionamento e fazem com que ele preserve sua vida, comendo e bebendo quando sente necessidade; aderir às leis e costumes provê um conjunto de máximas não teóricas e não crentes ( $\dot{\alpha} \delta$ ò $\xi \alpha \sigma \tau o$ 1

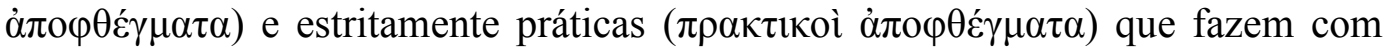
que ele possa discernir entre o que é considerado bom ou mau por sua cultura ou meio específico, voltando à acepção mais básica do vocábulo ع̋ $\theta$ os (LSJ: costume, hábito), o cético adere a uma espécie de máxima extraída da vida comum: $\kappa \alpha \tau \grave{\alpha}$

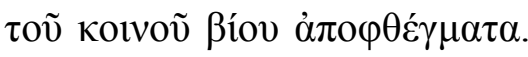

Agora, se o proferimento do cético sextiano não é um constatativo, porque não se compromete com a verdade, isso significa que ele seja um performativo? Perguntando de outra forma: em que sentido é possível distinguir entre a função performativa e a função constatativa da linguagem, não somente no âmbito do 
proferimento do cético, mas dos proferimentos em geral? Elucidemos melhor essas questões.

Inicialmente, J. Austin supôs que haveria dois tipos de proferimentos: (1) os constatativos - que constatam fatos, elucidam estados de coisas e podem ser verdadeiros ou falsos - e (2) os performativos - caracterizados pelo fato de que o próprio proferimento é a realização de um ato, como: batizar, prometer ou apostar.

Além disso, nos performativos há a assimetria entre a primeira e a terceira pessoa, assim, quando digo: "ele promete", isso é um constatativo, mas quando digo: "eu prometo", eis um performativo. Então, performativos explicitam ações expressas por verbos conjugados na primeira pessoa do singular do presente do indicativo ativo, mas não todos os verbos. Se digo, portanto, "consulto fichamentos ao redigir a tese", dizer que "consulto" não se confunde com o ato de consultar, posso mentir, logo, se esse proferimento pode submeter-se a uma avaliação sobre sua verdade ou falsidade, de acordo com o estado de coisas por ele expresso, então, dizer: "consulto fichamentos ao redigir a tese" é um constatativo, apesar do verbo "consultar" aparecer na primeira pessoa do singular do presente do indicativo ativo. Por outro lado, quando digo: "aposto que consulto fichamentos ao redigir a tese", o ato mesmo de apostar é um proferimento, ou seja, performativos são proferimentos que equivalem à realização de atos, não são verdadeiros ou falsos, mas felizes ou infelizes, de acordo com certas condições: a sinceridade do proferidor, por exemplo. Contudo, "sinceridade" pode ser uma armadilha aqui. Imaginemos que alguém aposta que consulta fichamentos ao redigir sua tese, mas mente, apesar disso, de não ter sido sincero quanto ao teor de sua aposta, ainda assim praticou o ato de apostar e deve arcar com as consequências das normas inerentes à aposta, isso significa que os performativos não são expressões de atos interiores, e a falsidade do teor da aposta não a anula, uma vez que o ato de apostar envolve um compromisso definido por uma norma.

Assim, os proferimentos performativos definem uma dimensão essencialmente pública e dialógica da linguagem, pois servem para executar atos que se definem: $1^{\circ}$ ) pela relação palavra/norma social, $2^{\circ}$ ) pela relação palavra/interação. Os proferimentos performativos servem para estabelecer uma forma de comunicação ou de interação do locutor com seu interlocutor por meio da invocação de uma norma ou convenção social.

Podemos entender agora também todas as implicações da noção de ato de fala. Os proferimentos performativos são atos linguísticos não apenas no sentido 
corriqueiro de ações decorrentes da espontaneidade de um sujeito, mas também no sentido pregnante de um ato tendo um efeito convencional (por exemplo, um efeito legal, nos atos jurídicos, como jurar num tribunal, dizer "Sim" na cerimônia do casamento, ou assinar uma escritura de compra e venda, etc., ou um efeito simplesmente sancionado por uma norma, como dar a permissão, jurar, prometer, etc., numa conversa informal). (ALMEIDA, G. A. Aspectos da filosofia da linguagem. In: MARCONDES de Souza Filho, D. (org.). Significado, verdade e ação. Niterói: EdUFF,1986’. Grifo nosso).

De posse das definições expressas logo acima dos proferimentos constatativo e performativo, poderíamos, além de rejeitar que o proferimento do cético seja um constatativo, imaginá-lo como performativo, afinal de contas, (1) em todo P.H. Sexto Empírico fala em primeira pessoa quando se refere à sua

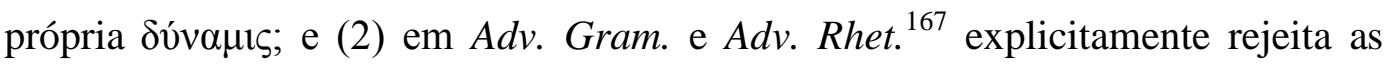
técnicas dogmáticas de discurso em nome do uso comum da linguagem, pautado por um sentido abrangente de normas (máximas da vida comum, vide o "кoเvoṽ

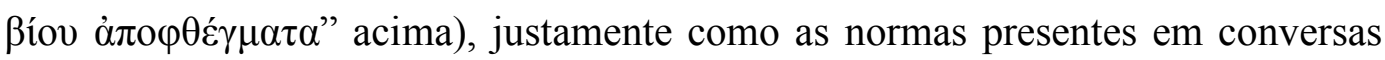
informais, preservando o caráter convencional da ação linguística do cético, bem como de todas as outras ações, contra a acusação de $\alpha$ đ $\rho \alpha \xi i ́ \alpha$.

Mas, apesar dessa interpretação estar totalmente de acordo com o que já

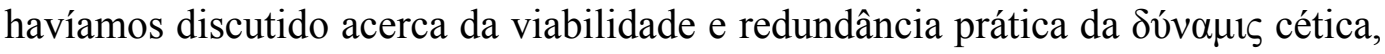
por outro lado, há algumas contradições. Primeiramente, mesmo não havendo nas filosofias antigas, de um modo geral, a noção de indivíduo envolvida na racionalidade Moderna ${ }^{168}$, (1) Sexto Epírico afirma que o proferimento cético é a

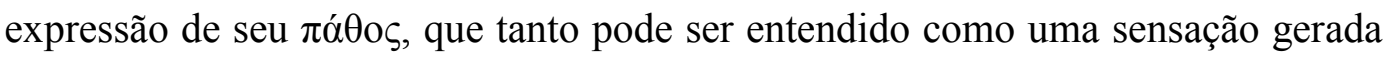
pelos sentidos, quanto o estado mental surgido após as afecções (P.H. I, 187) ${ }^{169}$, e (2), de um modo geral, se todos os proferimentos céticos são a expressão de seu

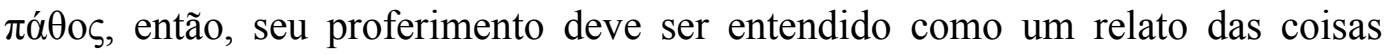
como ocorrem no presente momento (P.H. I, 4). Assim, se realmente o cético externaliza através do discurso seus atos interiores, então seu proferimento não é um performativo; e também, se seu discurso é um relato pessoal, por mais que isso reduza a força assertórica do seu proferimento e por mais que o relato seja um tipo de performativo - porque o ato de relatar só se dá quando se relata algo, por

\footnotetext{
${ }^{167} A d v$. Rhet será objeto de uma análise mais detalhada adiante.

168 Ver: 'BICCA, L. 'Racionalidade Moderna e subjetividade'; 'A subjetividade Moderna: impasses e perspectivas'; 'Subjetividade, existência e auto-realização'. In: BICCA, L. Racionalidade Moderna e subjetividade. São Paulo: Loyola, 1997.'
} 
outro lado - ele também é um constatativo, na medida em que o locutor faz constatar a outrem como as coisas lhe (a)parecem ${ }^{170}$.

Ora, a "zona de penumbra" aqui, quanto a qual categoria pertence o proferimento cético, se é um constatativo ou um performativo, não se deve a um fracasso conceitual do ceticismo, mas a uma limitação da primeira formulação da teoria dos atos de fala, que o próprio J. Austin veio a se dar conta - porque os constativos também têm um aspecto performativo - isso fez com que fosse elaborada outra forma de discriminar entre os fatos linguísticos que não se fundamentasse em tipos mutuamente excludentes de proferimentos, mas em diferentes níveis estruturais dos próprios fatos. Dessa forma,

[Austin] propõe assim a distinção de pelo menos três atos que se podem realizar ao mesmo tempo num mesmo proferimento:

$\left.1^{\circ}\right) \mathrm{O}$ ato locucionário, que consiste no ato de dizer certas palavras pertencentes a uma determinada língua e assim dotadas de um significado convencional, exibindo ademais uma determinada estrutura sintática e pronunciadas num certo tom de voz e entonação, e veiculando um sentido e uma referência de acordo com o contexto e a intenção do locutor. (...)

$\left.2^{\circ}\right) \mathrm{O}$ ato ilocucionário, que consiste no ato que se realiza ao se realizar $\mathrm{o}$ ato locucionário, isto é, no ato de proferir uma palavra ou frase. Os atos ilocucionários podem ser explicitados através de um verbo performativo, que torna clara a força ilocucionária do proferimento, ou seja, a que equivale proferir tais palavras. Por isso mesmo, todos os proferimentos performativos são exemplos de atos ilocucionários. E como se mostrou que os proferimentos constatativos também têm uma dimensão performativa, também eles são exemplos de atos ilocucionários. Assim, numa constatação, por exemplo, podemos distinguir a enunciação de uma frase do ato de constatar propriamente dito.

$3^{\circ}$ ) Os atos perlocucionários que consistem na obtenção de um determinado efeito no interlocutor através da execução de um ato locucionário ou ilocucionário, não em virtude de uma convenção que estabeleça uma equivalência (dizer $\mathrm{X}$ equivale a fazer Y), mas em virtude de uma consequência natural, ou causal (dizer X para fazer com que Y). (ALMEIDA, G. A. op. cit.).

Voltando aos céticos e aos dogmáticos, se seus atos locucionários são idênticos - tendo em vista que os sons que proferem pertencem a uma língua com uma estrutura gramatical que determina, mesmo que nem sempre muito precisamente, a organização e a sintaxe das palavras — seus atos ilocucionários

${ }^{169}$ Ver: 'BURNYEAT, M. F. Can the Sceptic Live his Scepticism? In: BARNES, J; SCHOFIELD, M; BURNYEAT, M. (orgs.). Doubt and Dogmatism, Studies in Hellenistic Epistemology. Oxford: Claredon Press, 1980.'

170 'Num primeiro momento da elaboração de sua teoria, Austin supõe que podemos usar as palavras para falar sobre as coisas, isto é, para constatar fatos, anunciar estados de coisas, relatar ocorrências, descrever objetos, expor opiniões, etc.' (ALMEIDA, G. A. op. cit., grifos nossos). Embora, de acordo com nossa argumentação, a linguagem de Sexto seja de um tipo tal que ele não 
não são nem mesmo parecidos: o dogmático assere o que imagina ser a verdade, e também os homens comuns que são contaminados pela pseudo-necessidade de asserir, mas o cético profere um tipo de discurso que é tão-somente o relato das aparências, e assim devem ser entendidos todos os seus proferimentos, eis o sentido da $\alpha \dot{\alpha} \alpha \sigma i ́ \alpha$ cética.

Como resultado, todo o discurso de Sexto Empírico em P.H. deve ser entendido, como ele mesmo expressa logo na abertura de seu livro (em P.H. I, 15), como um ato que tem

a força ilocucionária de advertir-nos sobre a posição que devemos adotar em relação ao texto como um todo, a tudo que se segue, a "nossas proposições futuras" (...) [ele] é o que poderíamos chamar de macro ato de fala (Van Dijk, 1977) que engloba todos os outros e os contextualiza de uma maneira determinada. (MARCONDES de Souza Filho, D. A "Felicidade" do Discurso Cético: o Problema da Auto-refutação do Ceticismo. In: O Que Nos Faz Pensar, n ${ }^{\circ} 8$, 1994').

\subsection{Uma conclusão provisória}

Recapitulemos essa etapa final de nossa argumentação.

Pensávamos que o cético sextiano não suspendia o juízo somente quanto às teorias filosóficas ou científicas, mas também quanto às asserções presentes mesmo na vida comum, e essa amplitude da غ̇ंo $\chi \eta ́$ não faz com que ele incorra em

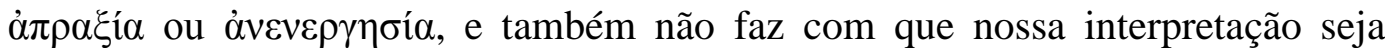
anacrônica. Para tal, precisávamos identificar o que há em comum entre as asserções da vida ordinária e as filosóficas ou científicas que fazem com que

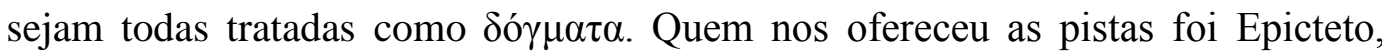
para quem haveria crenças ordinárias, um filósofo particularmente relevante se considerarmos que o principal alvo de Sexto eram os estoicos e sua terminologia e conceituação.

Pudemos propor, assim, uma via interpretativa que escapasse da ỏ̇opía entre as interpretações de Frede e Burnyeat recorrendo à teoria dos atos de fala. Então, o alvo da suspensão cética do juízo são as asserções, porque são mutuamente excludentes e infelizes ao pretenderem, todas, asserir a verdade, 
restam ao cético outras formas não assertóricas de proferimento, ele pode se comunicar, viver uma vida comum e até mesmo ser ativo em uma $\tau \dot{\chi} \chi v \eta$ ao ponto de indicar o ceticismo como a terapia que parece melhor (embora não saiba se realmente é) contra a presunção e a precipitação dogmáticas.

$\mathrm{Na}$ próxima etapa, gostaríamos de verificar a consistência de nossa 'via média' (por falta de nome melhor) utilizando-a como ferramenta para análise de um objeto específico: 'Contra os retóricos', de Sexto Empírico. 


\section{Análise de 'Contra os retóricos'}

\subsection{Esquema geral do argumento de Adv. Rhet.}

Entre as obras de Sexto Empírico, as que chegaram até nós são: ПYPP $\Omega N E I \Omega N$ ҮПОТҮП $\Omega \Sigma \mathrm{E} \Omega \mathrm{N}$ ('Esboços pirrônicos'), composta por três partes, que, grosso modo, oferecem um esboço do que seja o pirronismo; ПРО $\Sigma \Delta$ OГMATIKOY $\Sigma$ ('Contra os dogmáticos'), por sua vez dividido em cinco livros, a saber: 'Contra os lógicos' I e II, 'Contra os físicos' I e II, e 'Contra os éticos', em um único

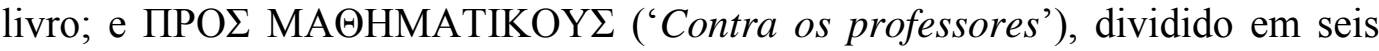
livros: 'Contra os gramáticos', 'Contra os retóricos', 'Contra os geômetras', 'Contra os aritméticos', 'Contra os astrólogos' e 'Contra os músicos'. Além das obras supracitadas, Sexto Empírico teria escrito ainda: IATPIKA ҮПOMNHMATA ('Tratado médico'; ou EMПEIPIKA YПOMNHMATA, 'Tratado empírico') е ПЕРІ ЧҮХН 2 ('Sobre a alma').

De um modo geral, 'Contra os professores' é um ataque às artes, técnicas ou ofícios ( $\tau \dot{\varepsilon} \chi v \alpha 1)$ que começa por uma polêmica contra as artes em geral e prossegue aprofundando a disputa, fazendo-a incidir, depois, sobre cada arte individual. Assim, Sexto Empírico alinha-se primeiramente aos epicuristas ( $A d v$. Gram. 1-7), para quem as artes não poderiam levar à sabedoria ou à perfeição, contudo, a seguir, Sexto alega que essa mesma refutação às artes de molde epicurista é dogmática. O ataque de Sexto, por outro lado, possui a mesma motivação que todos os seus outros ataques às filosofias dogmáticas, a rejeição da presunção inerente à assunção da sabedoria e do conhecimento, as aporias, controvérsias e disputas em torno da verdade e, finalmente, a pretensão de possuir o melhor ou derradeiro critério para o conhecimento dessa verdade, que leva à sabedoria (ou, inversamente, um ataque contra a negação radical da possibilidade do conhecimento, que é uma espécie de dogmatismo negativo).

Assim, em 'Contra os professores', bem como em todas as suas obras, Sexto Empírico usa os argumentos dogmáticos para se refutarem mutuamente, sem comprometer-se com as fundamentações teóricas internas aos sistemas aos 
quais pertencem. Sua leitura é seletiva, mas profunda e selecionada com conhecimento de causa; sua finalidade imediata é fazer emergir aporias que levem o leitor a reter o assentimento quanto às questões em disputa, conduzindo-o por acaso à $\alpha \dot{\tau} \alpha \rho \alpha \xi i ́ \alpha$.

Dessa forma, o argumento de $A d v$. Rhet., um ataque aos que professam a possibilidade de se ensinar essa arte, começa com a busca pela definição da retórica, que se demonstra aporética, porque os próprios filósofos dogmáticos são incapazes de oferecer uma definição unânime para ela (1-10); depois disso, Sexto envereda por definições aristotélicas e platônicas da Retórica (10-20) até chegar à posição acadêmica sobre essa arte, que provisoriamente oferecerá os argumentos necessários à refutação da noção estoica de retórica (20-43). Em seguida, são apresentadas defesas de característica estoica (43-48), de onde se conclui a inconsistência da retórica. Logo após, Sexto envereda por uma análise acurada sobre as próprias partes dessa arte (48-60), culminando com a sua finalidade, onde começam a se desenhar os ataques que serão lançados, agora, aos próprios critérios acadêmico (a que Sexto aderiu anteriormente) e estoico (60-112), para tal o médico cético tem que distinguir entre a linguagem do cético e a linguagem do dogmático (no caso, o professor de retórica), bem como o modo como o cético é ativo nas $\tau \varepsilon ́ \chi v \alpha \iota$ e o modo como o dogmático também o é. Mas, acompanhemos as palavras de Sexto Empírico.

\subsection{Adv. Rhet. passo a passo}

\subsubsection{A busca pela definição de retórica}

$A d v$. Rhet. continua as discussões já inciadas em Adv. Gram., mas Sexto Empírico a considera mais importante, porque as discussões sobre a gramática são mais teóricas, ao passo que a $\tau \dot{\varepsilon} \chi v \eta$ retórica tem sua eficácia testada na prática ${ }^{171}$. Como em todas as suas obras, com a exceção de $P . H$. , as discussões sextianas começam sempre pela tentativa de definir o objeto sob exame, para a retórica ele adota inicialmente uma definição de Platão ${ }^{172}$ que aparece em Gorg., notadamente no passo 453a:

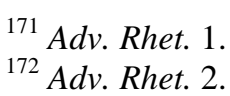


SÓCRATES: Quer parecer-me, Górgias, que explicaste suficientemente o bem que consiste para ti a arte da retórica. Se bem te compreendi, afirmastes ser a retórica a mestra da persuasão, e que todo o seu esforço e exclusiva finalidade visam apenas a esse objetivo. Ou tens mais alguma coisa a acrescentar sobre o poder da retórica, além de levar a persuasão à alma dos ouvintes?

GÓRGIAS: De forma alguma, Sócrates: acho tua definição muito boa. A persuasão é, de fato, a finalidade precípua da retórica.

Contudo, apesar de aparecer em um diálogo de Platão, a definição não é de Platão, mas de Górigias, mas parece que, para Sexto Empírico, se a definição aparece em um diálogo platônico, considerando que não se pode saber ao certo a posição do próprio Platão acerca de qualquer assunto, uma vez que ele não é personagem dos próprios diálogos, basta que Platão seja autor dos diálogos para ser também tratado como autor de quaisquer definições contidas nesses diálogos.

Mas não somente a retórica produz persuasão, a beleza também o faz ${ }^{173}$, logo, a retórica deve ser produtora da persuasão através das palavras ${ }^{174}$, embora

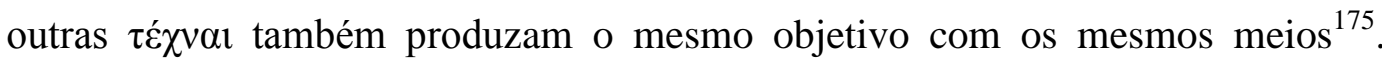
Portanto, o retórico não deve tão-somente suscitar a persuasão através do discurso, mas deve induzir à persuasão ${ }^{176}$, usando o discurso para tal.

Se, assim, o discurso é primordial para o tipo de persuasão induzido pela retórica, então se deve tentar pensar em uma definição de retórica que atente para o tipo ou a qualidade do discurso dos retores, o que leva-nos às definições dos estoicos e de Xenócrates ${ }^{177}$ para a retórica como "a ciência do bom discurso"

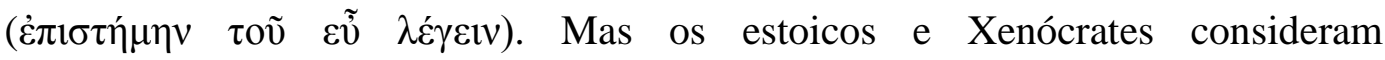

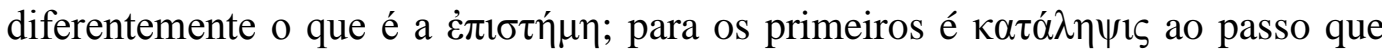
para o segundo é $\tau \varepsilon ́ \chi v \eta$. Além disso, distinguem também entre o discurso dos

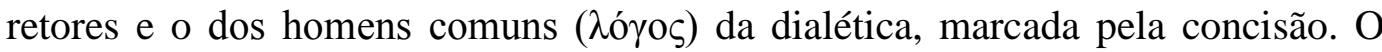
$\lambda$ ó $\gamma$ o $\varsigma$ dos oradores é floreado e adornado através de diversos recursos estilísticos, ao passo que o das pessoas comuns não possui essas características, mas ambos diferem da dialética ${ }^{178}$.

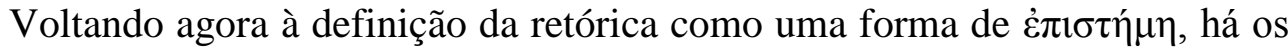

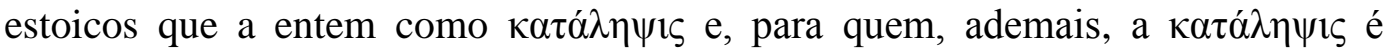

\footnotetext{
${ }^{173}$ Adv. Rhet. 3-4.

${ }^{174}$ Adv. Rhet. 5.

${ }^{175}$ Adv. Rhet. 5.

${ }^{176}$ Adv. Rhet. 5.

${ }^{177}$ Xenócrates viveu no período compreendido em circa 396-314 a.C. e sucedeu Espeusipo como escolarca da academia no período compreendido entre c. 339-314 a.C. Ver: Adv. Rhet. 6.

${ }^{178}$ Adv. Rhet. 6-7.
} 


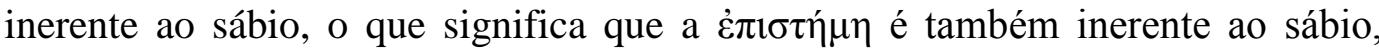
então a ciência do bom discurso da mesma forma também o é. Há também

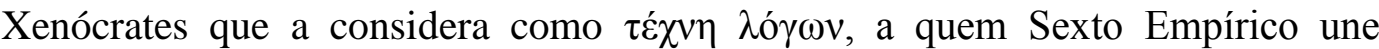
Aristóteles e cita Rhet. $\mathrm{I}^{179}$ ressaltando que há ainda outras definições aristotélicas.

Mas Sexto não pretende discutir as descrições da retórica, seu objetivo é fazer uma refutação que atacará precisamente as definições dela como (1) arte

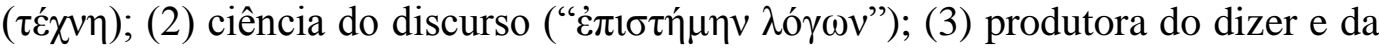

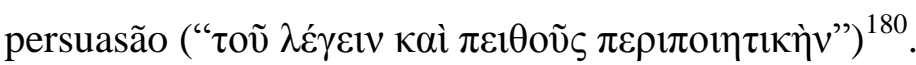

\subsubsection{As refutações às definições disponíveis}

Analisemos as refutações lançadas por Sexto Empírico às três definições

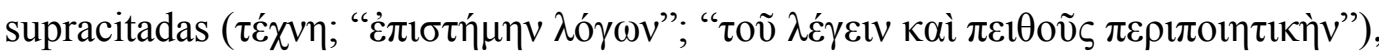
comecemos pela definição de retórica como $\tau \dot{\varepsilon} \chi v \eta$.

\subsubsection{As refutações à definição da retórica como réxvn}

Se a definição da retórica recorre à arte, então deve haver também uma definição de arte, a começar pela definição estoica em que arte é "um sistema composto por apreensões exercidas em conjunto e dirigidas a um fim útil para a vida" (Ad. Rhet. 10). Agora, essa definição estoica de arte, por sua vez, ocorre também em P.H. III, 188, mas relacionada à sua psicologia dogmática e conduzindo a uma aporia:

\footnotetext{
Novamente, os estoicos declaram que os bens da alma são determinadas artes

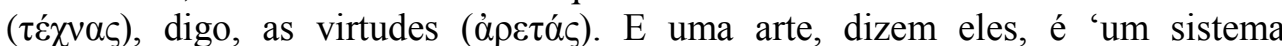

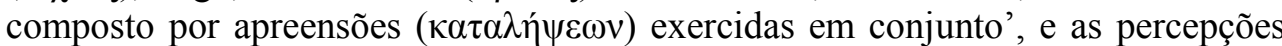

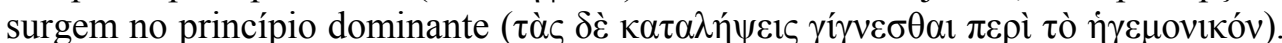
Mas, como tomam lugar no princípio dominante, que, de acordo com eles, é o alento, um depósito de percepções, e tal agregado delas é capaz de produzir arte, é impossível de conceber, dado que cada impressão sucessiva oblitera a anterior, tendo em vista que o alento é fluido, e dele é dito que se move como um todo a cada impressão.
}

Sexto Empírico refere-se aqui à querela sobre a qual discorremos no capítulo sobre epistemologia estoica, acerca das impressões serem ou mudanças

${ }^{179}$ Adv. Rhet. 8. 
ou impressões na alma. Bem, se a querela persistiu, então não havia concordância a respeito disso, não havia $\alpha \rho \mu o v i ́ \alpha$ ou $\sigma v \mu \varphi \omega v i ́ \alpha$, mas sim $\delta 1 \alpha \varphi \omega v i ́ \alpha$, urgindo a suspensão de juízo acerca do modus operandi das apreensões.

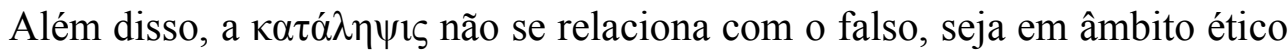
(o mal, ou o vício $=\kappa \alpha \kappa o ́ v)$ ou gnosiológico, mas a retórica, sim, quando o orador defende a causa do adúltero ou do ímpio e engana os juízes ${ }^{181}$, não há, portanto, $\kappa \alpha \tau \alpha ́ \lambda \eta \psi 1 \varsigma$ na retórica, então a retórica não é arte, do ponto de vista da própria conceituação estoica, algo ainda mais agravado pela aporia que Sexto faz emergir entre, por um lado, os da Stoá e, por outro lado, os discípulos de Platão e o peripatético Critolau, que rejeitaram a retórica alegando que era um mero $\operatorname{artifício~}^{182}$.

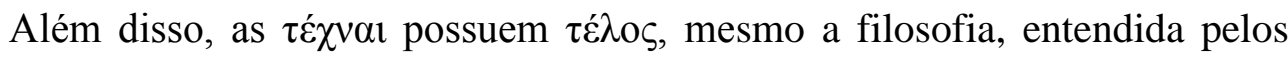

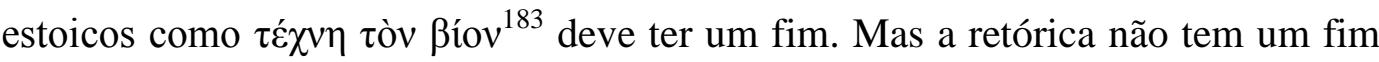
estável e preciso, pois por vezes o retor é insultado, outras vezes não obtém o resultado pretendido e amiúde fracassa ${ }^{184}$.

Há também muitas pessoas que são capazes de argumentar eficientemente, mesmo em tribunais e assembleias, sem treinamento em técnicas retóricas, essas pessoas usufruem da habilidade oratória meramente pela sua experiência prática, e não por obedecerem a um programa teórico estabelecido por professores que, por seu turno, mesmo tendo exaustivamente estudado a retórica, são incapazes de falar bem em público ${ }^{185}$. Começa a desenhar-se aqui uma oposição entre a oratória do retor e o discurso do homem comum, e também entre a habilidade do homem comum, resultado da experiência prática, e as habilidades que os professores pretendem ensinar, baseadas em teorias. Em suma, esboça-se aqui a oposição entre o homem comum, ativo nas $\tau \varepsilon ́ \chi v \alpha l$ - mas a partir de sua própria vida

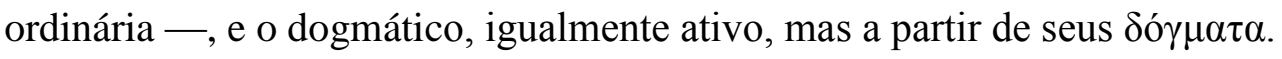

Ora, o conhecimento dos $\delta o ́ \gamma \mu \alpha \tau \alpha$ que compõem as teorias sobre as $\tau \varepsilon \dot{\chi} \chi v \alpha 1$ não faz com que se seja um bom orador, por exemplo — ou seja, o domínio das teorias dogmáticas acerca de uma arte não é de ajuda para desempenho dessa arte —, mas a experiência prática é imprescindível para esse desempenho, e o cético,

\footnotetext{
${ }^{180}$ Adv. Rhet. 9.

${ }^{181}$ Adv. Rhet. 10.

${ }^{182}$ Adv. Rhet. 11-13.

${ }^{183}$ Ver: Adv. Eth. 168.

${ }^{184}$ Adv. Rhet. 14-17.

${ }^{185}$ Adv. Rhet. 17-19.
} 


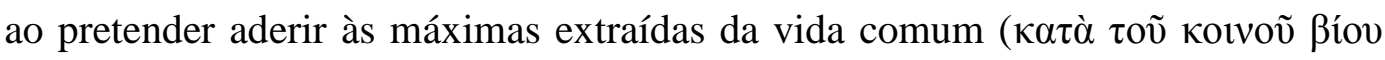
$\dot{\alpha} \pi \circ \varphi \theta \dot{\varepsilon} \gamma \mu \alpha \tau \alpha)$ está muito mais próximo de adquirir essa experiência, ao passo que o dogmático arrisca-se a uma má execução de uma técnica por não dispor de experiência, mesmo possuindo arcabouço teórico.

Aprofundando a rejeição da retórica como arte, Sexto Empírico apresenta outro argumento também oriundo de Critolau e da academia: que as artes são úteis e os homens nãos as expulsam das cidades, mas a retórica é banida por sua hostilidade, como ocorreu em Creta (sob o legislador Tales) e Esparta (sob Licurgo), porque subverte as leis e compromete-se mais com arengas do que com a clareza $^{186}$.

A retórica não é útil para o próprio retor: ele precisa perder seu tempo indo a assembleias, tribunais e cartórios; envolve-se com criminosos; deve discursar agressivamente; e cultiva muitos inimigos. Tampouco é útil para as cidades: torna as leis volúveis; ora aconselha a obediência a um decreto, ora a revogação do mesmo; coaduna com o parasitismo da cidade e do povo; incita a bajulação; alega servir ao benefício público, mas não o faz; e desfavorece o povo. A retórica não é só inútil, é prejudicial ${ }^{187}$.

Se o ceticismo preconiza o retorno à vida comum, o critério para as ações são as ações dos homens ordinários, que exercem as $\tau \dot{\varepsilon} \chi v \alpha \iota$ aprendidas com a experiência prática e se comunicam através de um uso ordinário da linguagem, sem adesão a teorias sobre o discurso. Contrariamente, a retórica é um uso especial da linguagem, construído a partir da obediência a técnicas discursivas, e frequentemente é oposta ao uso comum da linguagem e aos parâmetros para as ações cultivados no seio da vida ordinária, assim, a retórica lesa o povo e abala seus pactos, é aversa à vida comum.

Acrescente-se a isso que Sexto Empírico atribui esse argumento (de que a retórica é prejudicial à $\pi$ ó $\lambda \iota_{\varsigma}$ ) aos acadêmicos ${ }^{188}$ que, por seu turno, ergueram o

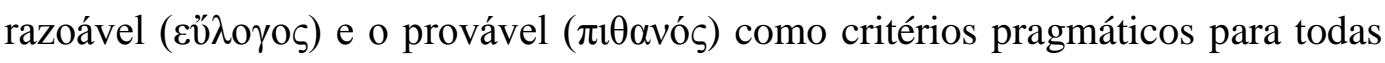
as ações, e que são critérios consensuais cuja eficácia é atestada no âmbito da coletividade.

Contra a argumentação abertamente cética acadêmica, surge a réplica abertamente estoica que assere que a retórica é má somente quando é utilizada por

${ }^{186}$ Adv. Rhet. $19-26$.
${ }^{187}$ Adv. Rhet. $26-43$. 
alguém mau, ela não é má em si, mas quando usada por alguém bom e sábio, produz o bem como resultado. Contudo, o sábio estoico, se não é completamente inexistente, é raro, da mesma forma, o uso sábio da retórica, se não for completamente inexistente, será raro ${ }^{189}$, ironiza Sexto.

\subsubsection{As refutações às definições da retórica como ciência do discurso e produtora da persuasão}

\section{A primeira refutação da retórica como ciência do discurso remete-se a uma aporia} levantada em $A d v$. Gram.131 acerca da definição de discurso, onde não há

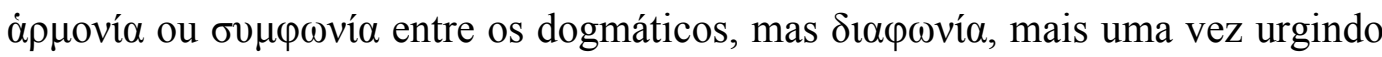
a suspensão de juízo, agora acerca do significado de $\lambda \varepsilon \varepsilon^{\xi} \iota^{190}$.

Apesar da indeterminação do conceito de $\lambda \varepsilon^{\xi} \xi 1 \zeta$, Sexto prossegue analisando a possibilidade de a retórica ser a ciência do discurso, cuja finalidade é propiciar a boa oratória ${ }^{191}$. Mas ela não ensina isso, ao invés, ensina artifícios (por exemplo:

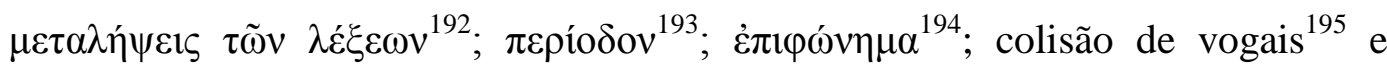

\footnotetext{
${ }^{188}$ Adv. Rhet. 43.

${ }^{189}$ Adv. Rhet. 44-47.

${ }^{190} A d v$. Rhet. 48-49. Em seguida, ao longo dos passos $A d v$. Rhet. 49-51 Sexto Empírico faz um resumo de sua argumentação contra a definição de retórica como $\tau \dot{\varepsilon} \chi v \eta$.

${ }^{191}$ Adv. Rhet. 52.

${ }^{192}$ Adv. Rhet. 54 = "metalepse das expressões". A metalepse, enquanto artifício retórico, consiste em atribuir um efeito presente a uma causa remota. Ou seja, trata-se em geral de um procedimento pelo qual se faz referência a um objeto por meio de algo que possui apenas uma relação remota com esse mesmo objeto. Em muitos casos, a expressão é utilizada para expressar simplesmente "substituição de sentido" ou "uso de uma palavra por outra".

${ }^{193}$ Adv. Rhet. 57 = "sentenças periódicas". Trata-se de um tipo de sentença complexa que coloca a cláusula principal de uma oração no seu fim. Ou seja, as orações subordinadas e demais modificadores são colocadas antes da oração principal, de tal modo que o sentido total fique suspenso e incompleto até o fim do período. Em muitos casos, esse procedimento pode até mesmo prejudicar a pronta compreensão da frase. Ver, a esse respeito: 'BALDWIN, C. S. Composition, Oral and Written. Los Angeles: University of California Press, 1922'.

${ }^{194} A d v$. Rhet. 57 = "epifonema". Como termo técnico da retórica, designa a frase final de um discurso, elaborada em tom geralmente sentencioso e ornamental, por meio da qual o retórico procura preparar ou conduzir o ouvinte a certa recepção da mensagem.

${ }^{195} A d v$. Rhet. 57. Em nome da eufonia, os gregos implementavam vários tipos de alterações fonéticas. As alterações vocálicas, citadas aqui por Sexto Empírico, são, basicamente, a elisão (do

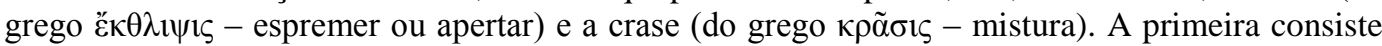
no desaparecimento de uma vogal breve final diante da vogal ou do ditongo inicial da palavra

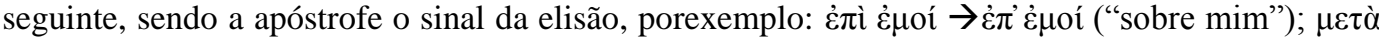

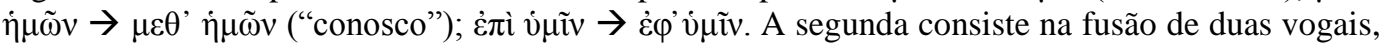
uma final e outra inicial, principalmente entre substantivos, conjunções e pronomes. Quando isso

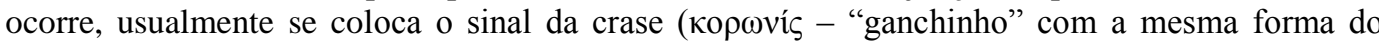
espírito fraco) no interior da palavra, marcando, assim, as duas sílabas em que se deu a crase.

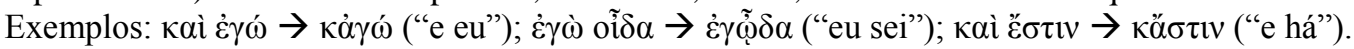




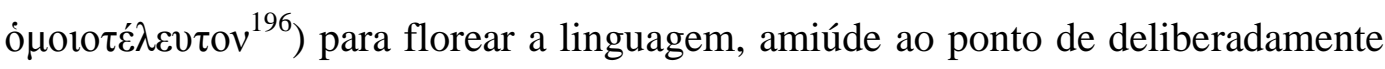
confundir os ouvintes, e indo assim mais uma vez contra a linguagem ordinária, que é erigida por Sexto como critério pragmático do bom discurso ${ }^{197}$.

Nos passos anteriores de $A d v$. Rhet., Sexto Empírico empreendeu uma argumentação largamente inspirada pelos acadêmicos contra a definição da retórica como $\tau \dot{\varepsilon} \chi \vee \eta$, mas, como para Sexto os acadêmicos são dogmáticos, devese investigar a própria argumentação provisoriamente adotada, verificando se há a possibilidade de suscitar aporias quanto a ela e quanto a filosofia da academia. Dessa forma, se antes Sexto investigou a finalidade da retórica definida como arte, agora parte para a investigação acerca de sua finalidade, mas em um caso em que ela é definida como ciência. Sendo mais preciso, Sexto examina a possibilidade de a retórica, considerada ciência, ter uma finalidade, a persuasão (ou o provável = $\pi(\theta \alpha v o ́ \varsigma)$, que é o critério acadêmico para a ação e conhecimento ${ }^{198}$.

Para tal é preciso definir a persuasão, de três diferentes maneiras:

... o termo "provável" é usado em três sentidos: em um sentido, o que é claramente verdade e que, produzindo uma visão de verdade, leva-nos ao assentimento ( $\kappa \alpha \theta^{\prime}$

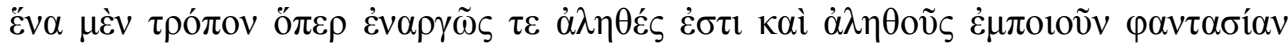

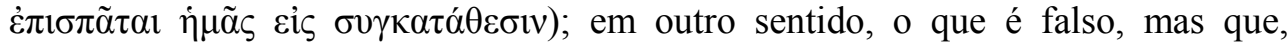

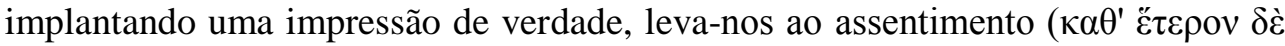

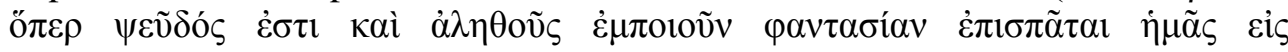

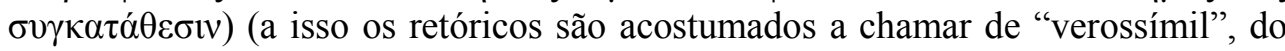
fato de que é semelhante à verdade); e, em um terceiro sentido, é o que participa da

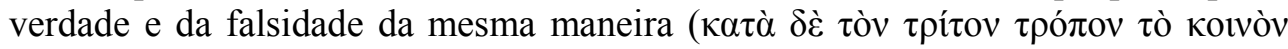

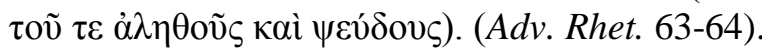

Por seu turno, a passagem citada acima se relaciona diretamente com outra passagem ( $A d v . \log$. I, 174; que citarei abaixo) na qual se discute o critério de verdade, assim, na passagem acima, mais do que discutir a definição da retórica como ciência do discurso, discute-se também o critério:

A probabilidade, na presente instância, é usada em três sentidos: no primeiro, é

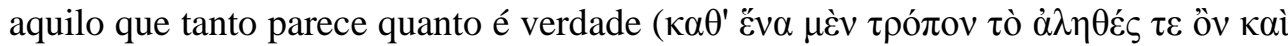

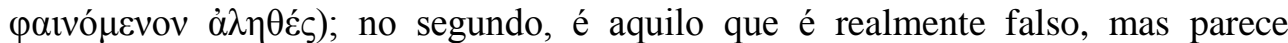

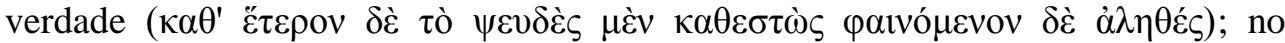

\footnotetext{
196 Adv. Rhet. 57 = "homoteleuto". Pode ser traduzido como "terminações similares". Em contextos retóricos, expressa a utilização deliberada de terminações similares em finais de palavras, frases ou parágrafos. Ou seja, fornecendo já um exemplo, ocorre quando se finalizam as frases com a mesma terminação, "fazendo-as rimar, dando ares de poetar".

${ }^{197}$ Adv. Rhet. 53-59.

${ }^{198}$ Adv. Rhet. 60-63.
} 
terceiro, é aquilo que é ao mesmo tempo tanto verdadeiro quanto falso ( $\kappa \alpha \tau \grave{\alpha} \delta \dot{\varepsilon}$

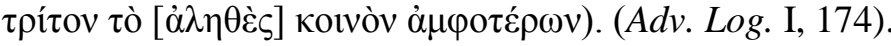

Comparando $A d v$. Rhet. 63-64 com $A d v$. Log. I, 174 percebemos algumas discrepâncias. Quanto à primeira definição de persuasão ou de provável ( $\pi \imath a \alpha v o ́ \varsigma)$, como indicativa da verdade, em Adv. Rhet. 63-64 o provável, a partir da verdade, produz uma "visão de verdade" ( $\dot{\alpha} \lambda \eta \theta$ oṽ $\varsigma \dot{\varepsilon} \mu \pi$ oเoṽv $\varphi \alpha v \tau \alpha \sigma i ́ \alpha v){ }^{199}$; ao passo que

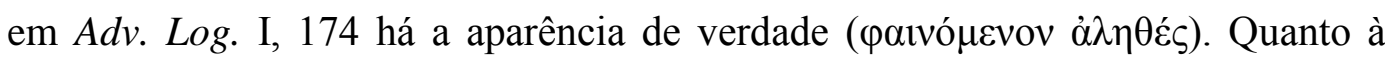
segunda definição, como uma mentira ou falsidade que produz uma indicação de verdade, em $A d v$. Rhet. 63-64 o provável produz, a partir do falso, uma

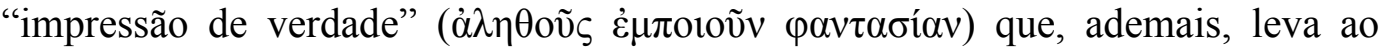
assentimento; por outro lado, em $A d v$. $\log$. I, 174 há a oposição entre ser falso e

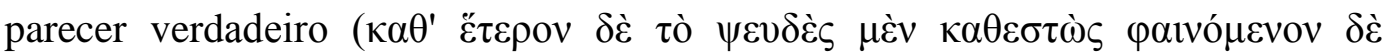
$\dot{\alpha} \lambda \eta \theta \dot{\varepsilon} \varsigma)$. A terceira definição é semelhante em ambas passagens: pode haver algo que participe simultaneamente da verdade e da falsidade.

Em Adv. Rhet. 63-64 Sexto Empírico usa constantemente o vocábulo

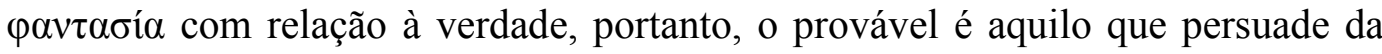
verdade porque a impressão que o objeto gera é verdadeira, ou o provável persuade de uma verdade que não existe, porque a impressão é falsa, e nos leva a assentir erroneamente. No caso de $A d v . \log$. I, 174 são as aparências (o que aparece $=$ paıvó $\mu \varepsilon v o v)$ que estão em jogo, e podem apresentar uma verdade, em consonância com o objeto mesmo, ou podem parecer uma verdade, embora sejam falsas.

Ora, $\varphi \alpha$ vó $\mu \varepsilon v o v$ e $\varphi \alpha v \tau \alpha \sigma i ́ \alpha$ não são sinônimos, apesar da distinção ser sutil. O primeiro se refere às aparições dos objetos aos sentidos, mas mesmo que não haja quem os observe, ainda assim os objetos gerariam aparições, embora não se possa saber isso ao certo uma vez que para tal seria preciso observar seu comportamento quando não observados, um paradoxo. O último vocábulo se refere ao paıvó $\varepsilon$ vov quando percebido, e tão-somente quando isso ocorre. $\mathrm{Ou}$ seja, aıvó $\mu \varepsilon v o v$ se referiria aqui à aparição do objeto mesmo independentemente de um observador, ao passo que $\varphi \alpha v \tau \alpha \sigma i ́ \alpha$ seria o objeto a partir do momento em

\footnotetext{
${ }^{199}$ Compare com a versão latina de Herveti: "veri procreans visionem", ou seja, "que produz visão de verdade". Ressaltamos que, em Cícero (Acad.), "visio", "visum" e "visionem" são os termos latinos para a $\phi \alpha v \tau \alpha \sigma i ́ \alpha$ estoica. Da mesma forma, "quod videri visum comprehendible" é uma expressão ciceroniana que refere-se à $\kappa \alpha \tau \alpha \lambda \eta \pi \tau$
} 
que causa uma impressão a um observador. Ademais, $\varphi \alpha v \tau \alpha \sigma i ́ \alpha$ se torna um conceito estoico, não obstante tenha sido apropriado pela academia a partir mesmo de Arcesilao quando da discussão contra os estoicos acerca do critério de verdade. Por seu turno, contra a terminologia estoica das impressões (e dogmática, que gerou inúmeras contendas, sobre a qual não há unanimidade, somente aporias), os céticos pirrônicos pretenderam aderir ao palvó $\mu \varepsilon v o v$, que parece existir antes mesmo das teorias, tanto as que pretendem definir o que é uma impressão, quanto as que pretendem definir o seu conteúdo. Sendo mais claro, os céticos pirrônicos pretendem viver de acordo com um tipo de percepção que não é alvo de teorias, não pode ser discutido e é coercitivo.

Dessa forma, a discussão sobre o critério que perpassa todo $A d v$. Log. I adentra pela consideração da questão por Platão ( $A d v$. Log. I, 141-145), depois pelos platônicos Espeusipo e Xenócrates ( $A d v$. Log. I, 145-150) e pela academia em fase cética (Adv. Log. I, 150-174), quando Sexto Empírico introduz o supracritério do paıvó $\mu \varepsilon v o v$ como suporte ao $\pi \imath \theta \alpha v o ́ \varsigma$, o critério de Arcesilao. Em seguida Sexto esmiúça a defesa acadêmica do seu $\pi \imath \theta \alpha v o ́ \varsigma(A d v$. Log. I, 174-190), mas, se o paıvó $\mu \varepsilon v o v$ é o critério derradeiro por detrás do $\pi \imath \alpha$ ós, porque ele não basta? A resposta se dá pelo exemplo dos cirenaicos, para quem o paıvó bastaria como critério ( $A d v$. Log. I, 190-201). Ao contrapor acadêmicos e cirenaicos em $A d v$. Log. I, o objetivo de Sexto é demonstrar a aporia entre duas escolas de origem socrática acerca de um mesmo assunto, contudo, em P.H. I, 215, Sexto Empírico claramente diz que os cirenaicos são semelhantes aos pirrônicos quanto ao critério: ambos aderem às aparências.

Voltando a $A d v$. Rhet. 63-64, a relação estabelecida entre os conceitos de $\pi \imath \theta \alpha v o ́ \varsigma$ e de $\varphi \alpha v \tau \alpha \sigma i ́ \alpha$ também conduzirá a aporia, tendo em vista que são mutuamente excludentes, assim urgirá a suspensão de juízo tanto acerca do conceito estoico quanto acerca do acadêmico. Mas, acompanhemos a argumentação sextiana.

Recorrendo a uma ironia, Sexto Empírico pede que os dogmáticos persuadam-no de qual a melhor definição de persuasivo (Adv. Rhet. 64): se (1) a persuasão é do verdadeiro, então, “a persuasão produzida pela retórica é supérflua" ( $A d v$. Rhet. 65), por que não há necessidade de uma arte que persuada 
que o assassino pego em flagrante realmente é culpado do delito, isso é tão evidente quanto "é dia", ou "estou falando agora". Além disso, se a retórica é persuasiva, é também dissuasiva, de modo que concerne então tanto ao verdadeiro quanto ao falso, ou a pontos de vista opostos em geral, e não exclusivamente persuade da verdade; se (2) ela implanta uma impressão de verdade a partir do falso, a argumentação empregada será a mesma que a do caso (1), assim, a retórica terá que envolver um conhecimento tanto do falso como do verdadeiro e ser igualmente dissuasiva ou persuasiva de ambos, então não persuadirá exclusivamente do falso; (3) se ela, finalmente, persuade ou dissuade igualmente do verdadeiro ou do falso, então ela não é uma ciência, porque não se relaciona exclusivamente com a verdade, não há, portanto, uma retórica que seja uma ciência do discurso cuja finalidade é persuadir (Adv. Rhet. 65-72).

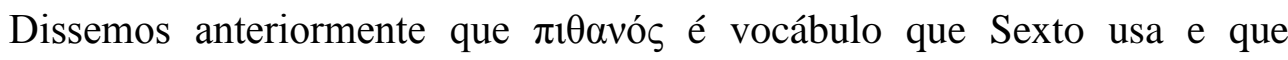
traduzimos aqui como persuasivo, e também que, empregado na discussão sobre o critério, o $\pi \imath \theta \alpha v o ́ \varsigma$ (traduzido como provável) é o critério acadêmico (de Carnéades e Clitômaco) para a ação prática e o conhecimento. Se em Adv. Rhet. 65-72 a argumentação sextiana se refere à retórica, definida como ciência, e se

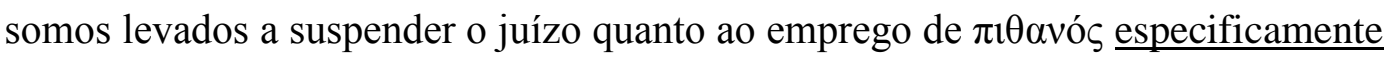

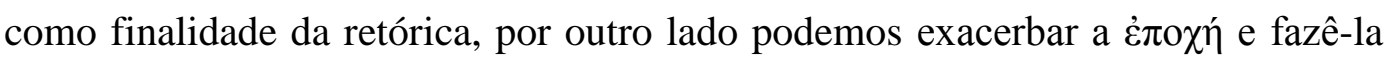
incidir sobre o $\pi \imath \theta \alpha v o ́ \varsigma$ de um modo geral, atingindo o critério acadêmico para a ação e o conhecimento, e não exclusivamente sua teoria retórica, através do emprego da metodologia preconizada em P.H. I, 5 (que relata que há argumentos céticos específicos e gerais) e em P.H. III, 280 (que relata que os argumentos céticos diferem em potência, de acordo com a potência das patologias dogmáticas, sendo mais fortes quanto mais fortes forem as doenças).

Ademais, em $A d v$. Rhet. 65-72 desenhou-se uma argumentação que contrapôs persuasão e impressão e, se fomos levados à suspensão quanto à persuasão, como demonstramos acima, devemos também demonstrar como somos levados à suspensão sobre as impressões.

Assim, se (1) a persuasão é da impressão verdadeira, da mesma forma que não é preciso uma arte que persuada da verdade, uma vez que é autoevidente, tampouco é preciso assentir a uma impressão da verdade, porque se é autoevidente

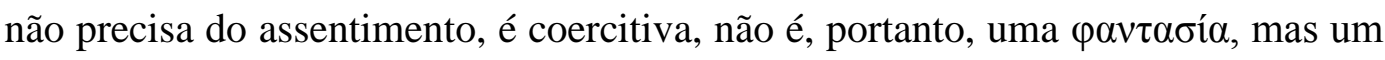
paıvó $\mu \varepsilon v o v$, e independe da interpretação do receptor. Se (2) a persuasão implanta 
uma impressão de verdade a partir do falso, como é possível que o persuadido discirna tal coisa? Ou seja, no caso em que a pessoa é iludida pela habilidade de um orador mal-intencionado, ela não sabe que está sendo iludida enquanto está sendo iludida. Se assim é, então essa pessoa tem uma impressão errônea, mas que toma por verdadeira por que foi persuadida, ora, persuasão e impressão se confundem aqui, mas, considerando que são critérios mutuamente excludentes tal confusão não é possível. Se (3) a impressão tanto pode ser do verdadeiro como do falso, assim como a persuasão, e se a discernibilidade entre o verdadeiro e o falso é impossível, porque a impressão participa tanto da falsidade quanto da verdade, então ela não serve como critério de verdade. A partir das três argumentações

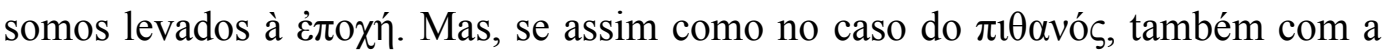

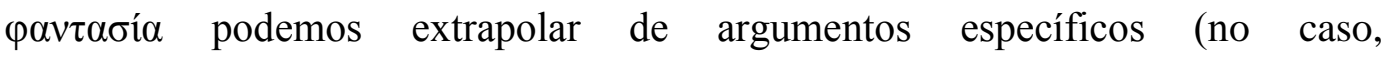
especificamente concernentes à retórica) para argumentos gerais, podemos então suspender o juízo acerca da teorética estoica sobre as impressões em geral.

\subsection{Adv. Rhet. 73-113}

Nos passos $A d v$. Rhet. 73-113, os últimos quarenta passos da obra, a argumentação de Sexto Empírico não suscita maiores aporias acerca dos critérios dogmáticos, são passos talvez mais interessantes para literatos ou historiadores.

Os passos $A d v$. Rhet. 73-85 persistem na discussão do propósito da retórica, Sexto, recorrendo a uma argumentação já anteriormente lançada, refuta que o propósito dela seja a vitória - porque o retor é mais vezes derrotado do que vitorioso - , ou a utilidade, uma vez que ele tem que se envolver com criminosos.

Com relação à discussão quanto ao resultado da terapia cética: o retorno à

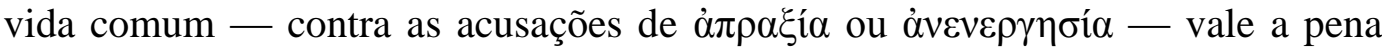
citar os passos $A d v$. Rhet. 76-79, em que Sexto considera que mesmo aqueles que persistem afirmando que a finalidade da retórica é a persuasão devem concordar que ela é inadequada para produzir tal fim:

... o discurso que faz surgir a boa vontade nos juízes é aquele que é persuasivo; mas o que faz surgir a boa vontade não é o discurso retórico, mas aquele que é simples e reflete o estilo ordinário. Pois ao estilo do retórico, todos que detestam ares de superioridade se opõem. Pois mesmo que o retórico sustente o que é justo, eles imaginam que coisas injustas lhes parecem justas, não por causa da real natureza 
das coisas, mas por causa das trapaças do retórico. Mas, por outro lado, com o discurso do homem comum todos simpatizam, sentindo sua fragilidade, e atribuem grande justiça ao que é menos justo por ser sustentado por uma pessoa comum e ordinária. E, por isso, aos atenienses, em dias antigos, não era permitido terem um advogado para defendê-los em um julgamento. Na corte do Areópago, cada homem, com o melhor de sua habilidade, fazia um discurso em sua própria defesa, sem trapaças ou malabarismos verbais. Ademais, se os retóricos cressem na sua própria afirmação de possuir o poder da persuasão, eles não deveriam excitar piedade ou lamentação ou indignação, ou outros sentimentos desse tipo, coisas que não persuadem, mas pervertem as mentes dos juízes e obscurecem a justiça. (Adv. Rhet. 76-79).

Os passos $A d v$. Rhet. 85-113 visam refutar que a retórica tenha uma matéria com a qual lide, e também que tenha partes, algo que não ocorre porque para tal precisaria ter um conteúdo específico, mas não tem.

Agora, com relação à nossa defesa mais anterior de que o escopo da suspensão cética de juízo não se restringe à teorética filosófica ou científica, citeramos os interessantes passos Adv. Rhet. 97-99 em que, diante de uma contenda levada a tribunal, acerca de uma dívida, os juízes suspendem o juízo:

\begin{abstract}
Um jovem homem, tomado pelo desejo pela, retórica foi até ele (o retor Córax) e prometeu que o pagaria a quantia que ele cobrasse, caso ele ganhasse seu primeiro caso. E quando o trato foi feito, e o jovem dispunha de habilidade suficiente, Córax cobrou seus honorários, mas o outro disse "não". Ambos então recorreram ao tribunal e tiveram seu caso julgado; e então, é dito, Córax pela primeira vez utilizou um argumento deste tipo: que, se ele ganhou ou perdeu o caso, ele deve receber a quantia; se ele ganhou, porque ganhou, e se ele perdeu, de acordo com os termos do trato; pois seu oponente concordou em pagar-lhe a quantia se ele ganhasse seu primeiro caso, então, se ele ganhou, era assim obrigado a desfazer o débito. E após os juízes o terem aplaudido por falar de modo justo, o jovem, por seu turno, começou o seu discurso e utilizou o mesmo argumento, nada alterando: "Se eu ganho", disse ele, "ou se sou vencido, não sou obrigado a pagar a Córax a taxa; se ganho, porque ganhei; e se perco, de acordo com os termos do contrato; pois prometi pagar a taxa se ganhasse meu primeiro caso, mas, se perdesse, não deveria pagar". Os juízes, então, levados a um estado de suspensão do juízo e

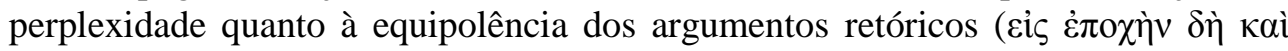

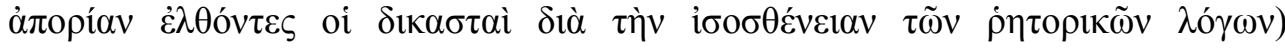
conduziram ambos para fora do tribunal... (Adv. Rhet. 97-99).
\end{abstract}

Finalmente, pretendíamos aplicar a nossa 'via média' a um objeto específico: $A d v$. Rhet, verificando a sua eficiência como ferramenta interpretativa. Para tal teríamos que demonstrar: (1) que o cético se conserva ativo em uma $\tau \varepsilon ́ \chi \vee \eta$, dispondo da experiência adquirida com a prática, e não com teorias; (2) que o cético é capaz de se comunicar, dispondo do uso da linguagem dos homens comuns, sem floreios; (3) que o critério cético para a ação, conhecimento e 
desempenho das $\tau \varepsilon ́ \chi v \alpha ı$ não são crenças, mas a coerção pelos fenômenos; (4) que

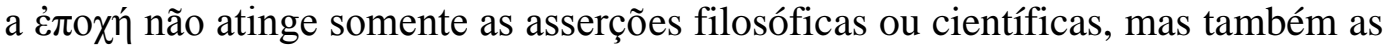
presentes em outros âmbitos. Dessa forma, parece-nos que a interpretação de $A d v$. Rhet. se enquandra plenamente nos rigores exigidos por aquela 'via média'. 


\section{Conclusão}

Com vistas a defender a coerência pragmática do ceticismo através de uma 'via média' interpretativa aplicada, finalmente, à $A d v$. Rhet., tivemos antes que fazer um levantamento de como surge a crítica que acusa que o ceticismo é inviável na prática $(\dot{\alpha} \pi \rho \alpha \xi i ́ \alpha)$.

Começamos com os Modernos porque pensamos que os argumentos anticéticos contemporâneos são herdeiros dos argumentos Modernos, humeanos, talvez. Depois, nos voltamos para os Antigos, quando o argumento surge em Aristóteles, que acusa o discurso dos que pretendem refutar o princípio de não contradição - os protocéticos de Diógenes Laércio e Sexto Empírico - de

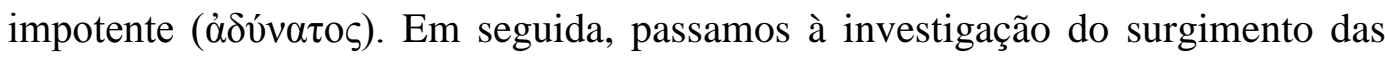
críticas anticéticas ao longo de cada uma das etapas de desenvolvimento do ceticismo antigo, até Sexto Empírico, quando pudemos testar a 'via média' como ferramenta para a interpretação de $A d v$. Rhet.

Não pretendendíamos uma interpretação inequívoca ou mesmo derradeira, e também não desejávamos esgotar aqui todas as obras de Sexto, escolhemos $A d v$. Rhet. porque pensamos que lá se encontram indícios textuais que comprovam a eficácia da 'via média', quais sejam: o retorno à vida comum; a imunidade dessa vida à teorética filosófica; mas sem o insulamento, que não existe na filosofia

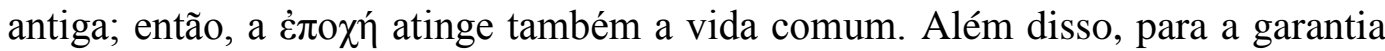
dessa eficácia seria preciso que houvesse em Sexto uma discriminação entre o uso cético da linguagem, alinhado ao uso ordinário, contra usos assertóricos e específicos da linguagem, uma diferenciação também presente em Adv. Rhet. 


\section{Referências bibliográficas}

\subsection{Fontes primárias: textos e traduções}

*AESCHINES. Aeschines with an English translation by Charles Darwin Adams, Ph.D. Londres: William Heinemann Ltd., 1919.

*ALEXANDER OF APHRODISIAS. On Aristotle's "Topics 1". In: Ancient Commentators on Aristotle. Cornell: Cornell University Press, 2001.

*APPIAN. The Civil Wars. Londres: MACMILLAN AND CO. LTD., 1899.

*APPIAN. The Foreign Wars. Nova Iorque: MACMILLAN AND CO. LTD., 1899.

*ARISTOPHANES. Clouds. In: The Comedies of Aristophanes. Londres: Bohn, 1853

*ARISTOTLE. The Works of Aristotle. Londres: Encyclopaedia Britannica, 1952.

*ARISTOTLE. The Complete Works of Aristotle. The Revised Oxford Translation. BARNES, J (ed.), 2 vols. Princeton: Princeton University Press.

*ATHENEUS. The Deipnosophists. GULICK, C. B. (trad.). Londres: William Heinemann Ltd, 1927.

*AULUS GELLIUS. Aulus Gellius: Attic Nights, 2 vols. In: Loeb Classical Library. Harvard: Harvard University Press, 1927.

*BLANK, D. L. Ancient Philosophy and Grammar, The Syntax of Apollonius Dyscolus. The American Philological Association, 1982.

*CALCIDIUS. Commentaire au Timée de Platon. In: Histoire Des Doctrines De L'antiquite Classique. Paris: Vrin, 2012.

*CLEOMEDES. Cleomedes' Lectures on Astronomy: A Translation of The Heavens. In: Hellenistic Culture and Society. California: University of California Press, 2004. 
*CLEMENT OF ALEXANDRIA. Miscellanies (Stromata). Memphis: Bottom of the Hill Publishing, 2012.

*DECLEVA CAIZZI, F. (org.). Pirrone testimonianze. Nápoles: Bibliopolis, 1981.

*DEMOSTHENES. Demosthenes with an English translation by C. A. Vince, M. A. and J. H. Vince. Londres: William Heinemann Ltd, 1926.

*DIELS, H.; KRANZ, W. Die Fragmente der Vorsokratiker, 3 vols. Berlim: Weidmann, 1974.

*DIOGENES LAERTIUS. Lives of eminet philosophers. HICKS, R. D. (trad.). Londres: William Heinemann, 1975.

*DIÔGENES LAÊRTIOS. Vidas e Doutrinas dos Filósofos Ilustres. Trad. Mário da Gama Kury. Brasília: Editora UNB, 2008.

*DIOGENES OF OINOANDA. The Epicurean Inscription by Diogenes of Oinoanda (c. 200 CE). SMITH, M. F. (trad.). Nápolis: Bibliopolis, 1992.

*DORANDI. Filodemo. Storia dei filosofi [.] : Platone e l'Academia, La scuola di Epicuro, 12. Nápolis, 1991.

*DORANDI. Filodemo, Storia dei filosofi: La stoà da Zenone a Panezio (PHerc. 1018). In: Philosophia antiqua, vol. LX, Leyde-New York-Köln 1994.

*DORANDI. Filodemo. Gli Stoici (PHerc. 155 e 339). In: CErc 12 (1982): 91133.

*EPICTETO (FLÁVIO ARRIANO). O Encheirídion de Epicteto. DINUCCI, A. (trad.). São Cristóvão: Universidade Federal de Sergipe, 2012.

*EPICTETUS (FLAVIUS ARRIANUS). Discourses, 2 vols. In: Loeb Classical Library. Harvard: Harvard university Press, 1925.

*EURIPIDES. Orestes. In: WHITNEY, J. O.; O’NEILL, E. (eds.) The Complete Greek Drama. Nova Iorque: Random House, 1938.

*EUSEBIUS OF CESAREA. Praeparatio Evangelica. Kindle edition.

*GALEN. On the natural faculties. Harvard: Harvard University Press, 1991.

*GALENI. De Placitis Hippocratis et Platonis. Berlim: Akademie Verlag, 2005.

*GAZZINELLI, G. G. A Vida Cética de Pirro. São Paulo: Edições Loyola, 2009. 
*GIANNANTONI, G. (org.). Socratis et Socraticorum Reliquiae, collegit, disposuit, apparatibus notisque instruxit Gabriele Giannantoni, 4 vols. Nápolis: Bibliopolis, 1985.

*GORGIAS. Encomium of Helen. MACDOWELL, D. (trad.). Glasgow: Bristol Classics, 1982.

*HANNO. The Periplus of Hanno: A Voyage of Discovery Down the West African Coast. Nova Iorque: Cornell University Library, 2009.

*HERODOTUS. Herodotus, with an English translation by A. D. Godley. Cambridge: Harvard University Press, 1920.

*HESIOD. Theogony \& Works and Days. SCHLEGEL, C.; WEINFIELD, H. (trad.). Michigan: Michigan University Press, 2006.

*HESIOD. Theogony. Work and Days. Testimonia. MOST, G. W. (trad.). Cambridge: Harvard University Press, 2006.

*HIPPOCRATES. The Genuine Works of Hippocrates. Nova Iorque: Dover, 1868 .

*HOMER. The Odyssey. MERRIL, R. (trad.). Michigan: Michigan University Press, 2002.

*HOMERO. Ilíada. NUNES, C. A. (trad.). São Paulo: Atena Editora, s/d.

*ISOCRATES. Isocrates with an English Translation in three volumes, by George Norlin, Ph.D. Londres: William Heinemann Ltd., 1980.

*KIRK, G. S.; RAVEN, J. E.; SCHOFIELD, M. Os filósofos pré-socráticos. Lisboa: Fundação Calouste Gulbekian, 1994.

*L. ANNEUS SENECA. Ad Lucilium Epistulae Morales, 3 vols. GUMMERE, M. (trad.). Londres: William Heinemann Ltd, 1917-1925.

*L. ANNEUS SENECA. L. Annaeus Seneca. Moral Essays. Londres e Nova Iorque: Heinemann, 1928.

*L. ANNEUS SENECA. Natural Questions. In: The Complete Works of Lucius Annaeus Seneca. Chicago: University Of Chicago Press, 2010.

*LONG, A.A.; SEDLEY, D.N. The Hellenistic Philosophers: translation of the principal sources, with philosophical commentary, 2 vols. Cambridge: Cambridge University Press, 1987. 
*LONG, H. S. Diogenis Laertii vitae philosophorum, 2 vols. Oxford: Oxford University Press, 1964.

*LUCIAN. Luciani Samosatensis Opera. JACOBITZ, K. (trad.). Leipzig: Teubneri, 1896.

*LUCIAN. Works, with an English Translation by. A. M. Harmon, 5 vols. Londres: William Heinemann Ltd, 1936.

*LUCIANO. Hermótimo. In: Luciano, vol. II. Coimbra: Imprensa da Universidade de Coimbra, 2012.

*LYSIAS. Lysias with an English translation by W.R.M. Lamb, M.A. Londres: William Heinemann Ltd., 1930.

*M. TULLIUS CICERO. M. Tulli Ciceronis Rhetorica. A. S. Wilkins, 1902.

*M. TULLIUS CICERO. De Fato. Leipzig: Teubner, 1915.

*M. TULLIUS CICERO M. Tulli Ciceronis scripta quae manserunt omnia, fasc. 43. de Finibus Bonorum et Malorum. SCHICHE, T. (trad.). Leipzig: Teubner, 1915.

*M. TULLIUS CICERO. de Natura Deorum. PLASBERG (trad.). Leipzig: Teubner, 1917.

*M. TULLIUS CICERO. Tusculanae Disputationes. POHLENZ (trad.). Leipzig: Teubner, 1918.

*M. TUlLIUS CICERO. On Academic Scepticism. Cambridge: Hackett Publishing Company, 2009.

*M. TULLIUS CICERO. Academicorum reliquiae cum Lucullo. PLASBERG (trad.). Leipzig: Teubner, 1922.

*MATES, B. The Skeptic Way: Sextus Empiricus's Outlines of Pyrrhonism. Oxford: Oxford University Press, 1996.

*MEKLER. Academicorum Philosophorum Index Herculanensis. Berlin, 1902.

*METRODORUS OS LAMPSACUS. Metrodori Epicurei Fragmenta collegit scriptoris incerti Epicurei Commentarium moralem, subiecit Alfredus Koerte. Ulan Press, 2012.

*PHILODEMUS OF GADARA. Philodemus on piety: critical text with 
commentary, 2 vols. OBBINK, D. (trad.). Oxford: Clarendon Press, 1996.

*PHOTIOS. Photius: The Bibliotheca. Londres: Duckworth Publishing, 1994.

*PLATÃo. Diálogos. NUNES, C. A. (trad.). Belém: EDUFPA, 2001. *PLATON. Oeuvres Complètes. Paris: Les Belles Lettres, 1920-1956.

*PLUTARCH. Plutarch's Morals. Translated from the Greek by several hands. Corrected and revised by. William W. Goodwin, PH. D. Cambridge: Press Of John Wilson and son, 1874.

*POLYBIUS. The Complete Histories of Polybius. Kansas: Digireads.com, 2009.

*SEXTO EMPÍRICO. Contra os retóricos. BRITO, R. P.; HUGUENIN, R. (trad.). São Paulo: EdUNESP, 2013.

*SEXTUS EMPIRICUS. Complete Works of, 4 vols. BURY, R. G. (trad.). In: Loeb Classical Library. Harvard: Harvard University Press, 2006.

*SEXTUS EMPIRICUS. Outlines of Scepticism. ANNAS, J.; BARNES, J. (eds.) Cambridge: Cambridge University Press, 2000.

*SEXTUS EMPIRICUS. Against the Ethicists. BETT, R. (trad.). Oxford: Claredon Press, 1997.

*SEXTUS EMPIRICUS. Against the Grammarians. BLANK, D. L. (trad.). Oxford: Claredon Press, 1998.

*SIMPLICIUS. Simplicius: On Aristotle's "Physics 3". In: Ancient Commentators on Aristotle. Cornell: Cornell University Press, 2002.

*SIMPLICIUS. On Aristotle's "On the Heavens 1.10-12". In: Ancient Commentators on Aristotle. Cornell: Cornell University Press, 2006.

*SOPHOCLES. The Women of Trachis and Philoctetes. A new translation in verse by Robert Torrance. Houghton Mifflin, 1966.

* STOBAEUS. Anthologium. WACHSMUTH, O. H. (ed.). Berlim: Weidmann, 1912.

*SYRIANUS. Syrianus: On Aristotle Metaphysics 3-4. In: Ancient Commentators on Aristotle. Cornell: Cornell University Press, 2008.

*TAVERSA. Index Stoicorum Herculanensis. Gênes, 1952.

*TAYLOR, C. C. W. (org. \& trad.). The atomists: Leuccipus and Democritus, 
fragments. In: The Phoenix Presocratics. Toronto: University of Toronto Press, 2010.

*THEMISTIUS. The Private Orations of Themistius. In: Transformation of the Classical Heritage. California: University of California Press, 1999.

*TUCIDIDES. História da Guerra do Penopoleso. KURY, M. G. (trad.). Brasília: Editora UNB, 2001.

*VON ARNIN, H. F. A. Stoicorum Veterum Fragmenta, 4 vols. Munich: K.G. SAUR VERLAG, 2010.

*XENOFONTE. Memoráveis. Coimbra: Imprensa da Universidade de Coimbra, 2009.

*XENOPHON. Xenophon in Seven Volumes. MARCHANT, E. C. (trad.). Marchant. Londres: William Heinemann Ltd., 1923.

\subsection{Fontes secundárias: artigos e livros}

*ALMEIDA, G. A. Aspectos da filosofia da linguagem. In: MARCONDES de Souza Filho, D. (org.). Significado, verdade e ação. Niterói: EdUFF,1986.

*ALVES Eva, L. A. O Primeiro Cético (Acerca da Coerência do Pirronismo). In: SILVA Filho, Waldomiro (org.). O Ceticismo e a Possibilidade da Filosofia. Ijuí: Editora Unijuí, 2005.

*ANNAS J.; BARNES J. The Modes of Scepticism: Ancient Texts and Modern Interpretations. Cambridge: Cambridge University Press, 1985.

*ANNAS, J. Doing Without Objective Values: Ancient and Modern Strategies. In: SCHOFIELD, M; STRIKER, G. (eds.). The Norms of Nature: Studies in Hellenistic Ethics. Cambridge: Cambridge University Press, 1986.

$*$ . Scepticism About Value. In: POPKIN, R. H. (org.). Scepticism in the History of Philosophy. Holanda: Kluwer Academic Publishers, 1996.

$*$ . Hume e o Ceticismo Antigo. In: Sképsis, n 2, 2007. 
*ATALLA, D. A. Crítica e interpretación del escepticismo en el artículo de Hegel Relación del Escepticismo com la Filosofia, de 1802. In: Kriterion, n ${ }^{\circ}$ 93,1996.

*AUBET, M. E. The Phoenicians and the West: Politics, Colonies and Trade. Cambridge: Cambridge University Press, 1993.

*AUSTIN, J. L. How to do Things with Words: The William James Lectures delivered at Harvard University in 1955. Oxford: Clarendon, 1962.

$*$ How to Talk: Some Simple Ways. In: Proceedings of the Aristotelian Society, ${ }^{\circ}$ 53, 1953.

$*$ Performative Utterances. In: URMSON, J. O.; WARNOCK, G. J. (eds.). Austin, Philosophical Papers. Oxford: Oxford University Press, 1961. * Performative-Constative. In: SEARLE, J. (ed.). The Philosophy of Language. Oxford: Oxford Universiy Press, 1971.

*BARNES, J; SCHOFIELD, M; BURNYEAT, M. (orgs.). Doubt and Dogmatism, Studies in Hellenistic Epistemology. Oxford: Claredon Press, 1980.

*BARNES, J. The Beliefs of a Pyrrhonist. In: Proceedings of the Cambridge Philological Society, n²08. Cambridge, 1982.

$*$ The Toils of Scepticism. Cambridge: Cambridge University Press, 1990. $*$ . Proof Destroyed. In: BARNES, J; SCHOFIELD, M; BURNYEAT, M. (orgs.). Doubt and Dogmatism, Studies in Hellenistic Epistemology. Oxford: Claredon Press, 1980.

*BAYLE, P. Historical and Critical Dictionary: Selections. Cambridge: Hackett Publishers Company, 1991.

$*$ - Commentaire Philosophique sur ces paroles de Jésus-Christ. Amazon Digital Services: Kindle Edition.

*BEISER, F. C. The Fate of Reason: German Philosophy from Kant to Ficht. Londres: Harvard University Press, 1987.

*BERKELEY, G. Tratado Sobre os Princípios do Conhecimento Humano. In: Coleção os Pensadores. São Paulo: Abril Cultural, 1973. 

Três Diálogos entre Hilas e Filonus em Oposição aos Céticos e

Ateus. In: Coleção os Pensadores. São Paulo: Abril Cultural, 1973.

*BEVAN, Edwyn. Stoïceiens et Sceptiques. Paris: Société d'Édition 'Les BellesLettres", 1927.

*BICCA, L. Hegel: $O$ Ceticismo na Dialética. In: $O$ que nos faz pensar, n 25, 2009.

$*$ Carnéades em Roma: ceticismo e dialética. In: Revista Sképsis, ano IV $, n^{\circ} 05,2009$.

$*$ Racionalidade Moderna e subjetividade. São Paulo: Loyola, 1997.

*BITTNER, R. Máximas. In: Studia Kantiana, n 5, novembro de 2003.

*BLASQUEZ, J. M. Fenicios y cartagineses en el Mediterraneo. Madrid: Ediciones Catedra S.A., 2004.

*BOBZIEN, S. Lógica. In: INWOOD, B (org.). Os Estóicos. São Paulo: Odysseus, 2006.

*BOLZANI, R. A Epokhé Cética e Seus Pressupostos. In: Sképsis, nº 3 - 4, 2008. $*$ Algumas Observações Sobre "Terapia e Vida Comum”. In: Sképsis, $\mathrm{n}^{\circ} 1,2007$.

$*$ . Acadêmicos versus Pirrônicos. In: Discurso, 29, 1998.

*BRANCACCI, A. La filosofia di Pirrone e le sue relazioni com il cinismo. In: GIANNANTONI, G. (org.). Lo scetticismo ântico. Roma, 1981.

*BRANIGAN, C. The Circumnavigation of Africa. In: Classics Ireland, vol. 1. Dublin: Classical Association of Ireland, 1994.

*BRITO, R. P. Pirro e Índia: similaridades entre pirronismo e jainismo. In: Revista Alétheia, vol. 1/ 2, janeiro a julho de 2011.

$*$ O estoicismo e suas máximas: Epicteto. In: Breviário de Filosofia Pública, $\mathrm{n}^{\circ} 78,11 / 2012$.

*BROCHARD, Victor. Os Céticos Gregos. São Paulo: Editora Odysseus, 2010. *BRUNDELL, B. Pierre Gassendi: From Aristotelianism to a New Natural Philosophy. Amsterdã: Kluwer Academic Publishers, 1987. 
*BRUNSCHWIG, J. Proof Defined. In: BARNES, J; SCHOFIELD, M; BURNYEAT, M. (orgs.). Doubt and Dogmatism, Studies in Hellenistic Epistemology. Oxford: Claredon Press, 1980.

$*$ Estudos e Exercícios de Filosofia Grega. São Paulo: Edições

Loyola, 2009.

*BUENO, V. C. A. Significado e ato ilocucionário. In: MARCONDES de Souza Filho, D. (org.). Significado, verdade e ação. Niterói: EdUFF,1986.

*BURNYEAT, M. F.; FREDE, M. (orgs.). The Original Sceptics. Cambridge: Hackett Publishing Company, 1998.

*BURNYEAT, M. F. Can the Sceptic Live his Scepticism? In: BARNES, J; SCHOFIELD, M; BURNYEAT, M. (orgs.). Doubt and Dogmatism, Studies in Hellenistic Epistemology. Oxford: Claredon Press, 1980.

$*$ Pode o Cético Viver seu Ceticismo? In: Trilhas Filosóficas, $\mathrm{n}^{\circ}$ 04, II, 2010.

$*$ The Sceptic in His Place and Time. In: The Original Sceptics. Cambridge: Hackett Publishing Company, 1998.

* . O Cético em Seu Lugar e Tempo. In: Revista Kínesis, vol. II, $\mathrm{n}^{\circ} 04,2010$. $*$ Protagoras and Self Refutation in Later Greek Philosophy. In: Philosophical Review $\mathrm{n}^{\circ}$ 85, 1976.

*CAO, G. M. The Prehistory of Modern Scepticism: Sextus Empiricus in Fifteenth-century Italy. In: Journal of the Warburg and Courtauld Institutes, Vol. 64, 2001. The Warburg Institute Stable.

*CARTER, B. L. The quiet Athenian. Oxford: Claredon Press, 1986.

*CASSIN, B. O efeito sofístico. São Paulo: Editora 34, 2005.

*CLARKE, T. The Legacy of Skepticism. IN The Journal of Philosophy', volume $69,20$.

*CORNFORD, F. M. Antes e Depois de Sócrates. São Paulo: Martins Fontes, 2007.

*COUSSIN, Pierre. L'origine e L'évolution de L'EPOXH. In: Revue des Etudes Grecques, $\mathrm{n}^{\circ}$ 42, 1929. 
*CRAVEN, J. B. Dr. Robert Fludd, Mersenne and Gassendi. Montana: Kessinger Publishing, 2010.

*DAVISON, J. A. The First Greek Triremes. In: The Classical Quarterly, vol. 41. Cambridge: Cambridge University Press, 1947.

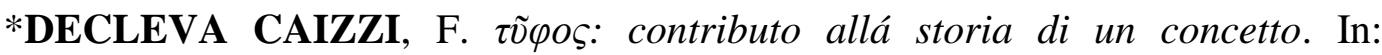
Sandalion $\mathrm{n}^{\circ}$ 3, 1980.

*DENIS, J-F. Sceptiques ou Libertins De La Première Moitié du Xviie Siècle: Gassendi, Gabriel Naudé, Gui-Patin, Lamothe-Levayer, Cyrano de Bergerac. Charleston: Nabu Press, 2010.

*DESCARTES, R. Meditações; Col. Pensadores. São Paulo: Editora Nova Cultural Ltda., 2000.

$*$ . The Philosophical Writings of Descartes, Vol 3: The Corresondence. Cambridge: Cambridge University Press, 1991. $*$ . Meditations, Objections, and Replies. Cambridge: Hackett Publishing Company, 2006 $*$ Meditations on First Philosophy: With Selections from the Objections and Replies. Cambridge: Cambridge University Press, 1996. $*$ . A discourse of a Method for the Well Guiding of Reason, and the Discovery of Truth in the Sciences (1649). Early English Books Online Editions, ProQuest, 2011.

*DESMOND, W. Cynics. Berkeley: University of California Press, 2008.

*FISCHER, S. Pierre Gassendi's Philosophy and Science: Atomism for Empiricists. Leiden: Brill Academic Publishers, 2005.

*FLORIDI, L. The Diffusion of Sextus Empiricus's Works in the Renaissance. In: Journal of the History of Ideas, Vol. 56, $\mathrm{n}^{\circ} 1$. University of Pennsylvania Press.

*FOGELIN, R. Hume's Skepticism. In: The Cambridge Companion to Hume. Cambridge: Cambridge University Press, 1993.

$*$ Pyrrhoniam Reflections on Knowledge andJustification. Oxford: Oxford University Press, 1994. $*$ The Tendency of Hume's Scepticism. In: The Skeptical Tradition. Berkeley: University of California Press, 1983 
*FOLS, P. S. Doubt and Divinity: Cicero's Influence on Hume's Religious Skepticism. In: Hume Studies, volume 20, n 1, 1994.

$*$ . The Bibliographic Bases of Hume's Understanding of Sextus

Empiricus and Pyrrhonism. In: Journal of History of Philosophy, volume 36, ${ }^{\circ} 2$, 1998.

*FORSTER, M. N. Kant and Skepticism. Princeton: Princeton University Press, 2008.

$*$ Hegel and Skepticism. Cambridge: Harvard University Press, 1989.

*FOUCAULT, M. A Hermenêutica do Sujeito. São Paulo: Martins Fontes, 2004.

*FREDE, D. How Sceptical Were the Academic Sceptics? In: POPKIN, R. H. (org.). Scepticism in the History of Philosophy. Holanda: Kluwer Academic Publishers, 1996.

*FREDE, M. As Crenças do Cético. In: Sképsis, n 3-4, 2008.

$*$ . The Skeptic's Beliefs. In: FREDE, M. Essays in Ancient Philosophy. Minessota: University of Minnesota Press, 1989.

$*$ . The Sceptic's Two Kinds of Assent and the Question of the Possibility of Knowledge. In: The Original Sceptics. Cambridge: Hackett Publishing Company, 1998.

$*$ Essays in Ancient Philosophy. Minessota: University of Minnesota Press, 1989.

*FREEMAN, E. A. The History of Sicily from the Earliest Times: Vol. 1. The Native Nations: The Phoenician and Greek Settlements. Boston: Adamant Media Corporation, 2001.

*GASSENDI, P. Three Discourses of Happiness, Virtue and Liberty. Montana: Kessinger Publishing, 2003.

*GIGANTE, M. (org.). La Villa dei Papiri. Nápoles: 1983.

$*$ La bibliothèque de Philodème et l'épicurisme Romain. Paris: Les

Belles Lettres, 1987.

*GOLDSCHMIDT, V. Os diálogos de Platão: estrutura e método dialético. São Paulo: Loyola, 2010. 
*GOULET-CAZÉ, M-O; BRANHAM, R. B. (orgs.). Os cínicos: o movimento cínico na Antiguidade e seu legado. São Paulo: Loyola, 2007.

*GRIFFIN, M. Cinismo e romanos: atração e repulsa. In: GOULET-CAZÉ, MO; BRANHAM, R. B. (orgs.). Os cínicos: o movimento cínico na Antiguidade e seu legado. São Paulo: Loyola, 2007.

*GUIMARÃES, L. A Melancholy Skeptic. In: Kriterion, Revista de Filosofia, $\mathrm{n}^{\circ}$ 108. Belo Horizonte: Editora da UFMG, 2003.

*HADOT, P. Exercices Spirituels et Philosophie Antique. Paris: Éditions Albin Michel S.A., 1993.

$*$ . O que é a Filosofia Antiga? São Paulo: Edições Loyola, 2004.

*HANKINSON, R. J. Epistemologia estoica. In: INWOOD, B (org.). Os Estóicos. São Paulo: Odysseus, 2006. $*$ . Estoicismo e medicina. In: INWOOD, B (org.). Os

Estóicos. São Paulo: Odysseus, 2006. $*$ . The sceptics (arguments of the philosophers). Londres: Routledge, 1998.

*HEGEL, G. W. F. Introdução à História da Filosofia. São Paulo: Hemus, 2004. $*$ La relation du scepticisme avec la philosophie. Paris:Vrin, 1986.

$*$ Leçons sur l'histoire de la philosophie: Vol. 4. La philosophie grecque.Paris:Vrin, 1975.

$*$ Fenomenologia do Espírito. Petrópolis: Vozes, 1992.

*HILEY, D. R. The Deep Challenge of Pyrrhonian Scepticism. In: Journal of History of Philosophy, volume 25, $\mathrm{n}^{\circ}$ 2, 1987.

*HUET, P-D. A Philosophical Treatise Concerning the Weakness of Human Understanding. Gale Eighteenth Century Collections Online, 2010.

*HUME, D. A Teatrise of Human Nature. SELBY-BIGGE, L. A. (ed.); NIDDITCH, P. H. (rev.). Oxford: Oxford University Press, 1978.

*_. Enquiry Concerning Human Understanding. In: Enquires Concerning Human Understanding and Concerning the Principles of Morals, 
SELBY-BIGGE, L. A. (ed.); NIDDITCH, P. H. (rev.). Oxford: Oxford University Press, 1975.

$*$ Dialogues concerning Natural Religion. In: David Hume:

Philosophical Works, vol. II . Londres: Green and Grose, 1886.

$*$ Letters of David Hume. GREIG, J. Y. T. (org.). Oxford: Oxford University Press, 2011.

$*$ Ensaios Morais, Políticos e Literários. In: Coleção os Pensadores.

São Paulo: Abril Cultural, 1973.

* Carta de um cavalheiro a seu amigo em Edimburgo. In: Sképsis, $\mathrm{n}^{\circ}$

$1,2007$.

$*$ Investigações Sobre o Entendimento Humano e Sobre os Princípios da Moral. São Paulo: UNESP, 2003.

$*$ . Tratado da Natureza Humana. São Paulo: UNESP, 2009.

$*$ . My own life. In: http://www.consciencia.org/my-own-life-by-davidhume-1776

*INWOOD, B (org.). Os Estóicos. São Paulo: Odysseus, 2006.

*INWOOD, B.; GERSON, L. P. Hellenistic Philosophy: Introductory Readings. Indianápolis: Hackett, 1997.

*JIGOULOV, V. S. The Social History of Achaemenid Phoenicia: Being a Phoenician, Negotiating Empires. Londres: Equinox Publishing, 2010.

*JOY, L. S. Gassendi the Atomist: Advocate of History in an Age of Science. Cambridge: Cambridge University Press, 2002.

*KANT, I. Crítica da Razão Pura. Lisboa: Fundação Calouste Gulbekian, 2001. $*$ . Critique of Pure Reason. Cambridge: Cambridge University Press, 2005.

Fundamentação da metafísica dos costumes. ALMEIDA, G. A. (trad.). São Paulo: Barcarolla \& Discurso Editorial, 2009. * Crítica da razão prática. ROHDEN, V. (trad.). São Paulo: Martins Fontes, 2003. 
$*$ . A religião dentro dos limites da simples razão. MOURÃO, A. (trad.).

Covilhã: Universidade da Beira Interior, 2008.

*LANDIM FILHO, R. F. Significado e verdade. In: MARCONDES de Souza Filho, D. (org.). Significado, verdade e ação. Niterói: EdUFF,1986.

*LARROQUE, P. T. de. Lettres de Peiresc à Borrilly, à Bouchard et à Gassendi (1626-1637). Amazon Digital Services: Kindle Edition.

*LEAL-TOLEDO, Gustavo. O Cético e Suas Crenças: a Aparente Duplicidade de Sexto Empírico. In: Dissertatio, $\mathrm{n}^{\circ}$ 27- 28, 2008.

*LIBERA, A. A Filosofia Medieval. São Paulo: Edições Loyola, 1998.

*LOLORDO. Pierre Gassendi and the Birth of Early Modern Philosophy. Amazon Digital Services: Kindle Edition.

*LONG, A. A. A tradição socrática: Diógenes, Crates e a ética Helenística. In: GOULET-CAZÉ, M-O; BRANHAM, R. B. (orgs.). Os cínicos: o movimento cínico na Antiguidade e seu legado. São Paulo: Loyola, 2007.

*LOQUE, F. F. Ceticismo e religião no início da Modernidade: a ambivalência do ceticismo cristão. São Paulo: Loyola, 2012.

* MAIA Neto, J. R. O Ceticismo na Primeira Metade do Século XVII e a Tradição Cética. In: Kriterion, ${ }^{\circ} 98,1998$.

*MARCONDES de Souza Filho, D. Finding One's Way About: High Windows, Narrow Chimneys, and Open Doors. Wittgenstein's "Scepticism" and Philosophical Method. In: POPKIN, R. H. (org.). Scepticism in the History of Philosophy. Amsterdã: Kluwer Academic Publishers, 1996.

$*$ Ceticismo, Filosofia Cética e Linguagem. In:

SILVA Filho, Waldomiro (org.). O Ceticismo e a Possibilidade da Filosofia. Ijuí: Editora Unijuí, 2005.

$*$ - A "Felicidade" do Discurso Cético: o

Problema da Auto-refutação do Ceticismo. In: O Que Nos Faz Pensar, n 8, 1994. $*$ Juízo, Suspensão do Juízo e Filosofia Cética.

In: Sképsis, n 1, 2007. 

Noûs vs Logos. In: O Que Nos Faz Pensar, n

$1,1989$.

$*$ Rústicos X Urbanos: o Problema do

Insulamento e a Possibilidade da Filosofia Cética. In: O Que Nos Faz Pensar, n 24, 2008.

$*$ - Filosofia da linguagem: da teoria do significado à teoria da ação. In: MARCONDES de Souza Filho, D. (org.). Significado, verdade e ação. Niterói: EdUFF,1986. * (org.). Significado, verdade e ação. Niterói:

EdUFF,1986.

*MOMIGLIANO, A. Os limites da helenização: a interação cultural das civilizações grega, romana, céltica, judaica e persa. Rio de Janeiro: Zahar Editores, 1991.

*MOORE, G. Escritos Filosóficos. São Paulo: Nova Cultural, 1989.

*MOREAU, P-F. Le Stö̈cism au XVIe et au XVIIe Siècle. Paris: Éditions Albin Michel S.A., 1999.

*NAVIA. L. E. Diógenes, o cínico. São Paulo: Odysseus, 2009.

*NUSSBAUM, M. Skeptic Purgatives: Therapeutic Arguments in Ancient Skepticism. In: Journal of History of Philosophy, volume 29, n 4, 1991.

*O' KEEFE, T. Epicureanism. Berkeley: University of California Press, 2010.

*PALMER, J. A. Skeptical Investigation. In: Ancient Philosophy, n² 20, 2000.

*PEREIRA, O. P. Rumo ao Ceticismo. São Paulo: Editora Unesp, 2006.

*PETIT, P. A civilização Helenística. São Paulo: Martins Fontes, 1987.

*PIERRIS, G. de. Hume's Pyrrhoniam Skepticism and the Belief in Causal Laws. In: Journal of History of Philosophy, volume 13, n 3, 1975.

*POPKIN, R. História do Ceticismo: de Erasmo a Spinoza. Rio de Janeiro: Francisco Alves, 2000. $*$ . Sources of Knowledge of Sextus Empiricus in Hume's Time. In: Journal of the History of Ideas, Vol. 54, $\mathrm{n}^{\circ}$ 1, 1993. University of Pennsylvania Press. 

. David Hume: His Pyrrhonism and His Critique of Pyrrhonism.

In: The Philosophical Quarterly, Vol. 1, n 5, 1951. Blackwell Publishing for The Philosophical Quarterly.

$*$ . Ceticismo. EIGENHEER, E. M. (org.). Niterói: EdUFF, 1996.

*REED, C. M. Maritime Traders in the Ancient Greek World. Cambridge: Cambridge University Press, 2004.

*REEVE, C. D. C. Socrates in the Apology: an essay on Plato's Apology of Socrates. Indianápolis: Hackett Publishing Company, 1989.

*RORTY, R.; SCHNEEWIND, J. B.; SKINNER, Q.; (orgs.). Philosophy in History: Essays on the Historiography of Philosophy. Cambridge: Cambridge University Press, 1985.

*ROVIGHI, S. V. História da Filosofia Moderna. São Paulo: Edições Loyola, 1999.

*SCHOFIELD, M.; ROWE, C. The Cambridge history of Greek and Roman political thought. Cambridge: Cambridge University Press, 2000.

*SCHOFIELD, M. Ética estoica. In: INWOOD, B (org.). Os Estóicos. São Paulo: Odysseus, 2006.

*SEARLE, J. R. Speech Acts, an Essay in the Philosophy of Language. Cambridge: Cambridge University Press, 1970.

*SEDLEY, D. A escola, de Zenon a Ário Dídimo. In: INWOOD, B (org.). Os Estóicos. São Paulo: Odysseus, 2006.

*__. Os protagonistas. In: Revista Índice, vol. 02, n 01- 2010/1.

*SELLARS, J. Stoicism. Berkeley: University of California Press, 2006.

*SHELFORD, A. G. Transforming the Republic of Letters: Pierre-Daniel Huet and European Intellectual Life, 1650-1720. Rochester: University of Rochester Press, 2007.

*SMITH, Plínio Junqueira. Terapia e Vida Comum. In: Sképsis, n 1, 2007.

*SNELL, B. A cultura grega e as origens do pensamento europeu. São Paulo: Perspectiva, 2005.

*SPINOZA, B. Tratado Teológico-Político. São Paulo: Martins Editora, 2008. 
$*$ Ética. São Paulo: Editora Autêntica, 2009.

*STRAWSON, P. F. Ceticismo e naturalismo: algumas variedades. São Leopoldo: Editota UNISINOS, 2007.

*STRIKER, G. Greek Ethics and Moral Theory. In: The Tanner Lectures on Human Values, 1987.

$*$ Estratégias céticas. BRITO, R. P.; SMITH, P. J. In: Breviário de filosofia pública, $\mathrm{n}^{\circ}$ 56, 04/2012.

* . Sceptical Strategies. In: BARNES, J; SCHOFIELD, M; BURNYEAT, M. (orgs.). Doubt and Dogmatism, Studies in Hellenistic Epistemology. Oxford: Claredon Press, 1980.

*STROUD, B. Hume's Scepticism: Natural Instincts and Philosophical Reflection. In: POPKIN, R. H. (org.). Scepticism in the History of Philosophy. Holanda: Kluwer Academic Publishers, 1996. . Kant and Skepticism. In: The Skeptical Tradition. Berkeley: University of California Press, 1983. . O Ceticismo de Hume: instintos naturais e reflexão filosófica. In:

Sképsis, n 3- 4, 2008.

*TAYLOR, C. Hume and the Enlightenment. Londres: Ashgate, 2011.

*THOMAS, P. F. La Philosophie de Gassendi. Michigan: University of Michigan Library, 1889.

*THORSRUD, H. Ancient Scepticism. Berkeley: University of California Press, 2009.

*V/A. Bulletim of the Institute of Classical Studies. Special Issue: Institute of Classical Studies, Bulletim Supplement, $\mathrm{n}^{\circ}$ 54: Greek and Latin Papyrology. Londres: School of Advanced Studies, University of London, 1986',

*VAZ, P. O Sentido do Ceticismo. In: O Que Nos Faz Pensar, n 8, 1994.

*VOGT, K. Activity, Action and Assent: on The Life of the Pyrrhoniam Sceptic. In: Princeton Colloquium in Ancient Philosophy, 2007.

*WACHSMANN, S. Seagoing Ships \& Seamanship In The Bronze Age Levant (Ed Rachal Foundation Nautical Archaeology). Texas: Texas A\&M University Press, 2008. 
*WARD. The Role of the Phoenicians in the Interaction of Mediterranean Civilizations. Nova Iorque: Syracuse University Press, 1995.

*WILLIAMS, M. Unnatural Doubts, Epistemological Realism and the Basis of Scepticism. Princeton: Princeton University Press, 1996.

*WITTGENSTEIN, L. Tractatus Lógico- Philosophicus. São Paulo: EdUSP, 2001.

$*$ Investigações filosóficas. In: Col. Pensadores. São Paulo:

Nova Cultural, 1999.

\subsection{Obras de referência: dicionários, léxicos e gramáticas}

*BAILLY, A. Díccionaire Grec-Français. Paris: Hachette, 1950.

*BOISACQ, Émile. Diccionaire Étymologique de la langue Grecque, étudiée dans ses Rapports avec les autres Langues Indo-Européennes. Paris: Klincksieck, 1916.

*CHANTRAINE, Pierre. Diccionaire Étymologique de la Langue Grecque. Historie des Mots, 2 vols. Paris: Klincksieck, 1984.

*FRANK, A (ed.). Dictionnaire des Sciences Philosophiques. Paris: Librarie Hachette, 1885.

*FREIRE, Antônio S. J. Gramática Grega. São Paulo: Martins Fontes, 2001.

*HORTA, Guida Neda Barata. Os Gregos e seu Idioma, 2 vols. Rio de Janeiro: Di Giorgio \& Cia. Ltda., 1978/1983.

*JONES, P. V. (org.). O mundo de Atenas, uma introdução à cultura clássica ateniense. São Paulo: Martins Fontes, 1997.

*LIDELL, H. G.; SCOTT, R. A Greek-English Lexicon. revised and augmented throughout by. Sir Henry Stuart Jones. with the assistance of. Roderick McKenzie. Oxford: Clarendon Press, 1940.

*RAGON, E. Gramática grega. São Paulo: Odysseus, 2011.

*SMYTH, Herbert Weir. Greek Grammar. Harvard: Harvard University Press, 1984. 
*TODD, S. C. A Glossary of Athenian Legal Terms. In: Lanni, A (ed.), Athenian Law in its Democratic Context (Center for Hellenic Studies On-line Discussion Series). Republicado em BLACKWELL, C.W (ed.). Dēmos: Classical Athenian Democracy (A. Mahoney and R. Scaife, edd., The Stoa: a consortium for electronic publication in the humanities [www.stoa.org]) edição de março 16, 2003. 


\section{Glossário de termos e expresses gregas}

Observações:

(1) Todos os vocábulos e expressões usados no texto aparecem aqui neste glossário.

(2) As palavras que no texto aparecem declinadas em casos que não sejam o nominativo aparecem aqui no caso original, que é descrito sintaticamente

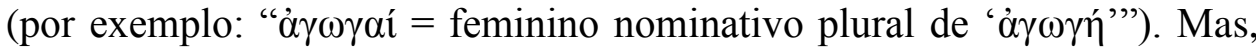
ordenada alfeticamente, fizemos também a entrada do caso nominativo com seu significado (por exemplo: “ $\dot{\alpha} \gamma \omega \gamma \eta ́$ = conduta; persuasão com sentido de condução").

(3) Da mesma forma, as conjugações dos verbos têm a descrição da forma exata com que aparecem no texto (por exemplo: " $\delta 1 \alpha \sigma \kappa \varepsilon ́ \psi \alpha \sigma \theta \alpha \iota=$ aoristo infinitivo médio passivo de ' $\delta 1 \alpha \sigma \kappa \varepsilon ́ \pi \tau o \mu \alpha \imath$ ”’); e, ordenada alfabeticamente, há a entrada de sua forma na primeira pessoa do presente do indicativo ativo grego, seguida de seu significado traduzido no infinitivo português,

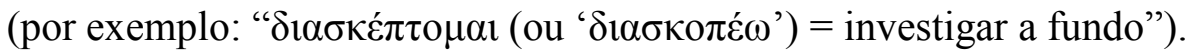

(4) As expressões são dispostas aqui com as traduções exatamente iguais, ou pelo menos levemente diferentes, das que aparecem na tese.
A

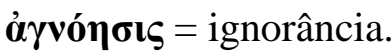

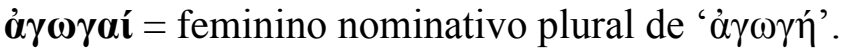
$\grave{\alpha} \gamma \boldsymbol{\omega} \gamma \boldsymbol{\eta}$ = conduta; persuasão com sentido de condução (ser conduzido para...).
$\dot{\boldsymbol{\alpha}} \boldsymbol{\gamma} \boldsymbol{\omega} \gamma \boldsymbol{\eta} \boldsymbol{v} \boldsymbol{\nu}=$ feminino acusativo singular de ' $\dot{\alpha} \gamma \omega \gamma \eta \dot{\eta}$ '.

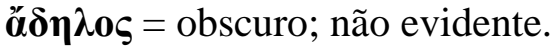
$\grave{\alpha} \delta \eta \dot{\eta} \lambda \omega v=$ neutro genitivo plural de ' $\alpha$ $\delta \eta \lambda \mathrm{o} \varsigma^{\prime}$.

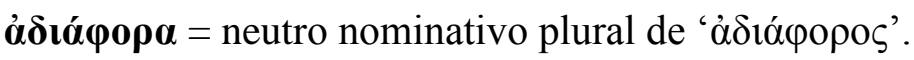


$\grave{\alpha} \boldsymbol{\delta} \mathbf{\iota} \alpha \varphi \rho \mathbf{\imath} \boldsymbol{\alpha}=$ indiferença.

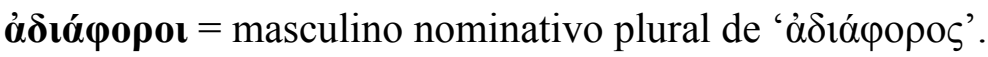

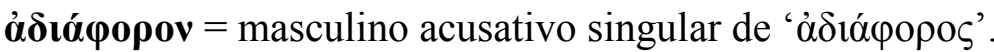

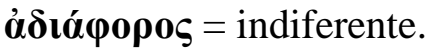

$\grave{\alpha} \delta \mathbf{\delta} \boldsymbol{\alpha} \varphi \hat{\rho} \rho \omega \varsigma$ = indiferentemente.

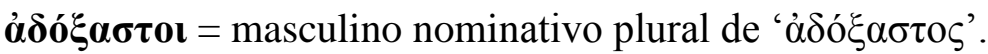

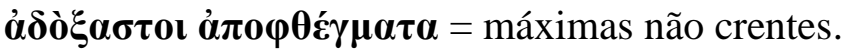

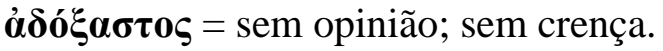

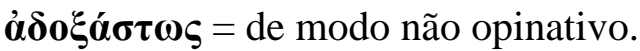

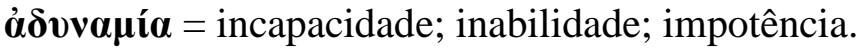

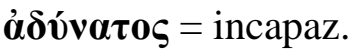

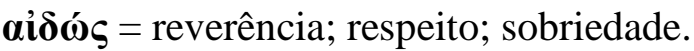

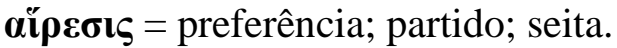

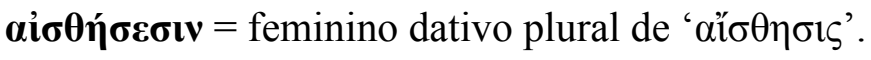

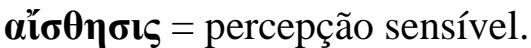

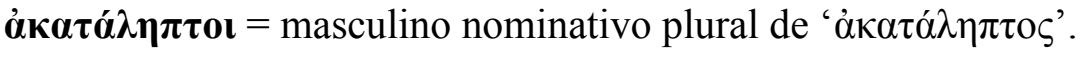

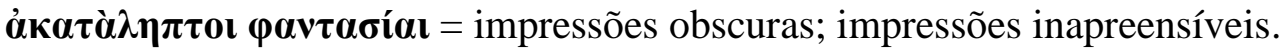

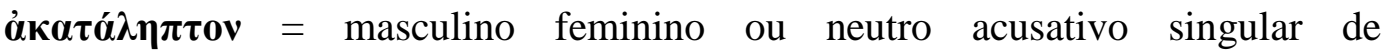

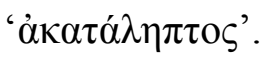

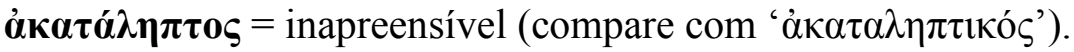

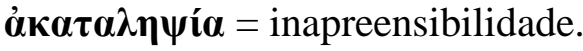

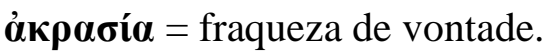

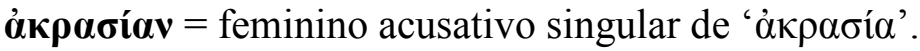




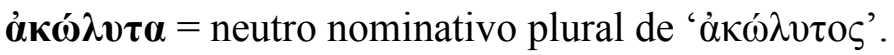

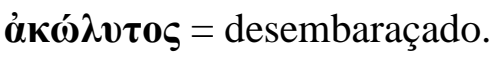

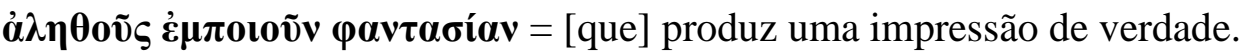

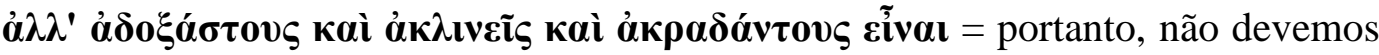
confiar nelas nem um pouco, mas não devemos opinar, inclinarmo-nos, abalarmonos.

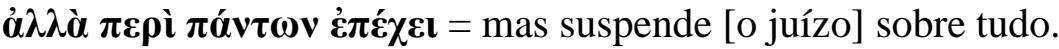

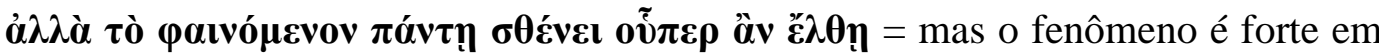
toda parte por onde passa.

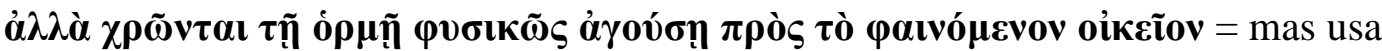
o impulso que leva-o naturalmente ao que parece apropriado.

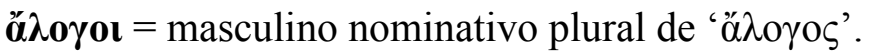

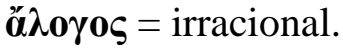

$\grave{\alpha} \mu \varphi \mathbf{L} \boldsymbol{\beta} \eta \tau \dot{\varepsilon} \omega=$ divergir.

$\grave{\alpha} \mu \varphi \iota \sigma \beta \eta \tau$ ́́ $\sigma \varepsilon \mathbf{\imath}=$ terceira pessoa do singular do futuro do indicativo ativo de

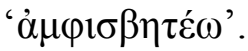

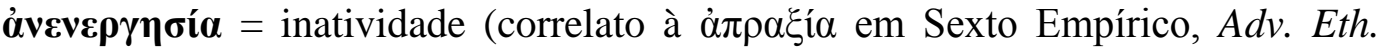
162).

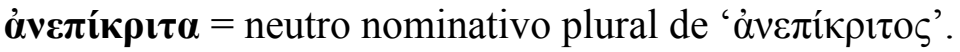

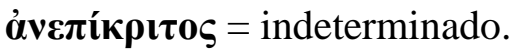

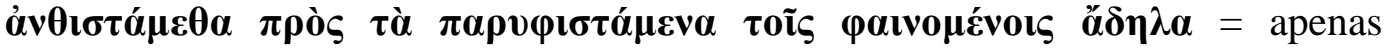
contrapomos aos fenômenos as indicações não-evidentes.

ơv $\theta \rho \omega \pi \mathbf{s}$ = ser humano.

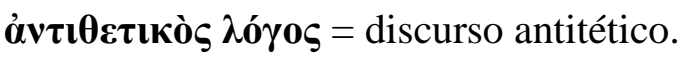

$\dot{\alpha} v \omega \mu \alpha \lambda i ́ \alpha=$ anomalia. 


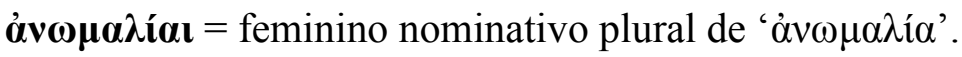

$\dot{\alpha} \boldsymbol{v} \omega \mu \boldsymbol{\alpha} \lambda \mathbf{i} \boldsymbol{\alpha} \mathbf{v}=$ feminino acusativo singular de ' $\alpha \nu \omega \mu \alpha \lambda \dot{\alpha} \alpha$ '.

$\dot{\alpha} \xi \hat{i} \omega \mu \alpha=$ axioma.

$\grave{\alpha} \boldsymbol{\pi} \boldsymbol{\alpha} \theta \boldsymbol{\varepsilon} \iota \boldsymbol{\alpha}=$ impassibilidade; apatia.

$\grave{\boldsymbol{\alpha}} \boldsymbol{\pi} \boldsymbol{\alpha} \boldsymbol{\theta} \dot{\varepsilon} \boldsymbol{\omega}=$ libertar-se.

$\dot{\boldsymbol{\alpha}} \boldsymbol{\pi} \boldsymbol{\alpha} \boldsymbol{\theta} \mathfrak{\jmath} \varsigma=$ sem afecções.

$\grave{\alpha} \pi \alpha \rho \alpha \lambda \lambda \alpha \xi \hat{\imath} \alpha=$ indistinguibilidade.

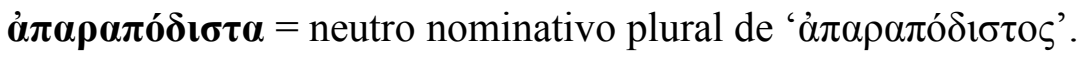

$\dot{\alpha} \pi \alpha \rho \alpha \pi \delta ́ \delta เ \sigma \tau \mathbf{\varsigma} \varsigma=$ desimpedido.

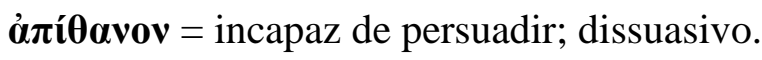

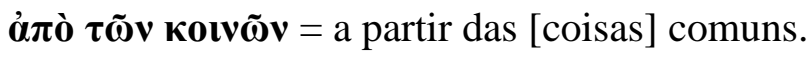

àjopí $\boldsymbol{\alpha}=$ não caminho.

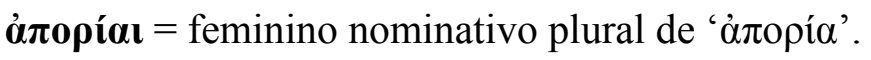

$\dot{\boldsymbol{\alpha}} \boldsymbol{\pi} \boldsymbol{\varphi} \varphi \boldsymbol{\theta} \boldsymbol{\varepsilon} \boldsymbol{\mu} \boldsymbol{\alpha}=$ máxima; apotegma.

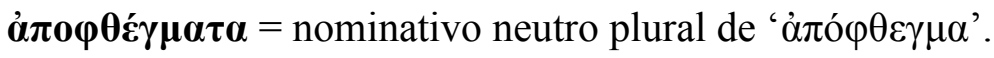

$\dot{\alpha} \pi \rho \alpha \gamma \mu \mathbf{\mu} \boldsymbol{\sigma} v \boldsymbol{\eta}=$ afastamento das coisas públicas.

$\dot{\alpha} \pi \rho \alpha \boldsymbol{\xi} \dot{\imath} \alpha=$ inação.

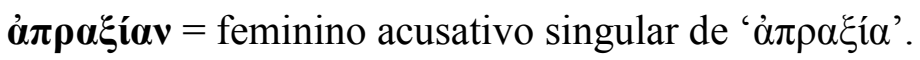

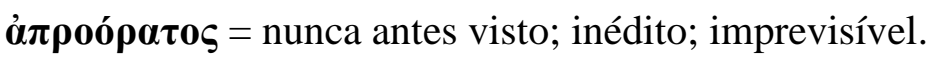

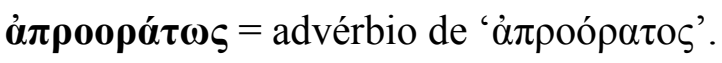

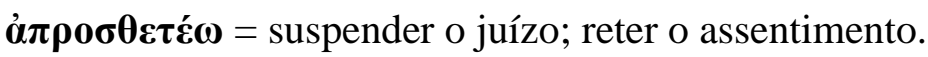

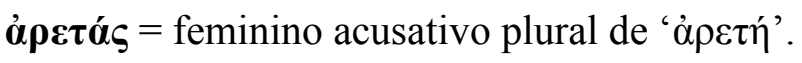

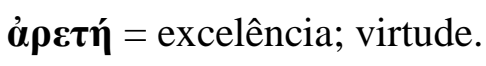


óp $\boldsymbol{\mu}$ oví $\alpha=$ harmonia.

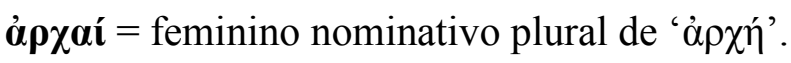

$\grave{\alpha} \rho \chi \eta ́$ = origem; princípio.

ǒ $\sigma \kappa \eta \boldsymbol{\sigma} \varsigma$ = exercício.

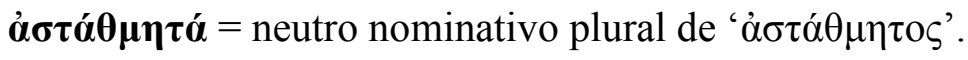

$\dot{\alpha} \sigma \tau \alpha \dot{\alpha} \theta \mu \eta \tau 0 \varsigma$ = instável.

$\grave{\alpha} \sigma \tau \boldsymbol{\gamma} \boldsymbol{\gamma} \boldsymbol{\gamma} \boldsymbol{i} \boldsymbol{\alpha}=$ impassibilidade.

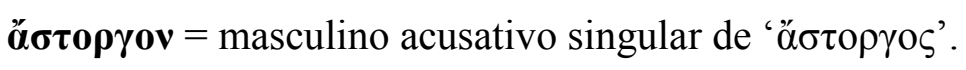

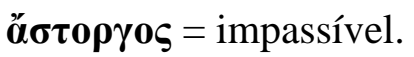

$\dot{\alpha} \tau \boldsymbol{\alpha \rho \alpha} \boldsymbol{\alpha} \mathbf{i} \boldsymbol{\alpha}=$ não perturbação; imperturbabilidade.

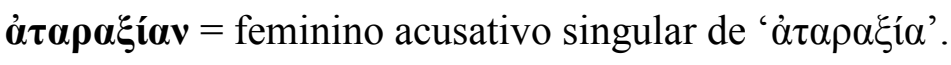

$\dot{\alpha} \tau \varepsilon \chi v^{\prime} \boldsymbol{\alpha} \alpha=$ falta de habilidade; falta de técnica.

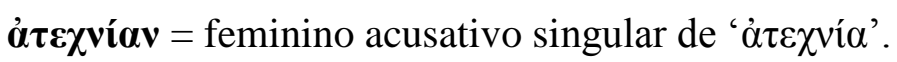

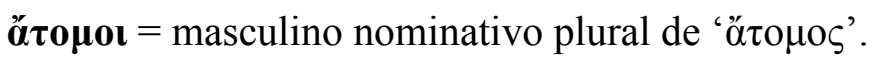

ö́ $\mathbf{0 \mu \rho}=$ indivisível.

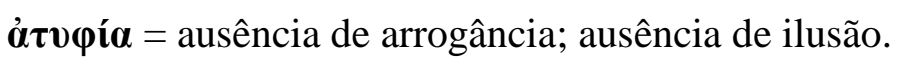

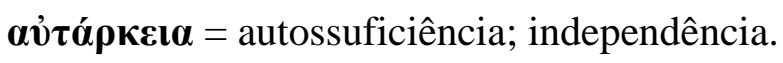

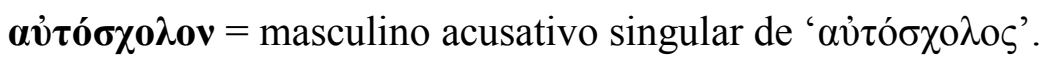

$\boldsymbol{\alpha} \boldsymbol{v} \tau \mathbf{\sigma} \sigma \chi \boldsymbol{o} \boldsymbol{\lambda} \mathbf{o} \varsigma$ = autodidata; quem aprende sozinho.

$\dot{\alpha} \varphi \boldsymbol{\alpha} \boldsymbol{\sigma} \boldsymbol{\alpha} \alpha=$ não asserção.

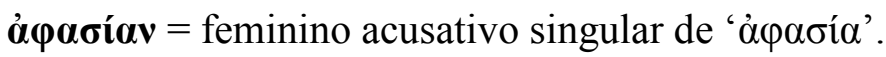

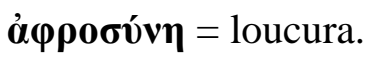


$\Gamma$

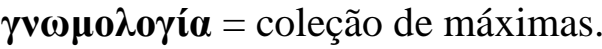

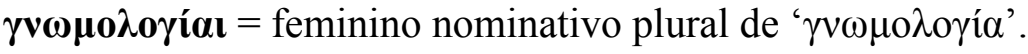

$\Delta$

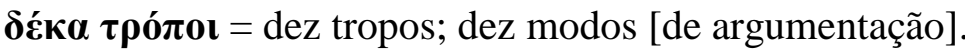

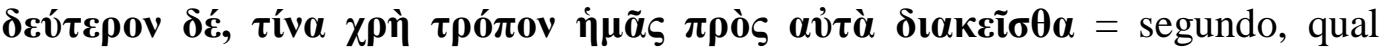
atitude devemos adotar diante delas.

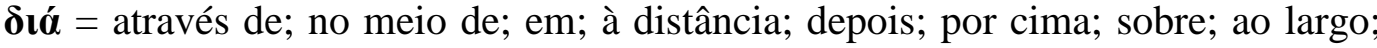
completamente.

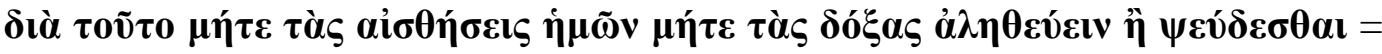
por isso, nem nossas sensações e tampouco nossas opiniões dizem-nos verdades ou mentiras.

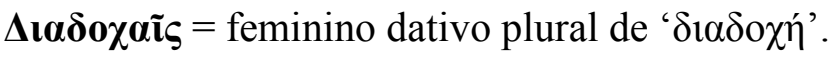

$\boldsymbol{\delta} \boldsymbol{\iota} \boldsymbol{\delta} \boldsymbol{\delta} \chi \chi \eta^{\prime}=$ sucessão

$\delta\llcorner\operatorname{\theta } \theta \varepsilon \sigma ı \varsigma$ = disposição.

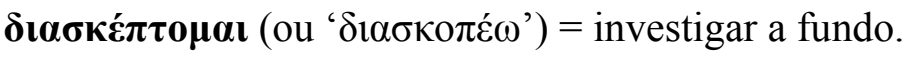

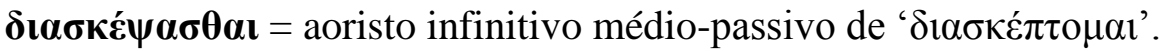

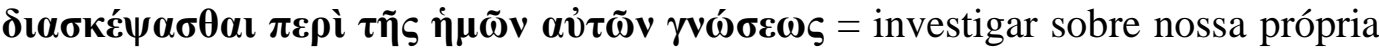
capacidade de conhecimento.

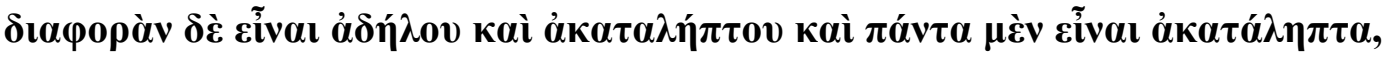

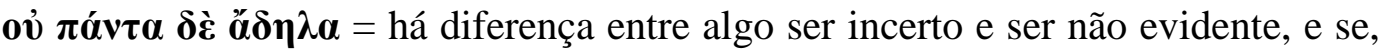
por um lado, tudo é incerto, por outro lado, nem tudo é não evidente.

$\boldsymbol{\delta} \boldsymbol{\iota} \boldsymbol{\varphi} \omega \mathbf{v} \boldsymbol{\alpha} \boldsymbol{\alpha}=$ discordância; desacordo.

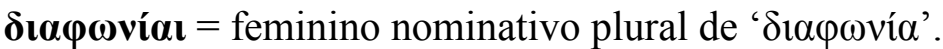




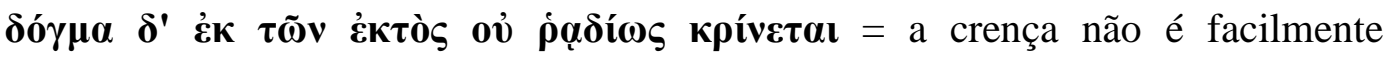
descoberta a partir de coisas externas.

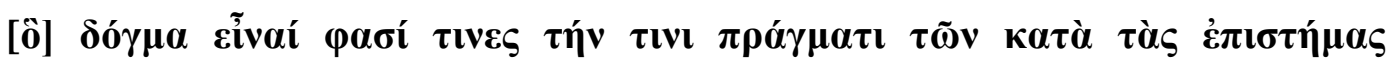

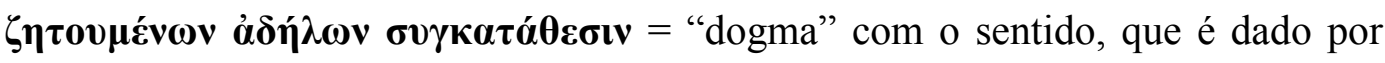
alguns, de "assentimento a alguns dos objetos não evidentes da investigação [acerca do, ou comprometida com o] conhecimento".

$\boldsymbol{\delta} \boldsymbol{\gamma} \gamma \boldsymbol{\mu} \boldsymbol{\alpha}=$ crença; opinião; decreto.

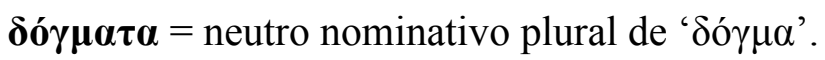

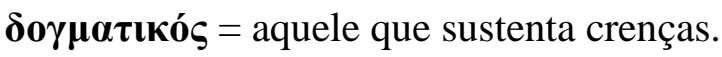

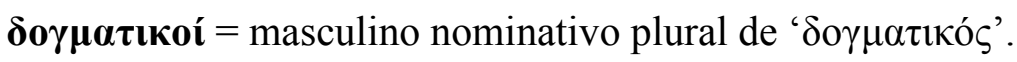

$\boldsymbol{\delta} \boldsymbol{\gamma} \gamma \boldsymbol{\mu \alpha \tau i ́ \zeta \varepsilon ı v ~ = ~ p r e s e n t e ~ i n f i n i t i v o ~ a t i v o ~ d e ~ ' \delta o \gamma \mu \alpha \tau i ́ \zeta \omega ' . ~}$

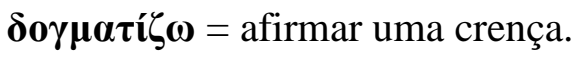

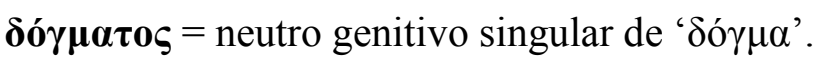

$\boldsymbol{\delta} \boldsymbol{\gamma} \gamma \boldsymbol{\mu \alpha ́} \tau \boldsymbol{\tau} \boldsymbol{v} \boldsymbol{o} \rho \boldsymbol{\theta} \tilde{\boldsymbol{\omega}} \mathbf{v}=$ de crenças corretas.

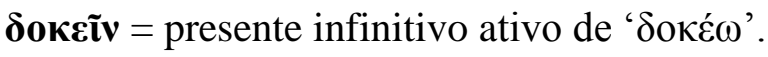

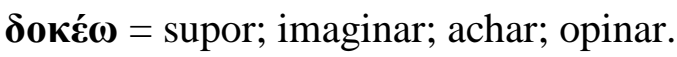

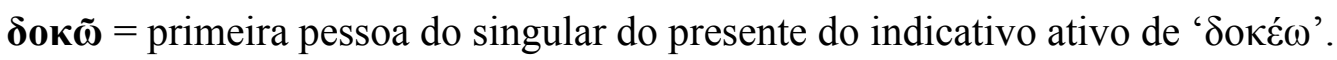

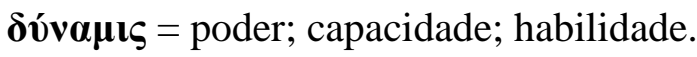

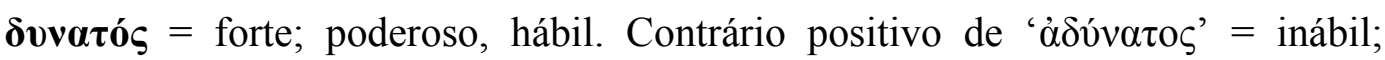
incapaz; fraco.

$\mathbf{E}$

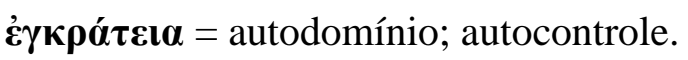

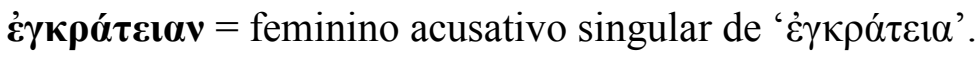

ع̋日os = costume; hábito. 


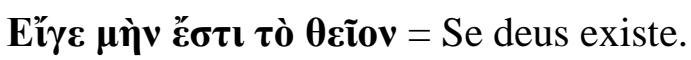

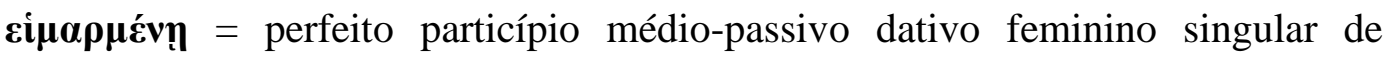
' $\mu \varepsilon i ́ p o \mu \alpha \imath '$.

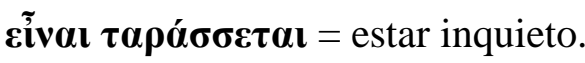

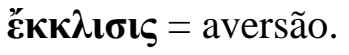

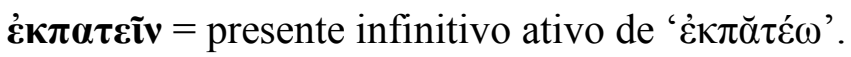

$\dot{\boldsymbol{\varepsilon} \kappa} \boldsymbol{\pi} \check{\boldsymbol{\alpha}} \tau \boldsymbol{\varepsilon} \boldsymbol{\varepsilon} \omega=$ apartar-se da sociedade.

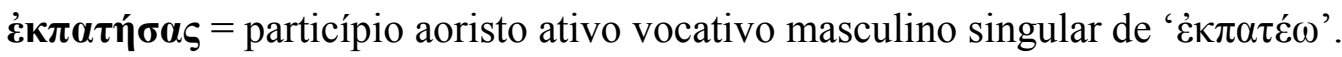

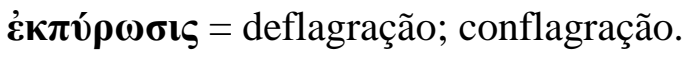

$\grave{\varepsilon} \boldsymbol{\mu} \boldsymbol{\pi} \boldsymbol{\varepsilon} \mathbf{\rho} \mathbf{\alpha} \boldsymbol{\alpha}=$ experiência.

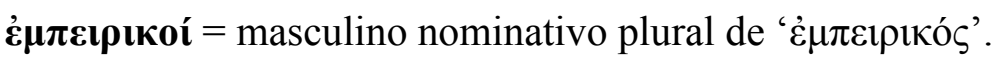

$\grave{\varepsilon} \boldsymbol{\mu} \boldsymbol{\pi} \boldsymbol{\iota} \rho \mathbf{\iota} \boldsymbol{\varsigma} \varsigma$ = de acordo com a experiência; empírico.

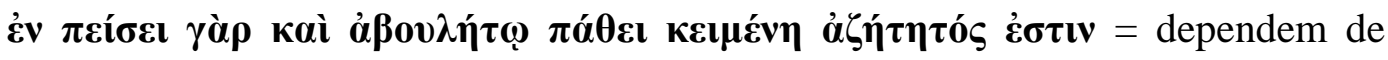
sentimentos passivos e involuntários que não estão sob investigação.

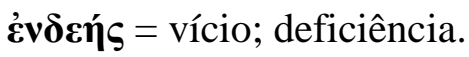

غ̇vvó $\mu \alpha=$ conceito.

غ̇vvớ $\mu \alpha \tau \alpha=$ neutro nominativo plural de 'Ẻvvó $\mu \alpha$ '.

ع̌ $\xi \mathbf{l}$ = condição permatente; coesão.

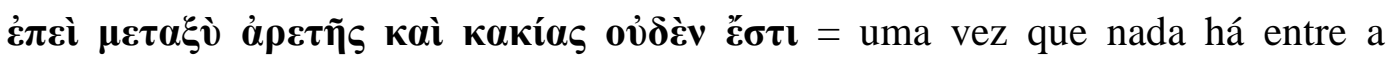
excelência e o vício.

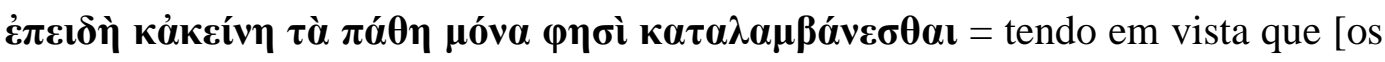
cirenaicos] asserem que somente as afecções são apreensíveis.

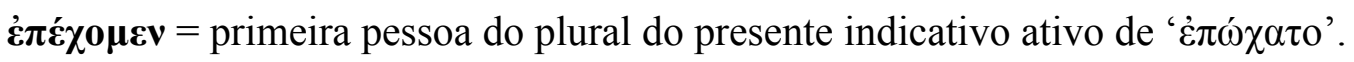

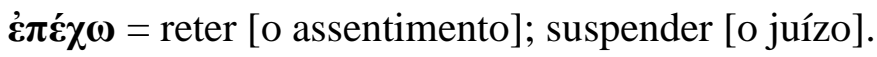




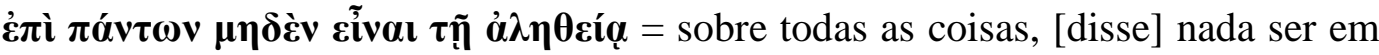
verdade.

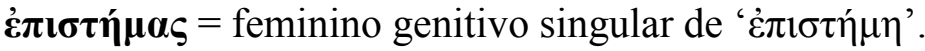

$\dot{\varepsilon} \pi \iota \tau \tau \eta ́ \mu \eta=$ entendimento científico.

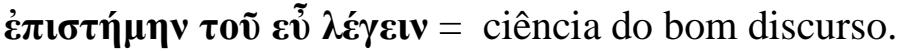

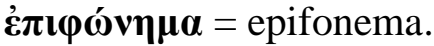

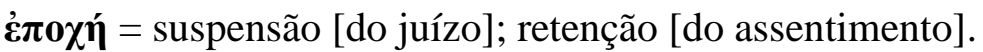

$\dot{\varepsilon} \pi \mathbf{0} \chi \tilde{\eta} \varsigma$ גó́yov = discurso da suspensão [do juízo].

$\dot{\varepsilon} \pi \omega ́ \chi \alpha \tau 0$ = impedir; obstruir.

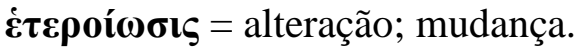

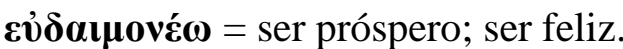

$\boldsymbol{\varepsilon v ̉ \delta \alpha \mu \rho v \eta ́ \sigma \varepsilon เ v ~ = ~ f u t u r o ~ i n f i n i t i v o ~ a t i v o ~ d e ~ ' \varepsilon v ̉ \delta \alpha \mu o v \varepsilon ́ ~} \omega$ '.

$\boldsymbol{\varepsilon} \boldsymbol{\delta} \boldsymbol{\delta} \boldsymbol{\alpha} \boldsymbol{\mu} \boldsymbol{0} \boldsymbol{v} \boldsymbol{\alpha} \boldsymbol{\alpha}$ = felicidade; prosperidade

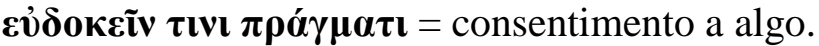

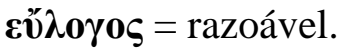

$\dot{\boldsymbol{\varepsilon}} \varphi^{\prime} \dot{\boldsymbol{\eta}} \boldsymbol{\mu} \tilde{v} \boldsymbol{v}=$ o que depende de nós.

$\mathbf{Z}$

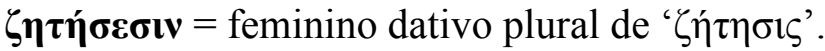

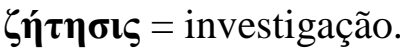

$\zeta \omega \gamma \rho \alpha \varphi i ́ \alpha=$ desenho ou pintura de animais. 


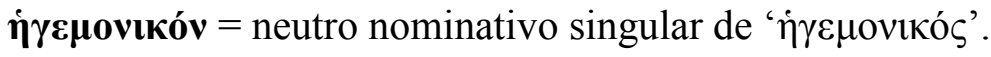

$\dot{\boldsymbol{\eta}} \gamma \varepsilon \boldsymbol{\mu} \boldsymbol{\mu v} \mathbf{i} \boldsymbol{o ́} \varsigma$ = que comanda; autoridade; líder.

$\dot{\boldsymbol{\eta}} \boldsymbol{\delta} \boldsymbol{o v} \boldsymbol{\eta}=$ prazer

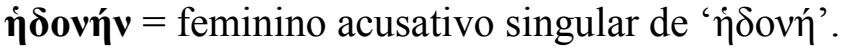

$\dot{\eta} \sigma \boldsymbol{\sigma} \chi \mathbf{i} \alpha=$ inquietude.

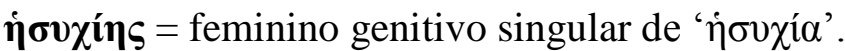

$\dot{\eta} \sigma 0 \chi \imath o ́ \tau \eta \varsigma$ = quieto.

I

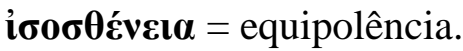

$\mathbf{K}$

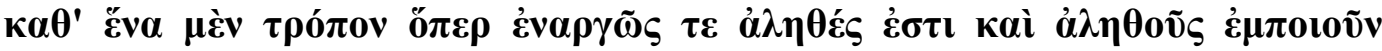

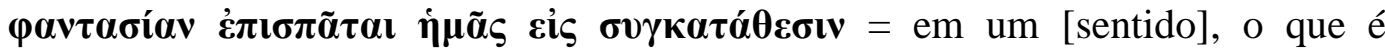
claramente verdade e que, produzindo uma visão de verdade, leva-nos ao assentimento.

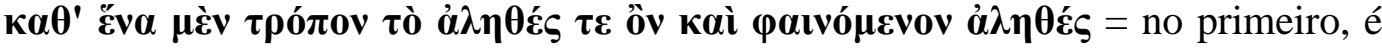
aquilo que tanto parece quanto é verdade.

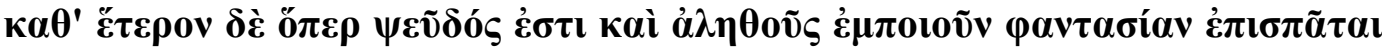

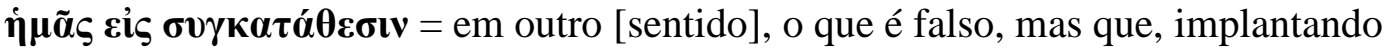
uma impressão de verdade, leva-nos ao assentimento.

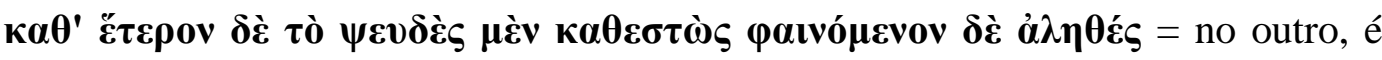
aquilo que é realmente falso, mas parece verdade.

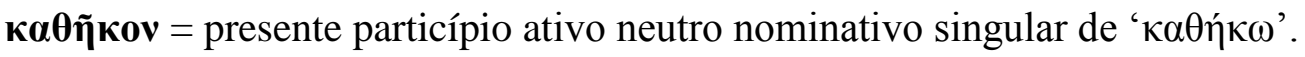

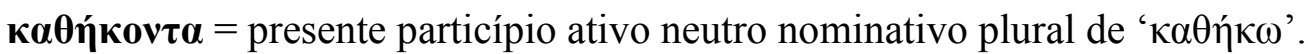


$\kappa \boldsymbol{\kappa} \theta \dot{\eta} \kappa \omega=$ agir no momento propício; agir apropriadamente; agir de modo a cumprir os deveres.

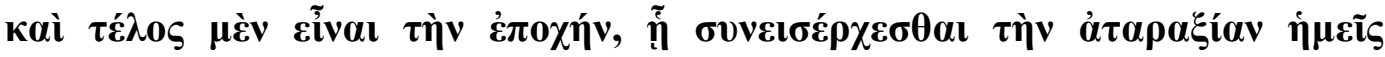

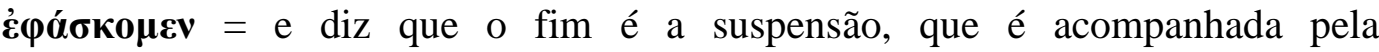
imperturbabilidade.

како́v = mal (susbstantivo).

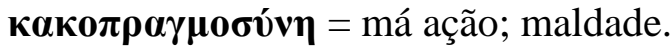

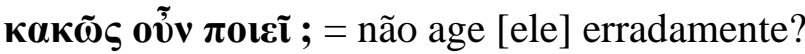

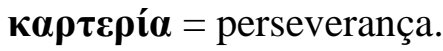

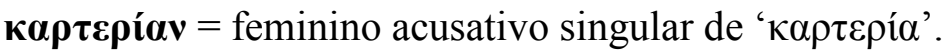

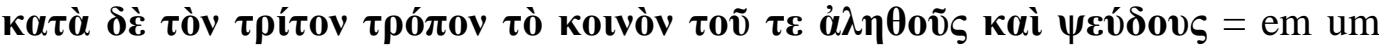
terceiro [sentido], é o que participa da verdade e da falsidade da mesma maneira.

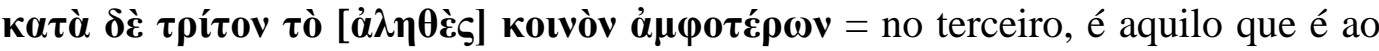
mesmo tempo tanto verdadeiro quanto falso.

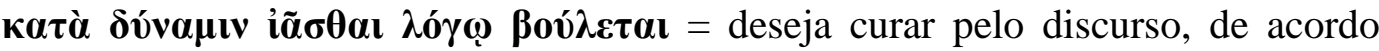
com a possibilidade.

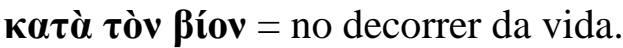

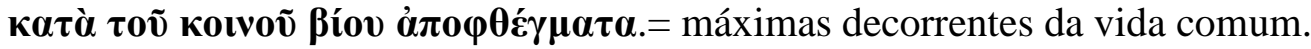

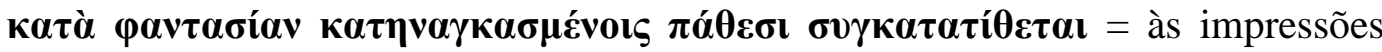
coercitivas [originadas nas] experiências sensíveis, assente.

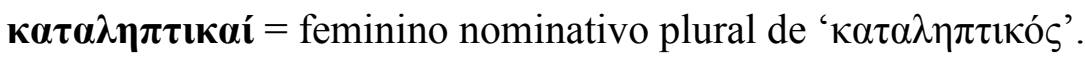

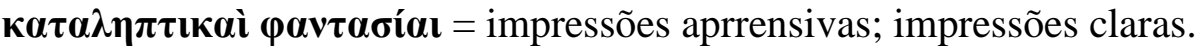

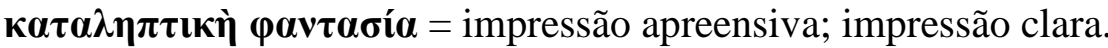

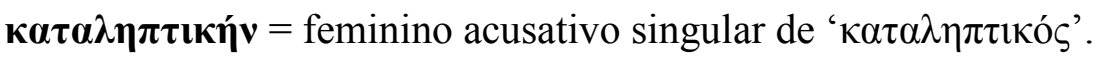

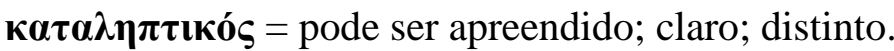




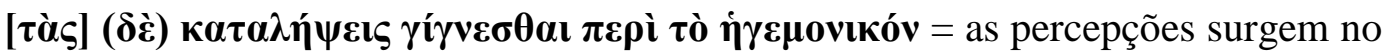
princípio comandante.

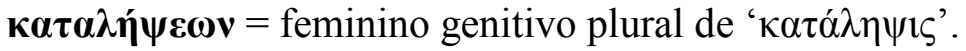

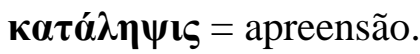

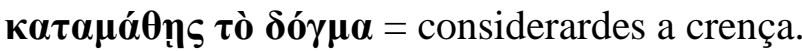

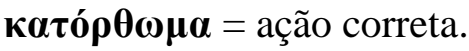

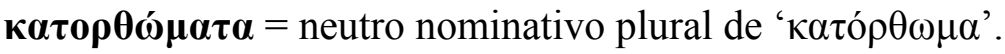

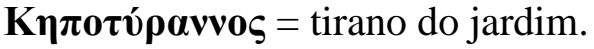

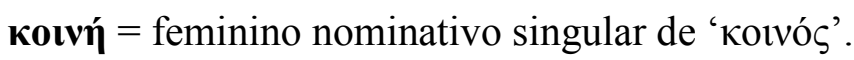

Kotvós = comum.

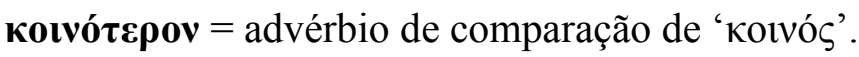

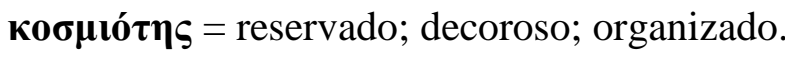

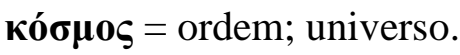

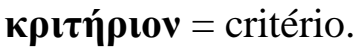

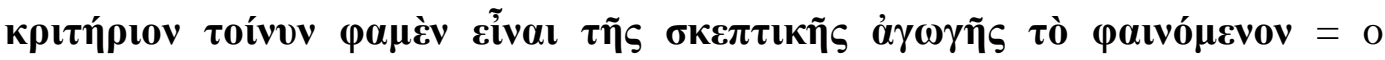
critério, então, da conduta cética é, dizemos, a aparência.

$\Lambda$

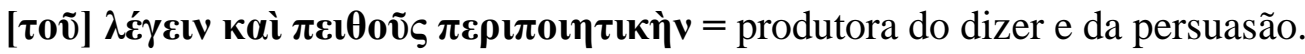

$\lambda \varepsilon \kappa \tau$ ó $=$ neutro nominativo plural de ' $\lambda \varepsilon \kappa \tau$ ó $\varsigma$ '.

$\lambda \varepsilon \kappa \tau$ ó $\varsigma$ = proferimento; algo capaz de ser dito.

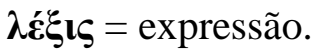

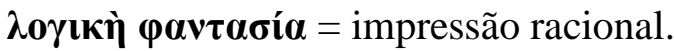

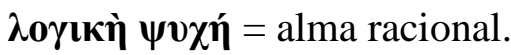


$\lambda \mathbf{\gamma} \gamma \mathbf{o} \varsigma$ = razão; discurso.

\section{M}

$\boldsymbol{\mu} \boldsymbol{\theta \theta \eta \tau} \boldsymbol{\eta} \varsigma_{\varsigma}=$ aluno; pupilo.

$\boldsymbol{\mu \alpha i ́ v o} \boldsymbol{\mu \alpha \mathbf { \imath }}=$ enfurecer-se; descontrolar-se; enlouquecer.

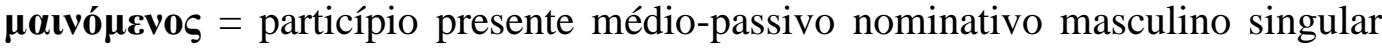
de ' $\mu \alpha i ́ v o \mu \alpha$ '.

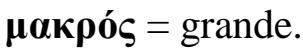

$\mu \alpha \dot{\lambda} \boldsymbol{\alpha}=$ muito.

$\mu \alpha \lambda \alpha \kappa i ́ \alpha$ = frouxidão; afetação.

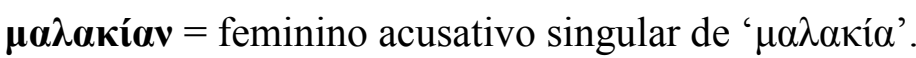

$\mu \tilde{\boldsymbol{\alpha}} \lambda \lambda \boldsymbol{\alpha}=$ mais que.

$\boldsymbol{\mu \varepsilon i ́ \rho o} \boldsymbol{\mu \alpha} \mathbf{\imath}=$ receber o seu quinhão.

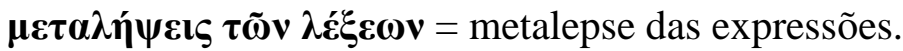

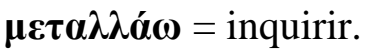

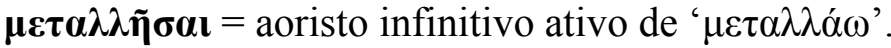

$\boldsymbol{\mu} \grave{\eta} \boldsymbol{\delta o \gamma} \boldsymbol{\mu \alpha \tau i ́ \zeta \varepsilon ı v ~ = ~ n a ̃ o ~ d o g m a t i z a . ~}$

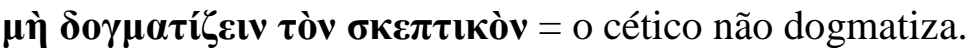

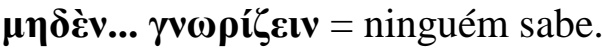

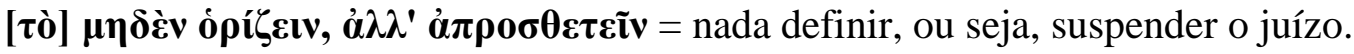

$\boldsymbol{\mu} \boldsymbol{\delta} \boldsymbol{\varepsilon} \tilde{\pi} \boldsymbol{\tau} \tau \varepsilon=$ nunca.

никрó $\varsigma$ = pequeno.

$\boldsymbol{\mu \iota \sigma \alpha v \theta \rho \omega \pi \varepsilon ́} \omega=$ rejeitar a humanidade. 
$\mu \iota \sigma \alpha v \theta \rho \omega \pi \eta ́ \mid \sigma \alpha \varsigma=$ particípio aoristo ativo nominativo masculino singular de

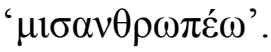

$\boldsymbol{\mu \iota \sigma \alpha v \theta \rho \omega \pi i ́ \alpha}=$ aversão à humanidade.

$\mathbf{N}$

vouoí = masculino nominativo plural de 'vó $\mu \mathrm{o} \varsigma$ '.

vó $\mu$ o $\varsigma$ = convenções; costumes.

võ̃ $\varsigma=$ mente

$\mathbf{O}$

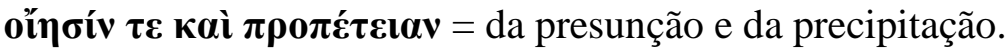

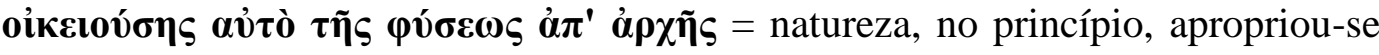
para si mesma.

oiksé́ $\omega \sigma \mathbf{t}$ = apropriação; afinidade; atração; propensão [a autopreservação, no caso do estoicismo].

ö $\boldsymbol{\lambda} \mathbf{s}=$ tudo.

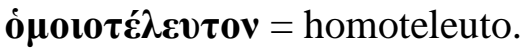

ő $\boldsymbol{\varepsilon} \xi \mathbf{ı}$ = apetição.

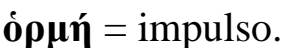

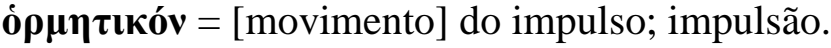

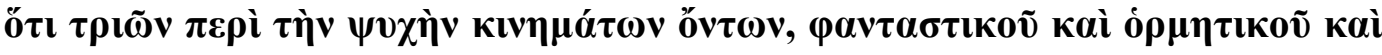

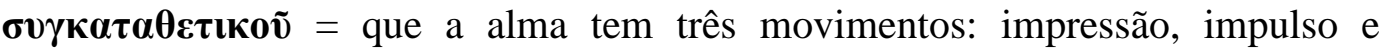
assentimento.

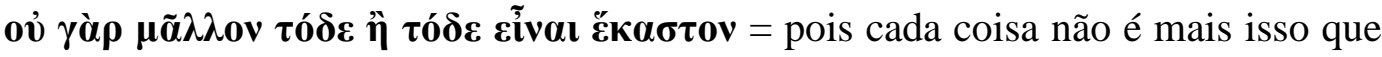
aquilo. 
$\boldsymbol{o v} \boldsymbol{\mu} \tilde{\boldsymbol{\alpha}} \lambda \lambda \boldsymbol{o v}=$ nada mais.

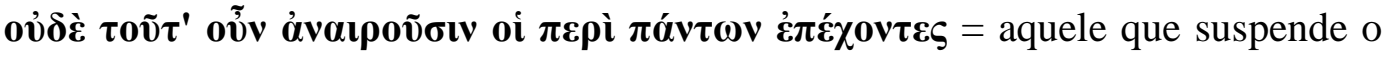
juízo sobre tudo não remove esse movimento.

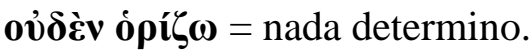

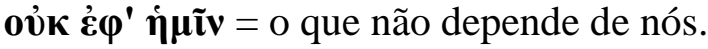

\section{П}

$\boldsymbol{\pi \alpha ́} \boldsymbol{\theta} \boldsymbol{o} \varsigma$ = acidente; incidente; sofrimento; paixão; emoção; qualquer estado passivo.

$\boldsymbol{\pi} \boldsymbol{\alpha} \boldsymbol{\delta} \boldsymbol{\varepsilon} \boldsymbol{\varepsilon} \boldsymbol{\alpha} \boldsymbol{\alpha}=$ cuidado com crianças; educação.

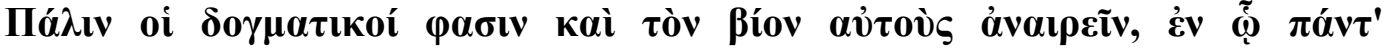

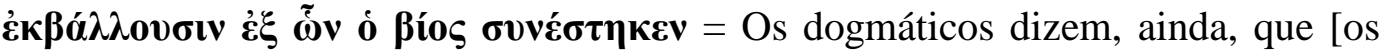
céticos] destroem a vida, ao rejeitarem todas as coisas em que a vida consiste.

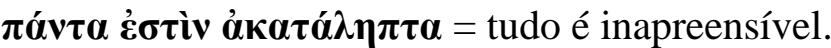

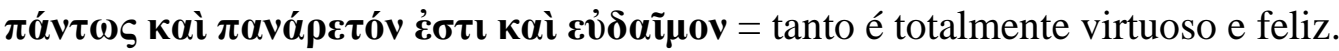

$\pi \tilde{\alpha} \varsigma=$ todo

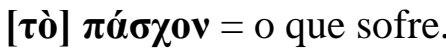

$\boldsymbol{\pi \varepsilon \mathbf { \imath } \boldsymbol { \theta } \tilde { \mathbf { v } } \varsigma}=$ feminino genitivo singular de ' $\pi \varepsilon \imath \theta \omega ́$ '.

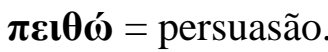

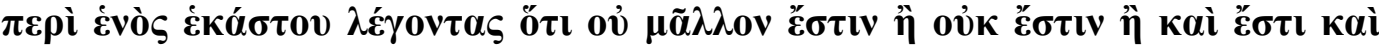

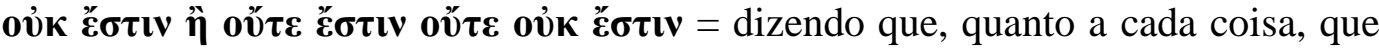
não é mais do que não é, ou que tanto é quanto não é, ou que nem é e nem não é.

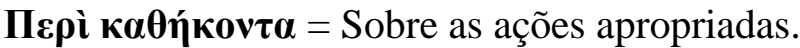

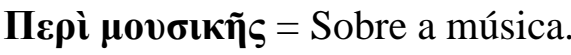




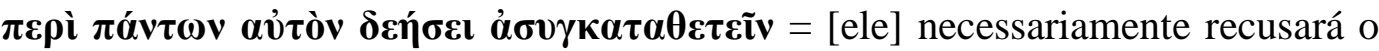
assentimento sobre tudo.

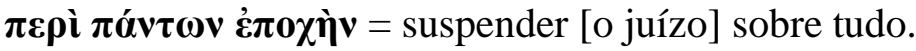

Пєрі̀

$\pi \varepsilon p i ́ o \delta o v=$ período.

$\boldsymbol{\pi} \mathbf{\imath} \boldsymbol{\theta} \alpha \mathbf{v o ́} \mathbf{v}=$ neutro nominativo singular de ' $\pi \mathrm{\imath} \theta \alpha v$ ó $\varsigma$ '.

$\boldsymbol{\pi} \mathbf{\imath} \boldsymbol{\theta \alpha} \mathbf{o} \boldsymbol{\varsigma}$ = persuasivo; provável.

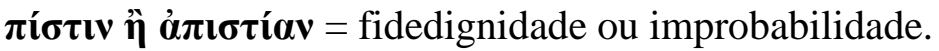

$\boldsymbol{\pi v \varepsilon \tilde { u } \mu \alpha}=$ alento; ar.

$[\tau \grave{c}] \boldsymbol{\pi 0 \iota \mathbf { v } v}=$ o que produz

$\pi \mathbf{o} \lambda \mathbf{s}=$ cidade

$\pi \mathbf{0} \boldsymbol{\nu} \boldsymbol{\mu} \boldsymbol{\alpha} \boldsymbol{\theta} \boldsymbol{\varepsilon \varepsilon \boldsymbol { \alpha }} / \boldsymbol{\pi 0 \lambda v \mu \alpha \theta i ́ \alpha}=$ muito conhecimento.

$\pi \mathbf{0} \lambda v \boldsymbol{\mu} \boldsymbol{\alpha} \boldsymbol{\theta} \dot{\eta} \varsigma$ = alguém que possui muito conhecimento.

$\pi \mathbf{0} \boldsymbol{\nu} \pi \rho \alpha \gamma \mu \boldsymbol{\mu} \boldsymbol{0} \mathbf{v \eta}=$ oficiosidade; intrometimento; curiosidade excessiva.

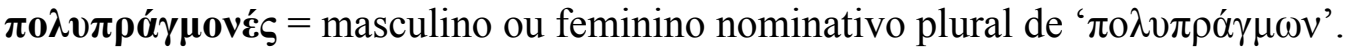

$\pi 0 \lambda v \pi \rho \alpha ́ \gamma \mu \omega v=$ oficioso; intrometido.

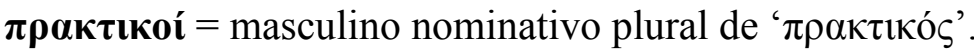

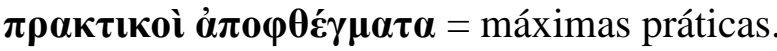

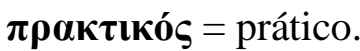

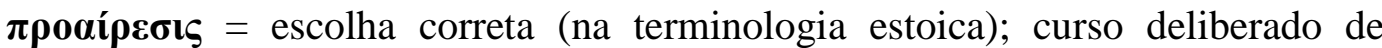
ações.

лроколи́ = progressão gradual.

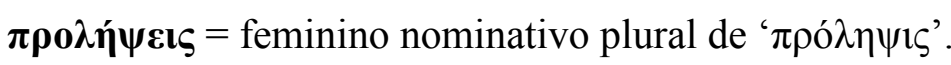

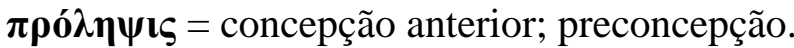




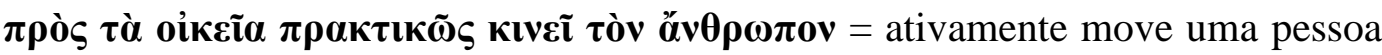
aos objetos apropriados.

$\pi \rho \boldsymbol{\pi} \boldsymbol{\varepsilon} \pi \boldsymbol{\pi} \boldsymbol{\delta} \boldsymbol{\alpha} \boldsymbol{\alpha} \boldsymbol{\alpha} \zeta \boldsymbol{\varepsilon} \mathbf{\imath}=$ terceira pessoa do singular no presente do indicativo ativo de ' $\pi \rho 0 \sigma \varepsilon \pi 1 \delta o \xi \alpha \dot{\zeta} \omega ’$.

$\pi \rho 0 \sigma \varepsilon \pi \downarrow \delta 0 \xi \boldsymbol{\alpha} \zeta \omega=$ confirmar através de aprovação.

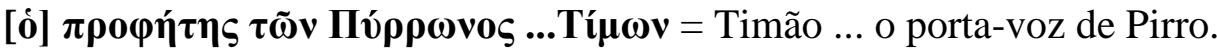

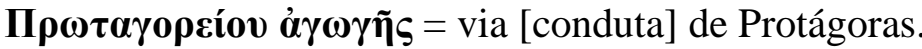

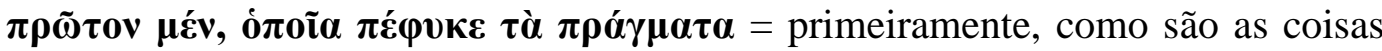
por natureza.

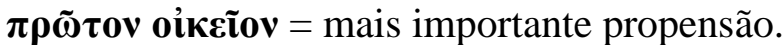

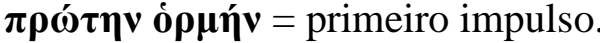

( $(\grave{\mathbf{o}}) \boldsymbol{\pi} \tilde{\mathbf{v}} \boldsymbol{\rho}=(\mathrm{o})$ fogo.

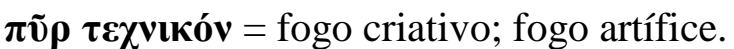

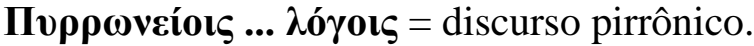

Пvөауорика́ = 'Sobre Pitágoras'.

$\Sigma$

$\boldsymbol{\sigma} \mathbf{\lambda} \lambda \lambda \mathbf{o} \varsigma$ = poema satírico.

$\boldsymbol{\Sigma} \mathbf{i} \lambda \lambda \mathbf{o l}=$ masculino nominativo plural de ' $\sigma i ́ \lambda \lambda o \varsigma^{\prime}$.

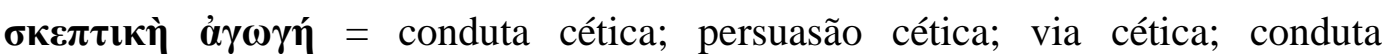
investigativa.

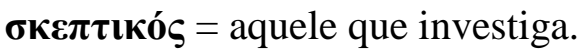

$\boldsymbol{\sigma \kappa \varepsilon ́} \pi \tau \mathbf{\mu \alpha \boldsymbol { \alpha }}=$ investigar; ver argutamente.

$\boldsymbol{\sigma \kappa \varepsilon ́} \psi \mathbf{l} \varsigma$ = investigação. 
$\boldsymbol{\sigma \kappa о \pi \boldsymbol { \alpha } \omega}=$ investigar; examinar.

$\boldsymbol{\sigma \kappa о \pi \varepsilon \tilde { \mathbf { v } } = \text { presente infinitivo ativo de ' } \sigma \kappa о \pi \alpha ́ \omega}$ '.

$\boldsymbol{\sigma o \varphi} \mathbf{i} \boldsymbol{\alpha}=$ sabedoria.

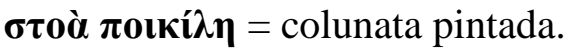

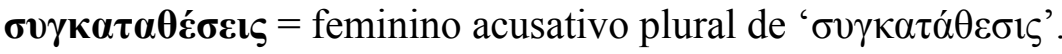

$\boldsymbol{\sigma v} \gamma \kappa \boldsymbol{\alpha} \tau \boldsymbol{\alpha} \boldsymbol{\alpha} \boldsymbol{\varepsilon} \boldsymbol{\sigma} \iota \varsigma$ = assentimento; aprovação.

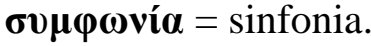

$\boldsymbol{\sigma v v} \boldsymbol{\theta \varepsilon \varepsilon \boldsymbol { \alpha }}=$ ação habitual; hábito; costume.

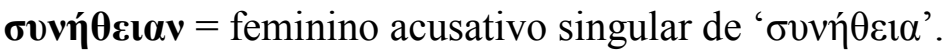

$\boldsymbol{\sigma} \chi \boldsymbol{\alpha} \boldsymbol{\lambda} \boldsymbol{\alpha} \mathbf{i}=$ feminino nominativo plural de ' $\sigma \chi 0 \lambda \eta ் '$.

$\boldsymbol{\sigma} \chi \mathbf{0} \lambda \hat{\eta}=$ escola; produto ou lugar de estudo.

$\boldsymbol{\sigma \omega \rho i ́} \tau \eta \varsigma$ = sorites; argumento do monte.

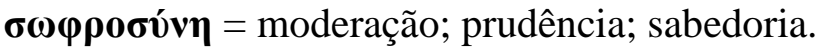

$\mathbf{T}$

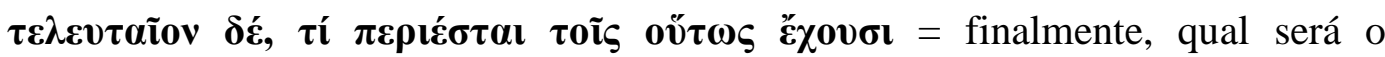
resultado para aqueles que têm essa atitude.

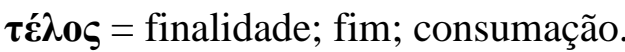

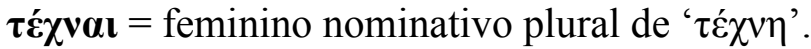

$\boldsymbol{\tau} \dot{\varepsilon} \chi \boldsymbol{v} \boldsymbol{\alpha} \varsigma=$ feminino acusativo plural de ' $\tau \dot{\varepsilon} \chi \nu \eta$ '.

$\tau \boldsymbol{\varepsilon}_{\chi} \chi \mathbf{v} \eta \lambda \hat{\gamma} \gamma \omega \mathbf{v}=$ arte do discurso.

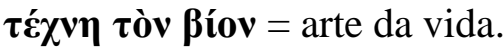

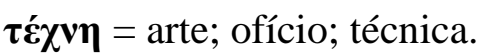


$\boldsymbol{\tau} \dot{\varepsilon} \chi \mathbf{v} \eta \mathbf{v}=$ feminino acusativo singular de ' $\tau \dot{\varepsilon} \chi \nu \eta$ '.

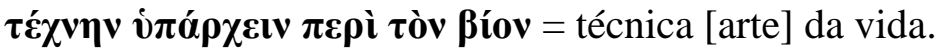

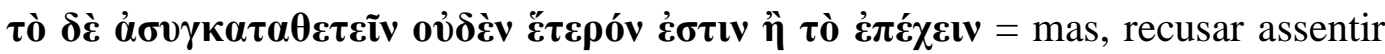
não é nada além de suspender o juízo.

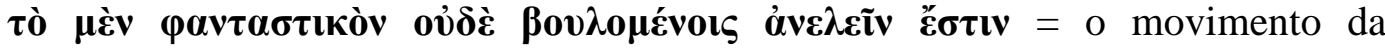
impressão não podemos remover.

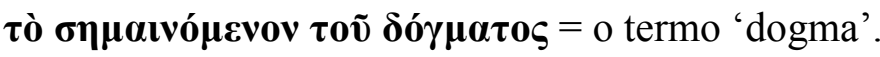

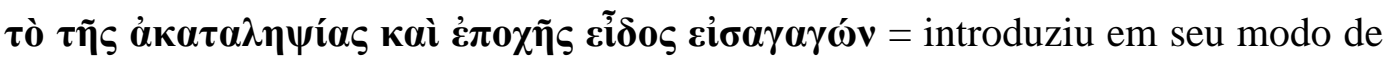
vida os estados de inapreensibilidade e de suspensão.

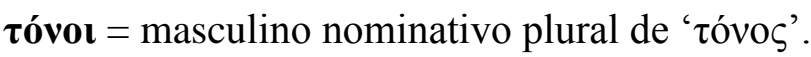

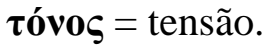

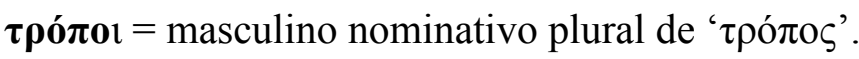

$\tau \rho o ́ \pi \mathbf{s} \varsigma$ modo [de argumentação].

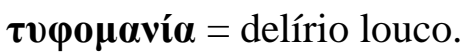

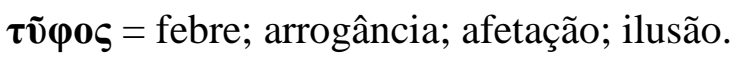

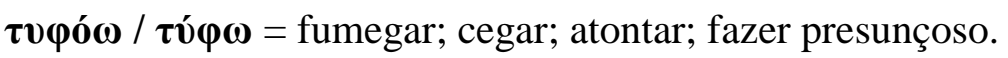

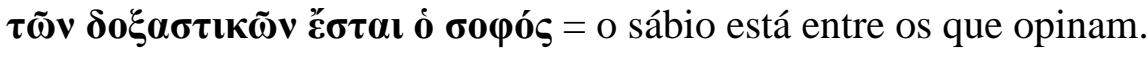

$\mathbf{Y}$

vँßpıs = violência ; insolência.

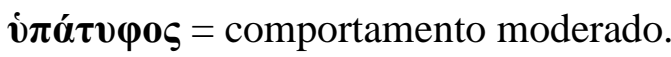

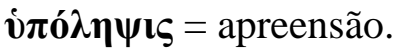

$\Phi$ 


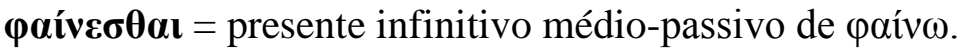

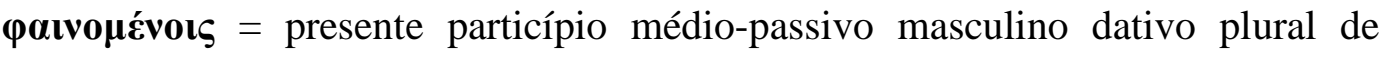

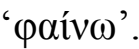

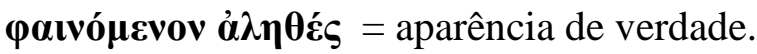

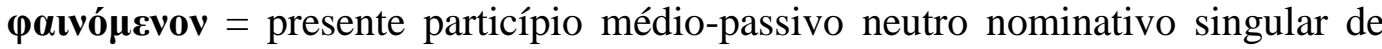

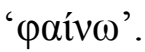

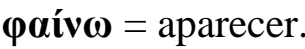

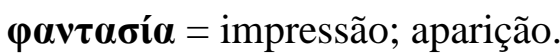

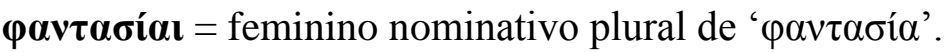

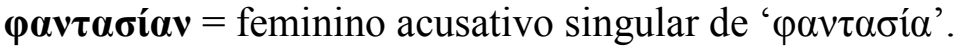

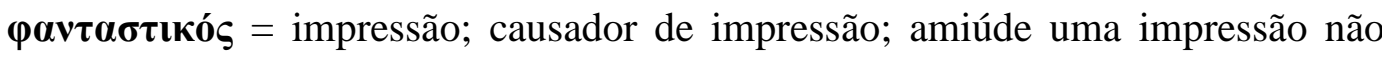
confiável, fruto de delírio, por exemplo.

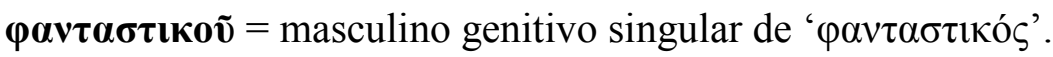

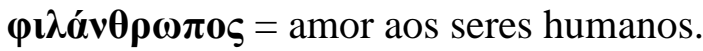

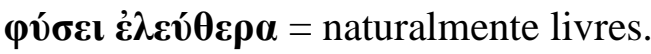

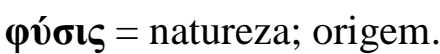

$\mathbf{X}$

$\chi \rho \varepsilon \varepsilon ́ \alpha=$ máxima

$\chi \rho \varepsilon \tilde{\boldsymbol{i} \alpha \mathbf{l}}=$ feminino nominativo plural de ' $\chi \rho \varepsilon \boldsymbol{i}^{\alpha} \alpha$ '.

$\Psi$

$\boldsymbol{\psi v} \chi \boldsymbol{\eta}^{\prime}=$ vida; alma 
$\Omega$

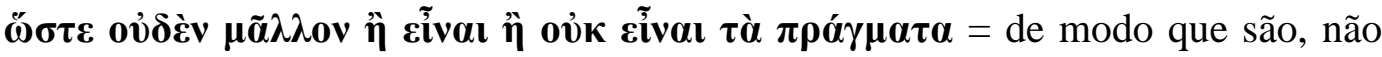
mais do que não são, as coisas efetivas (tradução de Cassin, op. cit.). 


\section{Anexo: quadros conceituais e tábua cronológica}

\subsection{Quadro conceitual da filosofia estoica}

No quadro conceitual abaixo tentamos relacionar entre si as partes do sistema estoico, bem como suas principais teses.

\begin{tabular}{|c|c|c|c|c|}
\hline \multirow{4}{*}{$\begin{array}{c}* \text { Física. } \\
\rightarrow \\
\downarrow\end{array}$} & \multirow{4}{*}{$\begin{array}{c}\text { Deus }= \\
\text { naturez.a } \\
\rightarrow \\
\downarrow\end{array}$} & \multirow{4}{*}{ 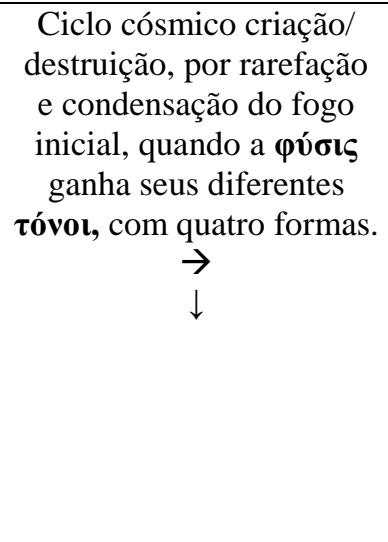 } & 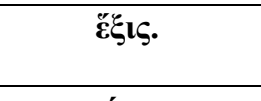 & $\begin{array}{c}=\text { Coesão (todos os } \\
\text { corpos). }\end{array}$ \\
\hline & & & 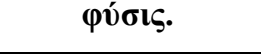 & = Vegetais. \\
\hline & & & 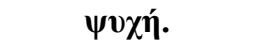 & $=$ Animais \\
\hline & & & $\begin{array}{c}\lambda \mathbf{\gamma} \gamma \mathbf{\iota} \boldsymbol{\eta} \\
\text { (capacidade de } \\
\text { (capán } \\
\text { distinguir entre } \\
\downarrow)\end{array}$ & 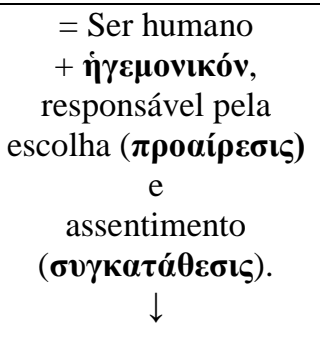 \\
\hline \multirow{3}{*}{$\begin{array}{c}* \text { Teoria do } \\
\text { conhecimento. } \\
\rightarrow \\
\downarrow\end{array}$} & \multirow{3}{*}{$\begin{array}{l}\text { Compreender } \\
\text { os desígnios } \\
\text { divinos (a } \\
\text { verdade e as } \\
\text { cadeias } \\
\text { causais). } \\
\rightarrow \\
\downarrow\end{array}$} & \multirow{3}{*}{ 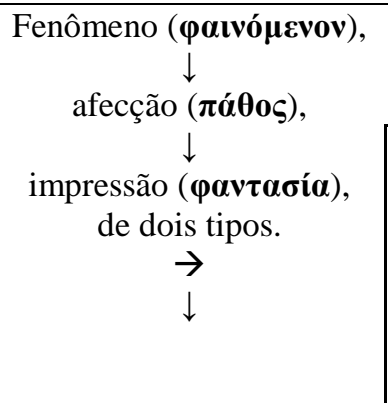 } & $\begin{array}{c}\text { 1-catalépticas } \\
(\kappa \boldsymbol{\alpha} \boldsymbol{\alpha} \lambda \boldsymbol{\eta} \boldsymbol{\pi} \tau \mathbf{u} \boldsymbol{\alpha}) \\
\rightarrow \\
\rightarrow\end{array}$ & \multirow{3}{*}{$\begin{array}{c}+ \\
\text { escolha de assentir }= \\
\text { verdade } \\
\downarrow\end{array}$} \\
\hline & & & 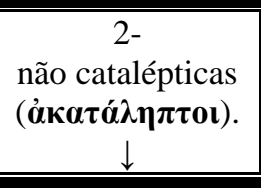 & \\
\hline & & & $\begin{array}{c}\text { Como conhecer? } \\
\downarrow\end{array}$ & \\
\hline \multirow[t]{3}{*}{ *Ética. } & \multirow{3}{*}{$\begin{array}{c}\text { Viver } \\
\text { conforme a } \\
\text { natureza = } \\
\text { conforme os } \\
\text { desígnios } \\
\text { divinos. } \rightarrow\end{array}$} & $\begin{array}{c}\text { Aceitação do destino } \\
(\boldsymbol{\varepsilon i} \boldsymbol{\mu} \boldsymbol{\alpha} \boldsymbol{\mu} \boldsymbol{\mu} \mathbf{\varepsilon} \boldsymbol{\eta}) \text {, resignação, } \\
\text { compreensão de seu papel }\end{array}$ & $\begin{array}{c}\text { Como agir? } \\
\downarrow\end{array}$ & \multirow{3}{*}{ 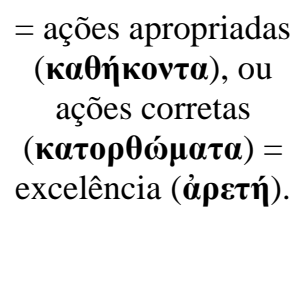 } \\
\hline & & no cosmos. & $?$ & \\
\hline & & $\rightarrow$ & $\rightarrow$ & \\
\hline
\end{tabular}




\subsection{Quadros conceituais do ceticismo antes de Sexto Empírico}

Relacionamos abaixo em quadros conceituais as etapas do ceticismo antes de Sexto Empírico que tratamos, uma por tabela. Desse modo, em "fase" explicitamos a etapa, conforme os capítulos ("Protoceticismo"; " "Vida de Pirro' em D.L."; "Sucessores de Pirro"; “Arcesilao", "Carnéades", "Clitômaco, Filo, Antíoco, Enesidemo e Agripa", bem como a penetração na medicina); em "fontes" indicamos as fontes que usamos; "quem" refere-se ao sujeito citado pelas fontes; "âmbitos" denota em quais sentidos os sujeitos citados podem ser entendidos como tendo uma postura cética; em seguida, aparecem as "críticas" feitas a esses âmbitos, bem como suas fontes; também demonstramos, quando houver, os "problemas das fontes", decorrentes das suas interpretações.

Ademais, quando os argumentos que aparecem nas "críticas" ou "problemas" vierem precedidos por um asterisco $(*)$, isso indica que os argumentos são contemporâneos nossos, e não daqueles a quem se dirigem.

\begin{tabular}{|c|c|c|c|c|}
\hline Fase: & Fontes: & Quem: & Âmbitos: & Críticas: \\
\hline $\begin{array}{c}\text { 1- } \\
\text { Protoceticismo } \\
\text { (ceticismo como } \\
\text { postura } \\
\text { parcialmente } \\
\text { presente mesmo } \\
\text { em filósofos } \\
\text { dogmáticos): }\end{array}$ & $\frac{\text { D.L. IX, }}{\underline{71 .}}$ & a) Homero: & $\begin{array}{c}\text { Percepção da } \\
\text { ambiguidade dos } \\
\text { sentidos e do } \\
\text { comportamento dos } \\
\text { seres humanos. }\end{array}$ & $\mathrm{X}$ \\
\hline Idem & $\underline{\text { Idem }}$ & b) Arquíloco: & Idem & $X$ \\
\hline Idem & Idem & c) Eurípedes: & Idem & $\mathrm{X}$ \\
\hline Idem & $\frac{\text { D.L. IX, }}{\underline{71-74 .}}$ & d) Xenófanes: & $\begin{array}{c}\dot{\alpha} \boldsymbol{\pi} \boldsymbol{\pi} \boldsymbol{\rho} \mathbf{\alpha} \boldsymbol{\alpha} \text { quanto aos } \\
\text { mitos e a possibilidade } \\
\text { do conhecimento. }\end{array}$ & $\mathrm{X}$ \\
\hline
\end{tabular}




\begin{tabular}{|c|c|c|c|c|}
\hline Idem & $\begin{array}{r}\frac{I d e m+}{\text { P.H. I. }} \\
\underline{210-220 .}\end{array}$ & e) Heráclito: & $\begin{array}{c}\text { ḋंopía quanto a } \\
\text { possibilidade do } \\
\text { conhecimento + } \\
\text { percepção da dubiedade } \\
\text { das coisas. }\end{array}$ & 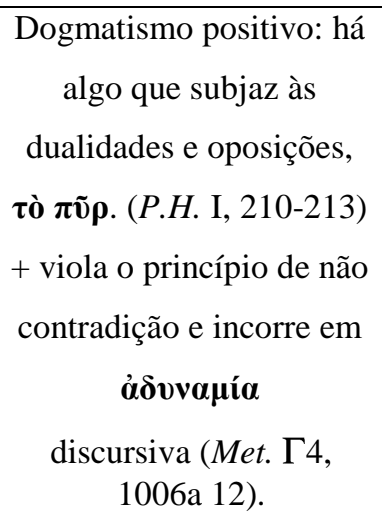 \\
\hline Idem & $\underline{I d e m}$ & $\begin{array}{l}\text { f) Zenão de } \\
\text { Eléia: }\end{array}$ & $\begin{array}{l}\dot{\alpha} \pi \mathbf{\rho} \operatorname{cí}^{\alpha} \text { quanto ao } \\
\text { movimento. }\end{array}$ & $\mathrm{X}$ \\
\hline Idem & $\underline{\text { Idem }}$ & g) Empédocles: & 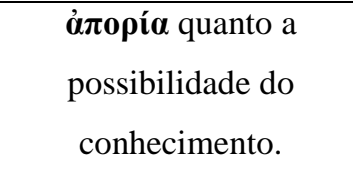 & $X$ \\
\hline Idem & $\begin{array}{c}\frac{I d e m+}{\text { P.H. I, }} \\
210-220 .\end{array}$ & h) Demócrito: & $\begin{array}{c}\text { Tudo se dá por } \\
\text { convenção + percepção } \\
\text { da dubiedade das } \\
\text { sensações + fórmula oỏ } \\
\boldsymbol{\mu} \tilde{a} \lambda \lambda \boldsymbol{\lambda o v} .\end{array}$ & $\begin{array}{l}\text { Dogmatismo positivo: } \\
\text { uso da fórmula ov̉ } \\
\mu \tilde{\alpha} \lambda \lambda \boldsymbol{o v} \text { para indicar que a } \\
\text { verdade é atômica e está } \\
\text { no micro. (P.H. I, 213- } \\
\text { 215). }\end{array}$ \\
\hline Idem & $\frac{P . H . I,}{210-220 .}$ & $\begin{array}{c}\text { i) Protágoras (e } \\
\text { Górgias?): }\end{array}$ & Relativismo. & 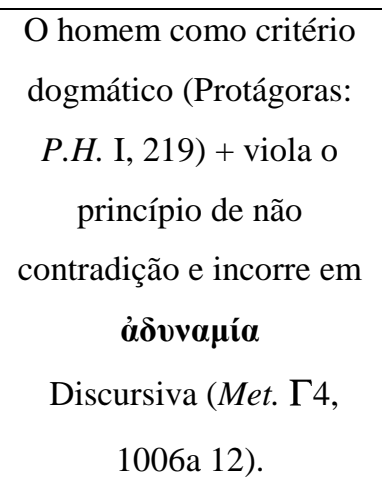 \\
\hline Idem & $\underline{I d e m}$ & j) Cirenaísmo: & 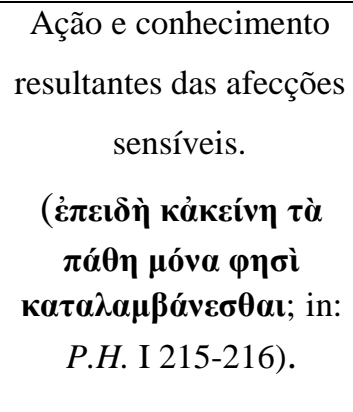 & 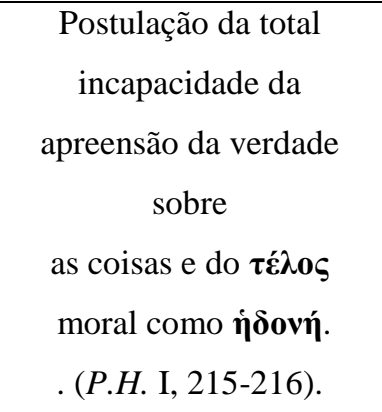 \\
\hline
\end{tabular}

\begin{tabular}{|c|c|c|c|c|c|}
\hline Fase: & Fontes: & Quem: & $\underline{\text { Âmbitos: }}$ & Críticas: & Problemas das fontes: \\
\hline
\end{tabular}




\begin{tabular}{|c|c|c|c|c|c|}
\hline $\begin{array}{c}\text { 'Vida } \\
d e \\
\text { Pirro': }\end{array}$ & $\begin{array}{l}\frac{\text { Apolodoro }}{(\text { in: D.L. IX }} \\
\underline{61) .}\end{array}$ & Pirro: & $\begin{array}{l}\text { Vida comum: Pirro } \\
\text { ativo em uma } \boldsymbol{\tau} \varepsilon \dot{\chi} \chi \mathbf{v} \eta\end{array}$ & $X$ & $\begin{array}{l}* \text { Tardio (cerca de } 120 \\
\text { anos posterior a Pirro). }\end{array}$ \\
\hline Idem & $\begin{array}{l}\text { Ascânio de } \\
\text { Abdera (in: } \\
\text { D.L. IX, 61). }\end{array}$ & Idem & $\begin{array}{c}\dot{\alpha} \kappa \alpha \tau \alpha \lambda \eta \psi i ́ \alpha+ \\
\dot{\varepsilon} \pi 0 \chi \eta ́\end{array}$ & $X$ & $\begin{array}{c}* \text { Vocabulário estoico } \\
\text { ou, pelo menos, surgido } \\
\text { no debate academia X } \\
\text { Stoá. }\end{array}$ \\
\hline Idem & $\underline{\text { Idem }}$ & Idem & 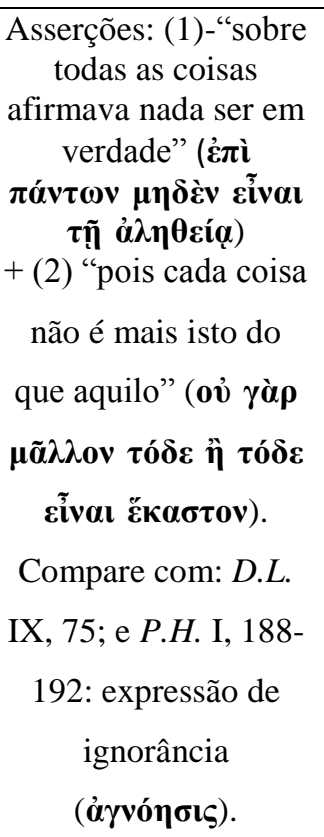 & $\begin{array}{l}\text { * Dogmatismo } \\
\text { negativo de } \\
\text { inspiração } \\
\text { atomista. }\end{array}$ & $\mathrm{X}$ \\
\hline Idem & $\begin{array}{l}\text { Antígono de } \\
\text { Caristo (in: } \\
\text { D.L. IX, 62). }\end{array}$ & Idem & $X$ & $\begin{array}{l}\dot{\alpha} \tau \alpha \rho \alpha \xi \dot{i} \alpha= \\
\dot{\alpha} \pi \rho 0 o ́ \rho \alpha \tau o \xi .\end{array}$ & $\begin{array}{c}\text { * Interesse em } \\
\text { depreciar a viabilidade } \\
\text { prática da filosofia de } \\
\text { Pirro. }\end{array}$ \\
\hline Idem & $\begin{array}{l}\frac{\underline{\text { Idem (in: }}}{\text { D.L. IX, 62- }} \\
\underline{63) .}\end{array}$ & Idem & 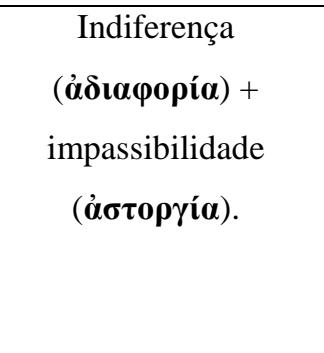 & 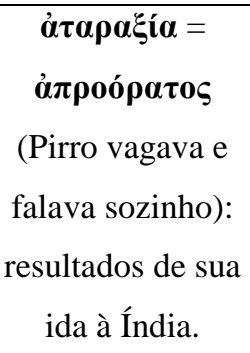 & * Idem \\
\hline Idem & $\begin{array}{l}\frac{\text { Enesidemo }}{\text { de Cnossos }} \\
\frac{\text { (in: D.L. IX, }}{\underline{62) .}}\end{array}$ & Idem & 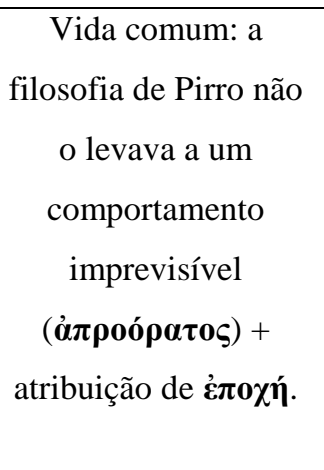 & $\bar{X}$ & $\begin{array}{c}\text { * Tardio + interesse em } \\
\text { enaltecer Pirro + } \\
\text { incorporação de um } \\
\text { vocabulário ( }(\dot{\boldsymbol{\varepsilon}} \boldsymbol{\pi} \mathbf{0} \chi \mathfrak{\eta}) \\
\text { adquirido no debate da } \\
\text { academia X Stoá para } \\
\text { retroativamente } \\
\text { entender a vida/filosofia }\end{array}$ \\
\hline
\end{tabular}




\begin{tabular}{|c|c|c|c|c|c|}
\hline & & & & & de Pirro. \\
\hline Idem & $\begin{array}{l}\text { Nausífanes } \\
\underline{\text { (em todo o }} \\
\text { passo D.L. } \\
\underline{\mathrm{IX}, 64 ?) .}\end{array}$ & Idem & 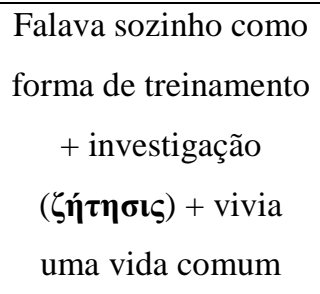 & $X$ & X \\
\hline Idem & $\begin{array}{l}\frac{\text { Timão (no }}{\text { fim D.L. IX, }} \\
\frac{64 ? \mathrm{E} \mathrm{em}}{\text { D.L. IX, 65- }} \\
\underline{66) .}\end{array}$ & Idem & 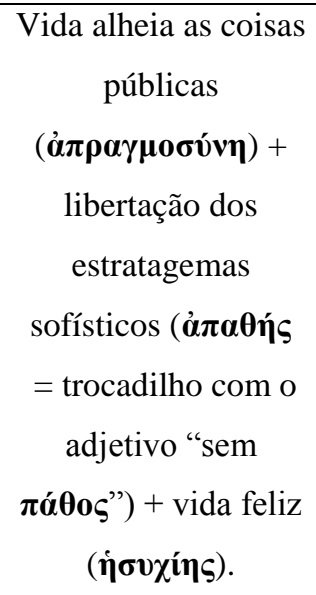 & $X$ & $X$ \\
\hline Idem & $\begin{array}{c}\frac{\text { Erastóstenes }}{\text { de Cirene }} \\
\underline{\text { (In: D.L. IX, }} \\
\underline{65-66) .}\end{array}$ & Idem & 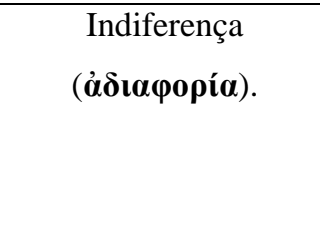 & $\begin{array}{c}\text { Indiferença } \\
\text { excessiva e } \\
\text { impossível na } \\
\text { prática. }\end{array}$ & $X$ \\
\hline Idem & $\begin{array}{l}\text { Posidônio de } \\
\text { Rodes (In: } \\
\text { D.L. IX, 68) }\end{array}$ & Idem & 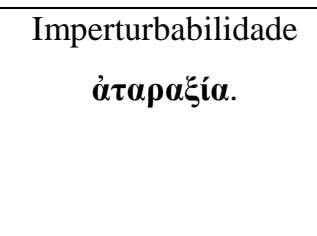 & $\mathrm{X}$ & $\begin{array}{c}\text { * Atribui } \\
\text { retroativamente um } \\
\text { vocabulário posterior a } \\
\text { Pirro. }\end{array}$ \\
\hline
\end{tabular}

\begin{tabular}{|c|c|c|c|c|c|}
\hline Fase: & Fontes: & Quem: & Âmbitos: & Críticas: & $\begin{array}{c}\text { Problemas das } \\
\text { fontes: }\end{array}$ \\
\hline $\begin{array}{c}\text { Os } \\
\text { sucessores } \\
\text { de Pirro: }\end{array}$ & $\frac{\frac{\text { D.L. IX, }}{69-70 .}}{\underline{n^{2}}}$ & $\mathbf{X}$ & $\begin{array}{l}\text { Formação da } \boldsymbol{\sigma \kappa \varepsilon \boldsymbol { \tau } \tau \boldsymbol { \tau } \mathbf { \eta }} \\
\dot{\boldsymbol{\alpha}} \boldsymbol{\gamma} \boldsymbol{\omega} \boldsymbol{\gamma} \boldsymbol{\eta} \\
\text { Entes mesmo de } \\
\text { Enesidemo de Cnossos. }\end{array}$ & $\mathrm{X}$ & $\begin{array}{c}*(1) \\
\text { Anacronismo. } \\
\text { (2) Não havia } \\
\text { homogeneidade } \\
\text { entre os } \\
\text { sucessores }\end{array}$ \\
\hline
\end{tabular}




\begin{tabular}{|c|c|c|c|c|c|}
\hline & & & & & $\begin{array}{l}\text { (Teodósio, in: } \\
\text { D.L. IX, 70). }\end{array}$ \\
\hline Idem & $\begin{array}{c}\underline{P E .} \\
14.18 .1-5 .\end{array}$ & $\mathbf{X}$ & $\begin{array}{l}\text { Ceticismo como } \\
\text { filosofia escolar. }\end{array}$ & $\mathrm{X}$ & 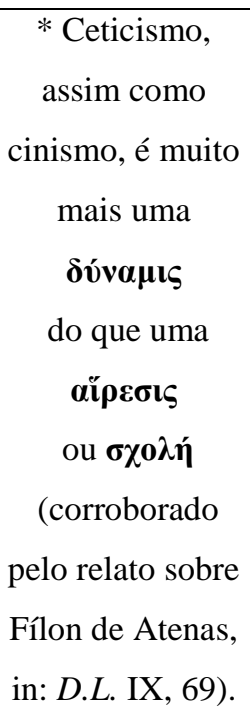 \\
\hline Idem & $\frac{\text { D.L. IX. }}{\underline{64 .}}$ & Nausífanes: & 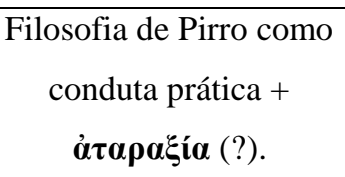 & $X$ & $X$ \\
\hline Idem & $\frac{\text { D.L. IX, }}{6 \underline{68 .}}$ & Euríloco: & Belicosidade & $\mathrm{X}$ & $\mathrm{X}$ \\
\hline Idem & $\frac{\text { D.L. IX. }}{\underline{67 .}}$ & $\begin{array}{l}\text { Fílon de } \\
\text { Atenas: }\end{array}$ & 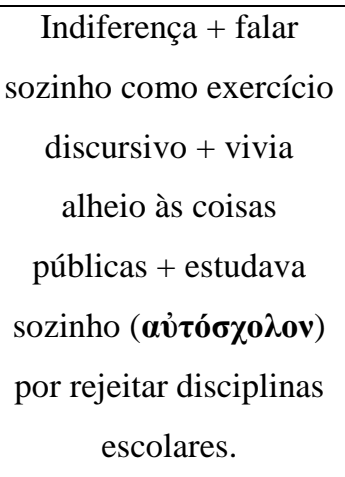 & $\mathrm{X}$ & $\mathrm{X}$ \\
\hline Idem & $\frac{\text { D.L. IX. }}{\underline{68 .}}$ & Numênio & $?$ & $?$ & $?$ \\
\hline Idem & $\begin{array}{l}\frac{\text { D.L. IX, }}{61,69 .} \\
\underline{\text { Isi.et }} \\
\underline{\text { Osi., 9; }} \\
\underline{\text { Antiq. }} \\
\underline{\text { Jud., I. }} \\
\underline{\text { vii,2; }} \\
\underline{\text { Contr. }} \\
\underline{\text { Apion., }}\end{array}$ & $\begin{array}{c}\text { Hecateu/ } \\
\text { Ascânio de } \\
\text { Abdera (a } \\
\text { mesma } \\
\text { pessoa?, ver: } \\
\text { 'DECLEVA } \\
\text { CAIZZI, F. } \\
\text { (org.). } \\
\text { Pirrone } \\
\text { testimonianz }\end{array}$ & $\begin{array}{c}\text { Estudos de diferentes } \\
\text { culturas + filosofia } \\
\text { como prática. }\end{array}$ & $\mathrm{X}$ & $\mathrm{X}$ \\
\hline
\end{tabular}




\begin{tabular}{|c|c|c|c|c|c|}
\hline & $\underline{1,22 .}$ & $\begin{array}{c}\text { e. Nápoles: } \\
\text { Bibliopolis, } \\
\text { 1981): }\end{array}$ & & & \\
\hline Idem & $\begin{array}{l}\underline{\text { Aristócles, }} \\
\frac{\text { apud. PE. }}{14.18 .1-5 ;} \\
\underline{\text { D.L. IX. }} \\
\underline{64-65,67,} \\
\underline{69,72,76,} \\
\underline{102,104-} \\
\underline{105,107 ;} \\
\underline{\text { Adv. }} \\
\underline{\text { Gram. 53. }}\end{array}$ & $\begin{array}{l}\text { Timão de } \\
\text { Fliunte: }\end{array}$ & 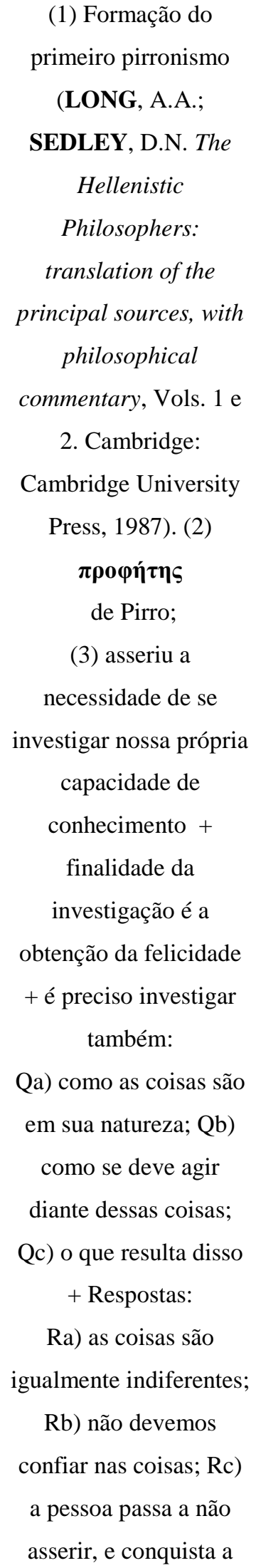 & $\begin{array}{l}\text { D.L. IX, 104- } \\
\text { 105: } \\
\text { O ceticismo } \\
\text { destrói a } \\
\text { própria vida. }\end{array}$ & $\begin{array}{c}\text { * Há uma } \\
\text { contradição entre } \\
\text { asserir e } \\
\text { prescrever um } \\
\text { modo de vida } \\
\text { não assertórico. } \\
\text { * Dificilmente se } \\
\text { pode imaginar } \\
\text { que conservar-se } \\
\text { ativo nas } \\
\text { investigações e } \\
\text { nos combates } \\
\text { filosóficos é } \\
\text { viver uma vida } \\
\text { feliz. }\end{array}$ \\
\hline
\end{tabular}




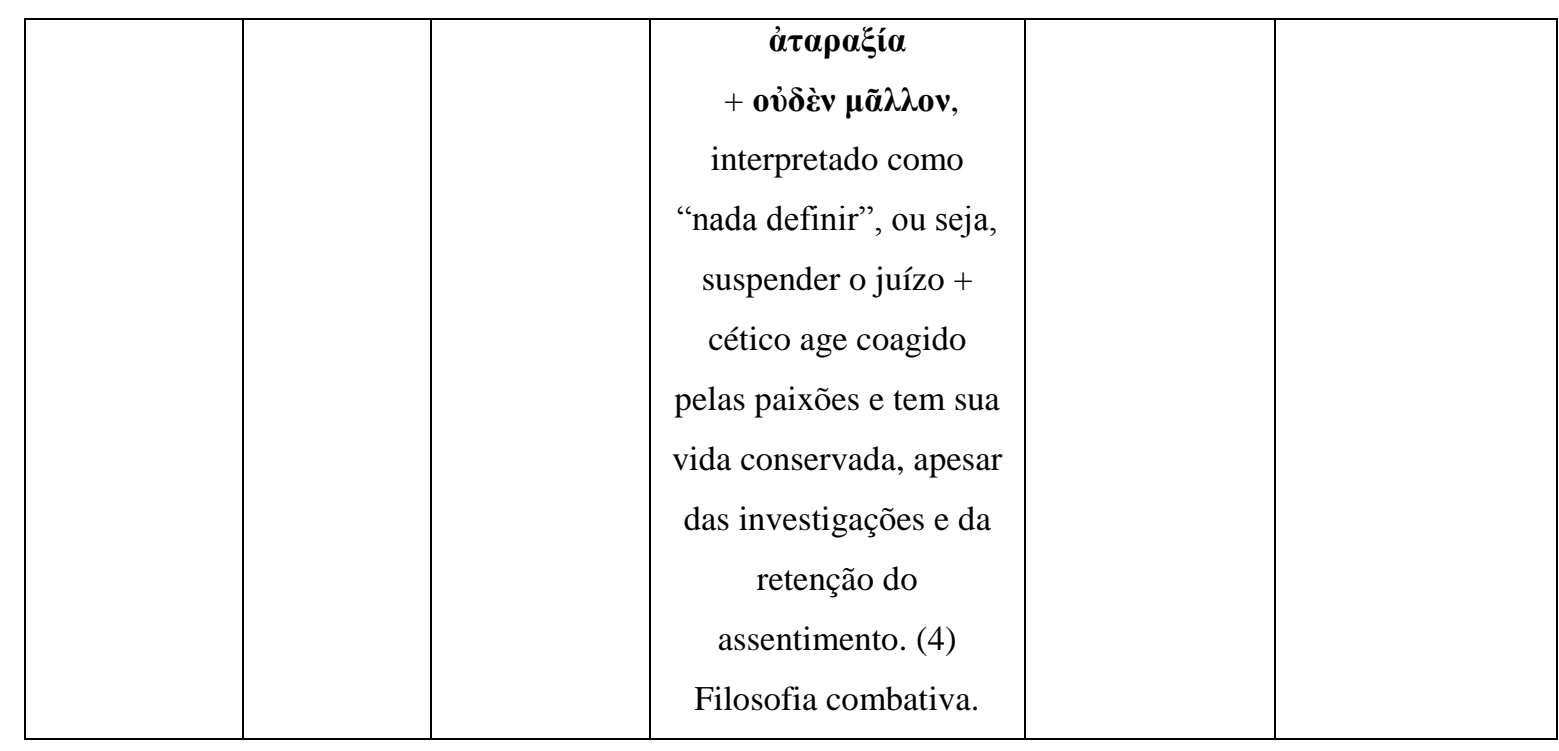

\begin{tabular}{|c|c|c|c|c|c|}
\hline Fase: & Fontes: & Quem: & Âmbitos: & Críticas: & Problemas das fontes: \\
\hline $\begin{array}{c}\text { Média } \\
\text { academia: }\end{array}$ & $\frac{\text { Timão, in: }}{\frac{\text { D.L. IV }}{\underline{33 .}}}$ & Arcesilao: & $\begin{array}{l}\text { Pirronismo como } \\
\text { atitude prática. }\end{array}$ & $\begin{array}{c}\text { Filosofia } \\
\text { quimérica: } \\
\text { platonismo + } \\
\text { pirronismo + } \\
\text { dialética } \\
\text { (Aríston de } \\
\text { Quíos, in: D.L. } \\
\text { IV, 33). }\end{array}$ & $X$ \\
\hline Idem & $\begin{array}{c}\text { Quaest. } \\
\underline{\text { Natu. }} \\
\underline{7.32 .2}\end{array}$ & Idem & $\begin{array}{l}\text { Acadêmicos } \\
\text { como os } \\
\text { verdadeiros } \\
\text { portadores do } \\
\text { pirronismo. }\end{array}$ & $\begin{array}{c}\text { Arcesilao não } \\
\text { agia conforme } \\
\text { dizia (Cleanto de } \\
\text { Assos, in: D.L. } \\
\text { VII, 171). }\end{array}$ & $\bar{X}$ \\
\hline Idem & $\frac{D . L . I V}{\underline{31}}$ & Idem & $\begin{array}{c}\text { Exercícios } \\
\text { constantes de } \\
\text { argumentação. }\end{array}$ & $\begin{array}{c}\text { Adulador da } \\
\text { turba e exibido. } \\
\text { (Timão, in: D.L. } \\
\text { IV, 42; IX, 115). }\end{array}$ & $X$ \\
\hline Idem & $\begin{array}{c}\frac{\text { Numênio, }}{\underline{\text { in: } P E .}} \\
\frac{14.6 .4-6 ;}{\underline{P . H . \mathrm{I}}} \\
\underline{232 .}\end{array}$ & Idem & $\begin{array}{c}\text { Arcesilao } \\
\text { compartilhava o } \\
\text { discurso de Pirro. }\end{array}$ & $\begin{array}{c}\text { Arcesilao } \\
\text { atribuía valor } \\
\text { positivo à } \\
\text { suspensão do } \\
\text { juízo e usava a } \\
\text { dialética como } \\
\text { método para } \\
\text { verificar os }\end{array}$ & $X$ \\
\hline
\end{tabular}




\begin{tabular}{|c|c|c|c|c|c|}
\hline & & & & $\begin{array}{c}\text { dogmas de } \\
\text { Platão (P.H. I, } \\
\text { 234). }\end{array}$ & \\
\hline Idem & $\frac{\underline{D . L . ~ I V,}}{37 ; \mathrm{IV}, 43 .}$ & Idem & $\begin{array}{c}\text { Sarcasmo e } \\
\text { belicosidade. }\end{array}$ & $X$ & $X$ \\
\hline Idem & $\frac{D e O r}{\underline{3.67 .}}$ & Idem & $\begin{array}{l}\text { Argumentava a } \\
\text { favor e contra } \\
\text { qualquer coisa. }\end{array}$ & $X$ & $\begin{array}{l}\text { * Não é possível saber } \\
\text { se defendia realmente } \\
\text { seus pontos de vista } \\
\text { particulares, ou se eles } \\
\text { surgiam sempre como } \\
\text { resultados de debates } \\
\text { ad hominem. }\end{array}$ \\
\hline Idem & $\frac{\text { Acad.pos. }}{\underline{77}}$ & Idem & $\begin{array}{c}\text { Asseriu que não } \\
\text { há impressão de } \\
\text { algo verdadeiro } \\
\text { tal que não haja } \\
\text { uma semelhante } \\
\text { de algo falso. } \\
\downarrow\end{array}$ & $X$ & $\begin{array}{l}\text { * Asserção dogmática, } \\
\text { mas somente se for } \\
\text { expressão do ponto de } \\
\text { vista de Arcesilao. Se } \\
\text { for resultado de um } \\
\text { debate ad hominem } \\
\text { provém do dogmatismo } \\
\text { estoico, tem cunho } \\
\text { dialético e não } \\
\text { necessita de uma } \\
\text { adesão derradeira, } \\
\text { somente provisória. }\end{array}$ \\
\hline Idem & $\begin{array}{l}\text { Acad.pos. } \\
\text { 84-86;91. }\end{array}$ & Idem & $\begin{array}{c}\downarrow \\
\text { As impressões } \\
\text { são indiscerníveis } \\
\text { porque os objetos } \\
\text { que as originam } \\
\text { são indiscerníveis } \\
\text { uns dos outros; ou } \\
\text { porque o sujeito } \\
\text { não tem } \\
\text { condições de } \\
\text { discernir. }\end{array}$ & $\begin{array}{c}\text { Zenão: o sábio } \\
\text { estoico tem } \\
\text { capacidade } \\
\text { discernir (Acad. } \\
\text { pos. 20,56-58). } \\
\text { Mas então ele é } \\
\text { critério de si } \\
\text { próprio e isso é } \\
\text { uma } \\
\text { circularidade } \\
\text { (SVF III, 138). } \\
\text { Duas coisas não } \\
\text { podem ser tais } \\
\text { que sejam } \\
\text { idênticas: } \\
\text { asserção não }\end{array}$ & Idem \\
\hline
\end{tabular}




\begin{tabular}{|c|c|c|c|c|c|}
\hline & & & & $\begin{array}{l}\text { evidente. Acad. } \\
\text { pos. } 50,54-56) \text {. }\end{array}$ & \\
\hline Idem & $\frac{A d v \cdot \log .}{\underline{\mathrm{I}, 157 .}}$ & Idem & $\begin{array}{c}\text { Se não é possível } \\
\text { distinguir entre as } \\
\text { impressões, o } \\
\text { sábio, uma vez } \\
\text { que não age de } \\
\text { acordo com } \\
\text { opiniões, terá que } \\
\text { recusar a assentir, } \\
\text { que é suspender o } \\
\text { juízo. }\end{array}$ & 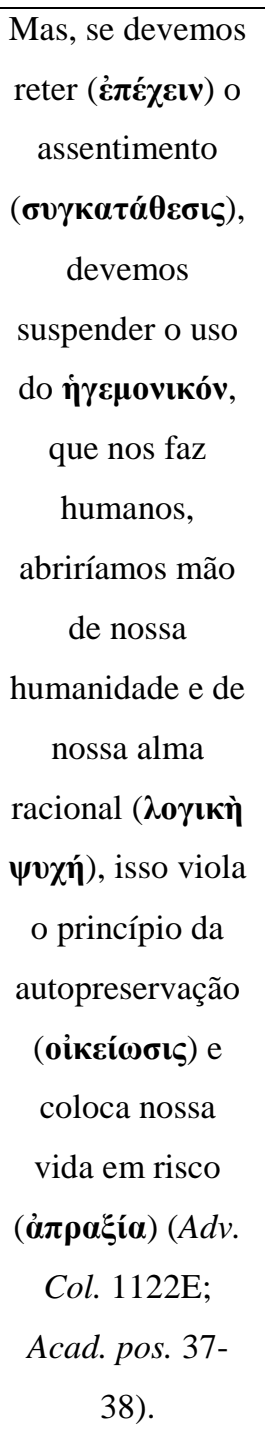 & $X$ \\
\hline Idem & $\begin{array}{c}\text { Adv. Log. } \\
\text { I, 158; } \\
\underline{A d v . C o l .} \\
\underline{1122 \mathrm{~A}-\mathrm{F} .}\end{array}$ & Idem & 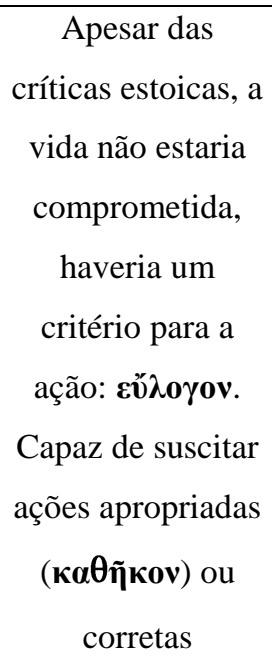 & $X$ & 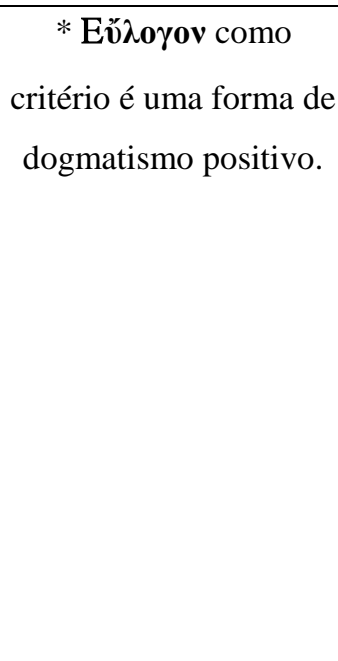 \\
\hline
\end{tabular}




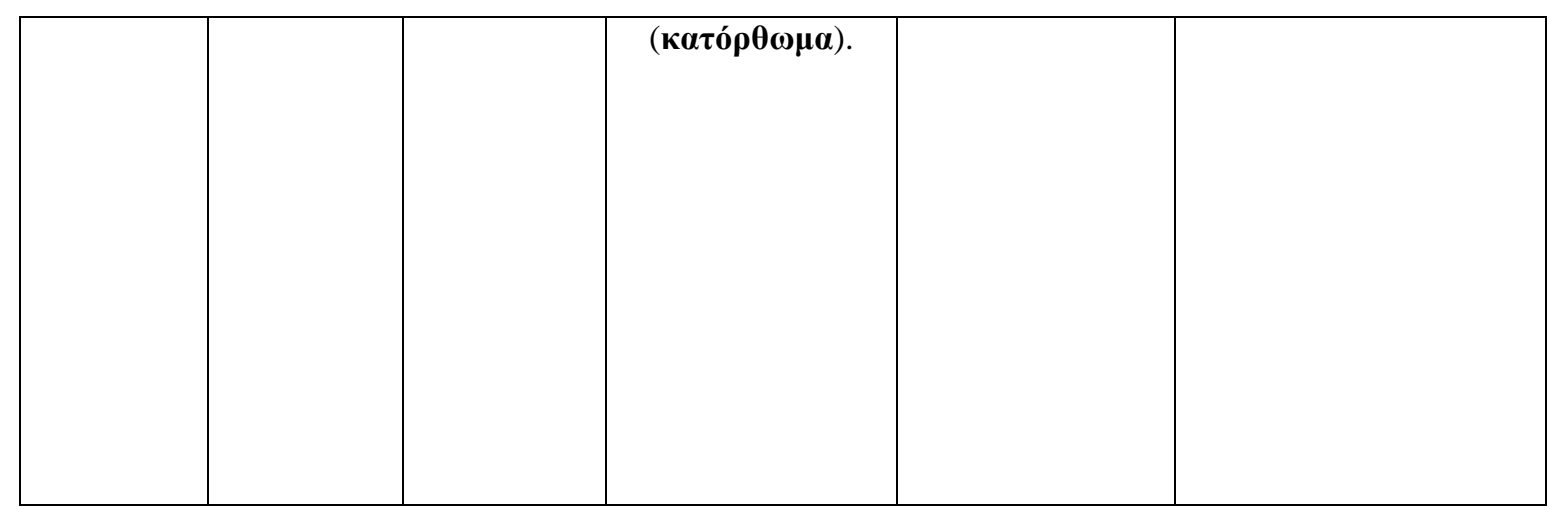

\begin{tabular}{|c|c|c|c|c|c|}
\hline Fase: & Fontes: & Quem: & Âmbitos: & Críticas: & Problemas das fontes: \\
\hline $\begin{array}{c}\text { Média } \\
\text { academia: }\end{array}$ & $\begin{array}{c}\text { Acad.pos. } \\
\underline{139}\end{array}$ & Carnéades: & $\begin{array}{c}\text { Defendia } \\
\text { quaisquer } \\
\text { posições, por } \\
\text { serem } \\
\text { igualmente } \\
\text { persuasivas. }\end{array}$ & $\mathrm{X}$ & $\begin{array}{c}\text { * Não é possível saber se } \\
\text { o que defendia eram seus } \\
\text { pontos de vista } \\
\text { particulares, ou se eram } \\
\text { posições provisórias } \\
\text { originadas em debates ad } \\
\text { hominem. }\end{array}$ \\
\hline Idem & $\frac{\text { D.L. IV, }}{\underline{62 .}}$ & Idem & $\begin{array}{l}\text { Belicosidade, } \\
\text { principalmente } \\
\text { contra os } \\
\text { estoicos, sob } \\
\text { Crisipo. }\end{array}$ & $\mathrm{X}$ & $X$ \\
\hline Idem & $\begin{array}{c}\underline{A d v . P h y .} \\
\underline{\text { I, 146-147, }} \\
\underline{151-171 .}\end{array}$ & Idem & $\begin{array}{c}\text { Ataque às } \\
\text { concepções } \\
\text { físicas estoicas: } \\
\text { deus como ser } \\
\text { vivo, eterno e } \\
\text { benevolente. }\end{array}$ & $\mathrm{X}$ & $\mathrm{X}$ \\
\hline Idem & $\begin{array}{l}\underline{A d v . P h y} . \\
\underline{\mathrm{I}, 182-184 .}\end{array}$ & Idem & $\begin{array}{c}\text { Paradoxo do } \\
\text { sorites contra a } \\
\text { quantidade } \\
\text { indeterminada de } \\
\text { deuses do } \\
\text { politeísmo. }\end{array}$ & $X$ & $\mathrm{X}$ \\
\hline Idem & $\begin{array}{l}\frac{\text { D.L.X. }}{128-129 ;} \\
\text { De Fin. } 1 .\end{array}$ & Idem & 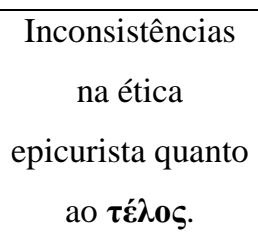 & $\mathrm{X}$ & $X$ \\
\hline
\end{tabular}




\begin{tabular}{|c|c|c|c|c|c|}
\hline Idem & $\begin{array}{c}\frac{\text { Tusc. }}{\text { 5.120; De }} \\
\frac{\text { Fin. 3.41; }}{\text { Adv. Log. }} \\
\underline{\text { I, 159. }}\end{array}$ & Idem & 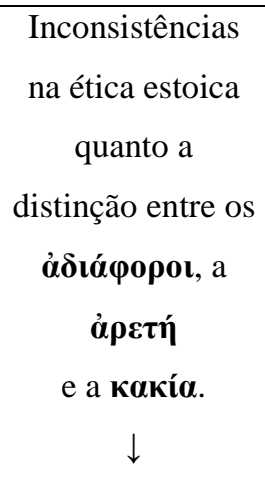 & $X$ & $X$ \\
\hline Idem & $\underline{\text { Idem }}$ & Idem & $\begin{array}{c}\text { Assim, ou o } \\
\text { estoico abre mão } \\
\text { dos bens } \\
\text { corporais } \\
\text { externos (e se } \\
\text { torna um cínico), } \\
\text { ou adere a esses } \\
\text { bens (e se torna } \\
\text { um peripatético). }\end{array}$ & $X$ & $X$ \\
\hline Idem & Idem & Idem & $\begin{array}{l}\text { O que importa } \\
\text { nas ações são } \\
\text { seus resultados } \\
\text { pragmáticos, e } \\
\text { não seus } \\
\text { pressupostos } \\
\text { teóricos. }\end{array}$ & $X$ & $X$ \\
\hline Idem & $\begin{array}{l}\underline{A d v . \log .} \\
\underline{\mathrm{I}, 159 ; P E .} \\
\underline{14.7 .15 .5 .}\end{array}$ & Idem & $\begin{array}{c}\text { Rejeição do } \\
\text { critério, tanto } \\
\text { estoico quanto } \\
\text { qualquer outro + } \\
\text { as coisas são } \\
\text { incertas, } \\
\text { podemos ser } \\
\text { enganados e } \\
\text { assentir } \\
\text { erroneamente, } \\
\text { então devemos } \\
\text { suspender o } \\
\text { juízo. } \\
\downarrow\end{array}$ & $\begin{array}{c}\text { Estoicos: a } \\
\text { impressão } \\
\text { verdadeira } \\
\text { compele ao } \\
\text { assentimento } \\
\text { (Adv. Log. I, } \\
\text { 257) + se não } \\
\text { houver critério, } \\
\text { tudo será } \\
\text { incerto (Acad. } \\
\text { pos. 32); e a } \\
\text { vida seria } \\
\text { impossível } \\
\text { (ådvvapía, in: } \\
\text { PE. 14.7.15.5- } \\
\text { 6). }\end{array}$ & $\begin{array}{l}\text { * A ação só é de fato } \\
\text { impossibilitada de } \\
\text { acordo com o ponto de } \\
\text { vista estoico do que está } \\
\text { em jogo nas ações. }\end{array}$ \\
\hline
\end{tabular}




\begin{tabular}{|c|c|c|c|c|c|}
\hline Idem & $\begin{array}{c}\frac{P E .}{14.7 .15 .5 ;} \\
\frac{\text { Acad. pos. }}{\underline{47-49 .}}\end{array}$ & Idem & $\begin{array}{l}\text { O persuasivo } \\
(\boldsymbol{\pi} \boldsymbol{\imath} \boldsymbol{\alpha} \boldsymbol{\alpha} \mathbf{v o ́}) \text { é } \\
\text { suficientemente } \\
\text { eficaz como } \\
\text { critério } \\
\text { pragmático. }\end{array}$ & $\begin{array}{c}\text { Apesar de } \\
\text { estritamente } \\
\text { pragmático, } \\
\text { esse é um } \\
\text { critério } \\
\text { dogmático, } \\
\text { como são todos } \\
\text { quando } \\
\text { assertóricos } \\
\text { (P.H. I, 230). }\end{array}$ & $X$ \\
\hline
\end{tabular}

\begin{tabular}{|c|c|c|c|c|c|}
\hline Fases: & Fontes: & Quem: & Âmbitos: & Críticas: & $\begin{array}{l}\text { Problemas } \\
\text { das fontes: }\end{array}$ \\
\hline $\begin{array}{c}\text { Média } \\
\text { academia: }\end{array}$ & $\frac{\text { D.L. IV, }}{67 .}$ & Clitômaco: & $\begin{array}{l}\text { Amplo conhecimento } \\
\text { das doutrinas } \\
\text { acadêmica, estoica e } \\
\text { peripatética + adesão } \\
\text { ao critério de } \\
\text { Carnéades: } \boldsymbol{\pi} \mathbf{\imath} \boldsymbol{\theta} \text { avóv. }\end{array}$ & $\begin{array}{l}\text { Muito prolixo } \\
\text { (Timão, in: } \\
\text { D.L. IV, 67). } \\
\text { Apesar de } \\
\text { estritamente } \\
\text { pragmático, } \\
\text { esse é um } \\
\text { critério } \\
\text { dogmático, } \\
\text { como são } \\
\text { todos quando } \\
\text { assertóricos } \\
\text { (P.H. I, 230). }\end{array}$ & $\mathrm{X}$ \\
\hline Nova academia: & $\begin{array}{c}\underline{P E .} \\
14.9 .1-2 .\end{array}$ & $\begin{array}{l}\text { Filo de } \\
\text { Larissa: }\end{array}$ & $X$ & $\begin{array}{l}\text { Rejeição da } \\
\dot{\varepsilon} \boldsymbol{\varepsilon} \mathbf{0} \boldsymbol{\chi} \tilde{\eta} .\end{array}$ & $\begin{array}{c}\text { * A mitigação } \\
\text { da suspensão } \\
\text { pode envolver } \\
\text { a adesão } \\
\text { parcial a um } \\
\text { dogmatismo. } \\
\downarrow\end{array}$ \\
\hline Idem & $\frac{P . H . \mathrm{I},}{\underline{220 .}}$ & Idem & $X$ & $\begin{array}{c}\text { Os objetos } \\
\text { devem ser } \\
\text { naturalmente } \\
\text { apreensíveis, } \\
\text { ainda que não } \\
\text { de acordo com }\end{array}$ & $\begin{array}{c}* \\
\text { Dogmatismo } \\
\text { positivo. }\end{array}$ \\
\hline
\end{tabular}




\begin{tabular}{|c|c|c|c|c|c|}
\hline & & & & $\begin{array}{l}\text { o critério } \\
\text { estoico. }\end{array}$ & \\
\hline $\begin{array}{c}\text { Cisão } \\
\text { (alinhamento } \\
\text { com o } \\
\text { estoicismo): }\end{array}$ & $\begin{array}{c}\text { Acad.pri. } \\
\underline{17-18 .} .\end{array}$ & $\begin{array}{l}\text { Antíoco de } \\
\text { Ascalão: }\end{array}$ & X & $\begin{array}{c}\text { Traição à } \\
\text { filosofia de } \\
\text { Platão. }\end{array}$ & $\begin{array}{c}\text { *Dogmatismo } \\
\text { positivo: } \\
\text { adesão ao } \\
\text { estoicismo. }\end{array}$ \\
\hline Idem & $\frac{\text { Acad.pos. }}{\underline{18-31 .}}$ & Idem & $X$ & $\begin{array}{c}\text { Ecletismo } \\
\text { como forma } \\
\text { de diluir as } \\
\text { divergências. }\end{array}$ & $X$ \\
\hline $\begin{array}{c}\text { Cisão } \\
\text { (reavivamento } \\
\text { do pirronismo): }\end{array}$ & $\frac{\underline{B i b .}}{\frac{170 \mathrm{a} 14-}{17 .}}$ & $\begin{array}{l}\text { Enesidemo } \\
\text { de Cnossos: }\end{array}$ & $\begin{array}{c}\text { Ruptura com o } \\
\text { dogmatismo da nova } \\
\text { academia e acusação } \\
\text { de que os debates } \\
\text { entre Filo e Antíoco } \\
\text { de Ascalão e os } \\
\text { demais estoicos não } \\
\text { passavam de estoicos } \\
\text { lutando contra } \\
\text { estoicos. }\end{array}$ & $\mathrm{X}$ & $X$ \\
\hline Idem & $\frac{\underline{\text { D.L. IX. }}}{\underline{116 .}}$ & Idem & $\begin{array}{c}\text { Escreveu 'Discursos } \\
\text { Pirrônicos'. } \\
\downarrow\end{array}$ & $\begin{array}{c}\text { Enesidemo era } \\
\text { dogmático ao } \\
\text { considerar que } \\
\text { o ceticismo } \\
\text { era uma via } \\
\text { para o } \\
\text { heraclitismo } \\
\text { (Adv. Log. I, } \\
\text { 349; Adv. Phy. } \\
\text { I, 337, e II } \\
\text { 216, 233; P.H. } \\
\text { I, 210.) }\end{array}$ & $\mathrm{X}$ \\
\hline Idem & $\begin{array}{l}\text { P.H. I, 36- } \\
164,180- \\
\underline{187 ; \text { D.L. }} \\
\underline{\mathrm{IX}, 79-88,} \\
\underline{98-99 .}\end{array}$ & Idem & $\begin{array}{c}\text { Criação (ou } \\
\text { sistematização?) dos } \\
10 \text { tropos que } \\
\text { apontam que há } \\
\text { situações em que o } \\
\text { julgamento é } \\
\text { impossível, quando: } \\
\text { (a) o sujeito que julga }\end{array}$ & $X$ & $\mathrm{X}$ \\
\hline
\end{tabular}




\begin{tabular}{|c|c|c|c|c|c|}
\hline & & & $\begin{array}{l}\text { não tem condições de } \\
\text { fazê-lo; (b) o objeto } \\
\text { não tem condições de } \\
\text { ser julgado; (c) } \\
\text { ambos } \\
\text { simultaneamente + } 8 \\
\text { tropos contra a } \\
\text { causalidade. }\end{array}$ & & \\
\hline Idem & $\begin{array}{l}\underline{\text { D.L. IX, }} \\
\underline{88-90 ;} \\
\underline{P . H . \mathrm{I}} \\
\underline{164-178 .}\end{array}$ & Agripa: & $\begin{array}{l}\text { Cinco tropos, com a } \\
\text { exceção de um, } \\
\text { dirigidos às formas } \\
\text { dos argumentos } \\
\text { dogmáticos, e não } \\
\text { aos seus conteúdos. }\end{array}$ & $X$ & $X$ \\
\hline
\end{tabular}




\begin{tabular}{|c|c|c|c|c|c|}
\hline $\begin{array}{l}\text { Infiltração nas } \\
\text { discussões } \\
\text { médicas: }\end{array}$ & $\frac{\text { D.L. IX }}{\underline{116 .}}$ & $\begin{array}{c}\text { Zeuxipos, } \\
\text { Zeuxis, } \\
\text { Antíoco de } \\
\text { Laodicéia, } \\
\text { Heródoto } \\
\text { de Tarso e } \\
\text { Saturnino: }\end{array}$ & 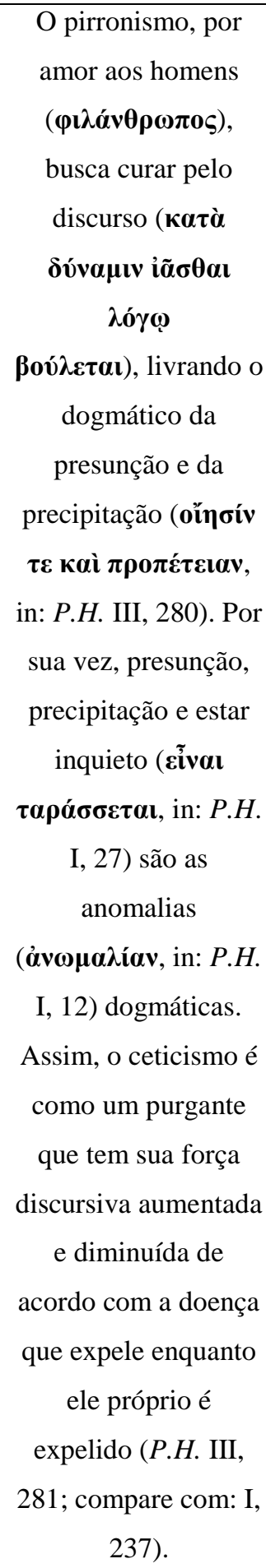 & $X$ & $X$ \\
\hline
\end{tabular}

\subsection{Tábua cronológica dos principais pensadores Antigos citados e suas filiações filosóficas}
Abaixo, para facilitar a localização temporal dos pensadores Antigos que citamos
e também com vistas a precisarmos suas linhagens filosóficas, fornecemos uma 
tábua cronológica que pode servir como apoio didático e elucidativo. Dessa forma, apresentamos as sucessões dos filósofos das escolas ou condutas filosóficas mais recorrentes em nosso texto.

\section{$\underline{\text { Academia }}$ \\ 387: Platão funda a academia \\ 347: Platão morre e é sucedido por Espeusipo 339: Espeusipo} morre e é sucedido por Xenócrates

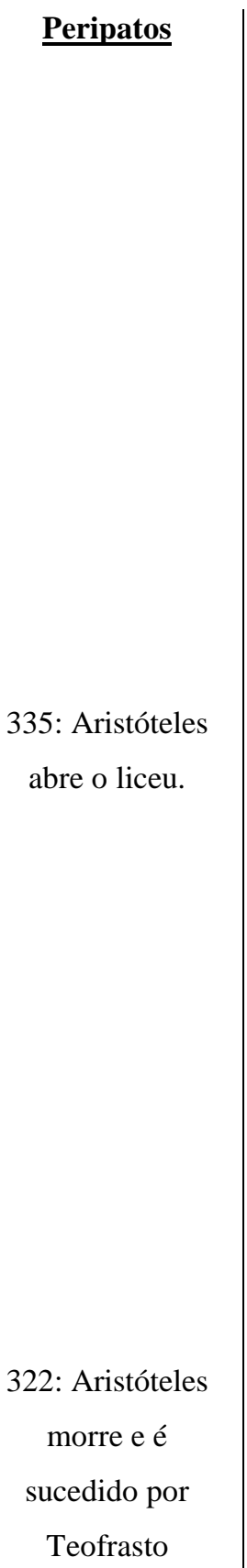

c. 325: Timão de

Fliunte nasce

(?): Euríloco,

Hecateu/Ascânio de Abdera,

Numênio,

Nausífanes e Filo de Atenas estudam com

Pirro
Estoicos

341: Epicuro nasce

c. 328: Epicuro estuda com o platonista Panfilo de Samos

c. 321: Epicuro estuda com o pirrônico/atomista 


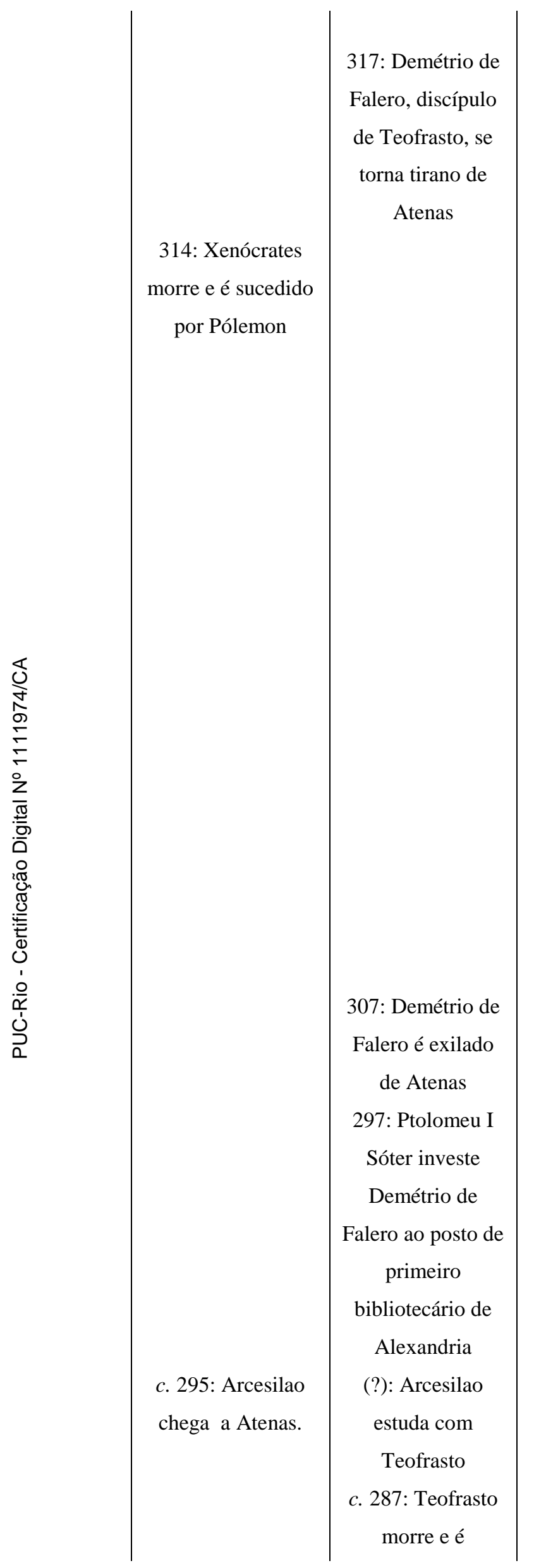

312: Vindo de

Cítio, Zenão

chega a Atenas, e nos anos seguintes estuda com Crates (cínico), Estilpo (megárico),

Pólemon (acadêmico) e Diodoro Cronos (dialético)

\section{Nausífanes}

311-310: Epicuro abre escolas em

Mitilene e

Lampsaco 307: Epicuro funda o jardim em Atenas 

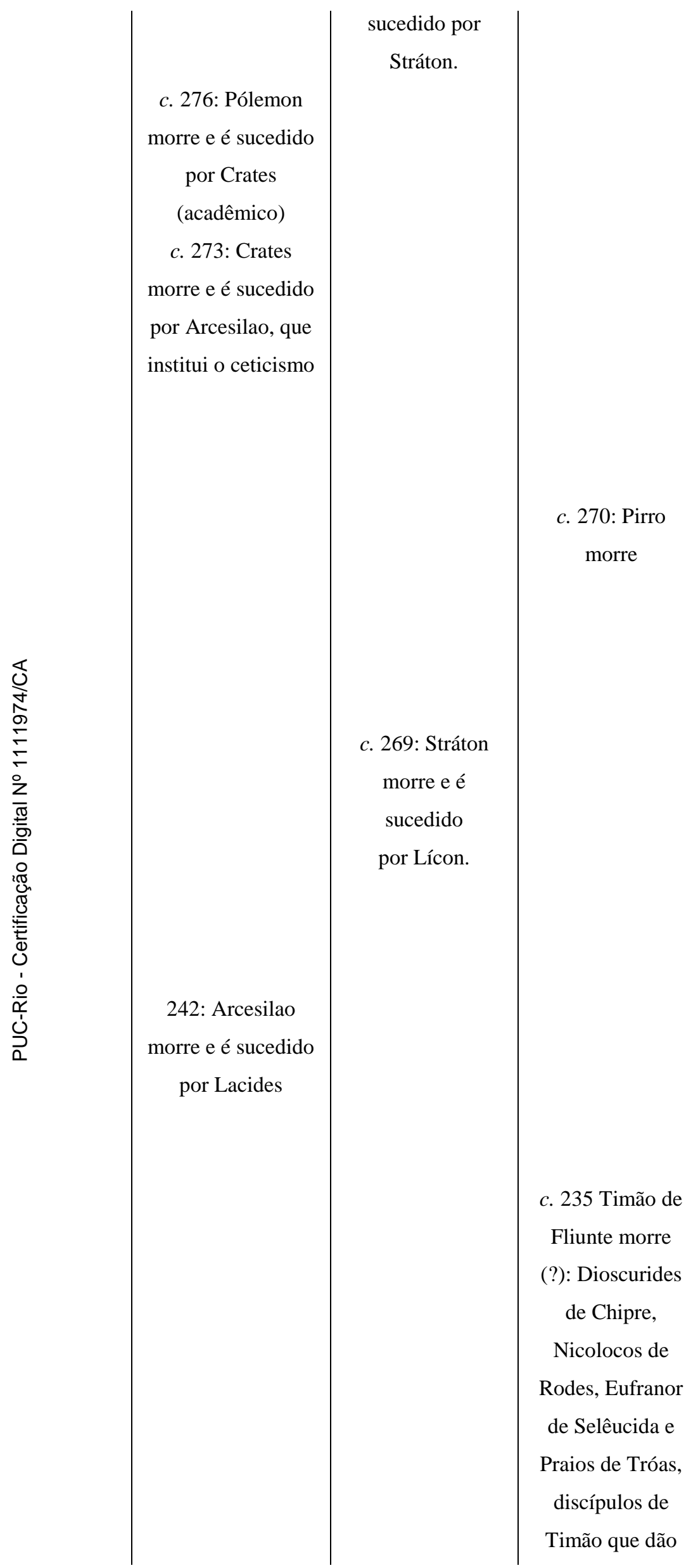

fl.c. 310-260:

Colotes

271: Epicuro morre e é sucedido por

Hemarco

c. 235 Timão de

Fliunte morre

(?): Dioscurides de Chipre,

Nicolocos de

Rodes, Eufranor de Selêucida e

Praios de Tróas, discípulos de Timão que dão fl. c. 270-250:

Aríston de Quíos; fl. c. 280-243:

Perseu de Cítio;

(?): Herilo de

Cartago

262: Zenão morre e é sucedido por

Cleanto

fl. c. 240-210:

Sfairos

c. 232: Cleanto

morre e é sucedido por

Crisipo 
c. 219 Carnéades

nasce

(?): Carnéades se

torna

líder da academia

155: Carnéades na

Embaixada de

Roma com

o peripatético

Critolau

e o estoico

Diógenes da

Babilônia c. 181- (?): Sátiro

se torna líder o

liceu

(?): Ptolomeu de

Cirene estuda

com Eubolos

155: Critolau, à

época líder do

liceu, na

Embaixada de

Roma com o

acadêmico

Carnéades e o

estoico Diógenes

da Babilônia seguimento ao

pirronismo

(?): Eubolos

estuda com

Eufranor de

Selêucida

c. 206: Crisipo

morre e é

sucedido por

Zenão

de Tarsos

55: Diógenes da

Babilônia na

Embaixada de

Roma com o

peripatético

Critolau e o

acadêmico

Carnéades

(?): Zenão de

Tarsos morre e é sucedido por

Diógenes

da Babilônia

c. 152: Diógenes

morre e é

sucedido por

Antipater de

Tarsos 


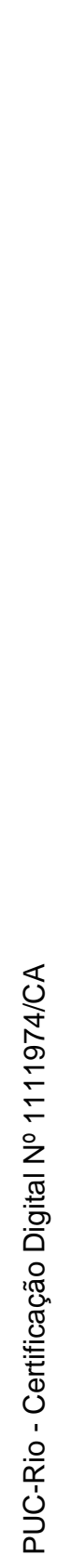

137: Carnéades

retira-se por motivo

de doença

129: Carnéades morre

c. 128: Clitômaco se torna líder da academia

c. 110: Clitômaco morre e é sucedido por Filo de

Larissa

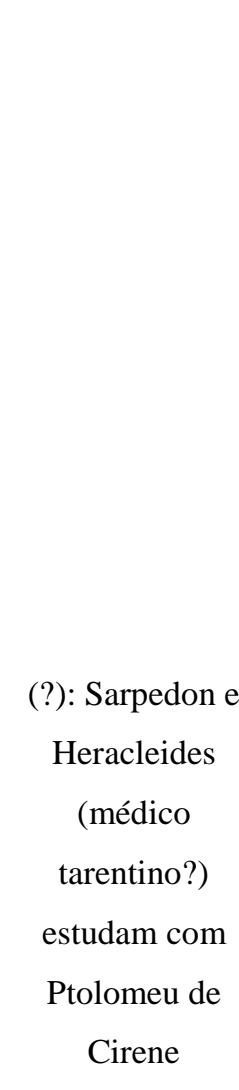

c. 110: Diodoro de Tiro lidera o liceu e tenta alinhar o aristotelismo com o estoicismo e o epicurismo (?): Cratipo de Pérgamo lidera o liceu c. 100:

fl. c. 150:

Apolodoro torna a escola epicurista a mais vigorosa de Atenas, vindo a ser por isso apelidado de "tirano do jardim"

c. 129: Antipater morre e é sucedido por

Panécio

109: Panécio

morre

(?): Mnesarco e

Dardano

compartilham a liderança da Stoá

Posidônio, 135-51
Zenão de Sídon, $c$.

155-c. 75 
c. 90: Antíoco de Ascalão rompe para

Fundar a velha academia c. 89: Filo abandona Atenas devido às instabilidades políticas reavivamento do aristotelismo

Cnossos estuda
com o pirrônico Heracleides c. 90-80: (provavelmente) Enesidemo rompe com a academia e revive o 'pirronismo'

(?): Zeuxipos de Cnossos estuda com Enesidemo

c. 75: Boethus de Sídon nasce

$$
\text { fl. c. } 60 \text { : }
$$

Andrônico de

Rodes lidera o

liceu

(?): Boethus de

Sídon comenta as

'Categorias', de Aristóteles

(?): Zeuxis (líder da célebre escola herofiliana de medicina?) estuda com Zeuxipos e adere à conduta pirrônica 95-c. 46:

Antipater de Tiro, contemporâneo de Catão, "o jovem" fl. c. 80- 45:

Filodemo de

Gadara

78: Cícero ouve as palestras de Posidônio

(?): Demétrio

Gadara
Lacon, mais jovem contemporâneo de Zenão de Sídon c. 55: Lucrécio escreve 'De rerum natura' 
45- 44: maior parte

dos

trabalhos

filosóficos de

Cícero escrita

43: morte de

Cícero
(?): Aristócles de Messênia

10: morte de

Boethus de Sídon

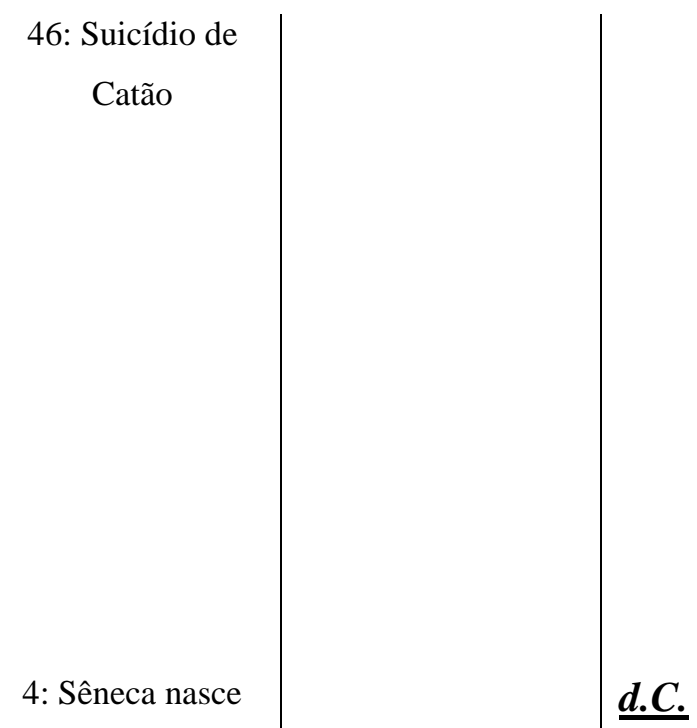

(?): Antíoco de

Laodicéia estuda com Zeuxis

(?): Agripa

50: Cornuto

ensina em Roma

65: suicídio de

Sêneca

66: Musônio

Rufo é expulso de Roma por Nero

71: Vespasiano

expulsa os

filósofos de

Roma, mas isenta

Musônio Rufo

95: Domitiano

expulsa os

filósofos de

Roma, inclusive

Epicteto

fl. c. 80:

Menodoto de

Nicomédia,

médico empírico

e pirrônico 
c. 100- c. 150:

Aspásio comenta

'De

Interpretatione',

'Física',

'Metafísica',

'Categorias' e a

'Ética a

Nicômaco', de

Aristóteles

(?): Adrasto de

Afrodísias

fl. c. 200:

Alexandre de

Afrodísias fl. c. 120: Teodás

de Laodicéia

de Epicteto

fl. c. 120 :

Hierócles de

Magnésia

130: Morte de

Epicteto

(?): o médico

Teodósio escreve seus 'Capítulos

céticos'

fl. c. 150-180:

Heródoto de

Tarsos, professor

de Sexto

Empírico

176: Marco

Aurélio funda quatro cadeiras de filosofia em

Atenas.

180: Morte de Marco Aurélio c. fim de II d.C.:

Diógenes de

Oenoanda grava a doutrina de Epicuro nas muralhas de sua cidade fl. c. 200: Sexto

Empírico 